\title{
Pressklipp om
}

Afghanistan

Maj-Juni1998

Årgång 10
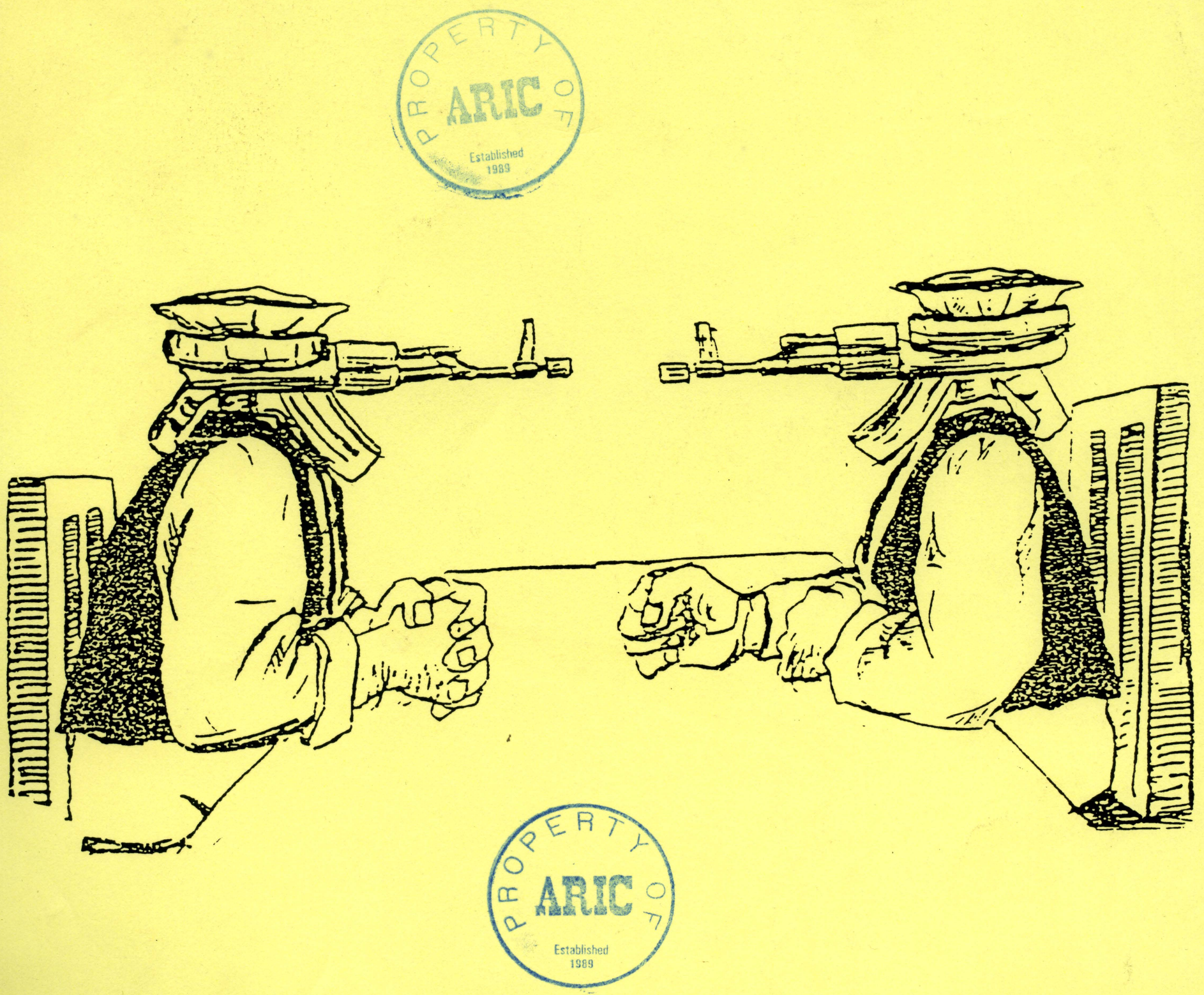

\section{PRESSKLIPP OM AFGHANISTAN}

$\square$ är ett samarbetsprojekt mellan Svenska Afghanistankommittén (SAK) och Afghanistankomiteen i Norge (AiN). $\square$ utges varannan månad som en nyhetsservice för SAKs och AiNs medlemmar, lokalkommittéer och styrelser. $\square$ detta nummer är sammanställt och redigerat av Börje Almqvist och Peter Hjukström. $\square$ pressklipp till kommande nummer mottages tacksamt från läsekretsen till adress: Svenska Afghanistankommittén, Sturegatan 16, 11436 STOCKHOLM, SVERIGE (Märk kuvertet med "Pressklipp"). $\square$ prenumerationspriset för 1998 är 250 kronor och inbetalas på pg 6423 90-9, Svenska Afghanistankommittén. Notera på inbetalningskortet att betalningen avser prenumeration på "Pressklipp". 

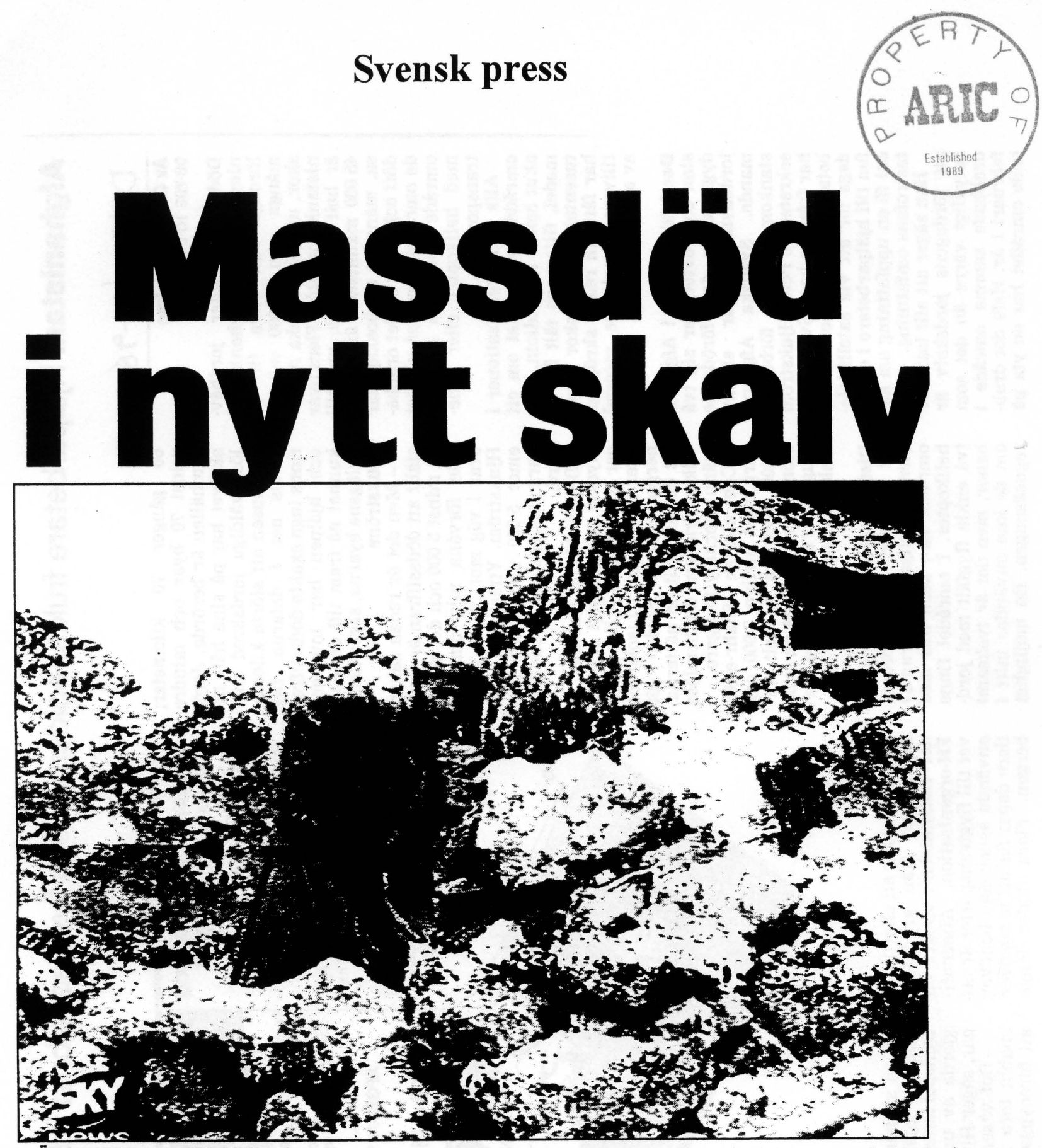

DÖDSSIFFRAN STIGER. Minst 3000 , kanske uppemot 5000 människor omkom i lördagens jordbävning $i$ Afghanistan, som mätte 7,1 pá Rlchterskalan. Skalvet är det andra som drabbat omrádet pá kort tid.

\section{Hundratals byar utplånade i Afghanistan}

\section{Expressen $1 / 6-98$}

Minst 3000 människor do dades. Mànga fler kan lig-

ga begravda under sina hus.

Flygbilderna visar hur

jordbävningen utplànat he la byar I bergen I norra Afghanistan.

Det kraftiga skalvet I lördags mätte 7,1 pả Rlchterskalan. Det var det andra som drabbat omradet sedan februari.

Dả dröjde det tio dagar innan mvärlden forst omfattning - minst $4000 \mathrm{dog}$ och hjälp kunde komma fram. Beredskapen är bättre den här gången.

Det finns lager av medicin och andra hjälpmedel i Pakistan och Afghanistan, och mer zabad den stad där närmaste flygplats finns.

Fem dagar med åsna

Från Faizabad tar det fem dagar med häst eller åsna till de gar med hast eller asna till de drabbade vaglosa omrádena 70 dra
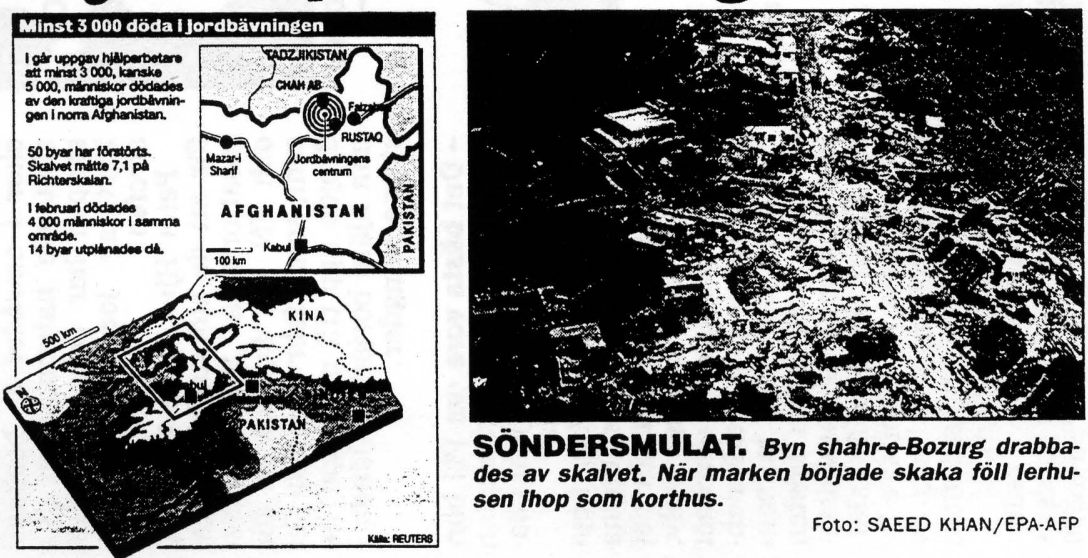

SÖNDERSMULAT. Byn shahr--Bozurg drabbades av skalvet. När marken började skaka föll lerhusen lhop som korthus.

Foto: SAEED KHAN/EPA-AFP

Den svenska Afghanistankommitténs förbundssekreterare Peter Hjukström, som i går hade kontakt med Afghanistan sa att upp till 100 byar kan ha utplånats helt och att det kan ha krävts många fler dödsoffer än efter skalvet i februar

Hälften av de 60000 invảnar na i de avlägsna bergstraktern i de báda provinserna beraknas vara hemlösa. Det är en besvärlig terräng för hjälparbetarna. Bergen stupar brant, och husen, byggda av soltorkad lera, kan inte motstá skakningar och jordskred, utan rasar ner i daarna.

Xverlevande flyr omradet FN och andra hjälporganis kare utan gränser försöker nu bist med framför allt medici nen skydd mat och vatten ner. Men skydd, mat och vatten börjat fly fràn området. Flera efterskalv kunde kännas i gả Området är ett starkt fäste för den antitalibanska gerillan Jamiat-e-Islaami, JI, som leds av den forre afghanske presiden ten Burhanuddin Rabban 


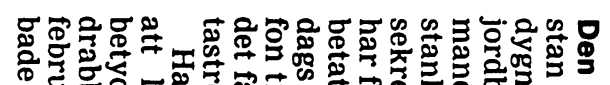
옥을

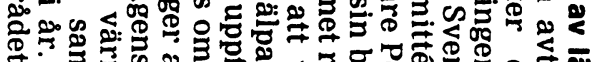

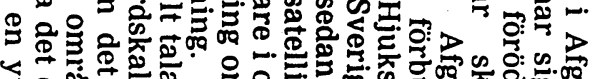

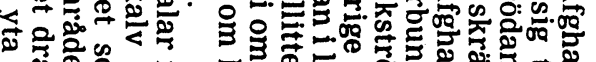

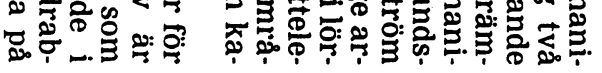
ㄱ..

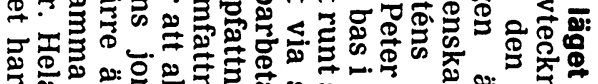
잉
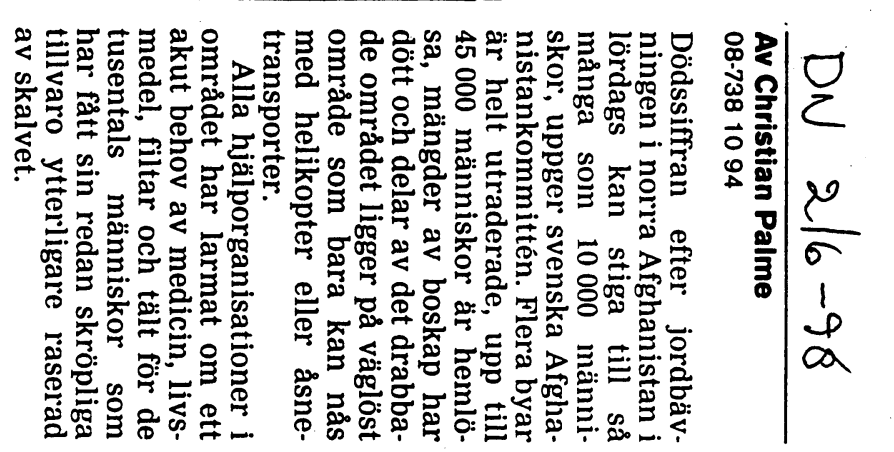

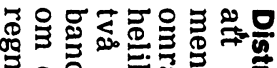
क⿻ 政

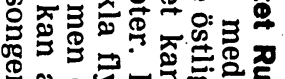
\% 떤

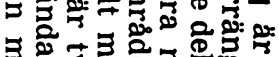

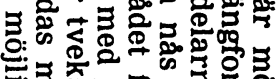

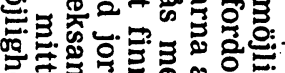

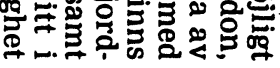

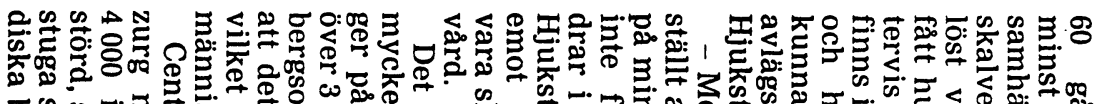

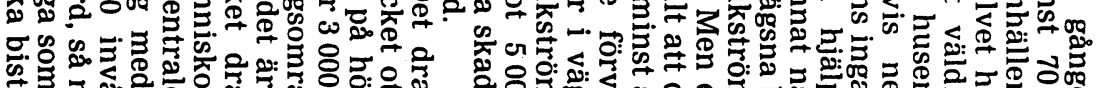

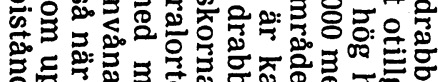

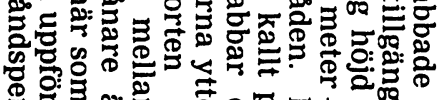

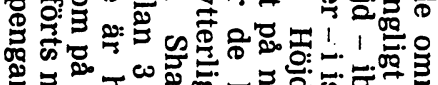

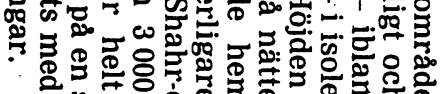

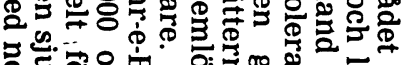

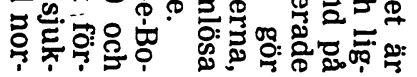

赔8

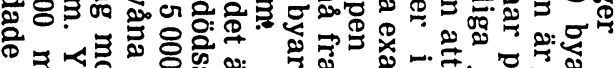

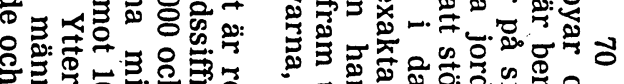

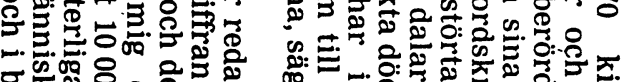

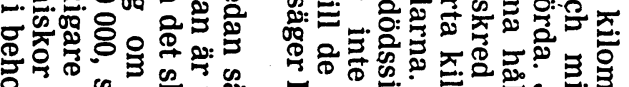

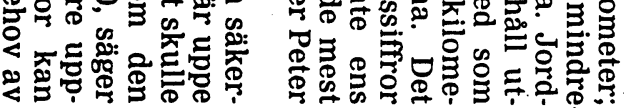

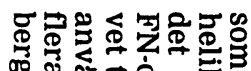

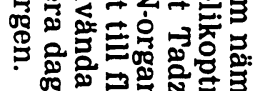

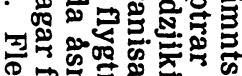

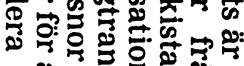

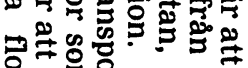

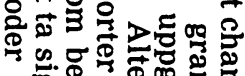

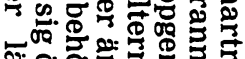

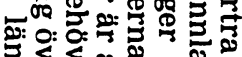

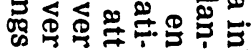

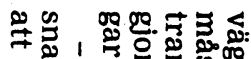

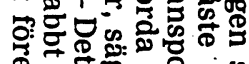

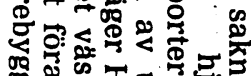

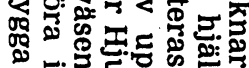

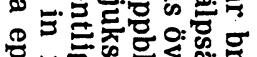
등.

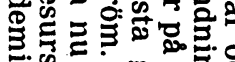

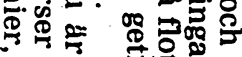

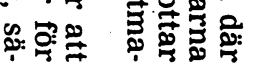

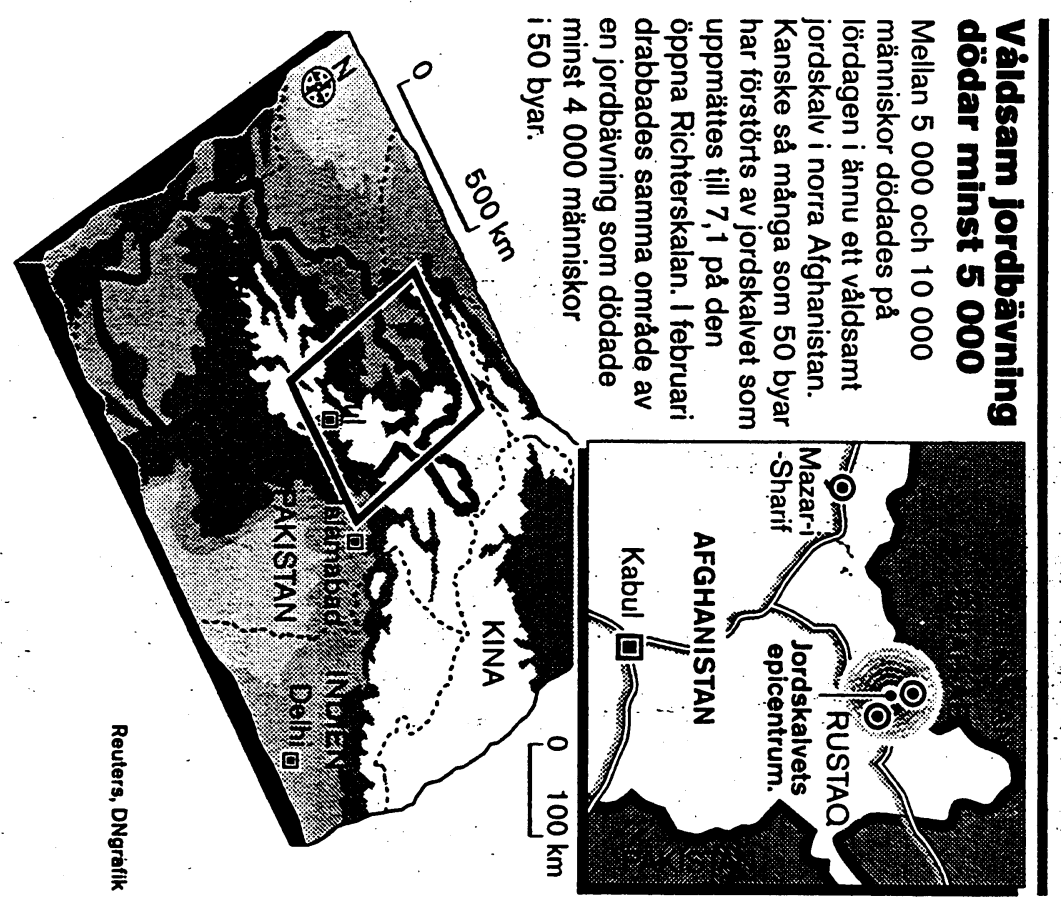

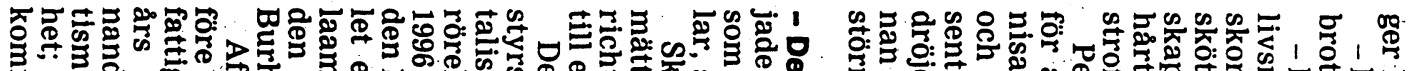

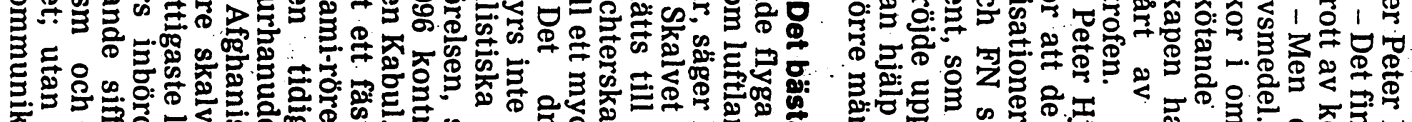

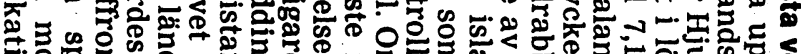
응

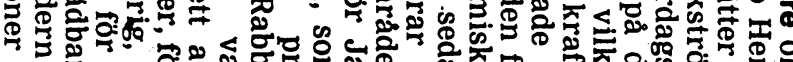

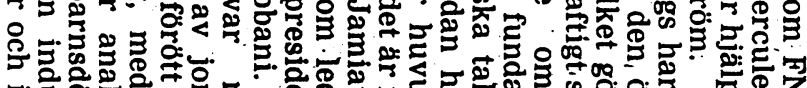

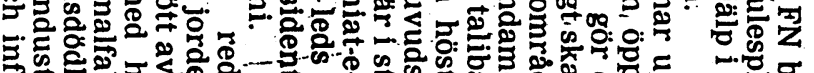

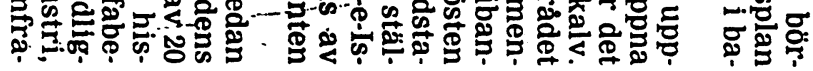

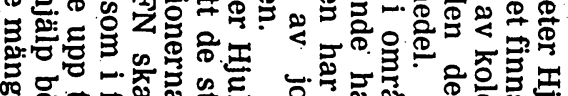

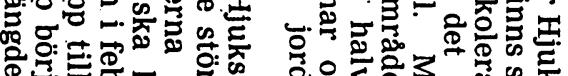

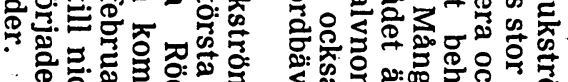

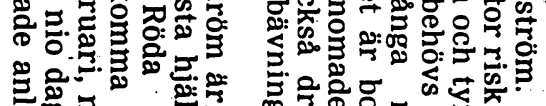

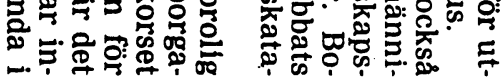

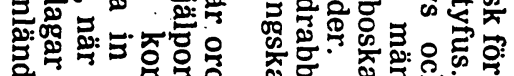
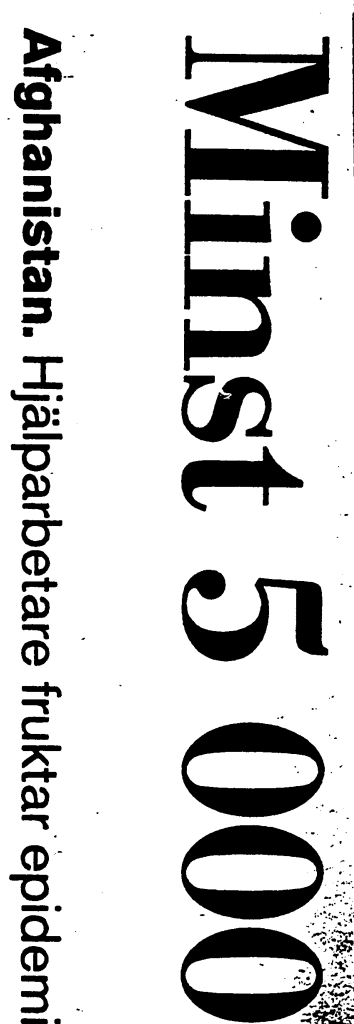

$\overline{0}$

웅
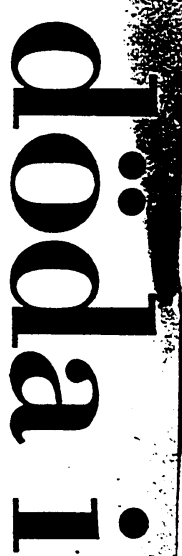

$\stackrel{+1}{0}$

올

פั:

ติำ.

ब⿳亠口冋口

$\frac{\text { 일 }}{3}$

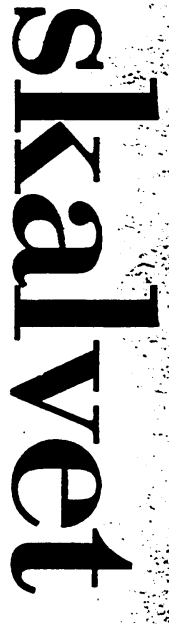




\section{Tusentals omkom i Afghanistan}

\section{Jordbävning förstörde omkring 70 byar och gjorde 45000 personer hemlösa}

\section{Simílexds posten NEWDELHI (TT)}

Hela byar har begravts $i$

Afghanistan under nedfal-

lande bergssidor. Hus har

försvunnit i djupa raviner

och mängder av samhällen

ligger i grus, rapporterade

bistảndsorganisationer från

landet pả màndagen.

Hjälpsändningar flögs in under mảndagen men var ändả långt ifrán de drabbade byarmed helikoptrar, som bara kan flyga i bra väder. Alternativet är flera dagars frakt med häst eller ásna.

Omkring 4000 människor på Afghanistans landsbygd befaras ha omkommit i skalvet.

Svenska Afghanistankommittén, med lảng erfarenhet av hjälpverksamhet i omrádet, startade pá mảndagen en insamling till jordbävningsoffren. Kommitténs forbundssekreterare Peter Hjukström skrev i ett pressmeddelande att kommittén "haft en omfattande hjälporganisation $i$ arbete sedan jordbävningen inträffade klockan 10.50 i lördags morse".

- Sedan i gár for vi in ytterligare resurser i katastrofzonen. - För att kunna mobilisera maximala resurser for hjälp-
2) $6-98$

arbetet öppnar vi nu vảr in samling Svenska Afghanistan hjälpen, postgiro 9007 80-8.

FN upprättade en luftbro med materiel. FN-planen lyfte i Pakistan och flög mat och filtar till Faizabad, huvudstad provinsen Vadakhshar, rapporterade DPA. Pakistan flög samtidigt medicin och tält till staden Mazar-i Sharif väster om skalvområdet.

\section{Utplånade}

Den allians av miliser som kontrollerar norra Afghanistan bedömde att minst 5000 människor omkommit. FN: samordnare for Afghanistan Alfredo Witschi-Cestari, sade efter ett besök $i$ området att for störelsen var mycket värre än efter skalvet i februari, då 4000 dödades.

- Hela hus har störtat ner i dalar, sade han. Vi såg ett par byar som utplảnats belt men det finns antagligen fler, sade Witschi-Cestari enligt Reuters.

Chris Teirlinck från Läkare utan gränser sade i Mazar-iSharif att vädret avgör hur snabbt hjälpen kan nả byarna. Fem helikoptrar är tillgängliga men kan bara flyga upp i cergen när det inte regnar ler är dimma.
Enligt Teirlinck sitter mánga människor som for lamade utanfor sina hoprasade hem. Andra ger sig av for att söka mat och vatten.

Lördagens jordbävning mättill 71 i Riching kraftigare än den i februari samma provinser.

Enligt Röda korsets uppskattning har 70 byar forstört och 45000 människor blivit hemlösa.

Det viktigaste är enligt hjälparbetarna att behandla tusentals skadade.

\section{Sjukvárd}

De närmaste tvá-tre dagarma kommer vi att koncentrera oss pá sjukvảrd, sade Svante Yngrot frản Internationella rödakorskommittén.

Kliniker håller pá att inrättas i de tre värst drabbade omrádena, där efterskalv känns då och då.

Yngrot sade att de ryska helikoptrarna av typ Mi8 kan göra 15 turer per dag.

- Hur det går beror helt pá väder och bränsletillgång.

Andra fasen i arbetet blir att skicka ut tält, filtar, plastdukar och vattendunkar. Materielet tornar redan upp sig på landningsbanorna i Faizabad och Mazar-i-Sharif.

\section{Afghanistankommittén startar insamling}

STOCKHOLM (TT)

Svenska Afghanistankommittén beslutade pả mảndagen att starta en nationel insamling till stöd för offren i helgens jordbävning i nordöstra Afghanistan.

Kommittén har redan folk i omrädet men vad som saknas är pengar.

- Vi har en mycket stark närvaro i de drabbade omrádenasched and of

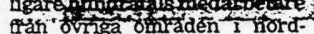
östra Afghanistan. säger kom. mitténs förbundssekretare Peter Hjukström. - Vad som kan begränsa nödvändiga och snabba insatser är brist på pengar. Erfarenheterna frản jordbävningen i februari i år visade att det är de lokalt mobiliserade resurser na som var helt avgörande un der de tio forsta dagarna efter katastrofen. Situationen är licadan i dag, säger han.

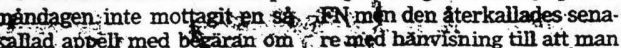

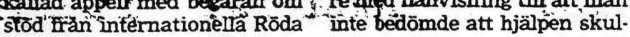
korset. le hinna fram.

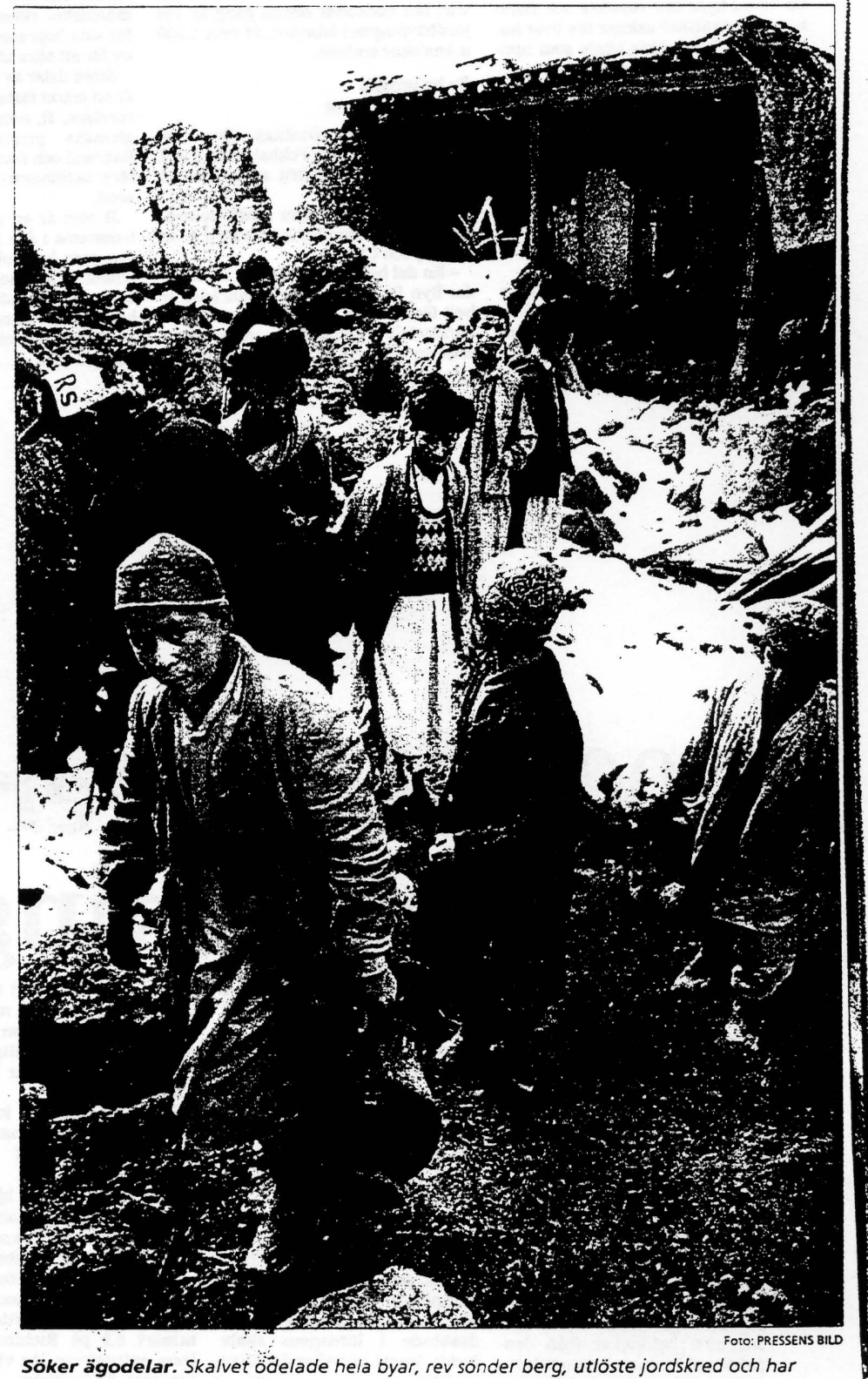

Säker agodelar. Skalvet öde 


\section{Svårt för hjälpen att nå fram}

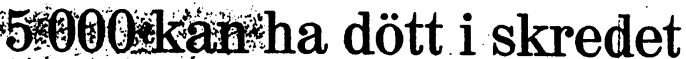

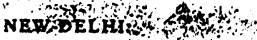

Hela byar har begravts

i Afghanistan under ned-

fallande bergssidor. Hus

har försvunnit i djupa

raviner och mängder av

samhällen ligger i grus.

II GP 2/6-98

Ett 70-tal byar har raserats och tiotusentals människor saknar tak över huvudet efter lördagens skalv som uppmättes till 7,0 pá Richterskalan.

Minst 5000 människor pá Afghanistans landsbygd befaras ha omkom mit.

FN har upprastat en luftbro med materiel. FN-planen lyfte i Pakistan och flög mat och filtar till Faizabad, hurud stad i provinsen Vadakhshar.

Hellkopter

oller àsnor

Hjälpsändningarna är ändå långt ifrản de drabbade byarna. Allt máste tas upp i bergen med helikoptrar, som bara kan flyga i bra väder.

ha forsvunnit helt

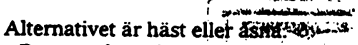
- Det tar fem dagar att ta sig till Shahr-e-Bozurg frán den närmaste staden Faizabad med häst eller ásna. Det finns inga vägar som förbinder omr det med omvärlden, sades $i$ ett uttalan de frán FN:s samordnare av humanitărt stód till Afghanistan.

Staden Shah-e-Bozurg i provinsen Badakhshar har drabbats särskilt hår och minst 2800 människor omfrom bara där.

Stickprov frán de fả byar dàr läget ăr känt visar att det kan ha krävts avsevärt fler dödsoffer denna gáng än vid jordbävningen i februari, då över 5000 människor omkom

\section{En by uppges}

Bara $i$ byarna Dashtak Ulya med 2688 invánare och Pekhab med 1708 berăknas drygt hálften av invảnarna ha omkommit.

Till de omráden som drabbats svås rast hör förutom Shahr-e-Bozurg även

Rustaq och Chah Ab. - En del byar har blivit helt utplånade. Byn Dashtaq i Rustaq-omrảdet är hundratals människor omkommit. sade en källa vid en hjälporganisation.

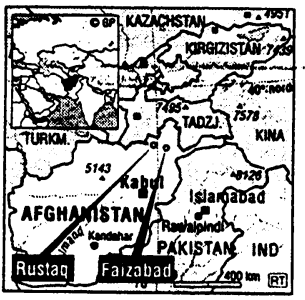

Epidemier väntas i området

Dödssiffran stiger varje timme i Afghanistans katastrofområde. Hjälporganisationer befarar att jordbävningen ska följas av svåra epidemier bland de överlevande.

Överlevande har börjat att fly frản av MONICA SAHLBACK de drabbade områdena för att fá mat, 031-624000

vatten och tak over huvudet Mringa människor sitter som förlamade utan för sina hoprasade hem. Andra ger si av för att söka mat och vatten.

- Folk mảste ha vatten och risken

stor att de dricker vatten som har runnit genom förruttnade likmassor. Det är ett starkt fïste för Jamiatte omradet kan innebära att epidemier sprids som ar ett starkt faste for Jamiat-e- Islaami- en löpeld, säger Peter Hjukström, förrörelsen, JI, som leds av den förre af- bundssekreterare för Svenska Afghaghanske presidenten Burhanuddin nistankommittén.

tansen att hitta överlevande i rastäe befalhavare Ahmed Shaha Ma- massorna är minimal redan efter 48

JI som är en av de viktigaste medlemmarna i den anti-talibanska alliansen som kontrollerar norra delar av mentalistiska talibanrörelsen som be mërtalistiska talibanrörelsen som bedelen av Afghanistan. immar. Den tidsgränsen har vi passe-

sager Hjukström.

Nationell insamling

ska startas

Svenska Afghanistankommittén är den enda hjalporganisation som stännist
All personal har klarat sig oskadd och kommittén pá hemmaplan kom mer att dra igăng en nationell insam. lingskampanj för att Sverige ska kun na bidra med mat, mediciner, tält och överlevande i katastrofom-

Senast i februari månad omkom öve 5000 människor vid ett jordskalv amma område.

De här människorna har drabbats oerhört hărt. Tvả kraftiga jordskalv $p$ nägra fa manader. Det ska egentligen vara statistiskt omojligt. Det bruka vara 50-100 ár mellan tvà jordbavning arna av den här kalibern, säger Pete Hjukström.

Bergen havererar

I Jordskreden

Landskapet i nordöstra Afghanistan är kuperat.

Den odlingsbara marken ligge längst ner $\mathrm{i}$ dalgàngarna och människorna bygger sina bostäder läng bergskanterna.

- Jordskred făr bergen att haverera. Hela byar áker ner i dalgångar när bergssidor rämnar, berättar Peter Hjukström.

\section{0 dödsoffer vid jorddbärning}

FAISABAD. Flygplan lastade med fornödenheter flög pá måndagen frán Pakistan till det isolerade norra Afghanistan där soldater satt $i$ gång sökandet efter överlevande 'från den svåra jordbävningen. Uppemot 5000 människor befaras ha omkom mit i lördagens skalv.

Livsmedel, filtar, tall och presenningar skulle ăven sän das med helikopter frán den pakistanska huvudstaden Islamabad till staden. Faisabad det drabbade omrádet.

Frankrike planerar att săn da .35 ton humanitärt bistánd till Tadzjikistan, varifrán det dater redan har hittat 1650 döska transporteras vidare till da. Alliansen strider mot talikatastrofomrádet. Roda korset fick fram ett re delen av landet. Enligt talessöndags och hâller pả att inrät- plánats.

ta en klinik i omradet. $\quad$ Enligt Röda korset kan 5000 Skalvet odelade hela byar, människor ha omkommit. Siffrev sönder berg utlöste jord. rorna är emellertid mycket skred och har lämnat mảnga osäkra.

tusen hemlossa.
FN:s humanitära hjälpcen Bland de döda fanns 140 tral i Pakistan uppskattade att Bland de döda fanns 140 tral i Pakistan uppskattade at skolbarn i Rostaq, en ort som totalt 60000 människor drab

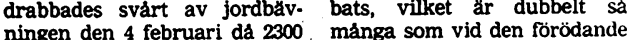
ningen den 4 februari dâ 2300 . mânga som vid den forödand

människor dodades och 8000 jordbänningen i februari. drabbade i lördagens skalv minärt 6,9 pá Richterskalan. bodde ännu i tălt efter det förra Dess epicentrum lág vid grän bodde ännu i tălt efter det förra Dess epicentrum lâg vid gran
skalvet. $\begin{array}{ll}\text { skalvet. } & \text { sen mot Tadzjikistan, sju mil } \\ \text { En talesman for den opposi- väster om Faisabad, som är }\end{array}$

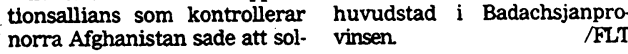
flygplan till Faisabad redan i mannen har átta byar helt utlämnade $\mathrm{i}$ gàr via satellitte

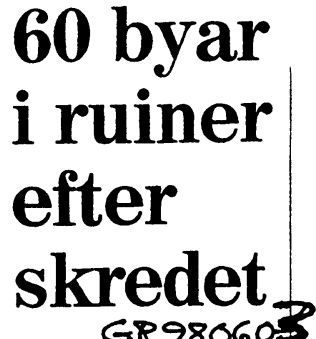

Hjälparbetare sade

$i$ går till nyhets-

byrån Reuters att

lördagens jordbäv-

ning i nordöstra

Afghanistan kan ha drabbat ett betydligt större område än man först trodde.

T-AFP

Svenska Afghanistankommitténs Sidney Pettersson lefon en direktrapport frản det drabbade omrádet till huvudkontoret i Stockholm - I distriktet Rustaq är sex byar utplănade till hundra procent och hittills har 1735 dödsoffer räknats ihop. Shar-i-Buzurgdistriktet har 45 byar förstörts till mellan 100 och 60 procent och mins 2340 dödsoffer krävts.
Det talas om

4000 döda

Internationella rödakorsommitten vill fortfarande inte ens försöka gissa hur mànga som omkom. Inalles bodde cirka 60000 människor i skalvomrádet.

De lokala myndigheterna talar nu om 4000 döda, men ICRC sager att man helt enkelt inte vet. Uppskattningsvis 60 byar lades i ruiner av skalvet som uppmättes till 7,1 pá Richterskalan. För dem som överlevde de senaste skalvet, bland dem nágot tusental skadade, brådskar det nu att fă fram hjälp.

Viktigt att snabbt ordna tak over huvudet

EU utlovade $i$ gàr hjälpsändningar värda närmare 13 miljoner kronor. Många andra löften om hjälp har
ocksa kommit, men den măste framför allt snabbt nå de nödställda.

FN, Röda korset, Läkare utan gränser med flera understryker att folk snabbt măste få tak över huvudet. Pả lite sikt tillkommer risk för malaria, kolera och dysenteri, om inte mat och rent vatten kan föras fram i tid.

Den nya jordbävningskatastrofen får inte vapnen att tystna. Talibanerna som behärskar cirka 80 procent av landet vägrar blissa eldupphör $\mathrm{i}$ inbördeskriget för att hjälpa de nödställda. 
$5 \vee 0 \quad 25 / 4-.98$

Nödhjälp via åsna till afghaner

Islamabad: I mer än ett halvår har det centrala höglandet A. fghanistan varit avskuret från omvärlden av militära skäl. Wu svälter hundratusentals människor, men det enda FN kan göra är att försöka föra in mat med häst- och åsnekaravaner.

Två representanter för FN:s livsmedelsorganisation WFP tar sig just nu med häst genom Hazarajat-regionen för att utreda hur stort akut hjälpbehov som råder. Delegaterna väntas inte tillbaka på ännu en vecka, men WFP har redan tydliga tecken på en omfattande katastrof. TT-REUTERS

Svenska Afghanistankommittén beslutade på măndagen att starta en nationell insamling till stöd för offren i helgen jordbävning i nordöstra Afghanistan. Kommittén har redan folk i området men vad som saknas är pengar. TT SVD

$$
\text { iो }-93
$$

\section{Svår jordbävning i norra Afghanistan}

Moskrva: Tusentals människor befaras ha omkommit i en kraftig jordbävning i norra Afghanistan på lördagen. Hela byar är begravna men det är mycket svårt att fă kontakt med det drabbade bergsområdet och afghanska myndigheter har inte kunnat ange antalet döda. Hjälparbetare uppgav för nyhetsbyrån Reuters att 36 byar totalförstördes i distrikten Rostak och Chah Ab.

Jordbävningen mätte 6,9 på Richterskalan, enligt preliminära mätningar. Dess epicenter låg på gränsen mot Tadzjikistan, sju mil väster om Badachsjanprovinsens huvudstad Faisabad. Den anti-talibanska allians som kontrollerar regionen uppger att det värst drabbade området är kring staden Shari Basurch.

- Vi tror att kanske 3000 människor har dödats i Shari Basurch, sade alliansens talesman Abdullah. AP

sing $31, y-98$

\section{Offren får hjälp för sent}

AFGHANISTAN. Den avsatte presidenten Burhanuddin Rabbani anser att den internationella hjälpinsatsen till jordbävningsoffren drar ut för mycket på tiden. Mångadrabbade väntar fortfarande pá hjälp.

Rabbani kom pả onsdagen med helikopter till Shari Basurkh, ett av de värst drabbade områdena, för att medla i en konflikt mellan rivaliserande befälhavare i de styrkor som bekämpar talibanregimen. Styrkorna, som är baserade i delvis samma del av landet som jordbävningen drabbat, har länge plågats av interna fejder.

FN och Röda korset har samordnat sina insatser för att kunna hjälpa de avlägsna byar som ännu inte nåtts av hjälp. Nu gäller kampen framför allt mat och vatten, i flera byar har invânarna inte ätit på fem dagar.

FN har vädjat om hjälp frản världens länder med fler helikoptrar och bränsle. Sedan dess har en del bränsle anlänt till Tadzjikistan, men verkar ha fastnat där.

I Shari Basurkh dödades främst gamla, kvinnor och barn. eftersom skalven kom pá morgonen, då männen är ute och arbetar pà fälten. Många människor är i chock och flera sover utomhus i rädsla för efterskalv. DN $416-98$

\section{$S \cup \cdot D \cdot 5 / 6=-98$ Fyra byar förstörda i efterskalv}

Faizabad: Ett kraftigt efterskalv anställde natten till torsdagen förödelse i ytterligare fyra afghanska byar, meddelar FN. Samtidigt rapporterar Svenska Afghanistankommittén om stora jordskred i katastrofomrảdet.

Tre rörliga vårdteam från Afghanistankommittén var pả torsdagen pả väg till fots eller med hästar och åsnor genom väglösa trakter till tre byar norr, öster och nordöst om Rustaq. De rapporterar om översvämningar och stora jordskred. Ett 6o-tal läkare, sjuksköterskor och annan personal från sjukhus och vảrdcentraler som kommittén driver på andra platser har skickats in i katastrofområdet.

Nattens efterskalv var kännbara framför allt i Shar-i-Buzurg-området, som anses vara värst drabbat i den region pá I 750 kvadratkilometer som berördes av den stora jordbävningen i lördags. Här levde tidigare cirka 70000 människor. Fortfarande är det oklart hur många som omkom - uppgifterna pendlar mellan 3000 och 5000 .

Hjälpinsatserna underlättas nu något sedan USA meddelat att man kan skaffa fram två stora helikoptrar till på lördag. TT-REUTERS

\section{Väder stoppar matbombning}

AFGHANISTAN. Uselt väder stoppade på fredagen matleveranser till nödlidande i norra Afghanistan.

Matpaket skulle ha släppts ned från helikoptrar, men vädret var sả dåligt att flygningarna inte kunde genomföras.

- I går hade vi helikoptrar men inget bränsle. Idag har vi bränsle men inga helikoptrar, suckade FN-talesmannen Rupert Colville sedan tre helikoptrar blivit kvar i grannlandet Tadzjikistan varifrån en stor del av nödhjälpen forslas in

I torsdags lyckades man matbomba 12 av 28 helt raserade byar med vete och olja. De 16 ảterstảende byarna i sämst skick hade man hoppats ná under fredagen. Ett tiotal byar som troddes vara i utsatt läge hade ännu inte nảtts av nảgra katastrofinsatser alls

Antalet döda är fortfarande oklart. E/6-98T-AFP

\section{"FN får inte fram hjälpen till drabbade afghanska byar"}

Trots att det finnshelikoptrar når mathjälpen inte fram till delar av de jordbävningsdrabbade områdena i Afghanistan: Det hävdar Per Hoimfelt, förbundssekreterare för den norska Afghanistankommittén. Deras koordinator i Shahr-e-Bozurg berättar att det kommit flera helikoptrar, men utan mat. Istället har bybor erbjudits att sända med chockade barn till sjukhus. För de flesta afghaner är det otänkbart att lämna sina barn ifrån sig.

Per Hornfelt kommer att vända sig till FN och Röda korset, via norska UD, för att få svar på varför hjälpen inte fungerar. De närmaste dagarna är avgörande för om svält ska drabba de omkring 16000 hemlösa i området. Afghanistankommittén och organisationer som de samarbetar med har ordnat en konvoj från Faizabad som är framme om tidigast tre dagar. Kanske hinner den före eventuell helikopterhjälp. उUD $8 / 6-98$

HASSE BOSTRÖM

\section{Jordbävningsoffer utan mat}

Malmø: Det är svårt att få fram mat till de omkring 200000 jordbävningsdrabbade människornai nordöstra Afghanistan. Barn dör i svält i väntan på att de fåtaliga helikoptrarna med mat ska hitta fram. Det berättar Sidney Petersson, Svenska Afghanistankommitténs regionchef på platsen, som ledde den stora räddningsinsatsen efter den senaste jordbävningen den 30 maj. Han har just anlänt till Sverige.

- Tyvärr fungerar inte FN:s distribution ordentligt. Det är brist på helikoptrar. Dessutom hittar piloterna ibland inte.

Afghanistankommittén har transporterat långt större mängder mat och läkarlag med bil och vidare med åsnor. Kommittén arbetar tillsammans med lokalbefolkningen och har lättare för att komma fram. FN-systemet är tungarbetat, menar Petersson. TT SU'D 13/6-98 


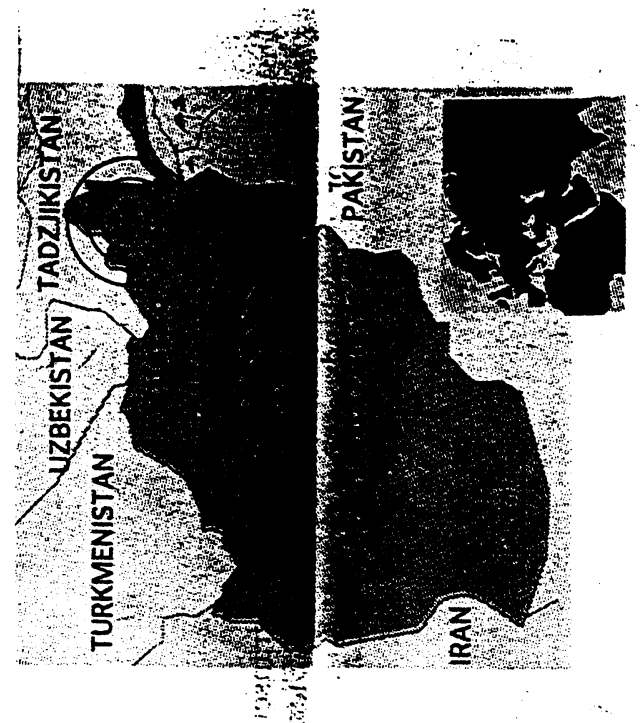

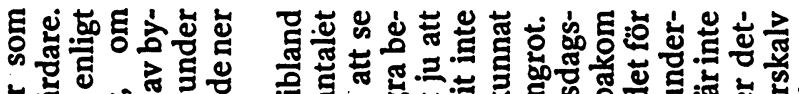

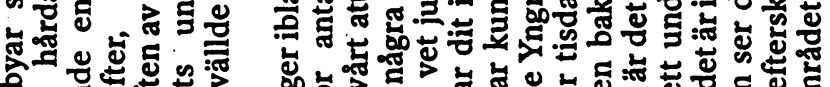

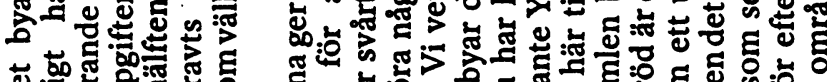

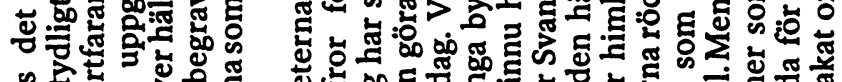

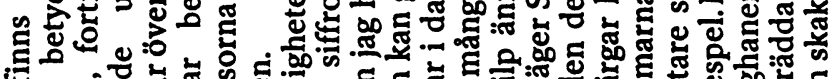

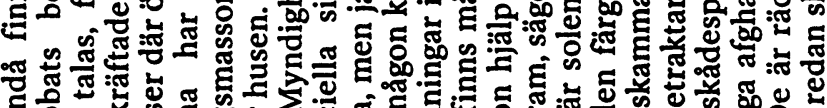

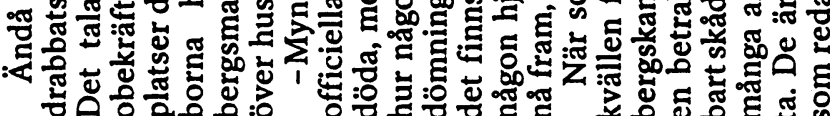

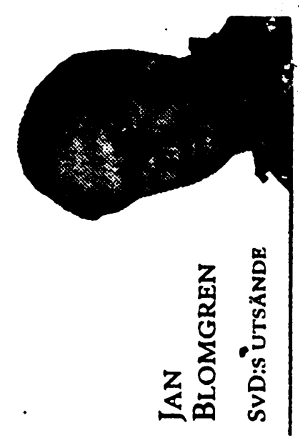

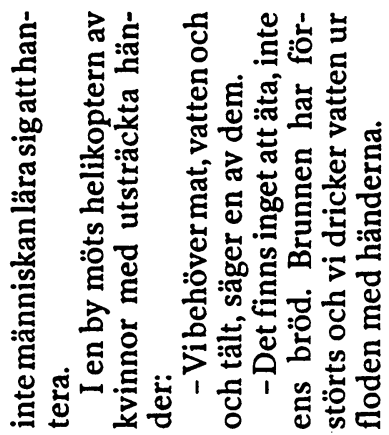
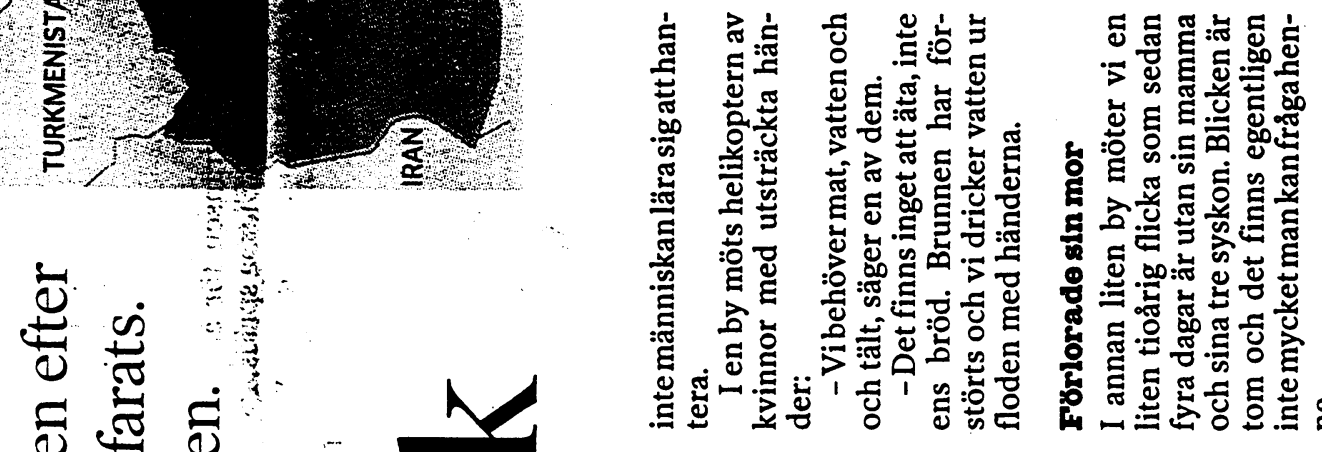

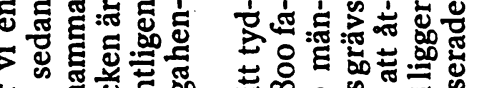

过芯引

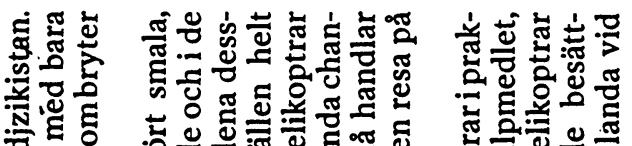
침 :

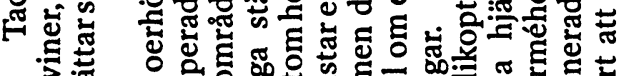

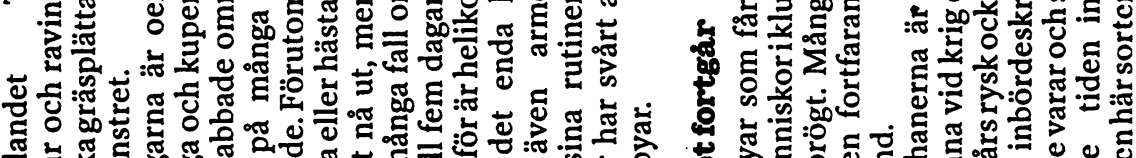

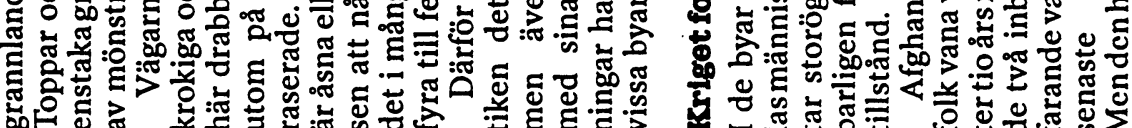

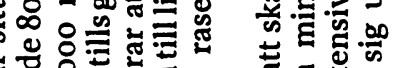

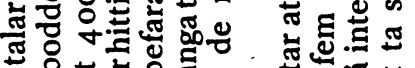

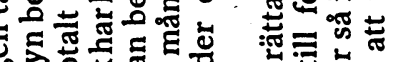

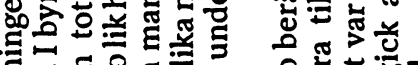

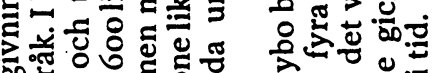

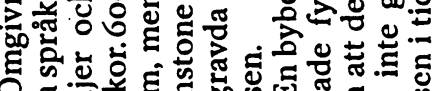

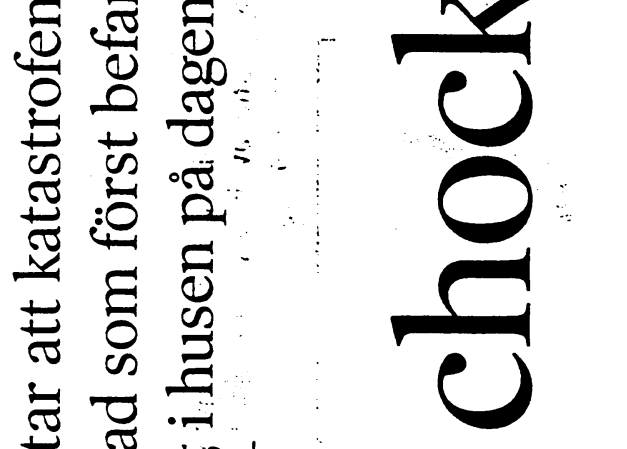

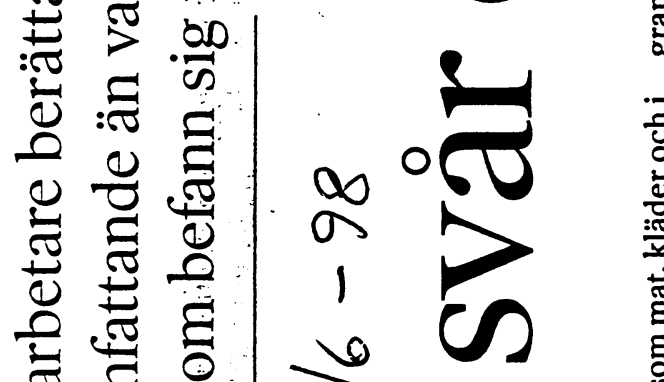

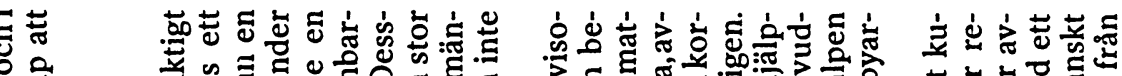

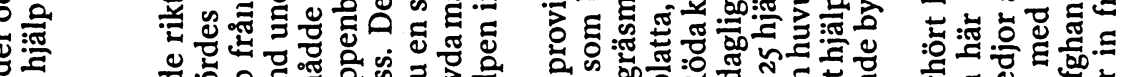

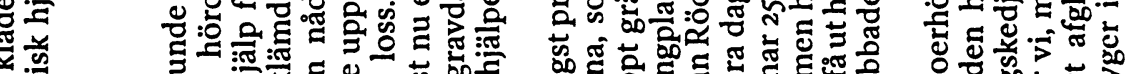
量

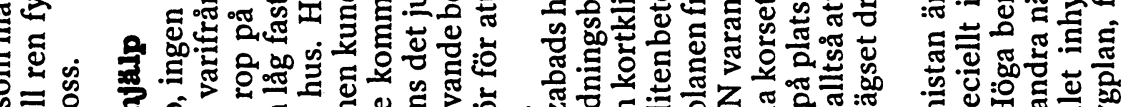

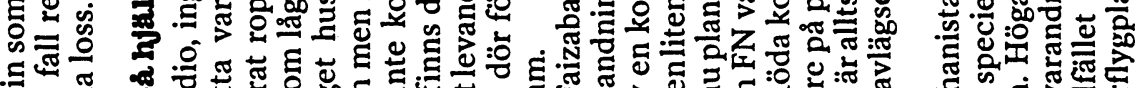

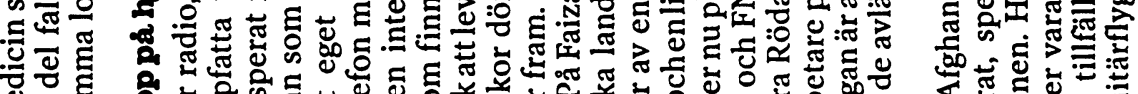
绕

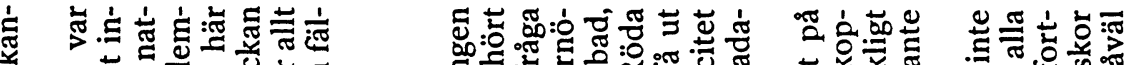

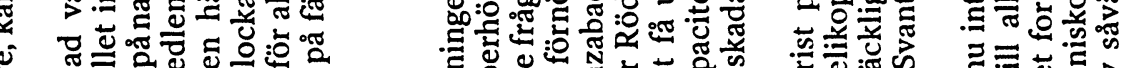

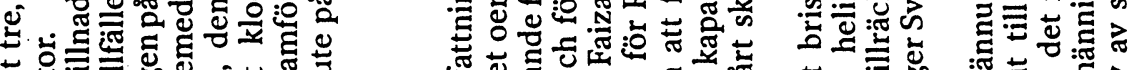

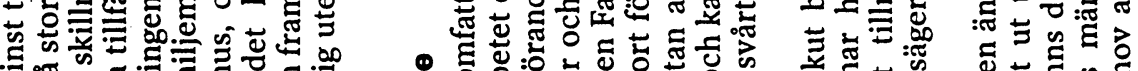

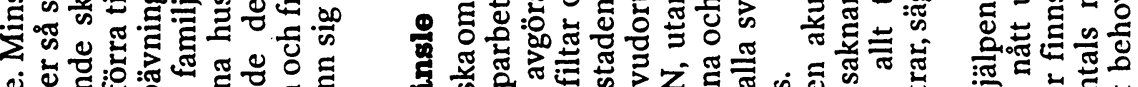

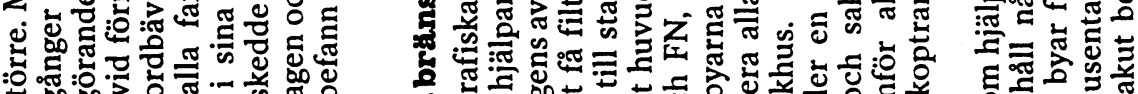
읍

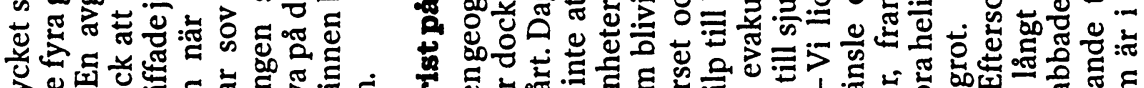

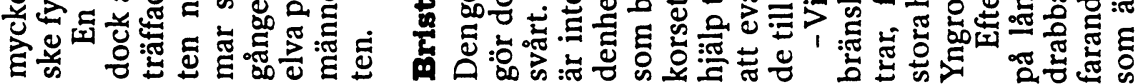

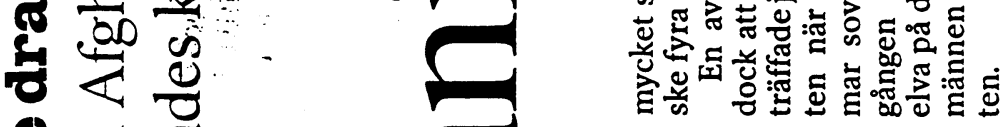

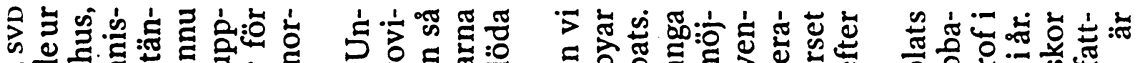

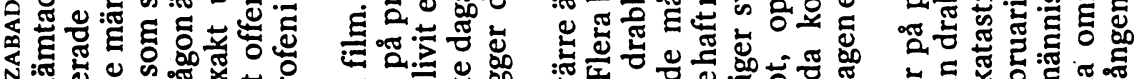

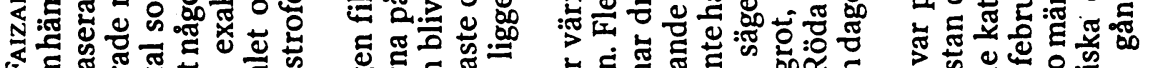

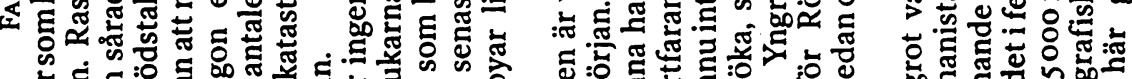

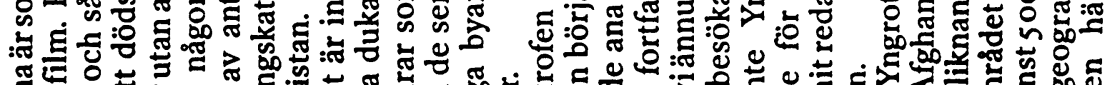

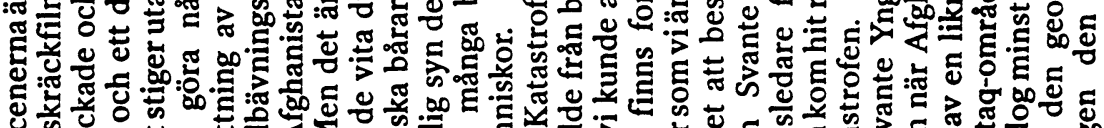

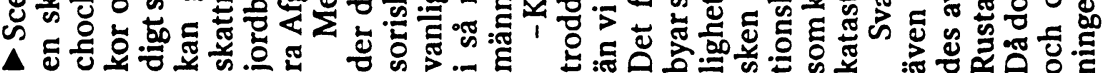




\section{Svåra skalv under 90-talet}

Den senaste jordbävningen i Afghanistan är en av de värsta under 1990-talet.

Iran 1997: Östra Iran drabbades av en jordbävning. 7,I på Richterskalan. 1560 dödades och II byar ödelades.

Ryssland 1995: Den värsta jordbävningen i Ryssland drabbade ön Sachalin. Skalvet hade en styrka på 7,5.

Japan 1996: Tre veckor efter skalvet på Sachalin, drabbades den japanska storstaden Kobe. 6340 dödades och skadorna blev mycket omfattande. Skalvets styrka låg på 7,2.

Colombia 1994: Ett jordskalv kombinerat med jordskred orsakade en tragedi i dalen vid floden Paez, i sydvästra Colombia. Omkring 1000 dödades.

Indien 1993: Över 20000 dödades och 36 samhällen förstördes i östra och södra Indien efter en rad skalv av vilket det första hade styrkan 6,4 .

Indonesien 1992: Flera öar i provinsen Östra Nusa Tenngara drabbades av skalv med styrkan 6,4. Minst 2200 dödas. Fulippinerna 1990: Ett skalv med styrkan 7,7 krävde,2000 dödsoffer. 150000 blir hemlösa.

Iran 1990: Landets värsta naturkatastrof med 50000 döda, 100000 skadade och en halv miljon hus raserade i regionen Gilan och Zanjan vid Kaspiska havet. Skalvet hade styrkan 7,7 på Richterskalan. REUTERS $5 \cup D 3 / 6-98$

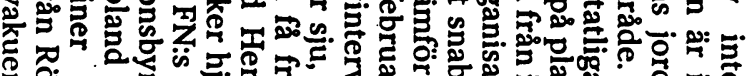

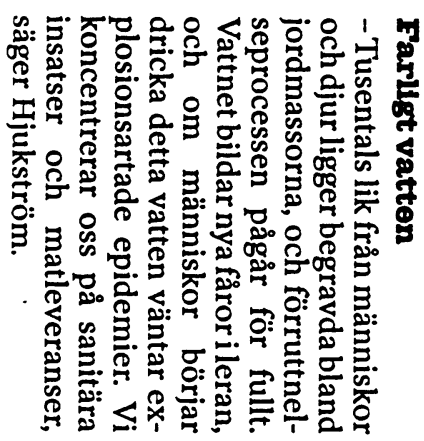

\section{Afghanistan drabbat}

\section{Minst 5000 döda i jordskalvet}

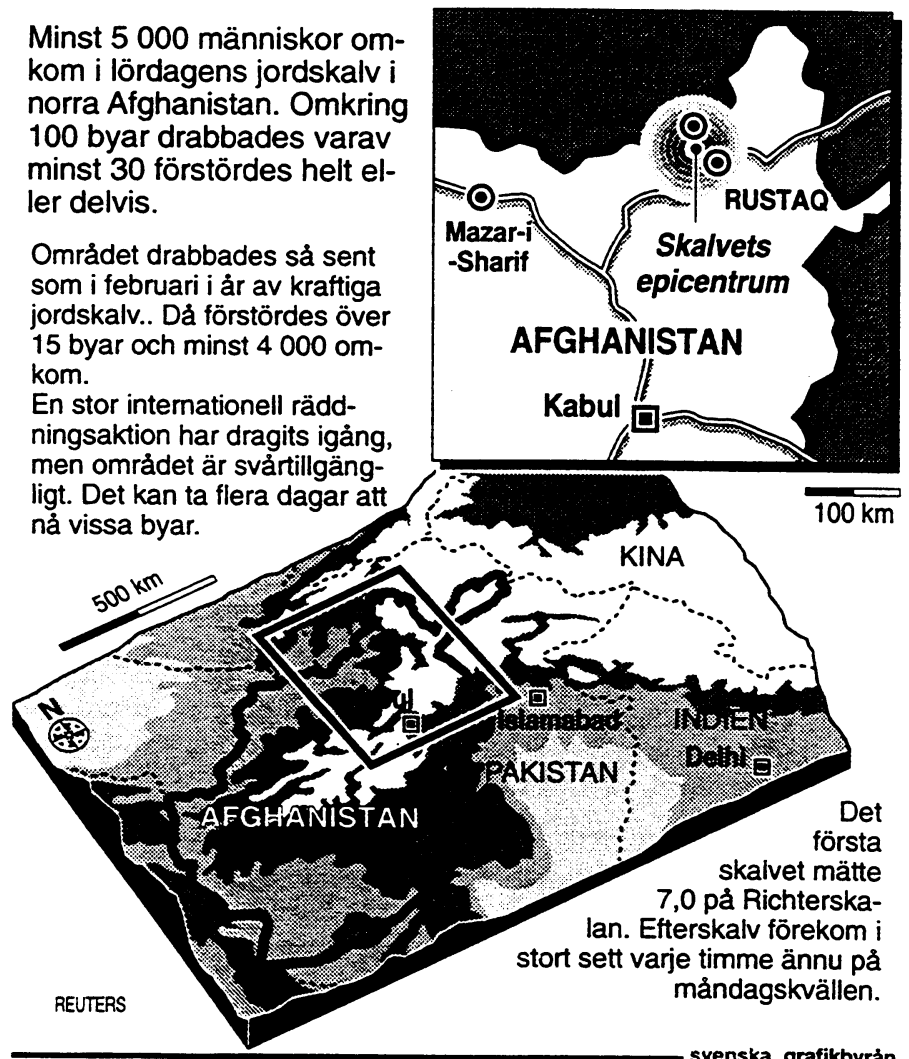

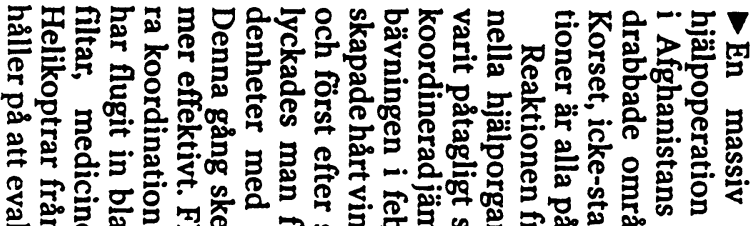

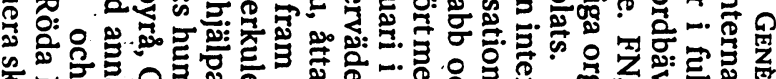

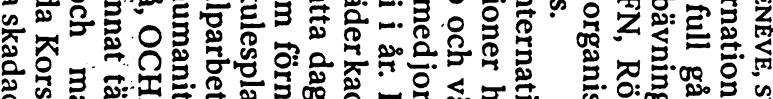

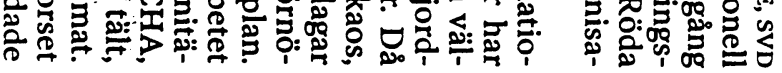
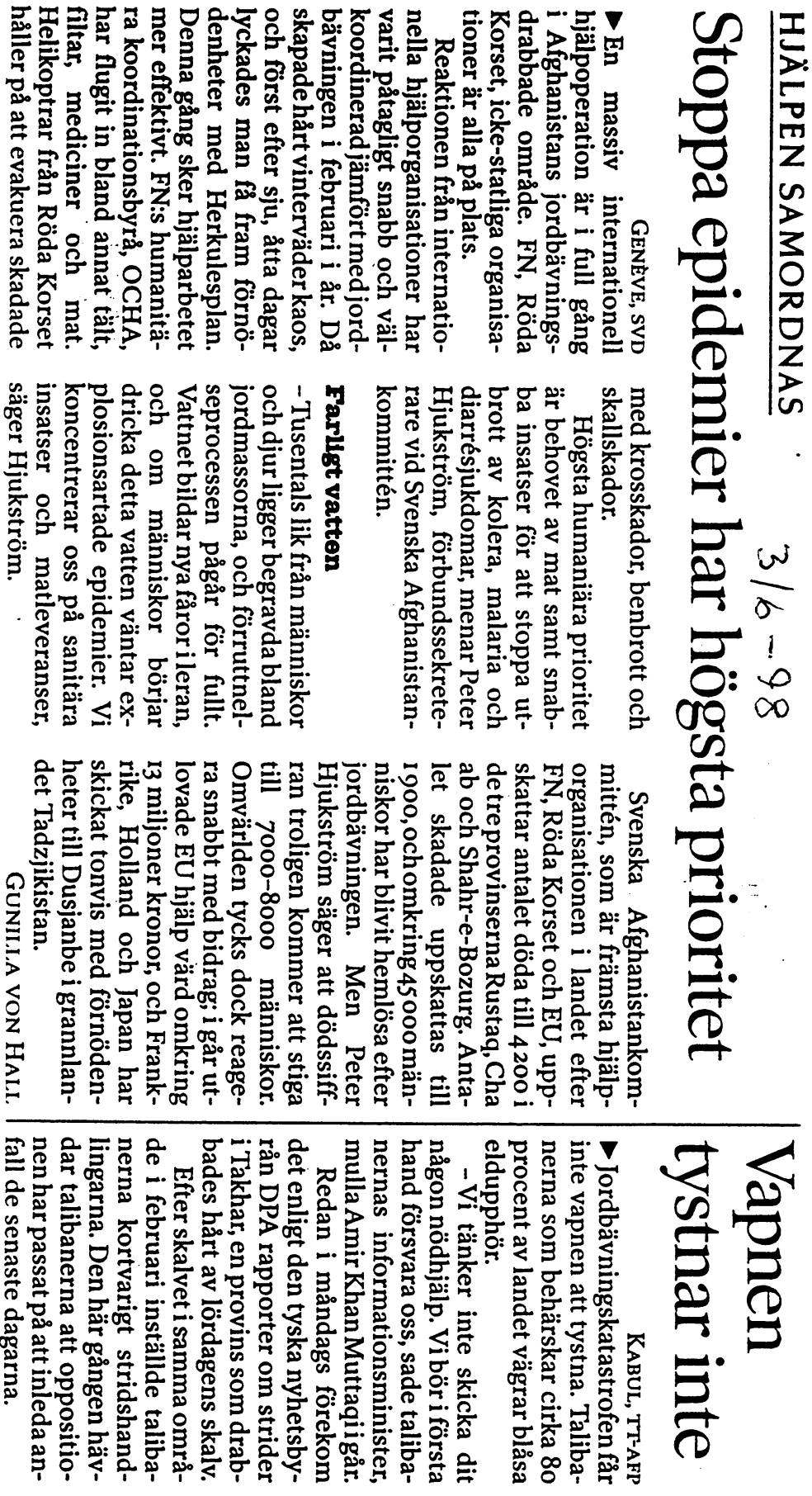

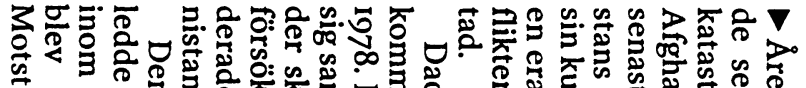
量 3 के

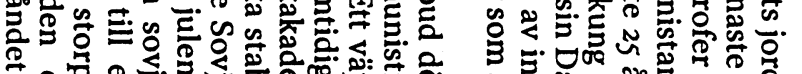

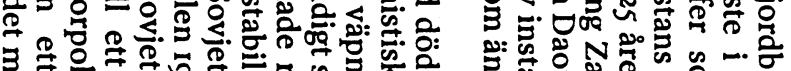

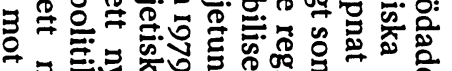

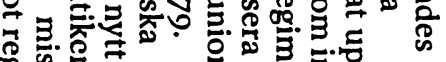

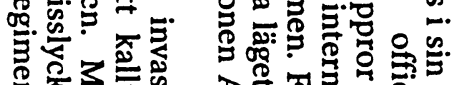

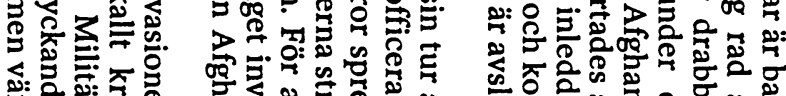

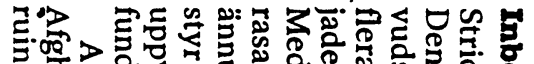

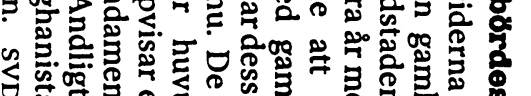

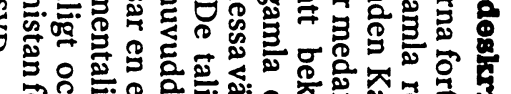

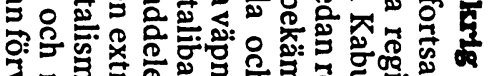

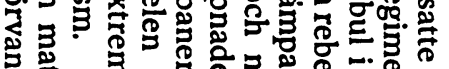

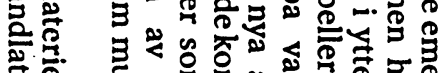

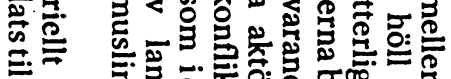

言焉

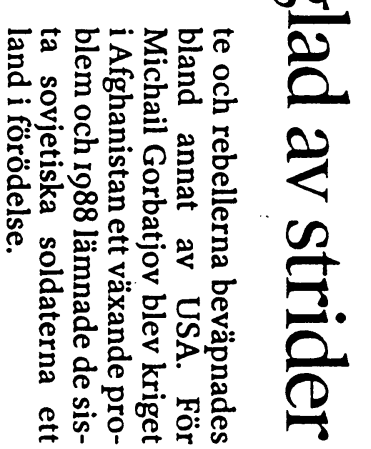

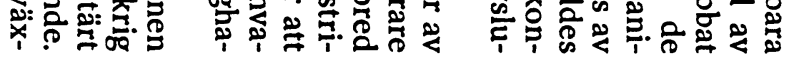




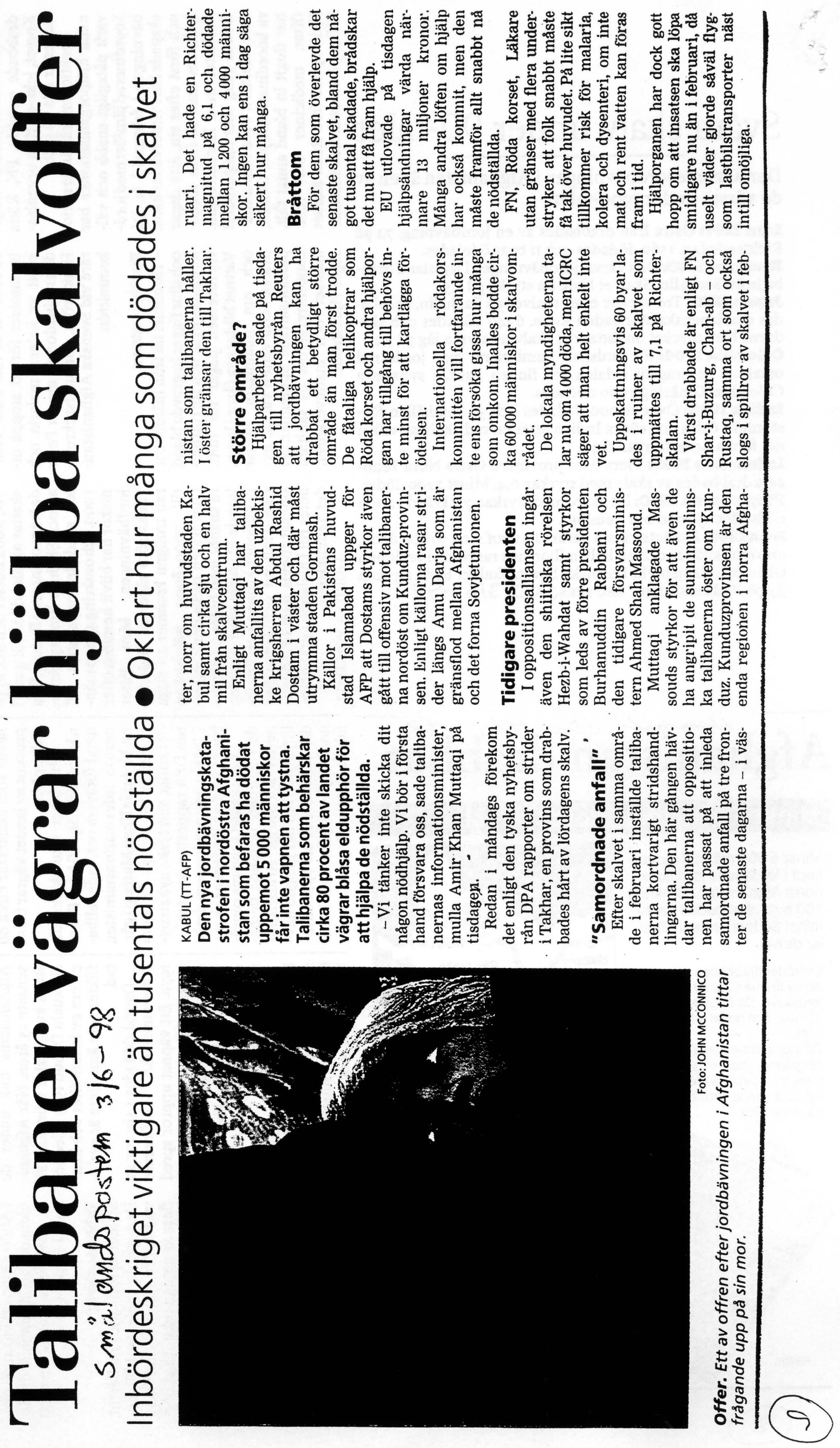



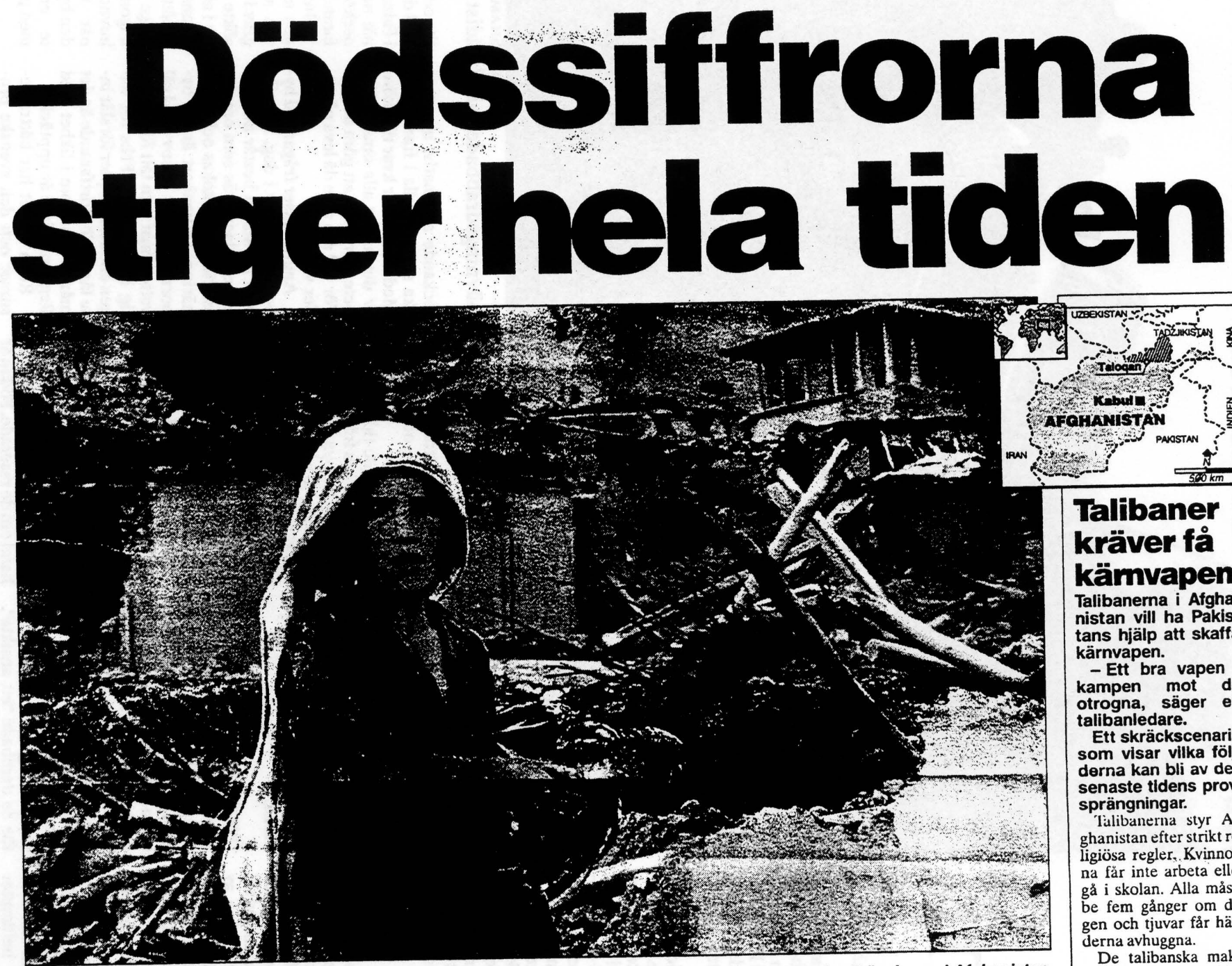
BARNEN HAR DET SVARAST Det är främst kvinnor och
Uppskattningsvis har minst 5000 männlskor dött I katastrofen.

Svenske Sidney Petersson räddar liv i Afghanistan

Barn och kvinnor dör runtom svensken Sidney Petersson.

Han spelar en central roll I räddningsarbetet I det jordbävningsdrabbade Afghanistan.

- Förstörelsen är bedövande, berättar han frản katastrofområdet.

Dödssiffran stiger hela tiden. Minst 5000 har omkommit.

Sidncy Petersson från Malmö var en av de första hjälparbetarna som nảdde det otillgängliga jordbäyningerabe ningsdrabbade om

Synen som mötte honom var ohygglig.
- Vissa byar är helt raserade, berättar han på en knastrig telefonlinje. Vartenda hus är förvandlat til smågrus. Många av dödsoffren kvävdes $i$ jordskred som begravde husen.

De flesta offren är kvinnor och barn. Männen jobbade på fälten.

Drabbas hairt

ännu en gång

Dut är andra gången $p a$ mindre àn ett halvår som denna bergiga del av Afghanistan drabbas av en svår dades nunt 4000 människor. Nu är ratastrofområdet nästan dubbelt så stort.

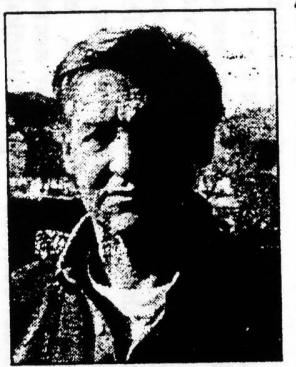

Svensken Sidney Peterson berättar om den hår drabbade befolkningen.

Vissa av de som drabbades förra gången är pả nyt offer för naturkrafterna.

- I dag besökte jag en by där vi precis börjat återuppbyggnadsarbetet efter den förra katastrofen, berättar Petterson. Nu är allt raserat igen. Ett svårt slag för de som drabbats ännu en gång. Många av dem har tappa modet fullständigt.

Sidney Peterson bor nu Afton bl arlet $3 / 6-9)$

Afghanistan. If ton blarde $3 / 6-93$ Folo: REUTES en lerhydda i Taloqan med riskfaktor. Inbördeskriget. en satellittelefon som enda Talibanerna, som kontrolkontakt med yttervärlden. lerar större delen av landet El till telefonen får han via men inte de norra delarna, ett bilbatteri.

Hemma i Malmö sitter hustrun Marianne och dot- lätta hjälpsändningar til tern Sarah och följer oroligt jordbävningsområdet.

TV-bilderna från katastro- - Jag ärmer orolig närjag rör mig i områden där det Sidneys jobb är att skaffa förekommer striderän mitt i

fram mat, mediciner och lä- jordbävningszonen, säger kare till de lidande.

\section{Talibanerna ä}

\section{ett stort hot}

Sverige spelar en central roll i hjälparbetet tack vare Svenska Afghanistan-kommittén som finns på plats ute på landsbygden sedan yssama invaderade Afghanistan 1979.

- Vi har tre små sjukhus ch en vårdcentral $\mathrm{i}$ katafområdet, berättar Peter Hjukström, förbundssekre(erare. De har direkt kunnat ta hand om skadade.

Förutom kraftiga efterskalv finns ytterligare en inte långt bort men bergen attackera med bombplan.

Hittills har 4200 döda hit-

tats. Men nảgra av de värst drabbade byarna ligger sà isolerat att man inte kunna nå dem ännu.

-Döds-
siffran
kommer
att stiga
till över
5000 , sä-
ger Peter
Hjuk-
ström.
gör att talibanerna bara kan

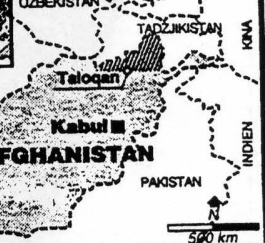

Talibaner kräver få kämvapen Talibanerna i Afghanistan vill ha Pakistans hiälp att skaffa kärnvapen.

- Ett bra vapen i kampen mot de otrogna, säger

talibanledare.

Ett skräckscenario som visar vilka föl]derna kan bli av den senaste tidens provsprängningar. ghanistan efter strikt religiösa regler. Kvinnorna făr inte arbeta eller gå i skolan. Alla måste be fem gånger om dagen och tjuvar får händerna avhuggna.

De talibanska makthavarna är tillräcklig fanatiska för att använda kärnvapen om de fár chansen.

\section{"Normalt att} piska kvinnor" För några månader sedan träffade jag viceministern som nu uttalar önskan att skaffa kärnvapen. Då försökte han övertyga mig om det normala i att piska kvinnor som rör sig utde slöja. Qalamuddin sevärt större än titeln viceminister för departeceminister for "förhindra synd och främja renlevnad" kan få en att tro tillhör de mest hårdföra talibanerna.

När han säger att talibanerna vill utveckla kärnvapen "om vi kan" är hotet värt att ta pă allvar. Talibanerna har mycket bra relationer Pakistan.

Wolfgang Hansson 


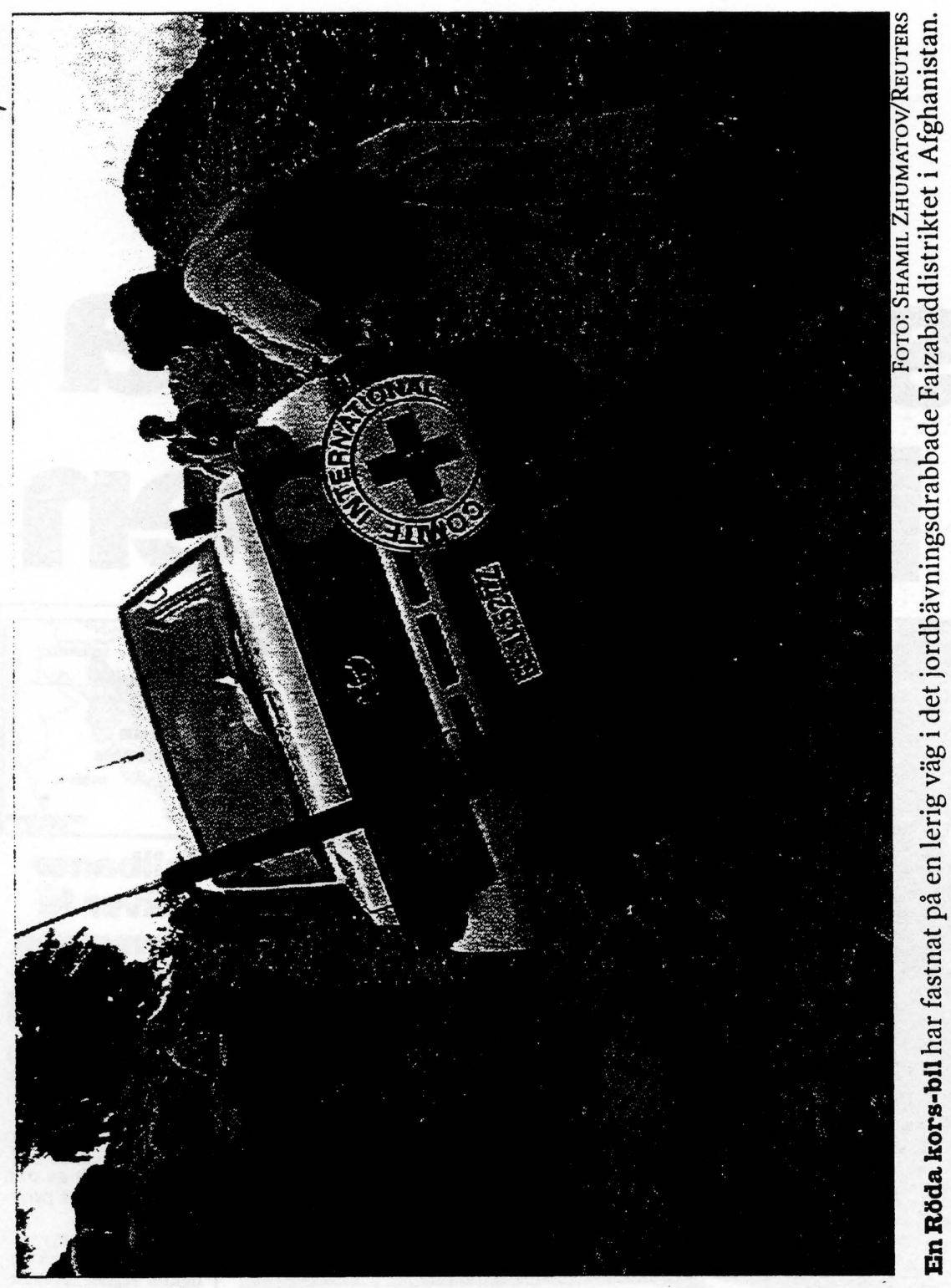

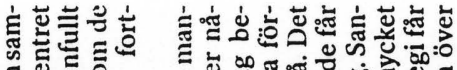

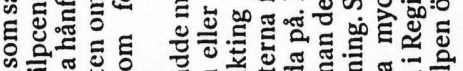

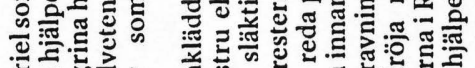

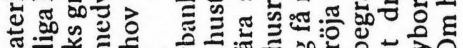

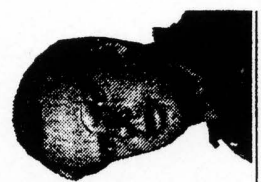

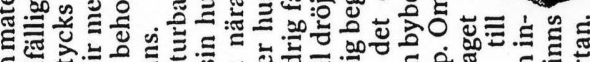

可

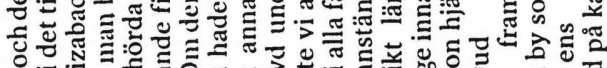

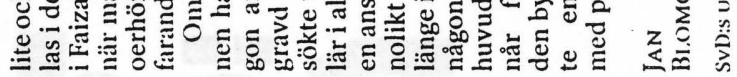

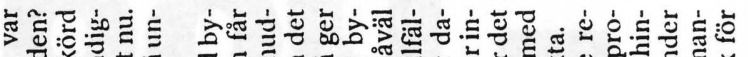

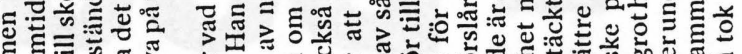

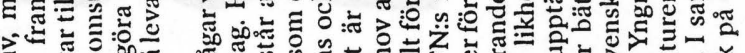

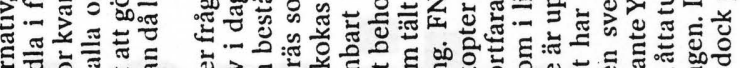

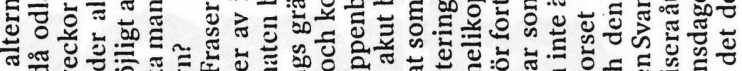

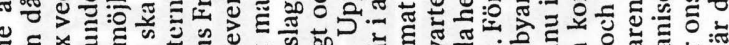

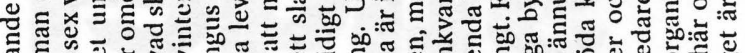

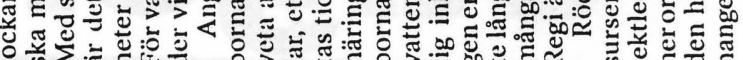

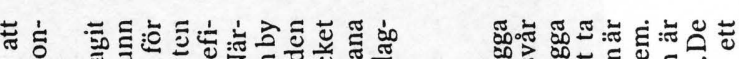

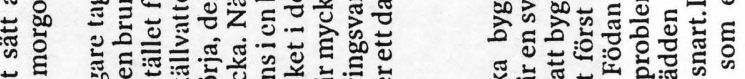

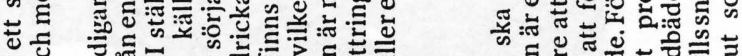

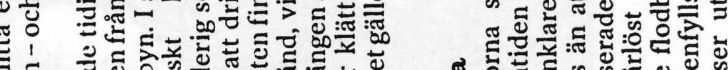

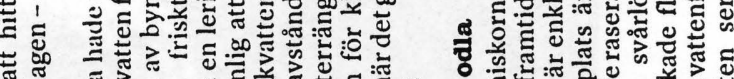

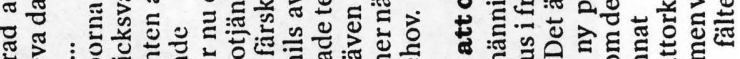
吅

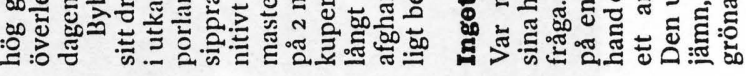

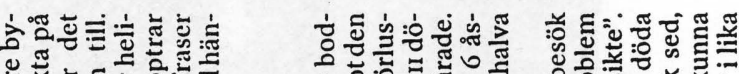

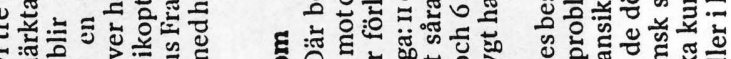
5.

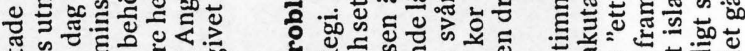

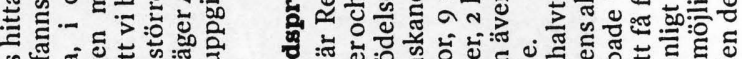
焉.

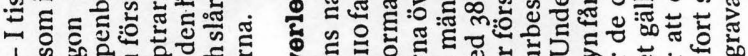

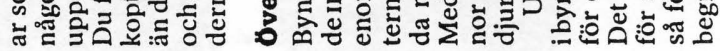

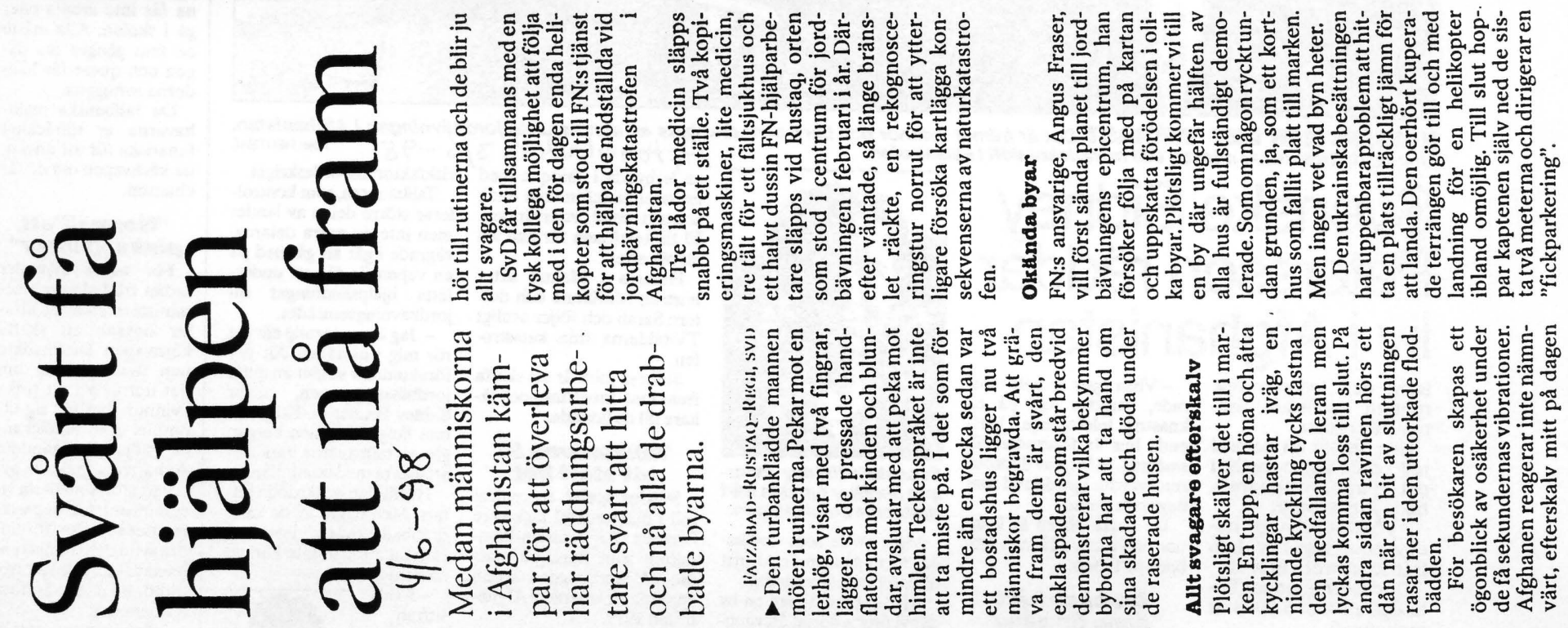




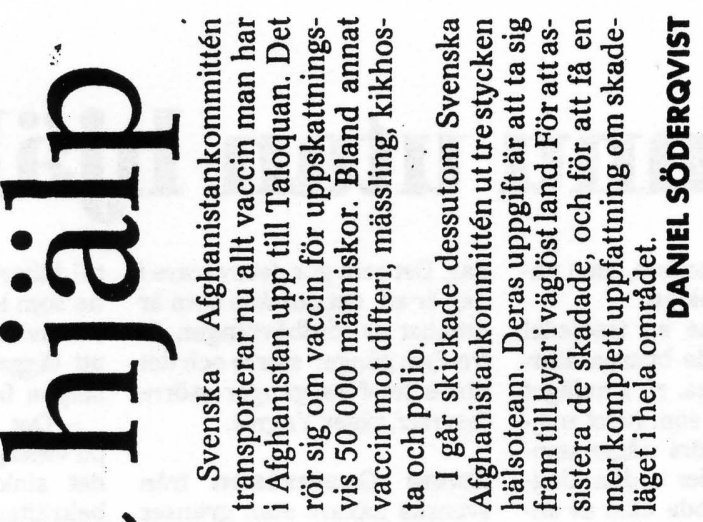

ฮ)

ᄃ

:

$\frac{0}{0}$

$\stackrel{5}{ \pm}$

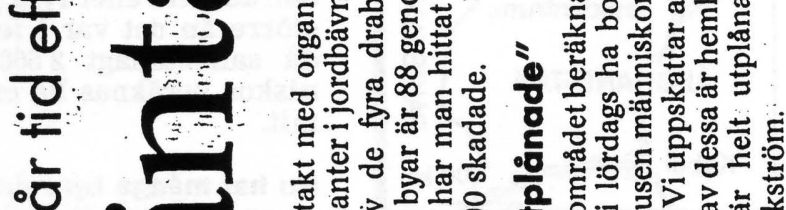

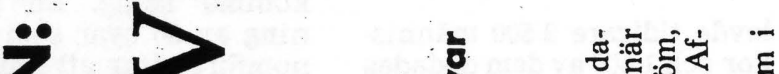

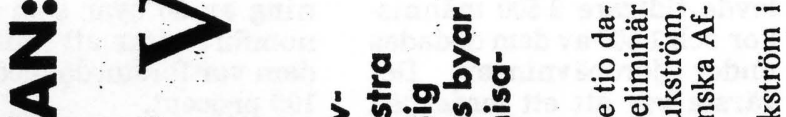

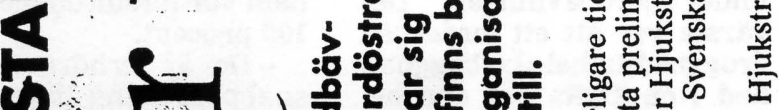

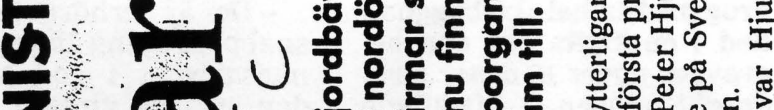

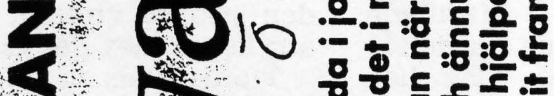

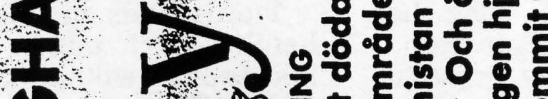

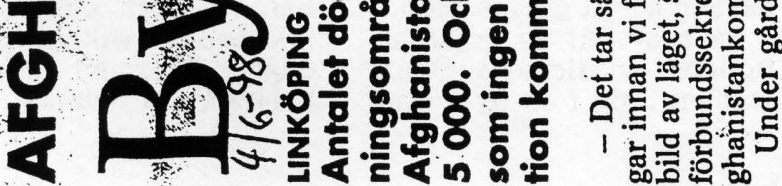

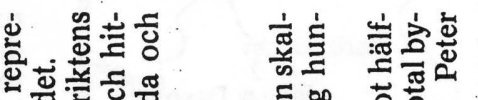

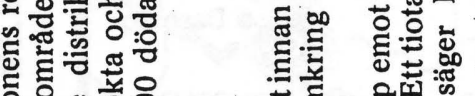

施

苍棺

t)

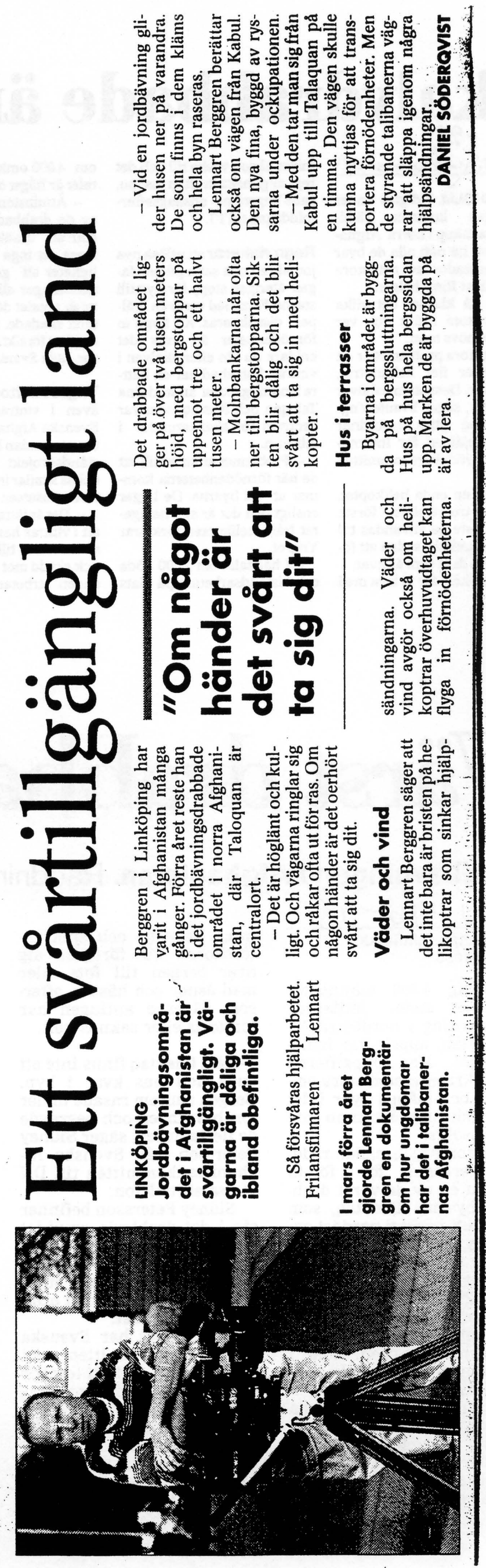

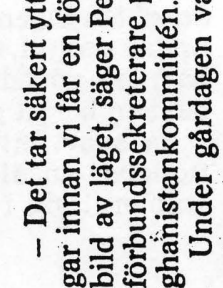

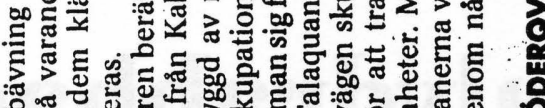

음

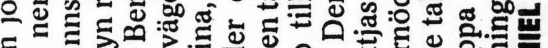

옹

政

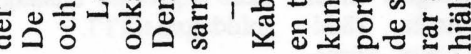

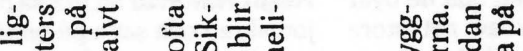

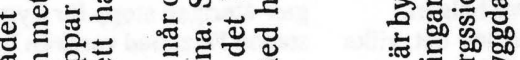

है

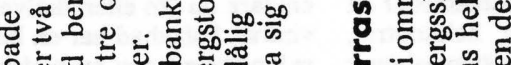

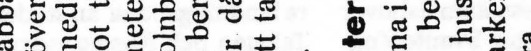

ธ。

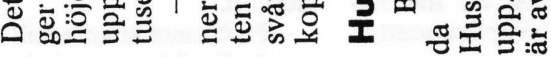

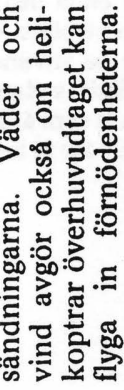

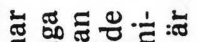

क्ष

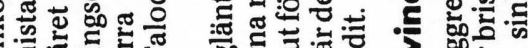

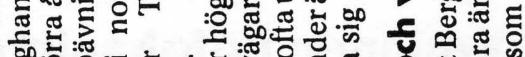

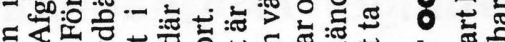

㟧-

$>\quad \sigma$

=

ह $>$ >

.

\section{을}

동ㄷㅇ

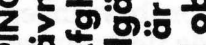

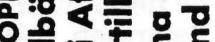

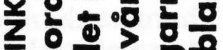

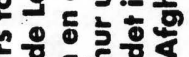

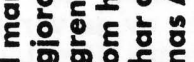




\section{Skalvdrabbade ännu utan hjälp \\ $46-98$}

Fran $\pi S y d$ su 2mskan

STOCKHOLM. Tidigast under torsdagen kommer räddningsmanskap i norra Afghanistan att ha nått alla de byar som raserades av det stora jordskalvet förra helgen.

Först då klamar det vilka insatser som krävs och var dessa behövs mest.

- Det stora problemet är att vi behöver fler helikoptrar, och större. Dessutom behöver vi bränsle, säger Svante Yng rot som pá plats samordnar katastrofhjälpen för Internationella rödakorskommittén (ICRC).

FN har en enda helikopter ICRC har tre på plats. I första hand måste de användas till att få ut skadade, sedan att föra mat till dem som är kvar

- Efterskalv får vi leva med minst någon vecka till och det regnar ganska kraftigt just nu sade Yngrot på onsdagseftermiddagen till TT.

Regn riskerar att utlösa nya jordskred och satte på onsdagen áterigen stopp för flyg till staden Faizabad varifrån hjälpen distribueras. Att flyga in förnödenheter är trots det enklare nu än efter skalven vintras: Faizabad har en bättre landningsbana än städerna Taloqan och Rustaq, som var centrum för skalvområdet i februari.

- Problemet är att se till att de här förnödenheterna kommer ut till byarna. De ligger ensligt och det är svårnavigerat frản helikopter, förklarar Yngrot.

FN har talat om 2500 döda och biståndsarbetare på plats om 4000 omkomna, men antalet är högst oklart.

- Átminstone en tredjedel av de drabbade byarna återstår att besöka, så i nuläget finns det inga som helst möjligheter att göra några uppskattningar eller bedömningar av antalet döda eller av antalet skadade. Jag skulle vara mycket försiktig med alla siffror, sade SvanteYngrot.

Yngrot deltog i hjälparbetet även i vintras, liksom bl a Svenska Afghanistankommittén som sedan länge driver biståndsprojekt i trakten och också samlar in pengar till katastrofinsatser.

- Det är lättare nu såtillvida att $i$ vintras handlade det också om att se till att människor fick skydd mot kölden. Den fienden arbetar vi inte med $i$ dag. Det som gör det svårare $i$ dag är att det område som är drabbat av jordbävningen är tre-fyra gånger större och det krävs tre-fyra gånger större resurser, säger Yngrot.

Janne Gustavsson från svenska Läkare utan gränser var pả onsdagen på väg mot Afghanistan för att tjänstgöra i katastrofomrádet. Sedan tidigare finns sjuksköterskan Irene Johansson iTalogan.

Nu hoppas ICRC och FN på en leverans av flygbränsle från Dusjanbe i grannlandet Tadzjikistan, men transporter försváras ocksả av det politiska läget. Omrảdet behärskas av olika motståndsgrupper som bekämpar de bokstavstroget muslimska talibanerna. Afghanska Röda halvmånen försöker mobilisera folk till fältarbetet, men talibanerna som kontrollerar lejonparten av Afghanistan är ovilliga att lägga ned vapnen för att släppa fram hjälp.

- Det förekommer strider på vissa platser i omrảdet, och det sinkar räddningsarbetet, bekräftar Svante Yngrot.

Sedan skalvet i februari hade raserade byar inte hunnit byggas upp igen. Fortfarande bodde mảnga i tält, vilket kan ha räddat livet på en del eftersom husen normalt är illa byggda.

Till skillnad frản i februari, då det var väldigt kallt, har merparten av lokalbefolkningen stannat kvar kring sina hem.

- Nu kan de kanske överleva på plats - och skörden ska tas in i juli, så de har inget val, säger SvanteYngrot.

\section{Värst drabbade får hjälp}

\section{Jordbävningen i Afghanistan. Räddningspersonal framme i byn Dashtaq.}

\section{DN $5 / 6-98$}

\section{Av Michael Winiarski}

08-738 1050

Omkring 4000 människor dödades under lördagens jordbävning-i nordöstra Afghanistan, uppskattar hjälparbetare. Men uppgifterna är osäkra eftersom stora områden och många byar i det drabbade området ännu inte har besökts.

På torsdagen nådde räddningspersonal för första gången en av de värst drabbade byarna, Dashtaq, som ligger ett par mil nordöst om Rustaq, som drabbades svårt av den förra jordbävningen $\mathrm{i}$. februari. I Rustaq omkom då över 2000 människor. $\mathrm{Nu}$ har samhället blivit ett slags centrum for den internationella hjälpinsatsen, som i första hand kommer dit med hjälp av helikoptrar.

Därifrån sänder Svenska Afghanistankommittén ut mobila sjukvårdsteam som tar sig ut genom dalgångarna till andra byar med läkemedel och räddningsutrust- ning. Läkarna och sjuksköterskorna får förflytta sig över bergen till fots eller med åsnor och hästar, eftersom vägarna antingen har förstörts eller saknas helt.

- Här i Dashtaq finns inte ett enda helt hus kvar i byn. Bergen runtom rasade under jordbävningen och begravde de flesta husen, säger Sidney Petersson frản Svenska Af ghanistankommittén till DN via satellittelefon.

Sidney Petersson befinner sig $\mathrm{i}$ det drabbade området för att på plats utvärdera hjälpbehovet och fördela de hjälpinsatser som med stora svårigheter fors in i det otillgängliga området.

Sammanlagt har Svenska Afghanistankommittén ett 60-tal läkare, sjuksköterskor och annan vårdpersonal i området. Ännu har varken FN eller Röda korset nått byn. Sydney Peterssons vittnesmả från Dashtaq är skakande.

- Byn är totalförstörd. Här

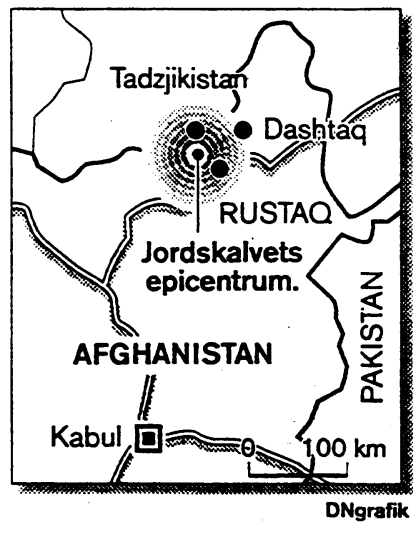

levde tidigare 2500 människor och 1500 av dem dödades under jordbävningen. Det värsta var att ett jordskred drog med en hel skolbyggnad ned i en klyfta och den begravdes under 15 meter jord. Jordbävningen inträffade under skoltid, och alla de 140 barnen dödades. Idag har barnen börjat grävas fram.

Så snart ett av organisationens medicinska team etablerat sig i en by ström. mar människor från omgivningarna dit med sina skadade. Bara under torsdagen tog läkarlaget i Dashtaq hand om 264 patienter, berättar Sydney Petersson.

Enligt Sidney Petersson är det jordbävningsdrabbade ơmrådet tre eller fyra gånger större än det var i februari då sammanlagt 2500 människor beräknas ha omkommit.

Nu har många byar drabbats en andra gång, just när återuppbyggnadsarbetet skulle komma igång. En granskning av 50 byar som FN genomfört visar att hälften av dem var förstörda med 80 till 100 procent.

- Det är oerhört viktigt att snabbt få igång återuppbyggnadsarbetet i god tid före den stränga vintern, understryker Sidney Petersson.

Tiotusentals människor är hemlösa, och många av de nödställda saknar mat för dagen. Det råder också svår brist pá dricksvatten. 


\section{"Vi hjälpte över 100 skadade"}

Malmöbo berättar
från jordskalvens
Afghanistan.
Sy dls v enskitn
Av Bo Göran Dahl $5 / 6-98$

BEKHAHA-DASHTAK. -De

skadade har nu börjat få första hjälpen. I den här lilla byn begravdes nästan hälften av invånarna för några dagar sedan.

Sydsvenskan lyckades igår nå Svenska Afghanistankommitténs Sidney Pettersson i det jordbävningdrabbade norra Afghanistan.

På mobiltelefon berättar han att en tröst i eländet är att hjälpen nu når fram även till de små byarna.

- Men Röda korset och FN har svårt att nå mindre bebyggelse på de branta bergsslutningarna, säger Sidney Pettersson.

Han berättar att de stora organisationernas helkopterpiloter gör heroiska insatser i de otillgängliga trakterna när de flyger in förnödenheter till de drabbade.

Afghanistankommittén har tre rörliga vårdteam $\mathrm{i}$ området. De tar sig fram med terrängfordon. Där det inte går att ta sig fram med fordon hyr man åsnor och hästar av lokalbefolkningen. Ofta får den allra sista biten till de drabbade göras till fots.

Afghanistankommittén driver tre sjukhus och en vårdcentral i Rustaq. Totalt har kommittén sextio-talet läkare, sjuksköterskor och annan personal i det drabbade området.

- Det är ett problem att allt tar sådan tid, säger han. Det tog 4 timmar att ta sig 2 mil till Bekhaha. Färden gick över flera vattendrag som saknade broar.

I Bekhaha bodde cirka 800

människor före jordbävningen. Mer än $300 \mathrm{dog}$. Och de som överlevde var förvånansvärt välbehållna.

- Man kan inte göra mycket åt de döda, utan vi tar oss an de skadade förstảs, säger Sidney Pettersson. Det verkar som om folk antingen avlidit direkt eller överlevt med små blessyrer

Sidney Petterssons team fortsatte i går till byn Dashtak, en timmes färd från Bekhaha.

I byn fanns två moskéer före jordbävningen. En användes som skola. I den dog 140 elever och 6 lärare.

Så sent som igår arbetade folk med att gräva fram döda från den raserade moskén. Några levande förväntas man inte hitta.

- Moskéns golv har hamnat femton meter under marknivån, så det är inte ens tänkbart att man hittar någon, säger Sidney Pettersson.

I Dashtak slog Petterssons team läger för natten. Det hade startat klockan 7 från Rustaq och var i Dashtak klockan 11.

- Läkarna har hunnit ge första hjälpen och behandling åt 102 drabbade på de fem timmarna. Djungeltelegrafen underlättar. Många stoppar oss på vägarna mellan byarna, säger han.

Sidney Pettersson berättar att hans folk arbetat dag och natt sedan i lördags. Hjälpen når folk tidigare nu än i feb-

Sidney Pettersson berättar att hans folk arbetat dag och natt sedan i lördags. ruari då samma område drabbades av jordskalv. Då förstördes 15 byar, 4 000 omkom och 45000 blev hemlösa.

Räddningsarbetet i februari försvårades av dåligt väder som näst intill omöjliggjorde transporter med både lastbil och flyg.

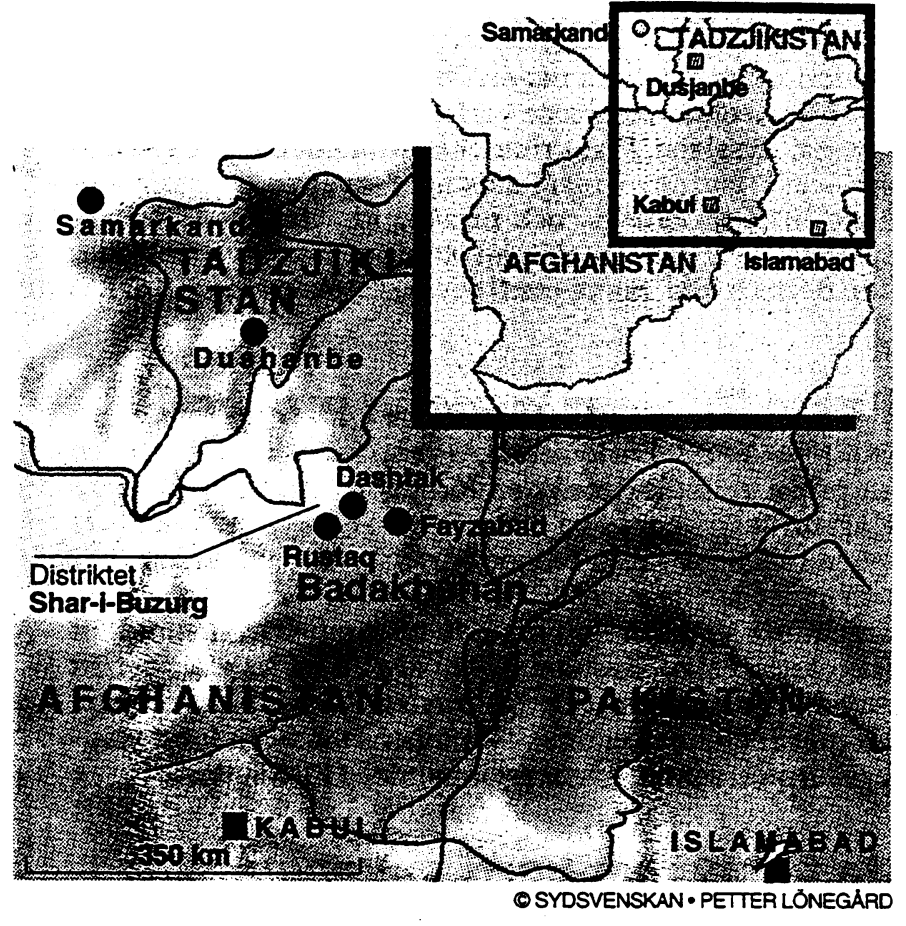

- Vädret är hyggligt nu och området är förskonat från kriget, det underlättar, säger Sidney Pettersson.

De förnödenheter som flygs in med helikoptrar till de drabbade är främst filtar, plast och tält. Men en stor del av den begränsade kapaciteten har hitills gått till sjukvårdstransporter.

FN och Röda korset hyr helikoptrarna i Dushanbe iTadzjikistan. Hittills har organisationerna förfogat över tre helikoptrar. Dessa har dock bara kunnat lasta 3 ton var.

USA har meddelat att det ställer två helikoptrar till FNs förfogande i morgon lördag. Dessa lastar 20 ton var.

Och det är bråttom med större lastkapacitet. Risken för dysenteri, kolera och malaria ökar för var dag som går.

Tiotusentals sover fortfarande utomhus i det värsta drabbade distriktet, Shar-i-Buzurg.
- Vattensituationen kan bli problematisk. Folk dricker det bruna vattnet $\mathrm{i}$ bäckar och åar. brunt och så ska det vara. Den inhemska befolkningen har en annan bakterieflora än vår. Också detta är OK. Men om döda djur hamnar uppströms vågar jag inte tänka på vad som kan hända, säger Sidney Pettersson.

I området, cirka 1800 kvadratkilometer stort, som berördes av skalven levde tidigare cirka 70000 människor. Det är forfarande oklart hur många som dog under skalven. Uppgifterna varierar mellan 3000 och 5000 människor. 60 byar har lagts i ruiner. Ett efterskalv natten till torsdagen ödelade fyra byar i området, enligt FN.

Sidney Pettersson är regionchef för Afghanistankommittén. Efter tvả år i Afghanistan återvänder han till Malmö om 14 dagar.

- Då är jag övertygad om att vi har situationen under kontroll här i norra Afghanistan, säger han. Jorden har färgat vattnet

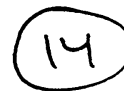




\section{Skalven utlöser jordskred}

\section{Tiotusentals afghaner tvingas sova ute efter jordbävningen}

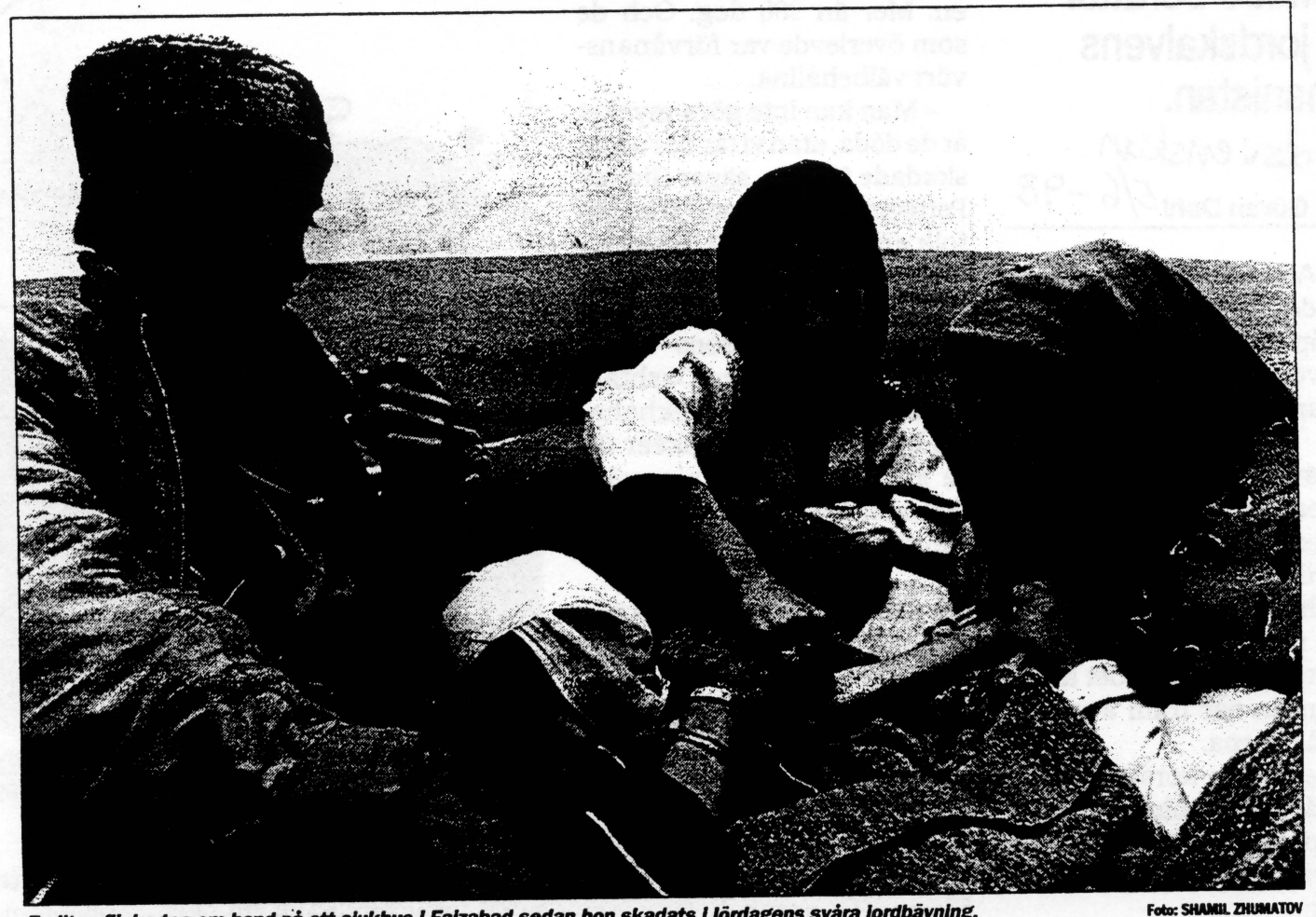

En Ilten filcka tas om hand pá ett sjukhus I Falzabad sedan hon skadats I lördagens svàra jordbävning.

FAIZABAD/TT-REUTERS

- Fut kraftigt efterskalv anställde "allten till torsclagen förödelese ytterligare fyra afghanska byar, meddelar FN. Samtidigt rapporterar Svenska Afghanistankommittén om stora jordskred $i$ katastrofområdet.

Tre rörliga vårdteam från Afghanistankommittén var på torsdagen väg till fots eller med dagen pà văg till hästar och asnor genom väglös trakter till tre byar norr, öste och nordöst om Rustaq. De rapporterar om översvämningar $5 / 6-98$ och stora jordskred. Ett 60-tal läkare, sjuksköterskor och annan personal frăn sjukhus och vărdtraler som kommittén driver på andra platser har skickats in i katastrofområdet.

Nattens efterskalv var kännbara framför allt i Shar-i-Buzurg-området, som anses vara värst drabbat $\mathrm{i}$ den region $\mathrm{på}$ 1750 kvadratkilometer som berördes av den stora jordbävning en i.lördags. Här levde tidigare cirka 70000 människor.

Fortfarande är det oklart hur hus. Deras lastkapacitet är bara många som omkom - uppgifter5000 .

Många får inget att äta

Hjälpinsatserna underlättas nu något sedan USA meddelat at man kan skaffa fram två stora helikoptrar till på lördag. De ka ta 20 ton last vardera. Hittills har räddningsmanskapet bara haf tre helikoptrar, vilka framför allt används till att undsätta skadade $i$ bergen och flyga dem till sjuk- tre ton var.

Hjälporganisationerna är angelägna om att să snabbt som mojjligt kunna transportera mat och vatten och filtar till avsides belägna platser. Det har hittills inte varit möjligt eftersom transporterna av skadade måste prioriteras.

Tiotusentals människor sover fortfarande under bar himmel och en del, i synnerhet i Shar-iBuzurg-distriktet, har inte fătt n̊̊got att äta sedan före jordbävningen $\mathrm{i}$ lördags morse.

\section{- Alla 140 barnen begravdes under jordmassorna}

\section{Skakad svensk hjälparbetare i Afghanistan berättar om följderna av jordbävningskatastrofen}

- Det är fruktansvärt, helt fruktansvärt. 140 barn fanns i skolan när skalvet kom - alla är begravda under jordmassorna och man håller nu på att gräva fram barnkropparna.

Det säger den svenske hjäparbetaren Sidney Pettersson, som befinner sig mitt i katastrofområdet inorra Afghanistan där jordbävningen och efterföljande skred slog till som mest skoningslöst.

Omkring 5.000 människor dödades $\mathrm{i}$ den nya jordbävningskatastrofen i bergslandet och tiotusentals blev hemlösa.

Jag är nu i byn Dachtak, där det bodde 2.500 människor, berättar Sidney Pettersson på en raspig telefonledning från Afghanistan. Pettersson, hemma hörande i Malmö, är sedan tidigare utsänd av Svenska Afghanistankommittén och var med un- der den ännu värre jordbävningen i februari.

- Av Dachtaks 2.500 nvånare räknar vi med att ca 1.500 omkommit i katastrofen. Praktiskat taget hela byn är jämnad med marken och delvis begravd av skred. från bergssluttningarna. Här - Folk máste fá bombat.

Gräver efter kropparna

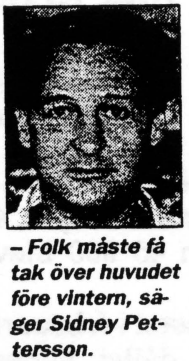
Sidney Pettersson har just anant till Dach ak nar AN just anlant till Dachtak năr AN trots sin erfarenhet är han skakad efter ett besök vid den begravda skolan.

Barnen är det värsta. Här be gravdes 140 ungar och förtvivlade anhöriga gräver nu efter krop parna.

Men det ser trots allt något ljukuta hjälpen börjat fungera. FN sare ut nu än för bara några dagar sedan. - Hjälpsändningarna har börjat komma fram s̊ smått. Men det är fortfarande ont om helikoptrar. Just nu anländer dock ett par helikoptrar med tält och lite mat. Men folk har redan kommit och bett om filtar. Det är visserligen sommar här nu men nätterna är kalla.

Jag skulle vilja påstå att läget är under relativ kontroll. Men det som skrämmer de överlevande är att det då och då kommer nya, mindre jordskalv.

\section{Tuff vinter väntar}

$\mathrm{Nu}$ återstår bland annat den smärtsamma proceduren at identifiera de döda efter han som de kan grävas fram ur skredmassorna.

- Och sedan återstår ett jättejobb med att försöka bygga upp alt igen. Om nor manader ä er från byn massor med raserade hus som tidigare klättrat på bergssluttningarna. Där börjar nu resas tält och provisoriska regn-och vindskydd som flugits in av bl a Röda korset och FN.

- Man kan säga att den första har stora lager längre söderut som man börjat transportera hit. det vinter och folk måste få tak över huvudet. Just nu finns här ingenting. Det blir under alla omständigheter en fruktansvärd tuff vinter för människorna här.

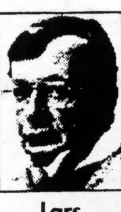

Lars 


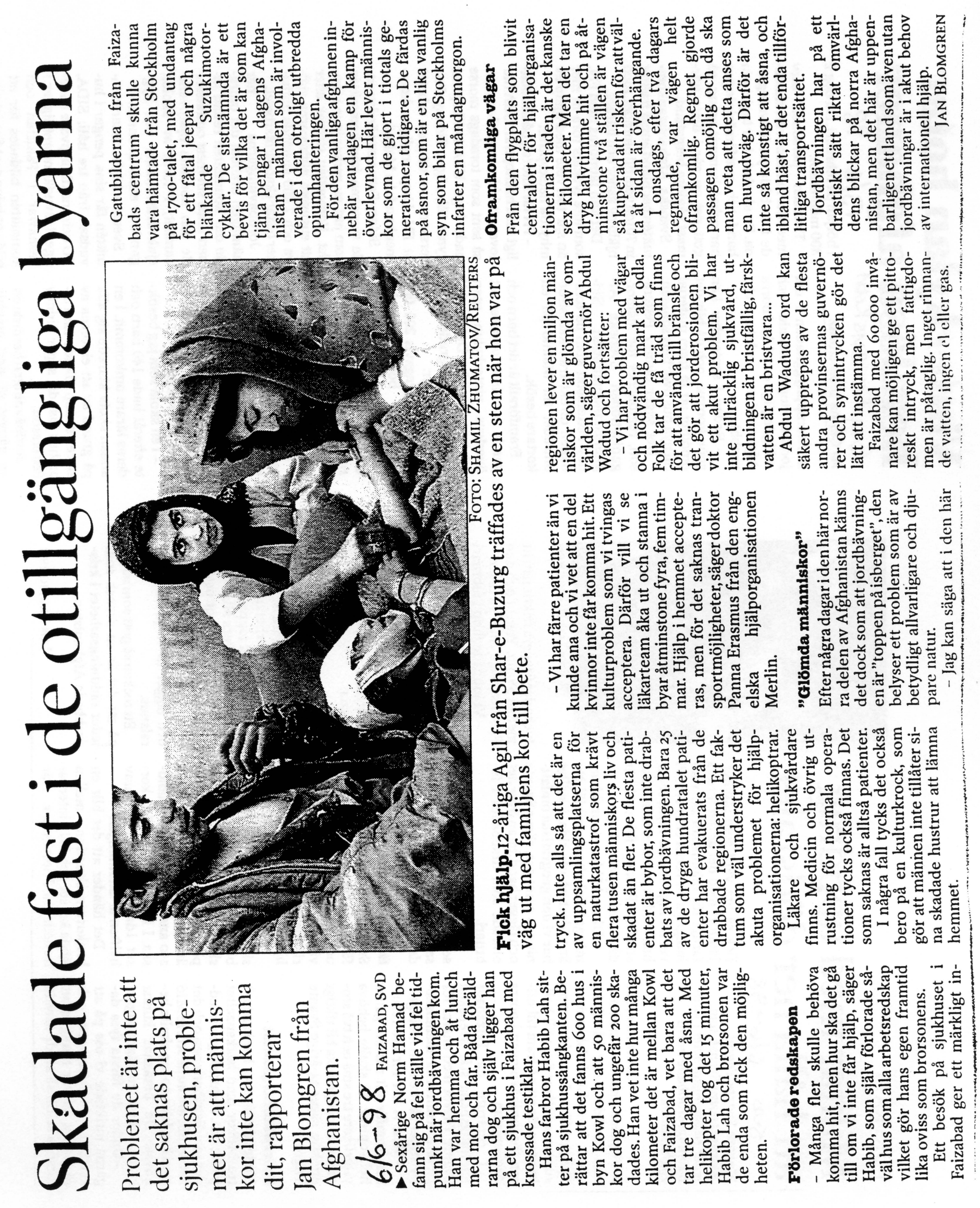



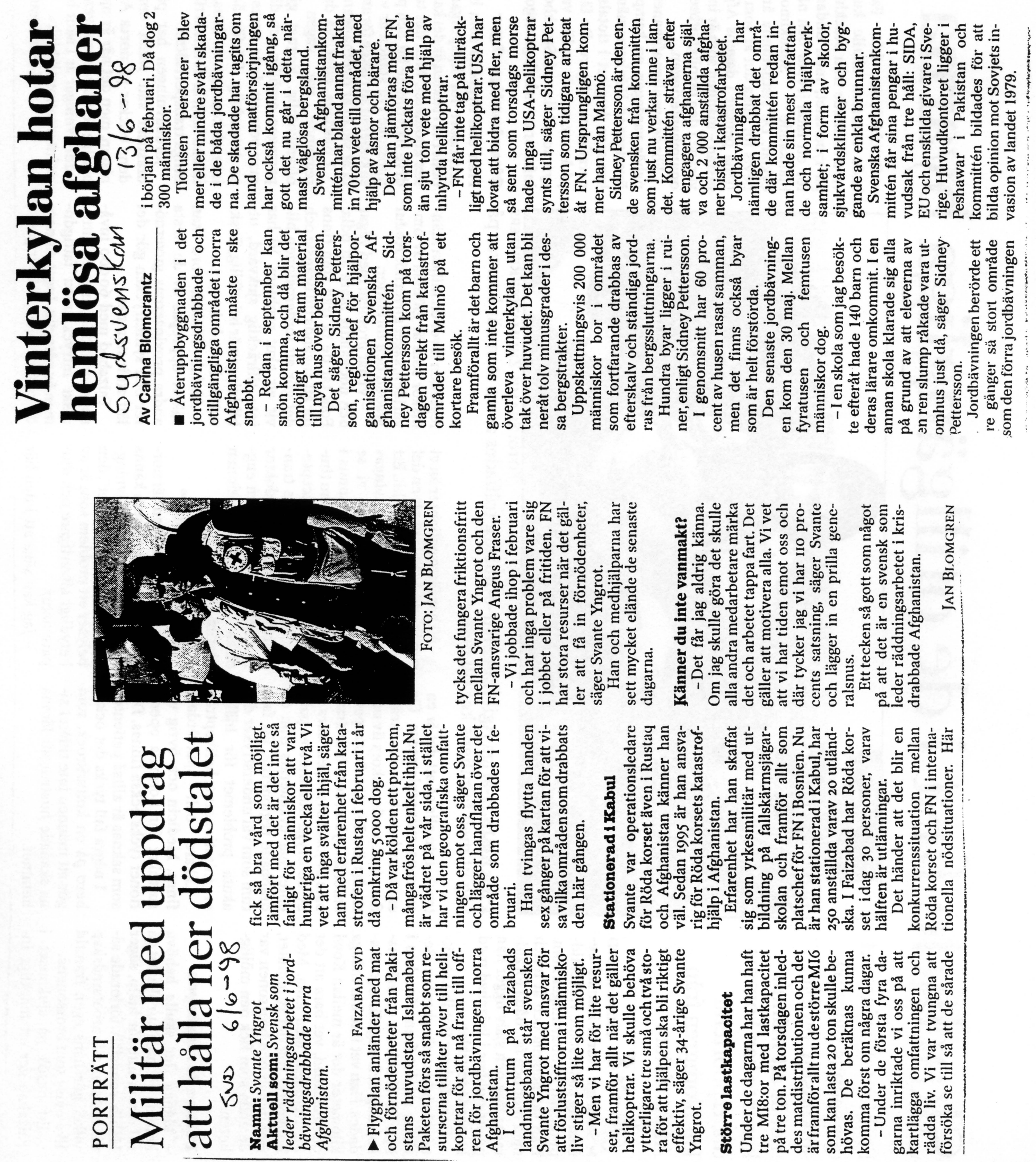

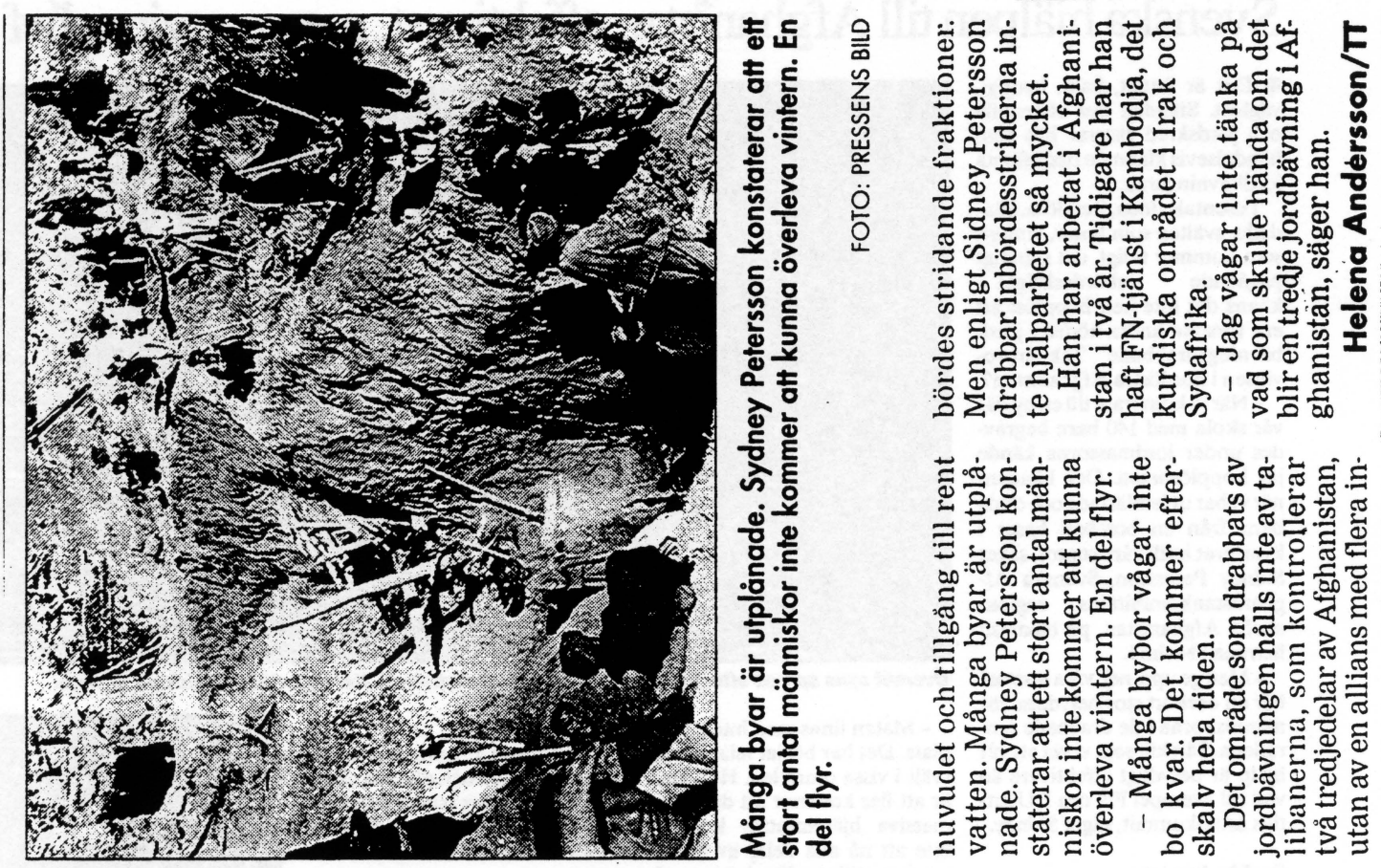

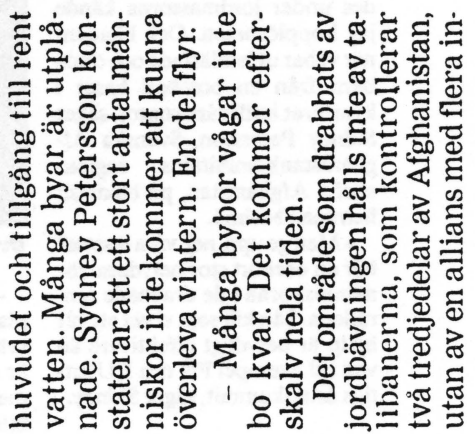

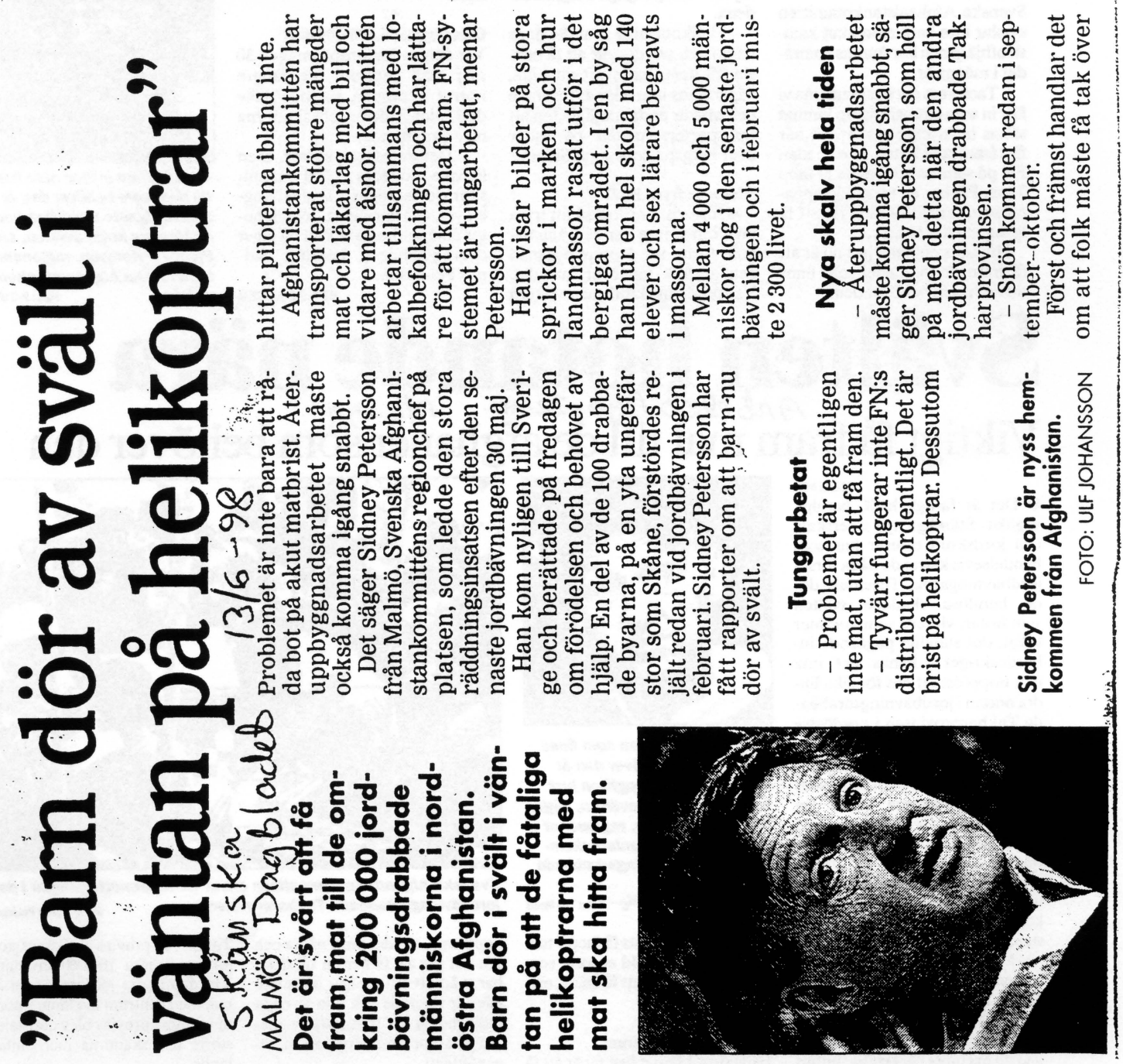




\section{Svenska hjälpen till Afghanistan effektivast, menar regioncȟef}

- Det är fattigt, kallt, bergigt, väglöst. Ständigt nya efterskalv och jordskred raserar hus som händelsevis klarat de båda första jordbävningarna.

'Tusentals döda, hemlösa, skadade, svältten som hotar, vintern som kommer tidigt, det ständigt pågående inbördeskriget känns det inte helt hopplöst att ens försöka lindra nöden $i$ jordbävningsdrabbade Takharprovinsen i nordöstra Afghanistan? - När vi kom fram till en by där vår skola med 140 barn begravdes under jordmassorna kände jag hopplösheten. Och likadant när vi bar ut lemlästade och döda barn från en bombad basar i kvarteret intill vårt kontor, säger Sidney Petersson, Svenska Afghanistankommitténs regionchef i Afghanistan, på blixtvisit hemma i Malmö.

-Men ge upp, nej, våra insatser har en oerhört stor betydelse för människorna i de drabbade om. rådena. Särskilt som vi vet att vår hjälp är betydligt effektivare än vad till exempel FN och EU hittills åstadkommit, säger Sidney.

\section{Snabba insatser}

Svenska Afghanistankommittén sysslar inte bara med akut katastrofhjälp och har funnits i området $\mathrm{i}$ många år.

- Tack vare det har pengarna vi fått in som katastrofhjälp kunnat sättas in mycket snabbt. Vi har fătt fram runt 70 ton vete, medan FN på samma tid lyckats få ihop 7 ton. FN har en tungrodd apparat som tar alltför lång tid att få igång, menar Sidney.

Huvudproblemet just nu är att

få fram de livsmedel som finns till dem som behöver dem.

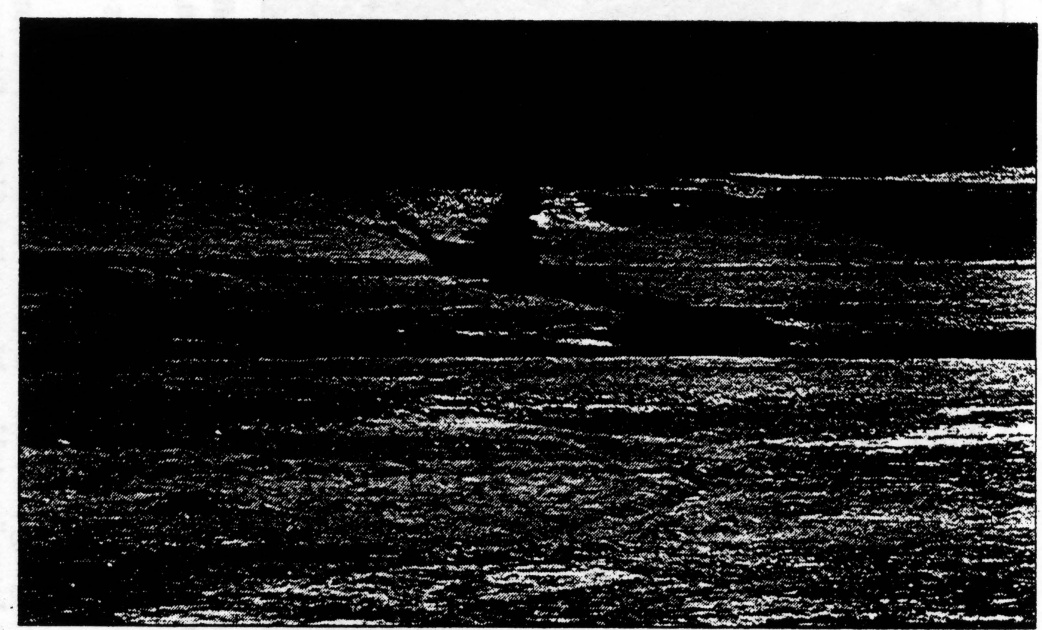

Överallt syns spåren efter jordbävningarna och efterskalven. Här gigantiska sprickor I marken.

- Maten finns men inte på rä̈t kommer tidigt här.

plats. Det har börjat talas om att svält i vissa områden. Helt klart är att fler kommer att dö. Även massiva hjälpinsatser kommer inte att nå alla delar av de här mycket otillgängliga bergsområ dena.

- Helikoptrarna, om det finns några och om det går att få bensin till dem, har svårt att hitta, vägar finns inte eller är raserade och ofta är enda möjligheten att transportera maten på åsnor över bergspassen, säger Sidney.

\section{Riskerar frysa ihjäl}

Mánga riskerar också att frysa hjäl om vi inte kan fă igång någon form av återuppbyggnad och ge folk tak över huvudet. jordbävningen och dödade cirka 2.500 människor i södra delen av Takhar, en provins av Skg̊nes storlek med cirka 200.000 invånare.

\section{Gissningsvis 5.000 dödsfall}

Vid den andra jordbävningen 30 maj med centrum lite längre norrut i samma provins blev dödstalen större och skadorna mer omfattande.

- Det är osäkra siffror, men kanske dödades 5.000 människor vid det senaste skalvet. Ingen vet, det finns inga myndigheter eller andra med koll på läget överhuvudtaget, berättar Sidney Petersson.
I februari $\mathrm{i}$ år kom den första

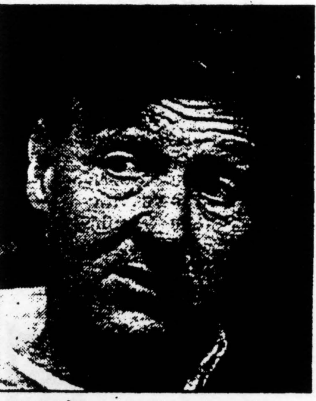

- Att fá fram maten som finns tIII dem som behöver den är den vikt/gaste uppefften Just II Anmars hot Sidnoy Potorsson, roglonchef for Svenska Afghanistankomnu. Annars hotar svïten, säger

\section{Svälten hotande nära}

Anbetet Nyheterna $13 / 6-98$

Viktigt få fram mat till de afghaner som behöver den

Foto: P-O STOUT

MALmó

- Det är fattigt, kallt, bergigt, väglöst. Ständigt nya efterskalv (xh jordskred raserar hus som händelsevis klarat de båda första jordboivningarna. Tusentals dijda, hemlösa, skadade, svälten

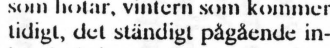
bördeskriget - känns det inte helt hopplöst att ens försöka lindra nöden $i$ jordbävningsdrabbade Takharprovinsen i nordöstra Afghanistan?

- När vi kom fram till en by där văr skola med 140 barn begravdes under jordmassorna kände jag hopplösheten. Och likadant när vi har ut lemlästade och döda barn frăn en bombad basar i kvarteret intill vårt kontor; săger Sidney $\mathrm{Pe}$ tersson, Svenska Afghanistankommittens regionchef i Afghanikommitténs regionchef i Afghani-
stan, på blixtvisit hemma i Sverige stan, på blixtvisit hemma i Sverige. har en oerhört stor betydelse för människorna i de drabbade områ dena. Särskilt som vi vet att vår hjälp är betydligt effektivare än vad till exempel FN och EU hittills åstadkommit, săger Sidney.

Svenska Afghanistankommittén sysslar inte bara med akut katastrofhjälp och har funnits i områ det $i$ mánga år.

- Tack vare det har pengarna vi fătt in som katastrofhjälp kunnat sättas in mycket snabbt. Vi har fått fram runt 70 ton vete, medan FN

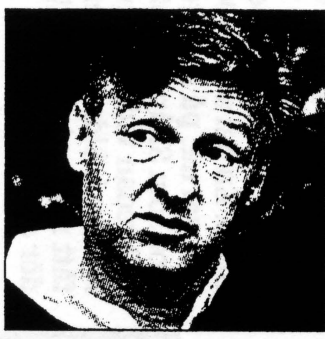

- Att fá fram maten som finns till dem som behöver den är den viktigaste uppgiften Just nu. Annars hotar svälten, säger Sidney Petersson, reglonchef för Svenska Afohanlstankommittén I Jordbävningsdrabbade Takharprovinsen. Foto: T-O Stolt

på samma tid lyckats fă ihop 7 ton FN har en tungrodd apparat son tar alltför lång tid att fă igång, menar Sidney.

Hjälpen nd înte fram

Huvudproblemet just nu är att f fram de livsmedel som finns till dem som behöver dem

- Maten finns men inte på rät plats. Det har börjat talas om svält i vissa områden. Helt klart är at fler kommer att dö. Inte ens massiva hjälpinsatser kommer att nå alla delar av de här mycket otillgängliga bergsområdena:- Heli-

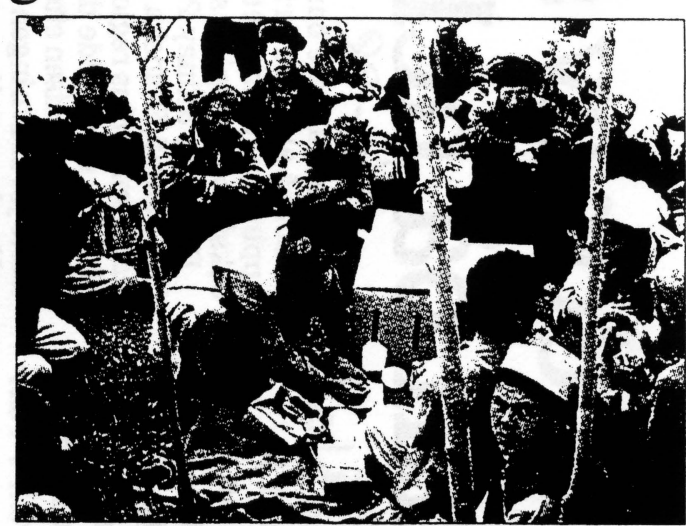

Svenska Afghanistankommittén driver tre läkarmottagningar I den Jordbävningsdrabbado Takharprovinsen.

Foto: Sldiney Potorsso

koptrarna, om det finns några och om det går att få bensin till dem. har svårt att hitta, vägar finns inte eller är raserade och ofta är enda möjligheten att transportera maten på åsnor över bergspassen, säger Sidney.

- Många riskerar också att frysa ihjäl om vi inte kan få igång någon form av återuppbyggnad och ge folk tak över huvudet. Vädret är nyckfullt och vintern kommer tidigt här.

I februari i år kom den första jordbävningen och dödade cirka 2.500 människor i södra delen av
Takhar, en provins av Skănes storlek med cirka 200.000$)$ invånare. Vid den andra jordbävningen 3 maj med centrum lite längre norrutisamma större och skadorna mer omfattande.

Ingen koll pả läget

- Det är osäkra siffror, men kanske dödades 5.000 människor vid det senaste skalvet. Ingen vet. det finns inga myndigheter eller andra med koll på läget överhuvudtaget, berättar Sidney. BENGT SAGER 


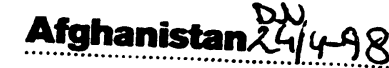

FN-hjälp. FN återupptar tillfälligt sina insatser $\mathrm{i}$ södra Afghanistan och genomför en planerad poliovaccination av barn i omrảdet. FN ska också skicka en styrka för undersöka översvämningarna i landets sydvästra delar.

T-Reuters

\section{Talibanerna kom inte till fredssamtal ${ }_{2614}^{\mathrm{D}} / 48$}

AFGHANISTAN. De afghanska fredssamtal som skulle inledas i Pakistans huvudstad Islamabad pả lördagen kom inte i gâng pả utsatt tid. Anledningen var att talibanmilisens delegation inte fanns pá plats. Samtalen ska föras under överinseende av FN och Islamiska konferensen, OIC. Under lördagen träffades parternas samordnare hos FN:s specialorgan för Afghanistan, Unsma, för att försöka enas om en ny tidtabell.

Talibanmilisens förhandlare väntades till Islamabad under lördagen i stället för fredagen, men inga samtal troddes komma i gång före söndag. Varför talibanerna inte kom pâ utsatt tid kunde varken FN-representanter eller pakistanska tjänstemän säga. Afghanska källor uppgav dock att talibanerna, som behärskar cirka två tredjedelar av landet, har invändningar mot de frágor som oppositionen tänker ta upp.

En niomannadelegation frán oppositionsalliansen som har sina baser i norra Afghanistan kom till Islamabad i torsdags. Oppositionen har sagt att man inte bara vill diskutera vapenvila och fångutväxling utan även politiska frågor som maktdelning. Det tros vara den sistnämnda frảgan som den islamistiska talibanrörelsen blivit upprörd över.

Tusentals afghaner har stupat i striderna mellan olika muslimska rörelser i Afghanistan efter kommunistregimens fall 1992. Motsättningarna inom det afghanska samhället är sáväl etniska som religiösa och politiska.

TT-AFP

\section{Fredssamtal om Afghanistan ${ }_{207}^{509} 498$}

Islamabad: Efter att ha anklagat varandra för nya militära fientligheter satte sig representanter för de afghanska talibanerna och oppositionen vid förhandlingsbordet på söndagen för att diskutera vapenvila, fångutväxling och nödhjälp till hungrande.

Mötet hålls i grannlandet Pakistans huvudstad Islamabad. Medlare i samtalen är FN och Islamiska konferensen, OIC.

Båda sidor uttalade fredsappeller och chefdelegaterna kramade om varandra, därtill uppmanade av den pakistanske utrikesministern, innan de försvann in i slutna förhandlingar. Samtalen väntas pågå i upp till fem dagar.

I lördags kom rapporter om hårda strider vid en av frontlinjerna ett par mil norr om huvudstaden Kabul som av invånare i området beskrevs som de hårdaste på nio månader.

Parterna tycks beredda att diskutera en permanent vapenvila och att utväxla fångar, och medlarna hoppas få talibanerna att häva sin blockad av provinsen Bamiyan i det av shiamuslimer dominerade centrala bergsområdet Hazarajat. Där lider flera hundra tusen människor svår nöd efter att i åtta mảnader knappt ha kunnat få in några förnödenheter och skördarna har slagit fel. TT-REUTERS

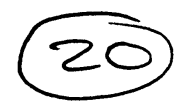

\section{Afghanska fredssamtal avbröts}

Islamabad: De krigförande parterna i Afghanistan avbröt sent på måndagen fredssamtalen för konsultationer med de högsta ledarna på respektive sida, sade källor vid fredssamtalen i Pakistans huvudstad Islamabad. Knäckfrågan är vem som ska leda en kommission med islamiska skiftlärda vars uppgift blir att avsluta det 18 år långa inbördeskriget.

De strängt islamiska talibanerna som kontrollerar två tredjedelar av landet inklusive huvudstaden Kabul och oppositionsalliansen $\mathrm{i}$ landets norra del kunde under måndagsmorgonen dock enas om en dagordning som innefattar bildandet av kommissionen med ulema, det vill säga skriftlärde. På dagordningen står dessutom vapenvila, frigivning av fångar samt hävande av blockaden i Hazarajat i landets mellersta de. TT-AFP SUD $9.814-98$

\section{Fredssamtal på väg haverera}

AFGHANISTAN. Det var pả lördagen osäkert om det blir nảgon fortsättning pả förhandlingarna om fred i Afghanistan. Talibanerna meddelade att deras delegation, som ảtervände till Kabul i torsdags för att rådgöra med sin regering, inte skulle komma tillbaka till $\mathrm{Pa}$ kistan på söndagen.

Fredsförhandlingarna i Pakistans huvudstad Islamabad har redan frản början gått trögt, bland annat pá grund av oenighet om den kommittê av islamiskt lär. da, "ulema", som skall fortsätta förhandlingarna efter den inledande fasen.

När förhandlingarna avbröts i torsdags gällde oenig. heten oppositionens krav pâ att de styrande talibanerna skulle upphäva sin blockad av det centrala höglandet, Hazarajat. DAJ $3 / 5-98$ TT-AFP

\section{Afghaner avbröt fredsförhandlingar}

Islamabad: Fredssamtalen i Afghanistan bröt samman på söndagen efter bara två timmar. Oppositionen från norr lämnade samtalen när talibanernas ende representant vägrade att förhandla om făngutväxling och att häva blockaden av handelsvägar. Oppositionen var speciellt angelägen om att ta upp talibanernas blockad av Hazarajatområdet, där människor nu rapporteras svälta ihjäl. Den afghanska nyhetsbyrån AIP sade på söndagen enligt DPA att båda sidor redan uppmanat sina stridande enheter att förbereda sig för nya slag. AP, TT-REUTERS S, $4 / 5-58$

\section{Talibanerna inledde offensiv}

Islamabad: Taliban-milisen i Afghanistan inledde på tisdagen en storoffensiv i landets nordöstra del i provinsen Takhar, uppgav nyhetsbyrån AIP som arbetar i östra grannlandet Pakistan. Offensiven kom bara två dagar efter det att fredssamtalen med oppositionsalliansen bröt samman i den pakistanska huvudstaden Islamabad.

Enligt AIP gick de islamiska krigarna till angrepp med artilleri och raketer i Bangiområdet. Det hette att tio posteringar hade erövrats frản styrkor under befäl av oppositionsledaren Ahmed Shah Massoud.

Striderna sades ha orsakat stora förluster på båda sidor, eftersom Massouds välbeväpnade styrkor gick till hårt motangrepp.

Det fanns inga oberoende källor som kunde kommentera saken, men enligt en talesman för oppositionen, som bekräftade talibanernas attack, försyarade sig Massouds styrkor med stor intensitet. TT-AFP $6 / 5-97$ SW 


\section{Talibaner intar oppositionsfäste}

ISLAMABAD. Den strängt muslimska Talibanmilisen i Afghanistan har erövrat det strategiskt viktiga Ishkemishdistriktet från oppositionsstyrkor i landets norra delar. Oppositionsstyrkor under general Ahmed Shah Massud tvingades dra sig tillbaka österut, uppgav den afghanska nyhetsbyrån AIP på fredagen.

De regerande talibanerna kontrollerar 80 procent av landet och den senaste offensiven betyder att oppositionen förlorar ett viktigt fäste och Massouds armé, med högkvarter i Panjsjirdalen, står utan förbindelsevägen till provinshuvudstaden TaloqSan.

Efter förra veckans sammanbrott i fredsförhandlingarna mellan Talibanerna och flera fraktioner inom oppositionen blossade inbördeskriget upp med full styr. ka i mándags. DJj $9 / 5-98$ TI-DPA

\section{Nietso $18 / 5-98$} Talibanskt stridsflyg angriper mål i norr

AFGHANISTAN Talibanskt stridsflyg angrep i går en stad i norra Afghanistan. Minst 30 människor dödades och 50 skadades vid flygangreppet mot marknadsplatsen i staden Taloqan, uppgav oppositionskällor.

Taloqan är huvudstad i provinsen Takhar och ett fäste för den avsatte presidenten Burhanuddin Rabbani.

En talesman for Rabbani, Mohammed Arif, uppgav att flygräderna pägick under hela gårdagen.

Talibanernas Radio Shariat uppgav att stridsflyget angripit militära posteringar i norra delen av landet.

Talibanerna kontrollerar cirka 85 procent av landet.

(AP) i Pakistan.

\section{Oppositionen} inledde offensiv

AFGHANISTAN. Oppositionen i Afghanistan inledde på fredagen en offensiv mot de styrande talibanerna i norr. En allians av olika oppositionsstyrkor under general Ahmad Shah Masood återtog omrảden i Baghlanprovinsen i norr som erövrades av talibanerna i torsdags. Uppgifterna kom från en talesman för Masood som uttalat sig för den islamiska afghanska nyhetsbyrån AIP.

Talibanerna hade dock fortfarande skurit av en viktig försörjningsväg för oppositionen, sade både $\mathrm{Ma}$ soodtalesmannen och oberoende källor i huvudstaden

Kabul.

Den strängt muslimska ta ibanrörelsen kontrollerar mer än två tredjedelar av landet, inklusive Kabul som intogs i september 1996. PN 16/5-97 T-Reuters

\section{Raketanfall môt Kabul}

Kabul: Fyra personer dödades och flera skadades när raketer på söndagen slog ned i Kabul, i ett av de värsta anfallen mot den afghanska huvudstaden på närmare ett år. Enligt ögonvittnen var det minst tio raketer som träffade staden på förmiddagen. Två av dem träffade flygplatsen, som används för både civila och militära ändamål. Andra träffade ett tätbefolkat bostadsområden i Kabuls sydöstra utkant.

Raketerna avfyrades av den oppositionsallians som kämpar mot talibanregeringen. Alliansen har sagt att man kommer att fortsätta att beskjuta främst flygplatsen så länge talibanerna använder den för sina stridsflygplan som anfaller motstảndarens ställningar. AP ธ́ 25 29/6-98

\section{Talibaner slår igen filickskolor DN $16 / 6-98$} KABUL. Den talibanska armén stängde pá tisdagen mer än 100 privatskolor som i det tystá brutit mot förbudet att lảta flickor gå i skolan.

Talibanernas religionsminister tillkännagav stängningarna i den belägrade huvudstaden $\mathrm{Ka}$ bul, och tillade att de som bryter mot förbudet att utbilda flickor kommer att straffas.

En enkät i januari visade att det fanns minst 107 skolor med kvinnliga elever i Kabul. mer att påverka all lokal verksamhet för flickor och kvinnor, sade en hjälparbetare som ville vara anonym.
- Den här regeln kom-

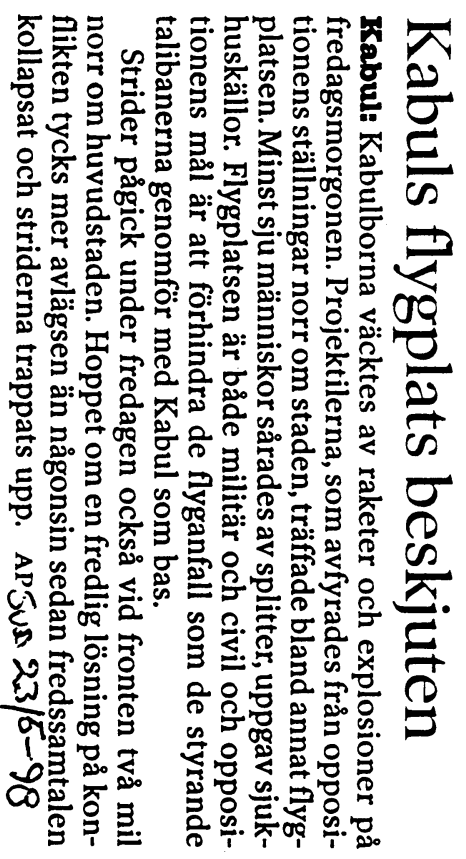

4800 kronor till jordbävningoffer

Det har varit ett enormt gensvar pả Svenska Afghanistankommitténs (SAK) upprop om hjälp till jordbävningskatastrofens offer i Norra Afghanistan.

Via kommitténs insamlingskonto har under kort tid influtit drygt 1.5 miljoner kronor. Genom Skövdekommittén kan nu redovisas 4785 kronor från de insamlingsbössor som varit i omlopp. I ett nyligen anlänt brev från de äldres råd i den olycksdrabbade regionen uttrycks ett varmt tack till svenska folket for en direkt och livräddande insats under katastrofen.

SAK går nu in i en våroffensiv för krigets offer! Den gångna vintern har varit en av de värsta i mannaminne.

- Tiotusentals människor har tvingats fly undan fortsatta strider mellan olika beväpnade fraktioner.

Den sk talibanmilisen blockerar sedan mer än ett halvår centrala Afghanistan och tillåter ingen inforsel av livsmedel och andra livsnödvändigheter till be- finner sig hundratusentals människor på randen till svält.

- Frán huvudstaden Kabul rapporteras om en växande misär bland fattigfolk och många människor, inte minst många kvinnor och barn, tvingas i sin desperation till tiggeri.

Samtidigt som civilbefolkningen befinner sig i en ytterligt svår situation fortsätter de väpnade fraktionerna att kapprusta för nya strider. Under våren när kylan äntligen börjar släppa sitt förlamande grepp över stora delar av landet räknar internationella bedömare med att krigshandlingarna kommer att trappas upp på nytt.

Nytt mänskligt lidande och nya flyktingvågor kommer att skapas inom landet. För många utgör de internationella hjälpinsatserna det sista hoppet om överlevnad.

De fattigaste av de fattiga och mest utsatta får helt enkelt inte glömmas bort! SAK är en av de få hjälporganisationer som i dag har en bred verksamhet (utbildning, hälsovård, dricksvattenprojekt etc) över stora delar av den afghanska landsbygden och som har en långvarig erfarenhet av att bedriva hjälparbete unde svåra omständigheter. 


\title{
Afghanistan Svenska Journalen $15 / 5-98$ Solugnen - en solklar lösning
}

\author{
- Nöden är uppfinningarnas mo- \\ der. I inbördeskrigets Afghanistan \\ är det svårt att få tag på bränsle till \\ matlagning. Men det finns gott om \\ solsken. Lösningen blev: solugnar! \\ $\mathrm{Nu}$ är Läkarmissionen med och \\ stöder ett arbete där man sprider \\ kunskap om hur ugnarna byggs. \\ Det är framför allt i de stora \\ flyktinglägren vid Sar-shahi utanför \\ Jalalabad, som matlagningen är ett \\ problem. Hit flydde folk undan \\ striderna i Kabul, huvudstaden. \\ Ett problem är dock att Taliba- \\ nerna inte tillåter kvinnor att arbe- \\ ta utanför hemmet. Tidigare sköt-
}

\section{Afghanistan}

\begin{abstract}
tes utbildningen av kvinnor som åkte runt och visade andra kvinnor.

Men kanske, säger Bruce Clark, som arbetar på hjälporganisationen SERVE (en ekumenisk organisation som är samarbetspartner till Läkarmissionen) finns det nu en stråle ljus även när det gäller detta.

- Vi bïöd Talibanledare i området runt Jalalabad pả en máltid. De blev mycket imponerade och entusiastiska. Så kanske de kan se mellan fingrarna när det gäller det-
\end{abstract}

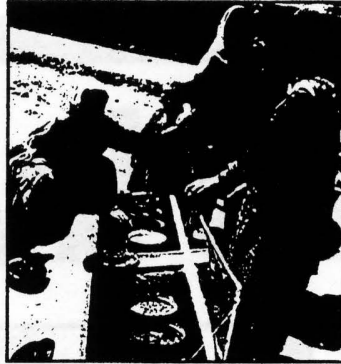

Solugnen - en uppfinning som blivit till stor glädje för af-

För första gången på ett år görs på lördag ett nytt försök att få igång fredsförhandlingar om det våldsdrabbade Afghanistan. Kriget i landet har pågått utan avbrott sedan 1979.

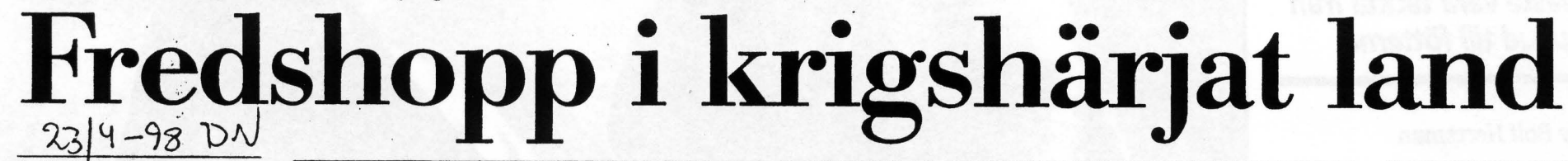

Av Mats Lundegård

Plötsligt ser det ut som om fredsprocessen vaknar i det krigshärjade Afghanistan dande parterna i konflikten för första gången på ett å sätta sig víd ett fơrhand lingsbord, uppger FN. För en vecka sedan förklarade USA:s FN-ambassadör Bill Richardson efter ett blixtbe sök i Afghanistan att ett genombrott har inträffat. Samtalen sker i FN:s och den is-
lamiska konferensens (OIC) regi.

Afghanistan är ett av de mest krigshärjade och utarmade länderna i världen. Se dan början av sjuttiotalet har landet hemsökts av kri och våld. Sovjet invaderad kandet när den kommunistiska regeringen i Kab)

Tio år senare tvingades Moskva dra tillbaka sina Moskva dra tillbaka sina mjukade och besegrade. De ansatser till infrastrukturer som under artiondena tidigare byggts upp hade dả ơdelagts fullstandigt och en befolkning hade tvingats fly.

Den fred som vărlden möjli gen hoppaces på efter Sov jets atertag gackades emestått eniga mot de sovjetisk ockupationsstyrkorna misslyckades fullständigt med at enas om ett fredligt uppbyggnadsarbete. I stăllet för att samarbeta drogs de olika partierna och etniskt baserade gerillabanden i landet stället in i ett inbördeskrig som efter olika förvecklingar pågår ănnu i denna dag. Grova uppskattningar säger att kanske femtiotusen män niskor fătt sătta livet till denna blodsutgjutelse

Talibanerna, den ursin nigt ortodoxa islamistiska gerillan som med stöd av $\mathrm{Pa}$ kistan frán 1994 började t over all stơrre områden södra Afghanistan är i da den absolut dominerand makten $\mathrm{i}$ lande

De fostrades i koranskolor flyktinglăgren i Pakista under åren då Sovjet ocku perade deras hemland. D var ursprungligen alla etnis ka pathaner, hemma i had norra Paki-stan och angränstan pros ider cade religion präglas av wa gade religion praglas av waSaudiarabien - som for ö rigt finaniser som talibanernas fost-ran den har ockss lokala tradi

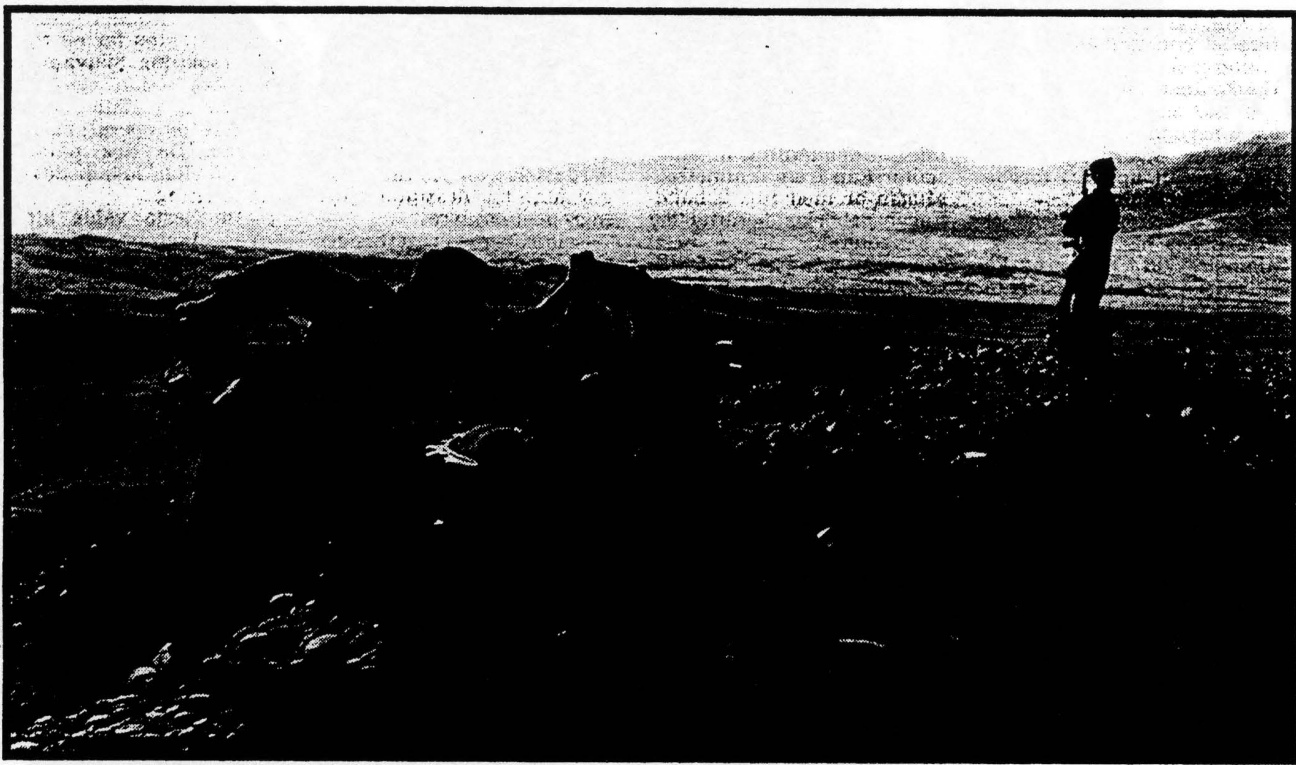

Afghanistans blodiga historia

1919: Afghanistan oberoende 1963: Kvinnlig rösträtt till parfràn britterna efter tre krig. Under lamentsval införs. kung Amanulla fâr landet sin för ta forfattning och ett modem cke-religiöst, răttsväsen.

1929: Amanulla drivs $i$ landflykt efter ett uppror.

1933: Mohammad Zahir blir kung efter en tids oreda.

1953: Kungens kusin Moham mad Daud blir premiärministe och paskyndar modemiseringarna med bl a sovjétiskt stöd.

1963: Daud avskedas och

viss demokratisering följer.

\section{Talibanerná} eptember 1996. De behä skade sá dags runt tre fjärdedelar av Afghanistans te ritorium. Oppositionen mo dem organiserade sig i en los koalition som formellt leddes av den forre présidenten Burhanuddin Rabbani.

Motstándarna dominerades emellertid militärt av en ore detta kommunistisk ge neral, uzbeken Abdel Rashic Dostum och den tadjikiske gerillaledaren - en gang najon - A n Grupen finns tisk min ritretrader ma i centrala idelarma

1973: Kungen störtas efter missyüt och hungersnöd av Daud. Han utropar republik och sig själv som president. Försoker diktatoriskt utveckla landet

1978: Daud mördas i en blodig militarkupp och kommunisterna kommer till makten. Nur Mhammad Taraki blir presiden att genomföra en jordroform alfabetiseringskampanj utloser beväpnade protester.

1979: Taraki störtas och mördas. Sovjet invaderar. Barak Kar mal görs till president. Ett långt krig börjar. Mer än tre miljoner manniskor flyr till Pakistan och

- 1986: Karmal ersätts av Naiibullah, som väljs till president 1987.

1989: Sovjet drar sig ur men kriget fortsätter. Najibullah tar ett fastare tag om makten i Kabul.

- 1992: Islamiska gerillan tar makten och Najibullah tvingas avgá. Inbördeskriget fortsätte

dersakare i norr har i me an arton mánader varit in dragna i ett krig om mak och territorium. Fronterna geografin skiftar liksom också allianserna mellan lokala ledare. En tid intog talibansk gerilla rentav MazarSharif, centralorten i den enklav som oppositionen haft kontroll över. Staden har se dan âtertagits av oppositio

Talibanernas styre, fram for allt deras hárt diskrim. nerande särbehandling a kvinnorna i Afghanistan ha vallat en storm av internaminister har kallat deras re gemente "avskyvärt" och fö en månad sedan drog sig en manad sedan drog si landet efter en kontrovers

med "den heliga gerillan" Men mycket talar for att ta loanerna också infort vis okala gerillaledare i åratal ofredat civilbefolkningen e ter eget gottfinnande.

Diskrimineringen av kvinnor har också slagit mycket olika. De som drabbats hårdast ar Kabuls medelklasskvinnor som under en period kunnat átnjuta utbildnin och vasterlandska friheter. For befolkningen i isolerade byar har talibanernas ord inneburit nagot omstörtande nytt.

mella talibanerna och de oppositionella i norr ar knappast helhandlar i stället om etniska
1995: Talibanerna, unga aganska män frản islamiska skolor i Pakistan erövrar staden Kandahar och flera provinser $i$ söder. En lös koalition av de gerllafraktioner som tidigare bekă mot den islamistiska morllan.

1996: Talibanerna tar öve Kabul, hänger Najibullah och förklarar Afghanistan för en helt islamisk stat. Oppositionen tvingas retirera norrut.

1998: I dag behärskar taliba nerna cirka $85 \%$ av Afghanistan.

konflikter som dessutom ma nipulerats av grannländer och än mer avlägsna intres senter. Pakistan har frản borjan stött olika pathanska grupper och på sistone talibanerna. I bakgrunden har räckning politiska hand-

Amerikanernas intresse var ursprungligen att stödja alla som satte sig upp mot Sovjets ockupationstrupper men på senare tid har konflikten mellan USA och Iran ocksâ aterspeglats i politiken i Afghanistan.

Iran har i alla ár haft in tresse av att bispringa sina religionsbröder, shiiterna

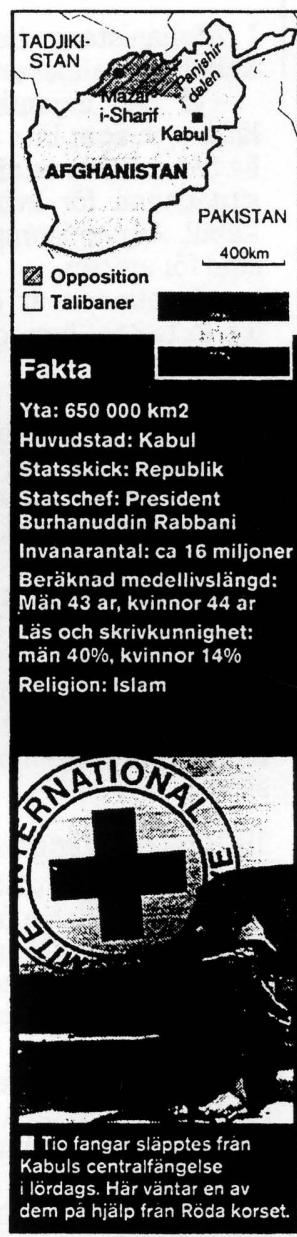
stånd från USA. landet - och dessutom alltsá, i hjulet for USA:s allierade Pakistan. De nya centralasiatiska republikerna norr om Afghanistan - framför allt har stött den mot talibane na fientliga koalitionen. Det har de gort for att de oroat over granserna och destab. lisera de skakiga regimern. men ocksá av etniska lojali Ryssland

( Intresset for Afghanistan ar geopolitiskt; alla frukta det finns ocksa framtida eko. nomiska intressen som spe lar in. Företag inom den in ternationella energiindusoljeledningar kan dras öve trin skissar på hur gas- och 


\section{I krigets Kabul är det kvinnorna som lider mest. De får inte gå ut ensamma och de måste vara täckta från huvud till fötterna}

\section{Av Rolf Hertzman}

I Afghanistans huvudstad Kabul styr talibanerna.

- VI har ingenting kvar längre, vi äger inte ens våra liv. Så beskriver en afghanska situationen för kvinnorna i Kabul, Afghanistans huvudstad för avisen.

- Situationen är outhärdlig, fortsätter hon, det finns inga utvägar.

Talibanema, den religiösa milis som styr två tredjedelar av Afghanistan, har utfärdat en stor mängd påbud. De gör kvinnorna till fångar, både fysiskt och psykiskt.

Bara några timmar efter det att talibanerna hade intagit Kabul den 27 september 1996 kom det första förbudet: inga kvinnor fick arbeta, de fick inte heller gå i skola

\section{0 utestängdes}

Med ett slag utestängdes över 100000 flickor från vanlig skolgång. Över 8000 kvinnliga lärare, vilket är 70 procent av lärarkåren, måste sluta arbeta.

Dessutom stängde talibanema 32 offentliga badinrättningar för kvinnor. Det skedde i en stad som till största delen låg i ruiner, där vatten och el knappt fanns, där ved var en bristvara även för de fåtal som hade råd att köpa den. Och det skedde strax innan vintern kom med isande kyla.

Greppet om resten av landet är inte lika hårt som över huvudstaden.

Där har situationen förvärrats för alla men mest för kvinnorma. De får inte längre gå ut på gatoma om de inte är helt täckta av ett tygstycke, burqa, och går till-

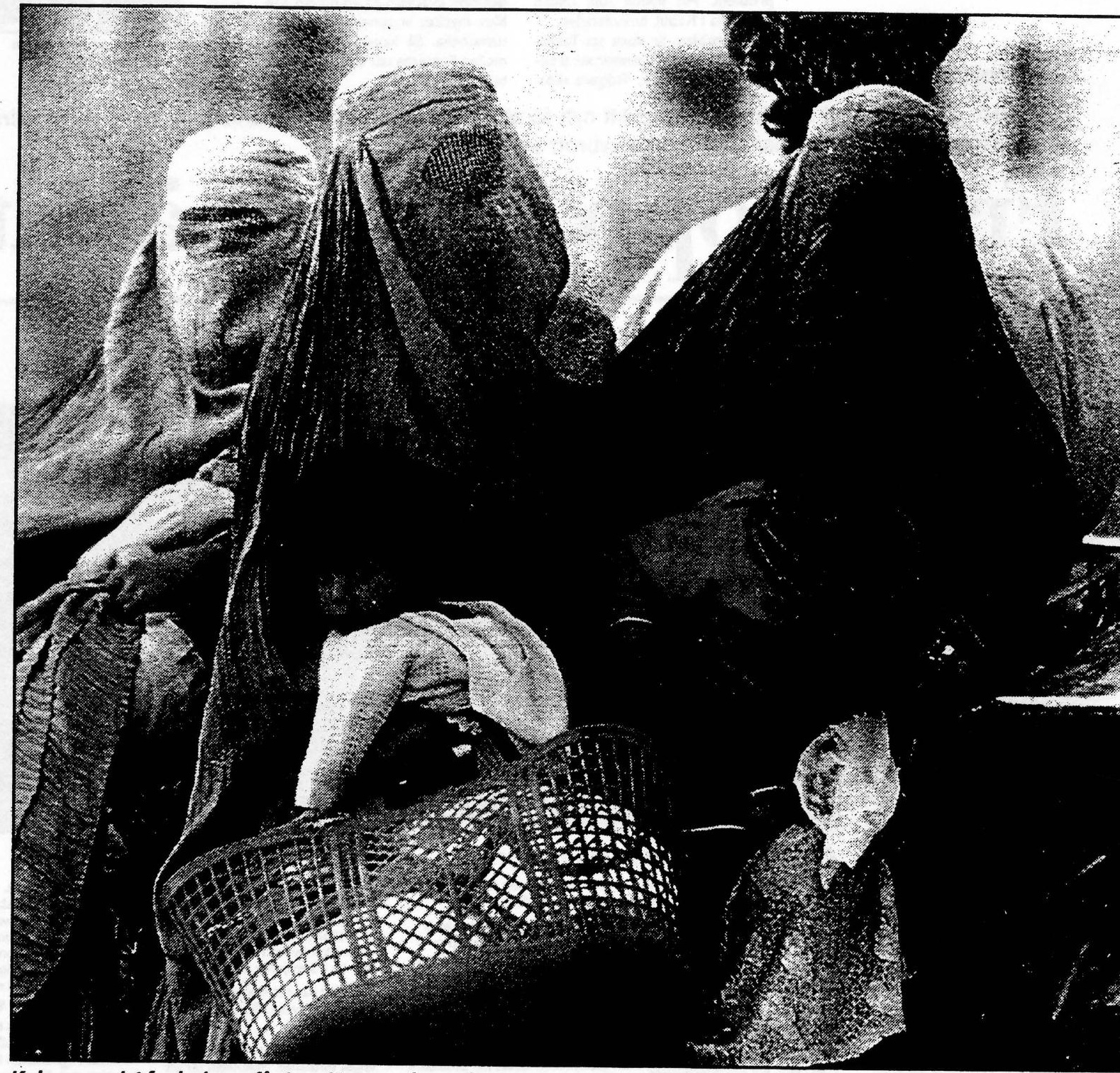

Kvvinnorna i Afgahnistan får inte längre gå ut på gatorna om de inte är helt täckta av ett tygstycke, burqa, och går ti mans med en manlig släkting sedan talibanerna intog huvudstaden Kabul för ett och ett halvt àr sedan.

sammans med en manlig som man säger sig vilja bygsläkting.

Änkor och ensamstående kvinnor måste hålla sig inomhus. De har därmed berövats även den sista möjligheten att få ihop till livets nödtorft, den som heter att tigga.

\section{Slå med vajer}

Talibanerna säger sig värna om kvinnans dygd, hon ska inte vara ett könsobjekt som hon har blivit i västvärlden.

Det är en ren islamisk stat ga, den kommer att styras efter de stränga sharialagarna.

\section{Lagar utan stöd}

Men talibanerna utfärdar även lagar $i$ islams namn trots att det inte finns stöd för dem i Koranen eller i sharialagarna. Tre länder har erkänt Afghanistan under talibanerna: Pakistan, Förenade Arabemiraten och Saudiarabien. De stöder med både pengar och vapen.
Den kvinna som ertappas med målade naglar kan få fingertoppen avhuggen direkt på gatan.

Att slå på kvinnor med elkablar är inte ovanligt. Kvinnoma ska förödmjukas, hela familjen bryts ned. Den man som försöker försvara sin hustru straffas, kanske dödas han.

- I ett krig lider alla, unga som gamla, säger afghanskan. Men det är kvinnorna som får lida först och det är kvinnoma som lider mest.
Foto: Pressel 


\section{Reportage}

FN-beslut

satte fart

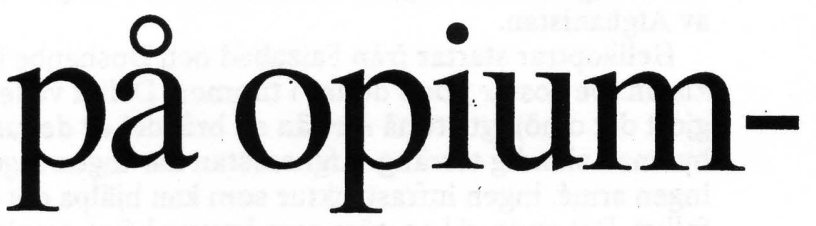

odlingen

\section{Tidigare svenskt projekt i Afghanistan är nu blomstrande vallmofält}

PESHAWAR I PAKISTAN - För tjugo år sedan kallades det "Little America".

Det var den gröna revolutionens vagga i Afghanistan innan den sovjetiska Röda armén tågade in och landet förtärdes av krig som förvandlade den bördiga jorden i Kama några mil öster om Jalalabad till en ofruktbar halvöken.

När Svenska Afghanistankommittén (SAK) med hjälp av Sida 1992 satsade några miljoner kronor på ett återuppbyggnadsprojekt som skulle få bygden att återigen blomstra och ge levebröd åt 50.000 hemvändande flyktingar så fanns det bara ett villkor.

- Visa till myndigheter och bönder att vi skulle dra oss ur om vi hittade en enda opiumvallmo i området och alla såg till att det bara fanns matgrödor under de år som insatsen tog, berättar Anders Fänge, SAK-ansvarig i Peshawar.
I dag, just som ni läser det här, skördas tonvis av opium i Kama av tusentals barn och vuxna som samlar in de sista klimparna av växtsaft från de mognande frökaps-

Plötsligt odlar alla bönderna opium och under blomningstiden för fyra veckor sedan var hela bygden ett hav i vitt och rosa.

\section{Ryktets fel}

Ingen skugga faller över SAK och Sida Alla jag talar med skyller i stället på "ryktet".

- Bönderna säger att de fick höra från granndistriktet att FN:s antidrogprogram UNDCP, lovat betala alla som odlade opium för att de skulle gå över till en annan groda, säger Sidney Petersson, malmöi som jobbat åt SAK i Afghanistan i två å

Alltså bọrjadealla med vallmo fơr att fá FN-pengar.. och är väl förtrogen med området.

\section{Fakta}

$\checkmark$ Den globala narkotikahandeln uppskattas av UNDCP ill 3,500 miljarder kronor, â lika stor som oljehandeln och uppgär till sju procent av vänds shandeln.

92 procent av allt ráopium i vărlden produceras $i$. Atǵnanistan och Buma

Drygt 80 procent av alt heroin som beslagtas I Europa kommer frản Afghanistan.

Det hittills stôrsta beslaget I Pakistan gordes nnảra Peshawar 1995 dá polisen stop

pade en lastollskaravan med $165.000 \mathrm{~kg}$ cannabis och $480 \mathrm{~kg}$ heroln.

Cirkia 52 procent av cte atonsto

tan medan rosten

Skörden per hektar varierar mellan $25.75 \mathrm{~kg}$ och kilopriset a r 200 gánger hógre ân

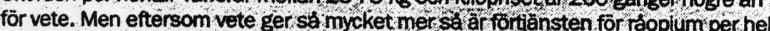

tar bara dubbeltsà stor som om man odlat vete s:

Det krắvs $10 \mathrm{~kg}$ ráoplum för att framställa ett kg heroln

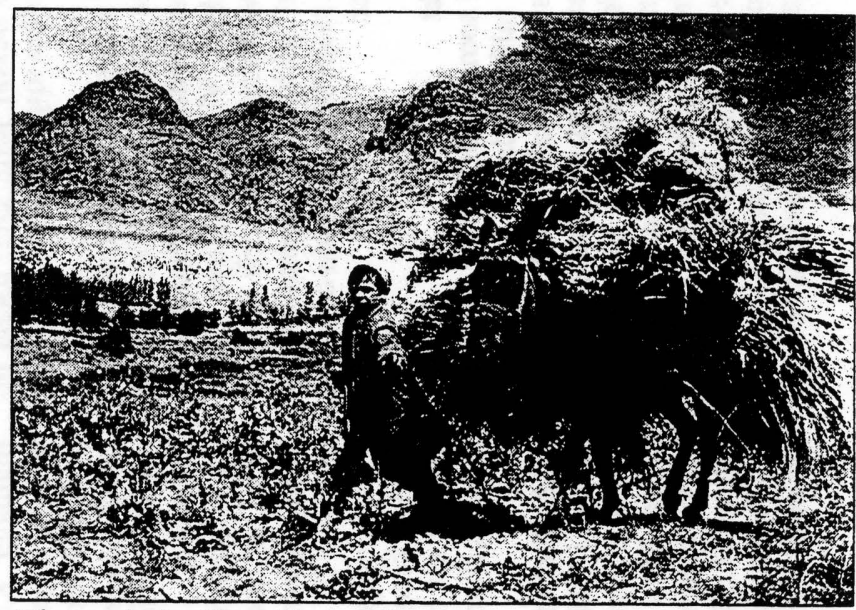

Mánga smápojkar tänker bll oplumodlare som pappa när de bllr vuxno.

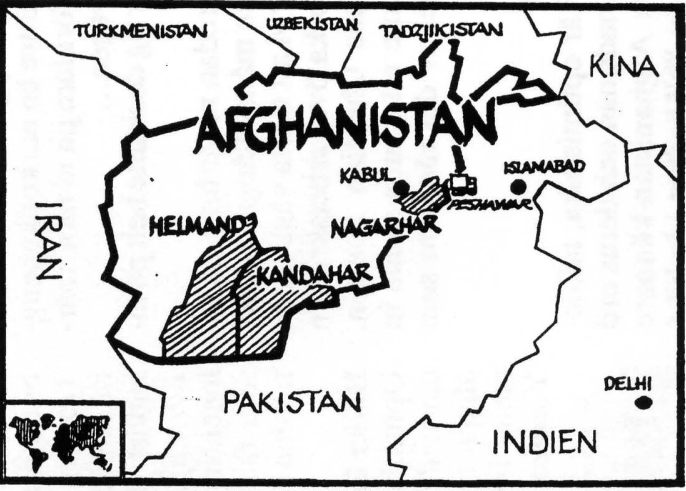

Tre provinser, Helmand, Kandahar och Nangar har stair for nära 80 pronara 80 pro umprodultio nen I Afghantstan. Men odlandet sprit der sig nu snabbt till an snabot till andra delar av

UNDCP:s nya projekt, som siktar till att få slut på opiumodlingarna inom tio år, har fătt en katastrofal start: Årets opiumskördar slår alla rekord med en ökning på hela 25 procent precis som i fjol. 2.800 ton, långt mer än i Burma och den Gyllene triangeln!

\section{Talibansk kontroll}

Och detta trots att 96 procent av allt råopium i landet produceras i områden som kontrolleras av talibanerna, de militanta heliga krigare som söker skapa det enda sanna islamska samhället baserat på sin egen bokstavliga tolkning av koranen och profetverserna skrivna för 1.400 \& sedan.

Talibanerna forrbjuder musik, teve och kosmetika, deras polis jagar böneskolkare och män som misstänks ha klippt sina skägg men bryr sig inte om opiumfälten trots att det är matbrist varje vinter.

En orsak är att de finansierar sina blodiga krig med skatt som de kräver opiumbönderna på.

Ushr, som det heter på pashtu, är ett slags tionde även om det ibland kan uppgå till 20 procent av intäkterna.

\section{Lovat förbud}

Visst håller talibanerna med om att narkotika är "haram", d v s synd. Flera gång er har de lovat att förbjuda all odling av vallmo men i slutändan har man varje gång hänvisat till den obeskrivliga fattigdomen $i$ landet.

- Vi kan inte ta levebrödet från bönderna, har man sagt.

Men samtidigt har man förbjudit odling och försäljning av cannabis trots att det är mindre skadligt än opium och he-

En orsak är att många afghaner missbrukar cannabis medan all opium och allt heroin smugglas ut, främst till Europa.

Många opiumbönder rättfärdigar hanteringen med att folk iden rika västvärlden är "infidels", icke troende.

- Talibanerna anser att de har rätt att "ge igen" mot omvärlden som giort Afghanistan så mycket ont och sedan smitit från sitt ansvar när väl afghanerna besegrat kommunismen, säger en brittisk biståndsarbetare.

Naturligtvis kan man förstå opiumbönderna: Vad betyder det om några dör av överdoser $i$ ett land långt borta när deras egna barn svälter?

Många ser opiumfältet som sin enda framtid.

- När man frăgar småpojkarna vad de vill bli när de är vuxna s̊̊ svarar de ofta

Odlas på bästa jorden

Opiumodlingen är helt olik den i Burma där man enbart utnyttjar den magra jorden på bergssluttningarna. De afghanska bönderna använder sin bästa jord och har expertis nog för att få ständigt ökad avkastning.

Det beror på att det saknas bevattning och ingen har råd med konstgödning.

Vallmon är den överlägset tåligaste och mest lättskötta grödan och man får betalt förskott av uppköparna som också själv kommer och hämtar varan.

UNDCP räknar med att det finn $20(0) .00()$ familjer som nu odlar opium pă 

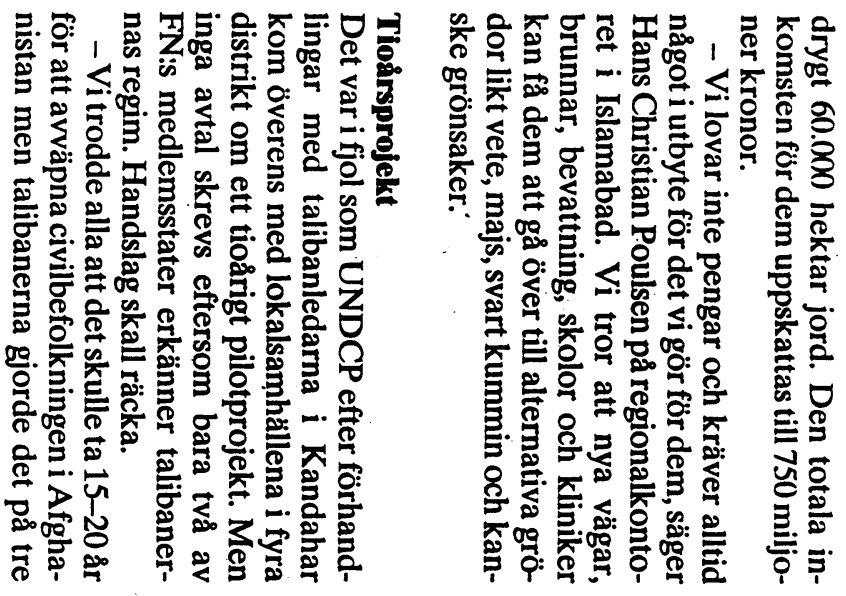

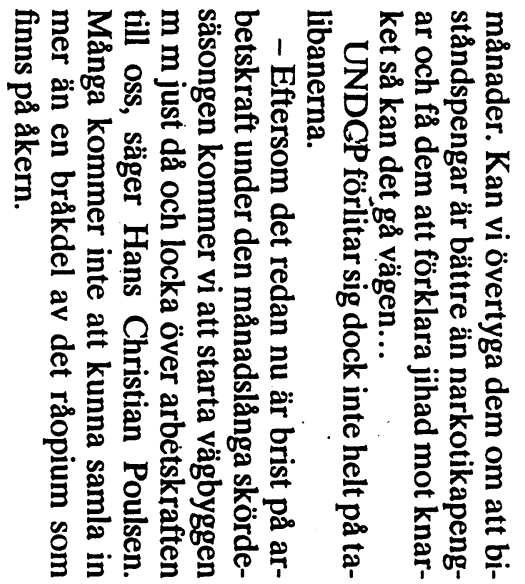

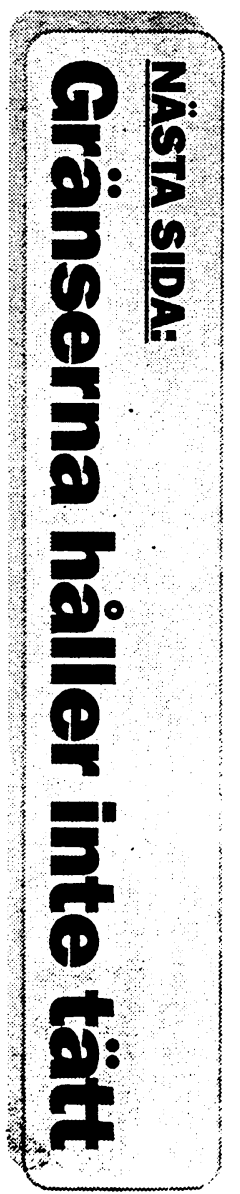
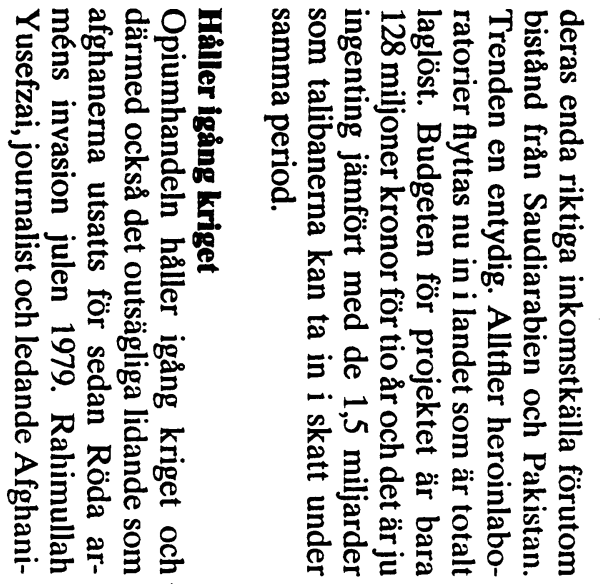

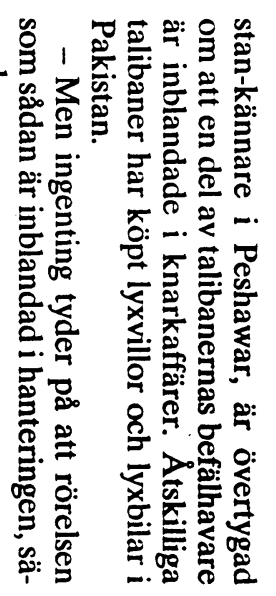

\section{Afghanerna behöver vår hjälp}

$\mathrm{J}$ Cordbävningen - hjälpen kom fram står det på omslaget till Afghanistan-Nytt (1998:I). Den 4 februari omkom 2300 människor i Rustaq i norra Afghanistans bergstrakter på gränsen till Tadzjikistan. En lycklig tillfällighet gjorde att Afghanistankommittén har skolor, kliniker och en fordonspark i närheten och kunde skynda till hjälp. Den svenska allmänheten har bidragit.

I slutet av maj drabbade en fem till sex gånger så stark jordbävning den nordvästra delen av Afghanistan, vid Kol Darrah. 5000 människor omkom, och mångdubbelt fler blev hemlösa. Afghanistankommittén, Röda korset, Läkare utan gränser och andra hjälporganisationer försöker rädda de överlevande. De dubbla skalven är Guds hämnd för att folket däruppe inte har accepterat vår regim, hör man talibaner säga, dessa religiösa fanatiker som ockuperar delar av Afghanistan.

Helikoptrar startar från Faizabad och Dushanbe i Tadzjikistan. De kostar 7000 dollar i timmen. Dåligt väder har gjort det omöjligt att nå mer än en bråkdel av de raserade byarna i oländig terräng. Afghanistan har ingen regering, ingen armé, ingen infrastruktur som kan hjälpa det egna folket. Det enda vi kan göra som lever på fast granitgrund $i$ ett land där inga politiska problem är på liv och död är att hjälpa med vår skärv.

"Söder och norr om Hindukushs stålblå massiv rustar talibaner och anti-talibaner för den sista striden. Under åkallan av Guds välsignelse förbereds tusentals nya unga män som kanonmat. Ar afghanerna tokiga? Tycker de om att slåss? Har det alltid varit så här? Om inte - hur började eländet?" skriver Peter Hjukström desperat i sin ledare i Afghanistan-Nytt. Och Tomas Löfström svarar i artikeln "Revolutionen som födde en tragedi".

A llting började med Saur-revolutionen 1978, då ett elitärt afghanskt kommunistparti genomförde en militärkupp. Ett ögonvittne till händelserna var professor Bo Utas, som intervjuas om revolutionsdagen i Kabul, då "allting vilade på en egg". Ett historiskt dokument! Tjugo månader senare rullade sovjetiska stridsvagnar in på Kabuls gator. Utas och Löfström visar hur politikers oöverlagda handlingar, folkets utanförskap och utländska stormakters inskridanden ledde fram till sovjetinvasionen den 27 decembèr 1978.

Sovjetinvasionen i sin tur inledde den våldsamma förstörelse av Afghanistan som Bo Utas betecknar som "fullkomligt fasansfull". Hans enda hopp är afghanernas seghet, förmåga att organisera sig och överleva nästan vad som helst. Sixten Heppling påminner i minnesord över en avliden premiärminister från 1960-talet, dr Muhammed Yusuf, om ro6o-talets tid av ljusa förhoppningar och modernisering i landet. Nancy Dupree berättar hur hon och hennes numera avlidne man Louis Dupree utvisades efter "den ärorika revolutionen"; hon överger dock aldrig Afghanistan.

\footnotetext{
kimrande bilder av smaragder från Panshjir, världens kvalitativt bästa, åtföljs av en text om de fruktansvärda arbetsförhållandena i smaragdgruvorna. En rapport om hur dricksvattnet kan förbättras i norra Afghanistan av Maria Tropp vittnar om att någonting positivt görs. Till sist åter en olycksrapport av Börje Almqvist, om svälten i Hazarajat efter att snön vräkt ned denna vinter. Alla barn är undernärda, och 35000 människors tillstånd betraktas som kritiskt. "Vi har inga pengar, och det finns heller ingen mat att köpa. Om det inte händer något snart, riskerar vi att svälta ihjäl", skriver en hazara till en släkting i Sverige.

Vi kan hjälpa afghanerna genom att inte överge dem, hur illa vi än tycker om talibanerna, genom att försöka förstå landets historia och de faktorer som har lett till denna förstörelse, och det gör vi genom att läsa Afghanistan-Nytt, som man automatiskt fằ för 185 kronor om året som medlem av Svenska Afghanistankommittén. Hjälpen kommer att behövas länge än; var säker på att den kommer fram!
} 
In av vărldens största producenter:

Irots att det är förbjudet att odla opium i Afghanistan finns odlingar helt synliga utmed de stora vägarna. Alla parter inblandade i kriget har ekonomiska intressen i opiumet, rapporterar SvD:s utsände Jan Blomgren.

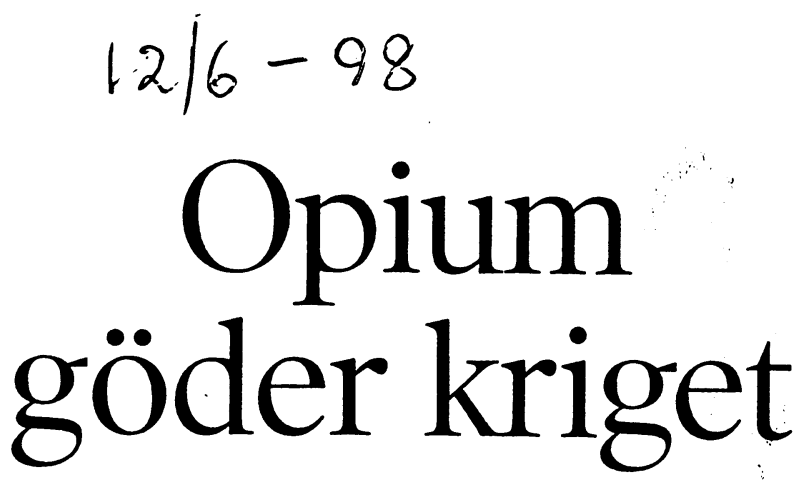

FAIZARAD, SVI)

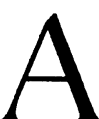
dul Rafure haller vallis knoppen i sin hand och blickar ut over det blommande faltet. De vita och mande faltet. De vita och
röda blommorna ser till att hảlla Abdul Rafures familj vid liv.

- Om jag odlar potatis eller säd kan jag kanske fă ut 100 dollar för det faltet. för en sådan här vallmoodling betalar maffian omkring 800 dollar, säger Abdul Rafure om ett fält pả 400, kanske 500 kvadratmeter.

Enligt Abdul Rafure kan fältet skōrdas pả vallmon sex till åtta gảnger per ár och varje gảng handlar det om cirka sju kilo. Det betyder att maffian som handlar av Abdul Rafure säkert tiänar tio gánger sá mycket och att fortjänsten tiogánger sả mycket och att forttiänsten

i nästa led, när knarket når ut

Samtidigt är det just opiumhantering som făr inbördeskriget i Afghanistan att blomstra och som ger freden en sá liten chans.

-För fredsprocessen är opiumbantcringen mycket negativ. Mảnga lokala befälhavare fảr sina inkomster tack vare odling och smuggling och det är kriget som ger dem så goda möjligheter till den verksamheten, säger Haseeb Sahibi denverksar
till SvD.

Han är ansvarig för Drug Control and Developitient Foundation (DCDF) som

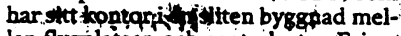
lan flygihtsen och centrilorten Faiza-

Vallmoodlingarna ar rorbfudna, men de blomstrande fälten som avlöser varandra även vid de centrala transportlederna - som i bland kan liknas vid vägar, men som är omöjliga för vanliga bilar och passar bäst för åsnor - visar att bönderna inte behöver vara särskilt ängsliga för att lagen ska forsöka nå dem.

Afghanistan har under de senaste áren etablerat sig som en av vârldens ledande opiumproducenter. Enligt en nyligen utgiven FN-rapport producerades 5000 ton opium under 1997 , varav hela 80 procent kom från två länder hela 80 procent kom frả

- Det finns tvă huvudanledningar till att Afghanistan blivit centrum for opiumhanteringen: kriget och den katastrofala ekonomiska situationen i landet. Det var under kriget med ryssarna som opiumodlingen tog fart och sedan har det bara fortsatt $i$ allt större omfattning. Därfor är det idag stora ekonomiska intressen som inte vill ha lag och ordning i landet, menar Haseeb Sahibi.

Knarkkungarna har under de senaste árens anarki växt sig allt starkare och skaffat egna armecr, flygplan och tanks. De har ocksá allt mer växt in i det politiska vardagslivet och uppges verka pả båda sidor $i$ inbördeskriget.
Gencralerna Abdul Shah Massoud och Abdul Rashid Dostam står i spetsen for oppositionen emot talibanerna som for tillfallet haller huvudstaden Kabul. Alla parter finansierar huvud sakligen sina krigsutgifter med opiumhandeln. Och varifrán skulle annars pengarna komma i Afghanistan, som máste vara ctt av världens fattigaste och mest outvecklade länder?

Det är den legendariske befälhavaren Massoud, "lejonet från Pamir", som leder offensiven mot talibanerna som inleddesi mitten av maj. Han ledde ócksả motståndet mot ryssarna pả 1980talet. "Närsnön smälteroch bladen börjar grönska är det dags att kriga", säger att det nu i allt högre grad är ett krig med talibanerna som forsvarare. den stora jordbävningskatastrof som drabbade norra Afghanistan i slutet av maj och som giorde en redan svår situation än värrefro

Den $\mathrm{r}$ juni stod ett viktigt slag om den strategiskt mycket viktiga bergshöjden Sha Ker dala, is kilometer norr om Kabul, där Massouds styrkor tvingade ningar. Det tycks som om talibanern är rejält försvagade jämfört med,för et ár sedan.

Den extremt islamistiska talibanterriber 1996. Massouds styrkor tämna de huvudstaden efter att ha forlorat flera stora drabbningar, men ocksả for att spara huvudstaden från total ödeläggpara huvudstaden från total ödelägning i de södra delarna av landet. De ning i de södra delarna av landet. De
kontrollerade ungefär tvá tredjedelar kontrollerade ungefär tvả tredjedela stöd och sáväl ekonomisk som militär hjälp frản i första hand Pakistan och Saudiarabien, men ocksả ả tminston indirekt frản USA.

Det amorikanslca intreaset handladehuvudsakligenomatt talibanerna hadegaranterat byggandet av pipelines för gas från grannstaten Turkmenistan gen exporten skulle ske i samarbete med amerikanska bolag. En chans som dag tycks minimal inom överskádlig framtid. Men än viktigare for talibanerna är att Pakistans intresse svalnat rades i samband med kärnvapensprängarna, prioritet.

- Talibanerna håller också på att tap- Talibanerna hảller också på att tapde att talibanerna skulle skapa lag och de att talibanerna skulle skapa lag och ordning, lite stabilitet i landet. Förväntningarna var hơga, men har inte på något sätt infriats, säger Siddig Barmak,
Krizet har pâ intetgltt páverkats av bort talibanerna frän sina försvarsstälrörelsen tog, över Kabul den 77 sepInte av politiska skäl, snarare kräver konflikten med Indien, som accentue fly Kabul när talibanerna tog över
Nu bidar han sin tid i grannrepubliken Tadzjikis' ins huvudstad Dusjanbe $i$ väntan pá en chans att få átervända hem och återuppta sitt arbete.

Siddig Barmak var under fyra ár ansvarig för det statliga filmbolaget, me i likhet med situationen for musiker skådespelare och andra konstnäre fanns absolut ingen framtid i Afghanistan under den nya regimen. Alla som haft chansen har flyttlandet. Siddig Barmak säger att han har sex regissörskollegersomarbetariMoskva, mángafinns också i Västeuropa och USA.

- Talibanernas lagar överensstäm- Talibanernas lagar överensstämmer inte ens med islamiska ideal, vilket snabbt skapade konflikt. Vi trodde på
en viss frihet pá högskolor och univeren viss frihet på hờgskolor och universur. Vi trodde ocksá pá en viss ekono misk forbättring, men situationen $\mathrm{i}$ dag

är värre än någonsin, säger Siddig Barmak och berättar att Kabul $i$ allt högre grad avfolkas och förlorar sitt blomstrande gatuliv.

Mhanga Indurtaler ooh forretag har tvingats slå igen och Siddig Barmak säger att också vanliga mataffärer tving ats stänga $\mathrm{i}$ brist pá produkter. Bristen på mat för invánarna blir allt mer besvärande. Av de tvá och en halv miljon invànarnaibörjan av 1990-talet áterst3 kanske hälften Ingen vo-talet âterstár skulle kunna ge besked under det kaos som råder?

Enligt flerakällor skullegeneral Massoud relativt snabbt kunna sätta in en soud relativt snabbt kunna sätta in en avgorande attack cmot Kabul. Taliba-
nerna-har blivit avskurna fràn sitt stöd i öst och börjar ockşă tappa väster om huvudstaden. Men Massoud uppges

vara tveksamom fördelarna med att inta Kabul. Dels vill han spara staden och civilbefolkningen, dels har Kabul bara ett symboliskt värde så länge Afghanistan är sả splittrat som idag. Sannolikt tår istället nästa stora slag kring den betydligt nordligare och mindre staden Kunduz, som talibanerna fortfarande häller. talibanerna har, átminstone så länge stöd av general Abdul Rashid Dostam och den avsatte presidenten Burhanuddin Rabbani och de behärskar i förnuddin Rabbani och de behärskar i första hand de norra delarna av landet. oppositionep och mánga menar att den 1973 . kung Zahir Shah (lever nu i. Rom) mijligen skulle kunna vara den som kap forena de heta afyhanska viljorna. Finú kontrar med att utsikterna för fred är minimala med tanke på de enorma inkomsterna frản opiumhandeln och att det inte finns nảgot handeln och att det inte finns

- Drömmen om fred har i alla fall jag inte gett upp, säger regissör Barma somunder ett långt samtal med SvD int kan lảta bli att ställa frảgor om svensk filmindustri och berätta om sin beundran för Ingmar Bergman.

-Jag helt enkelt älskar Bergman I hans filmer är det ofta så lugnt på ytan men en sådan enorm kamp inom och -llan människor. Och tänk när man tâser intervjuer med honom och ser hu han öppnar sina innersta tankar och även avslöjar sina svagheter, säger Siddig Barmak och drömmer om att ha si idol pá plats i ett fredligt Afghanistan.

-En man som forlorat allt, familj, hus och arbete och står där med den klassiska Shakespearefrågan: Att vara elle inte vara, att begá självmord eller försőka fortsätta leva. Det vore ett tema värdigt herr Bergman, säger Siddig Bar-

Men att skapa fred i Afghanistan tycks för närvarande vara en närmast omöjlig uppgift. Sả länge vallmofälten tillăts blomma fritt finns det inte någon ordmán för konstruktiva fredsförhandingar.

JAN BLOMGREN

\section{Raffineras till heroin}

Optum är den intorkade mjölksaften frán de omogna frukterna av opiumvallmo. Tidigare röktes raopium av missbrukarc, men idag det vanligaste preparatet bland arkomaner beroin som utvinns fran opium Opizom, som unings rrán opium. Opium odlas i ett bälte fràn Mellanostern till Bortre Indien. Opiumvallmo odlas också som oljeväxt. Fröna används ocksá som
krydda i bröd. svD

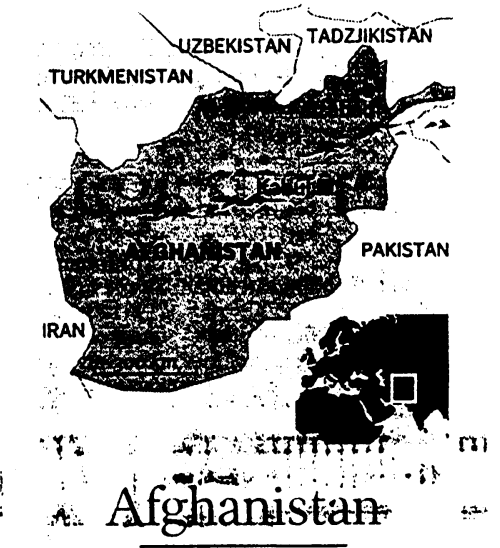

Euvidrtad: Kabul

Invinare:Mellan 150ch 18 miljoner (osäkra siffror på grund av krigsåren).

Bofollrning Io större och fler än 30 mindre folkgrupper. Några av de största är pashtunerna. tadzjiker, uzbeker, hazarer, turkmener.

Roliglon: Islam. Flest sunni-muslimer men det finns minst en miljon shiiter.

Fort historil.

1073: Kung Zahir Shah störtas av en släkting en palatskupp. 1978: Hafizullah Amin griper makten vid en blodig kupp med stöd från Moskva. December 1979:"Amin avsätts i en Sovjetstödd kupp. Babrak Karmal installeras. Pả juldagen marscherar sovjetiska styrkor in i Afghadagen marscherar sovjetiska styrkor in i Afghalimska gerillan 1986-86: Mer än 100 o0o sovjetiska soldater i Afghanistan misslyckas med att krossa mujaheddingerillans uppror. Gerillan beväpnas bland annat av USA. Moskva installerar Najibullah som ny ledare. Den 15 februar 1089: De sista sovjetiska soldaterna lämnar landet.Don16aprd1, 1992: Najibullah gerupp makten, mujaheddingerillan intar Kabul. Koalitionen bryter samman och gerillafraktionerna börjar kriga mot varandra. September 1994: Talibangerillan griper in i stridern breng mot varand soptomber 1906: Talibangerillan intar Kabul, avRabbanis regering fallit. SVD 


\section{Afghanistan}

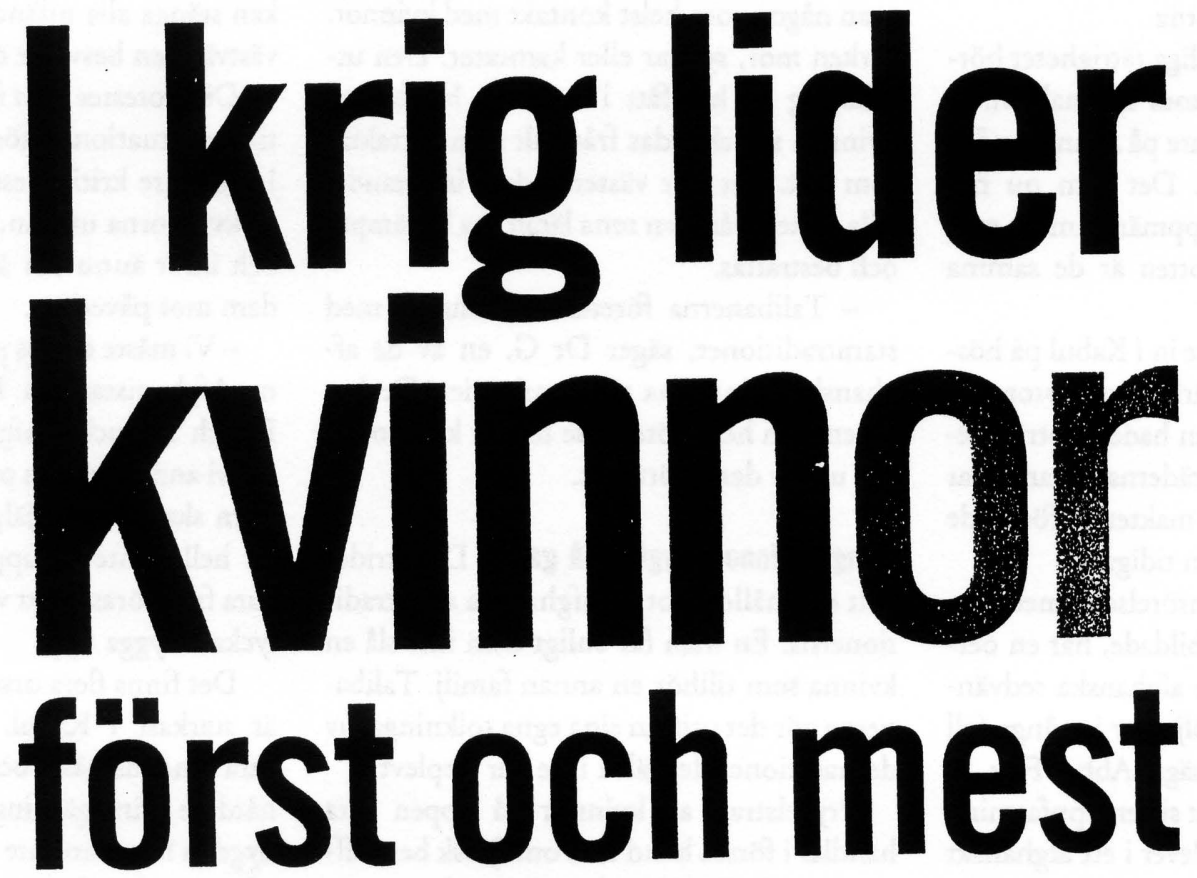

Ammiestiy press MI 3 Jun? 1908

- Vi har ingenting kvar längre, vi äger inte ens våra liv. Det är outhärdligt. För kvinnorna finns det ingen utväg.

Så beskrev en afghanska situationen för kvinnorna i Kabul, Afghanistans huvudstad. Det gjorde hon på ett seminarium som Amnesty International och LSE, London School of Economics and Political Sciences, arrangerade i London.

När talibanerna intog Kabul den 27 september 1996 dröjde det inte många timmar innan de första förbuden för kvinnorna kom. De fick inte längre gå i skolan, det gällde både småflickor och dem som studerade vid universiteten och de fick inte längre arbeta.

I ett enda slag utestängdes över 100000 flickor från vanlig skolgång. Över 8000 lärare, 70 procent av lärarkåren, var kvinnor som inte längre fick gå till sitt arbete. Det drabbar naturligtvis även undervisningen av pojkar. Det hävdas att upp till 150000 kvinnor utestängdes från sina arbeten.

En annan åtgärd som talibanerna vidtog var alt stänga de badinrättningar som fanns för kvinnor, en fick förbli öppen. Det skedde $\mathrm{i}$ en stad där det knappast finns vare sig vatten eller el. Ved är en bristvara även för det fátal som har råd att köpa den.

Förbuden har blivit fler sedan dess. Kvinnorna far inte längre gå ut om de inte åtföljs av en nära manlig släkting och de måste vara

Text: Rolf Herzman, foto: Martin Adler

klädda i chadari, dräkten som täcker dem helt och hållet. Ingen kroppsdel får synas.

- Det som vi hör från Afghanistan är vad som sker i Kabul, sa professor Fred Halliday från LSE. Situationen är allvarligare i huvudstaden men det förekommer stora brott mot mänskliga rättigheter i hela landet, bland alla fraktioner.

Sjukhusen för kvinnor stängdes, ett fick bli kvar. Organisationen MSF, Läkare utan gränser, har idag 35 läkare i hela landet."

- Drygt 70 procent av sängarna på sjukhusen är ämnade för män, sa Pierre Salignon från MSF. Ibland går det att förhandla med talibanerna så att vi i Kabul kan ha både män och kvinnor som arbetar tillsammans.

Talibanerna har kontroll över ungefär två tredjedelar av landet. I norr härskar krigsherrar som strider både mot varandra och mot talibanerna. De brott mot de mänskliga rättigheterna som begås där uppmärksammas inte lika mycket som de i Kabul.

I Afghanistan hade kvinnorna kommit längre i jämställdhet än i flera av grannländera. För snart 40 år sedan, 1959, togs tvånget att bära slöja bort. Kvinnorna fick rätt till utbildning och besatte med tiden höga poster inom samhället.

Under den sovjetiska ockupationen uppstod en motståndsrörelse, mujahedin. När
Sovjet lämnade landet 1989 tillsattes en kommunistisk skuggregering. I april 1992 tog mujahedin makten vid en statskupp och införde shariadomstolar samtidigt som man respekterade den största folkgruppens rådförsamling (pashtunernas jirga). Pashtunerna följer sina speciella levnadsregler, (pashtunwali) och visar stor trohet mot dem. Om det uppstår en konflikt mellan de egna levnadsreglerna och sunna, de islamiska levnadsreglerna, följer pashtunerna i första hand sina egna traditionella regler. Taliba-

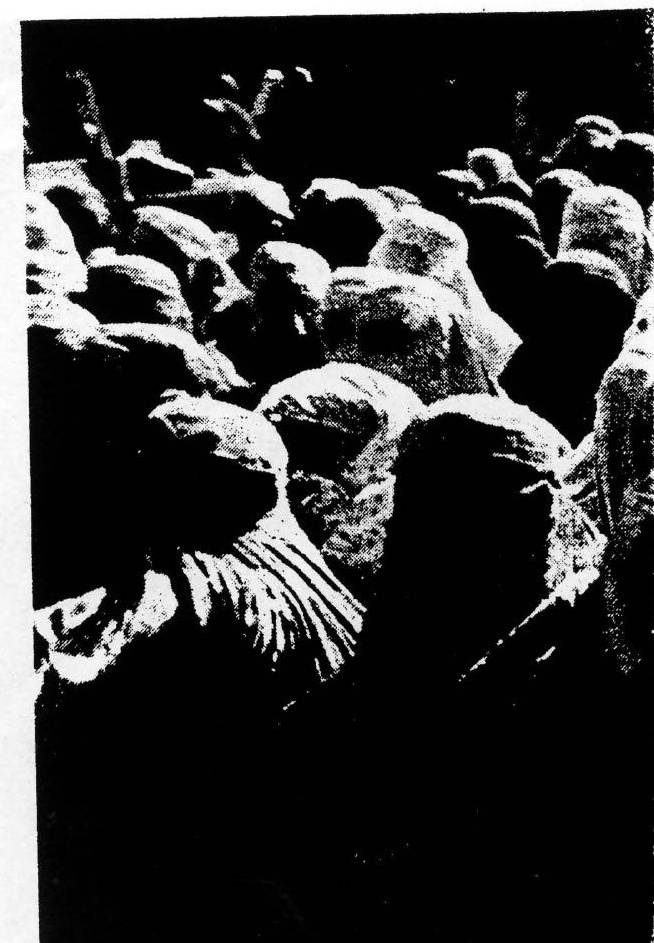


nerna däremot sätter sharialagarna först och främst. I den motsättningen finns en stark konflikt inbyggd.

Under mujahedin märktes en hårdnande attityd gentemot kvinnorna

- Brotten mot mänskliga rättigheter började innan talibanerna kom till makten, sa Abbas Faiz som är utredare på Amnestys Internationella sekretariat. Det som nu har skett är att vi riktar vår uppmärksamhet mot ett annat håll, men brotten är de samma som tidigare.

När talibanerna svepte in i Kabul på hösten 1996 vaknade västvärlden och protesterade. Men talibanrörelsen hade uppträtt redan 1994 och intagit städerna Khandahar och Herat. Där de tog makten införde de mycket strängare lagar än tidigare.

- De flesta av talibanrörelsens medlemmar är mycket dåligt utbildade, har en oerhört snäv världsbild. De afghanska sedvänjor som man säger sig följa har i många fall ingen tradionell grund, säger Abbas Faiz.

Talibanerna har bildat sig en uppfattning om hur de tror att man lever i ett afghanskt samhälle, de har sällan själva bott i det. De regler och traditioner man vill återinföra är vad man tror att de ska vara, inte vad de i verkligheten är.

Man bör skilja mellan begreppet taliban, som är en religiös student $i$ en hundraårig tradition med religionsskolor, och talibanrörelsen, som är en politisk och militär organisation med religiösa förtecken. Andra skaror, såväl rebeller som legosoldater, har också lockats till talibanrörelsen.

När Sovjet invaderade Afghanistan flydde över fem miljoner afghaner, tre miljoner till Pakistan och drygt två till Iran. De unga pojkarna sattes ofta i barnhem i flyktinglägren eller så skickades de till strängt religiösa skolor, maddras, i Pakistan. Talibanrörelsen hämtade sina medlemmar från dessa barnhem och skolor. Det gör att merparten av talibanrörelsens medlemmar har vuxit upp utan någon som helst kontakt med kvinnor, varken mor, systrar eller kamrater. Den utbildning de har fătt i skolorna hävdar att kvinnan ska skyddas från allt som betraktas som ont. Dit hör västerländskt inflytande. Alla avsreg från den rena läran ska bekämpas och bestraffas.

- Talibanerna förenar våldskultur med stamtraditioner, säger Dr G, en av de afghanska kvinnorna vid seminariet. De har ingen som helst förståelse för att kvinnor lider under deras förtryck.

Många kvinnor pryglas på gatan. Det strider helt och hallet mot de afghanska stamtraditionerna. En man făr enligt dem inte slà en kvinna som tillhör en annan familj. Talibanerna gör det utifrån sina egna tolkningar av de traditioner de själva inte har upplevt.

Prygelstraff av kvinnor på öppen gata handlar i första hand inte om fysisk bestraffning, de ska förödmjukas. De psykiska men kvinnan får är ofta djupare och långvarigare än de fysiska. Eftersom den sortens bestraffning är ett brott mot levnadsreglerna, pashtunwali, så förödmjukas hela familjen. Det blir ett sätt att förnedra och förtrycka.

Talibanerna har dock lovat att så snart som fred, lag och ordning är införda $i$ landet ska kvinnans ställning i samhället återupprättas och följa de islamiska lagarna.

Tre länder har erkänt Afghanistan under talibanerna: Pakistan, Saudiarabien och Förenade Arabemiraten. De stöttar såväl med pengar som med vapen. Och för talibanerna räcker det med tre länders erkännande. För alla som inte accepterar deras styre är emot dem, de är fiender.

Den talibanska regeringen har inte varit mottaglig för kritik från andra länder. När kritik har riktats har reaktionen varit att de kan stänga alla utländska hjälpstationer om västvärlden besvärar dem för mycket.

De protester som framförs i väst kan leda till att situationen för kvinnorna, förvärras. Ju starkare kritik desto större blir påverkan av kvinnorna utifrån, resonerar talibanerna, och inför ännu fler åtgärder för att skydda dem mot påverkan.

- Vi måste finnas på plats, vi får inte lämna Afghanistan, sa Elisabeth Winter från British Agencies Afghanistan Group. Hur ska vi annars kunna påverka och rapportera? Vem ska annars hjälpa kvinnorna? Men vi får heller inte ge upp i vår kritik, den ska bara framföras så att vi inte förstör det vi har lyckats bygga upp.

Det finns flera orsaker till att talibanerna är starkast i Kabul. Huvudstaden ansågs vara syndens näste och därför är talibanerna hårdare i sina gärningar där. Men på landsbygden har man inte samma grepp, där styr oftare stamtraditioner och patriarkaliska lagar.

Fred Halliday tror att talibanerna kommer att finnas kvar vid makten flera år till $\mathrm{i}$ sina två tredjedelar av landet. Stridigheterna kommer att fortsätta från alla håll. En oroande faktor är att etniska aspekter har dykt upp vilket kan få ytterligare allvarliga konsekvenser. Olika folkgrupper har ställts mot varandra inom landet, menar han.

En av de afghanska kvinnorna på podiet gråter när hon hör vad Fred Halliday säger.

- I ett krig lider alla, unga som gamla, säger hon. Men det är kvinnorna som får lida först och det är kvinnorna som lider mest.

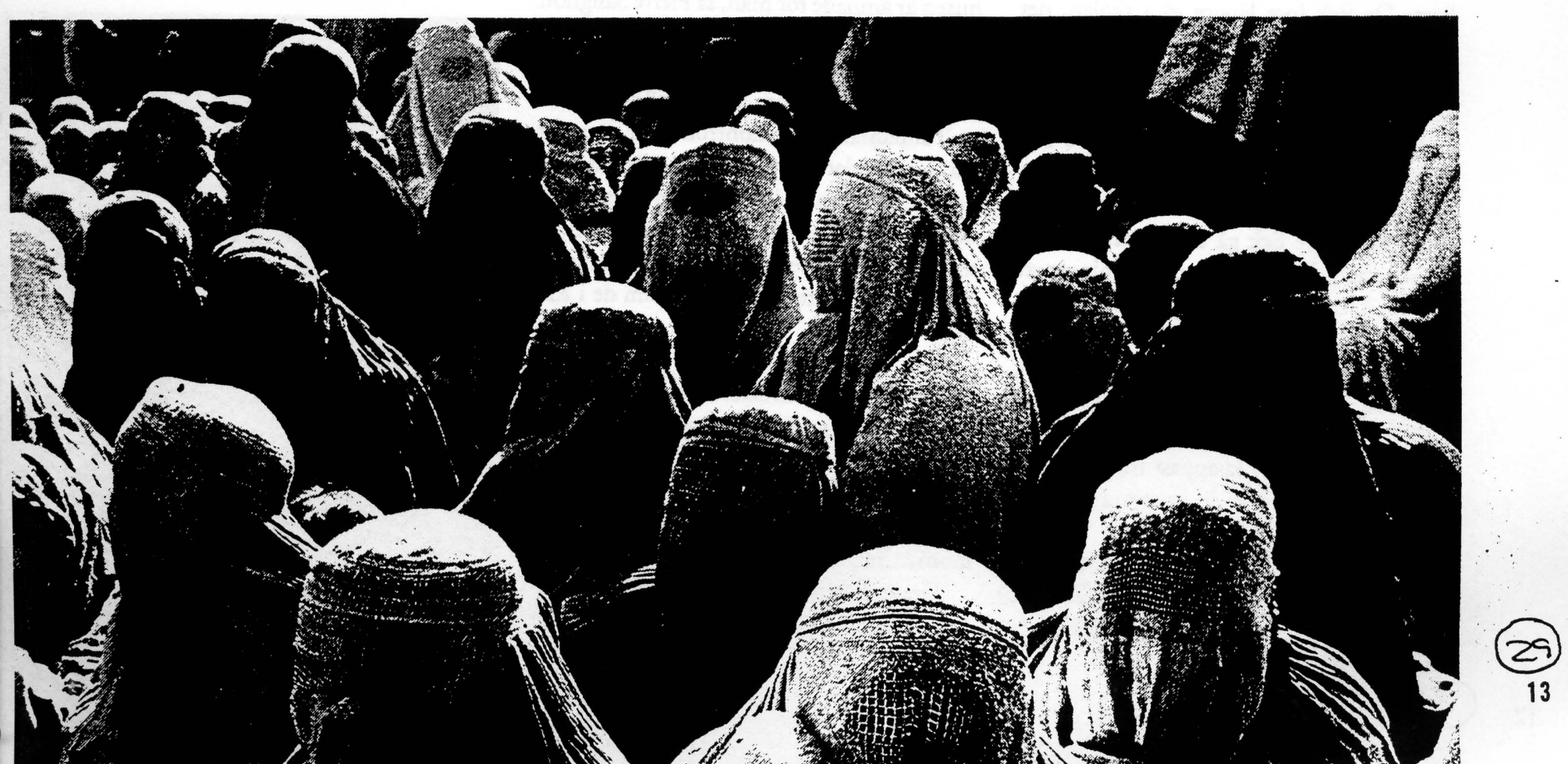




\section{Jag tänker ofta på Zobeida}

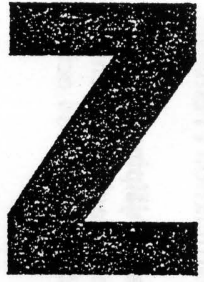
obeida var tretton àr gammal när jag träffade henne för sex àr sedan pà en skola för afghanska flyktingar i Peshawar i Pakistan. Det var avslutning för skoläret och barnen hämtade sina betyg, sjöng sanger och läste dikter. En ung, stolt och vacker flicka med slöja över det mörka länga häret. Hon småskrattade med sina vänner àt mitt besök och min kamera.

Via tolken fick jag Zobeida att berätta om sina framtidsplaner. Hon ville läsa vidare till läkare och hjälpa till att bygga upp landet efter det fruktansvärda krig som dà varat i femton àr, men som hon och alla andra nu hoppades skulle vara över. Hennes pappa hade just rest tillbaka till Kabul för att förberecia hela familjens hemresa.

Hon och alla de andra barnen gladde sig nu at att äntligen fà àtervända. Och de var mycket medvetna om sin egen roll. Deras kunskaper behövdes i hemlandet. Andra barn jag fràgade pả den här skolan gav liknande svar. De ville bli läkare, lärare, ingenjörer. Landet behövde dem, sa de.

\section{For:satt krigande}

När jag frägade eleverna pã en mindre skola på den afghanska landsbygden blev det andra svar. De skulle bli bönder och odla upp den jord som förstörts av kriget. Bevattningskanalerna var uttorkade. Vägar och broar sönderbombade. Och framför allt fanns det mängder av minor utspridda. De barnen var också medvetna om sin egen roll för landets framtid.

Att arbeta för sin familj och för sitt folk och land. Och de trodde dà, för sex àr sedan, att nu skulle det bli fred. Vägen mellan Peshawar och Jalalabad i Afghanistan var knappt farbar, men ändà körde där fantasifullt handmälade lastbilar överfyllda med afghaner pà väg tillbaka till hemlandet för att àterse sin hemby och åter bygga sitt hus och sitt liv $i$ fred.

Mảngas drömmar försvann med nya stridigheter mellan olika stridande grupper. Grannländer fortsatte att stödja "sina" vänner och uppmuntrade till fortsatt krigande. Hjälpen till fortsatt krig tycks mer profitabel än hjälpen till ett liv i fred.

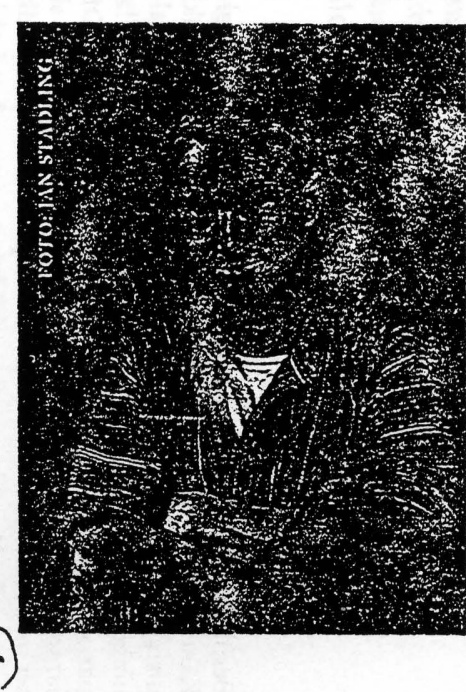

Jag tänker ofta på vad som hände med Zobeida. Hann hon resa tillbaka till Kabul? Och vad hände henne i så fall där? Kanske hon tillhör dem som återigen flytt? Nu kanske till en annan del av landet, som står utanför kriget? Kanske är hon idag läkare pả någon av de kliniker som drivs på den afghanska landsbygden via hjälp fràn Svenska Afghanistankommittén.

\section{Fler flickor än någonsin}

Flyktingarna fick mycket uppmärksamhet och hjälp under den tid landet var ockuperat av ryssarna. Därefter har hjälpen minimerats frän de flesta häll. Och när det står nàgot i media om Afghanistan sả är det bilder av talibanernas skräckvälde, om kvinnor som inte fär arbeta och flickor som inte fär gå i skolan. $P a ̊$ grundval av den bilden vill en del politiker nu att allt bistånd till landet ska upphöra.

Men bilden är inte helt sann. Som vanligt är verkligheten varken helt svart eller vit. För samtidigt som media säger att flickor inte făr gå i skola, så găr fler afghanska flickor än någonsin i skolor inne i Afghanistan idag.

Också i områden styrda av talibaner startas skolor för flickor. Svenska Afghanistankommittén ger idag bidrag till över 600 skolor med 160000 elever. Av dem är 32000 flickor. Och av de 5500 lärarna är drygt 600 kvinnor. Det är siffror som talar för sig själv. För fortsatt stöd.

Min egen fackklubb blev fadder àt Afghanistans barn och betalar en summa varje mänad. För oss är det ett litet bidrag. Men där ger det många barn en utbildning och en chans att känna glädje och stolthet över att ha en plats i uppbyggnaden av landet. Det är där den börjar; i utbildningen av barnen. Den glädjen har vi rảd att ge dem.
"Hjälpen

\section{till fort-}

satt krig

tycks mer

profitabel

än hjälpen

till ett liv i

fred" 

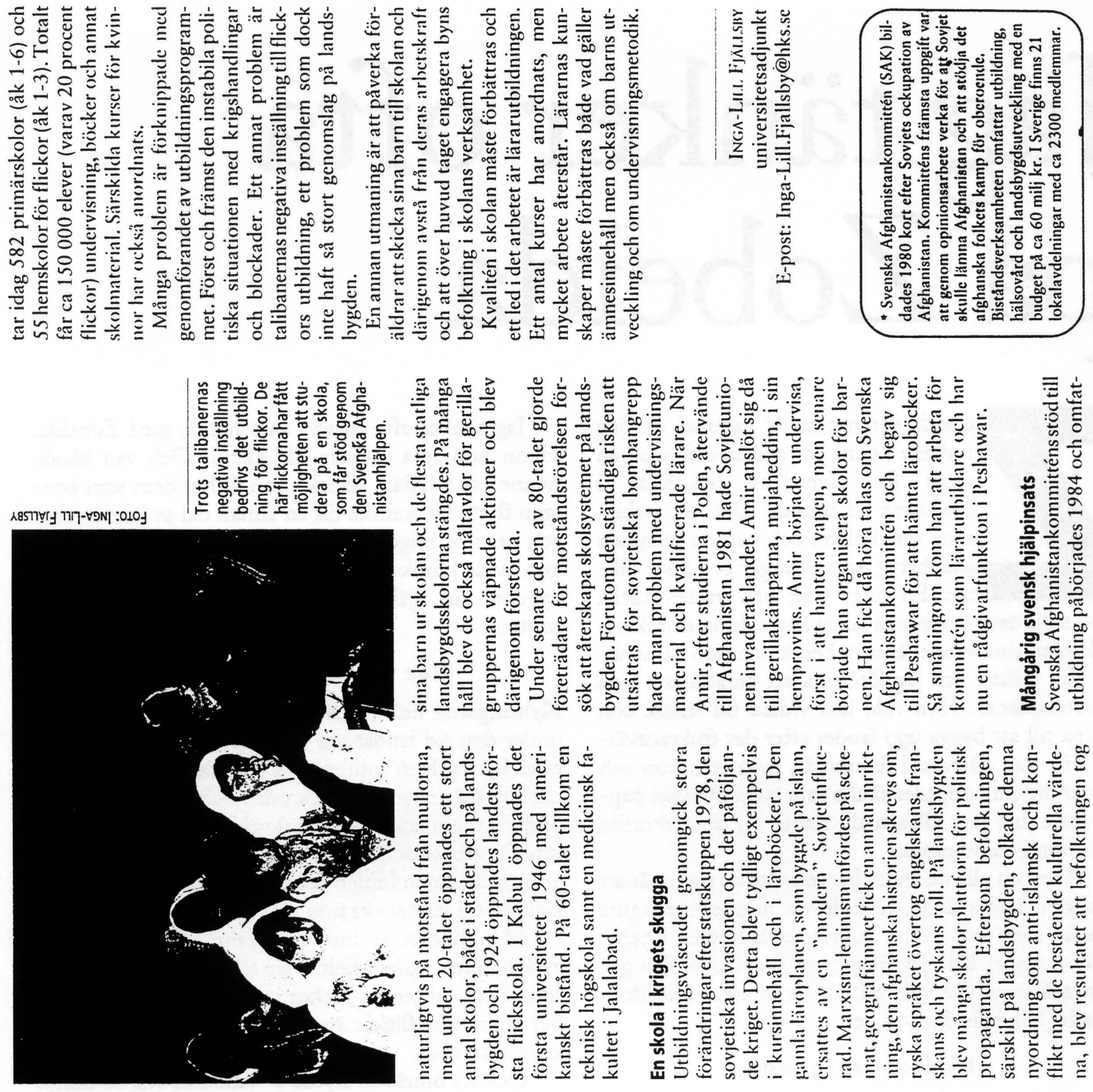


\section{Norsk press}

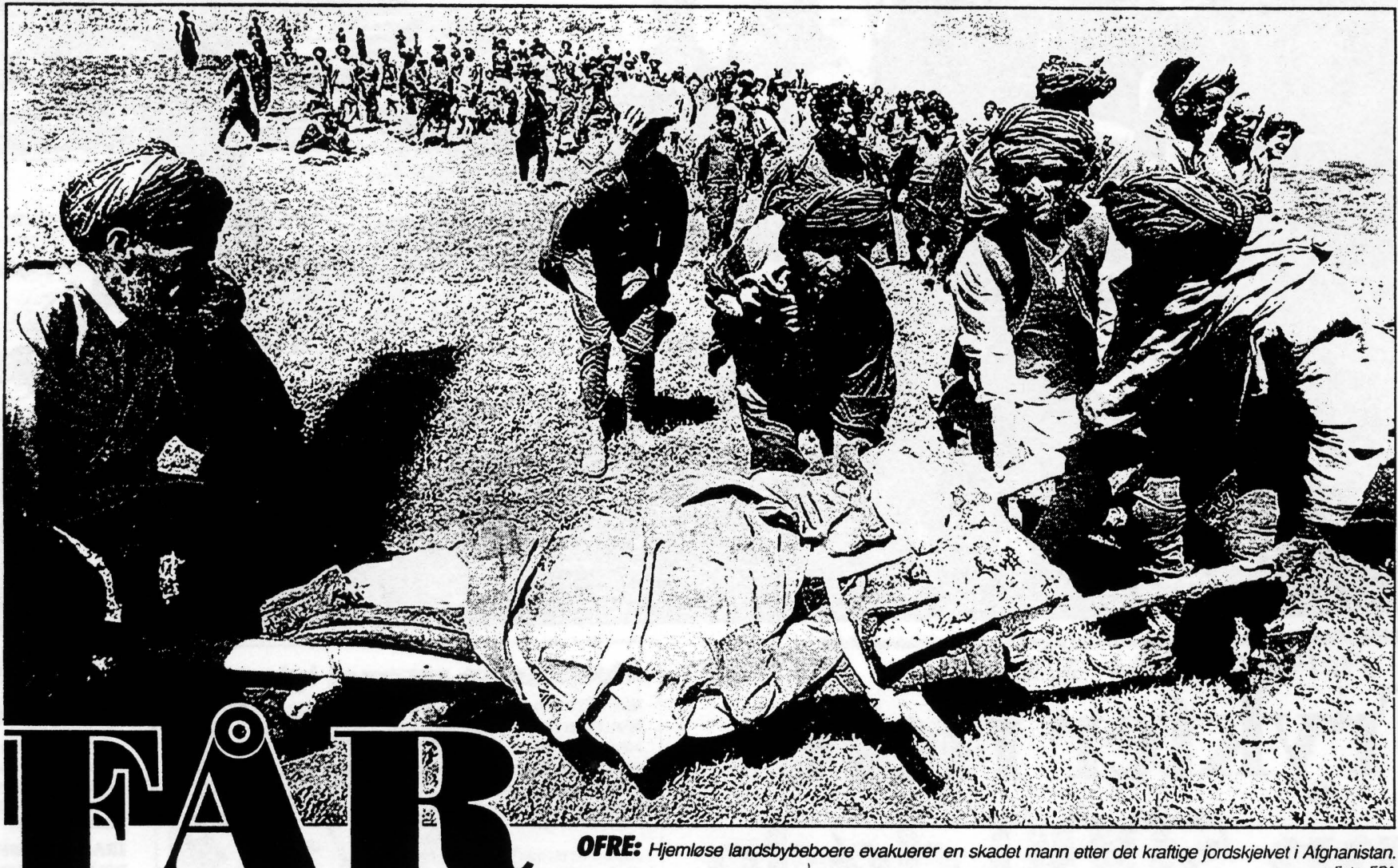

OFRE: Hjemløse landsbybeboere evakuerer en skadet mann etter det kraftige jordskjelvet $i$ Afghanistan.

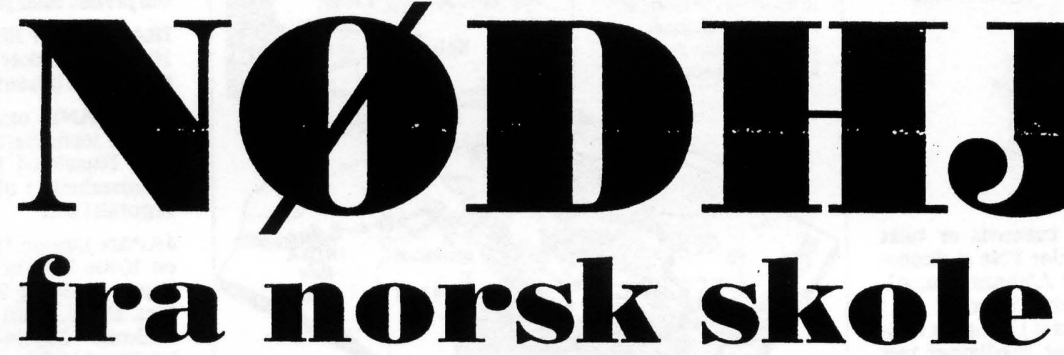

AV HARALD HENDEN Og LARS BARTH-HEYERDAHL

Denne skolen, som Afghanistankomiteen i Norge har bygd, skal være den eneste bygningen som fortsatt står i Shahr-e Buzorg i Nord-Afghanistan.

Herfra, midt blant ruineSa mange som 60000 til rammet av jordskjelvet, behovet for hjelp er akutt. Youngs førstehjelp blant $\begin{gathered}\text { Det er svært vanskelig à } \\ \text { frakte de sárede til sykehus. }\end{gathered}$ de rammede. Youngs er 50 ti timer til

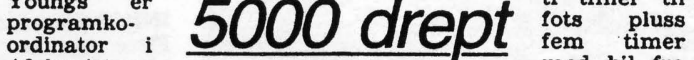
Afghanistankomiteen i i inrols/o/W/ Shahr-e-BuNorge. Hun I OTOSKON - zorg, opply. ankom til ser styrelelandsbyen
sondag kveld. sondag kveld. Kalasliole
Antallet Hornfelt i Afmiteen i Nor gár kveld anslảtt til rundt ge. Han har besøkt omrảdet 5000. Men hjelpemannskapen har enná lkke nádd alle lands byene som er rammet, og talnordøst i Afghanistan flere ganger.

- Shahr-e-Buzorg er et av Befolkningen lever fra hän til munn, og de militære utnytter nøden til à rekruttere nye soldater. Dette forsterker problemet, sier Hornfelt.

\section{Skolen står}

Senteret for lordagens jordskjelv ligger like vest for Shahr-e-Buzorg. Landsbyen var blant dem som ble hardest rammet av skjelvet. Skolen var den eneste byg ningen i omradet som fortsatt stod etter jordskjelvets massive ødeleggelser. Bygningen, som ble opprort 1 1994, er jordskjelvsikkert. De lokale husene er bygd av leire og kollapset under

- Youngs rapporterte om 80
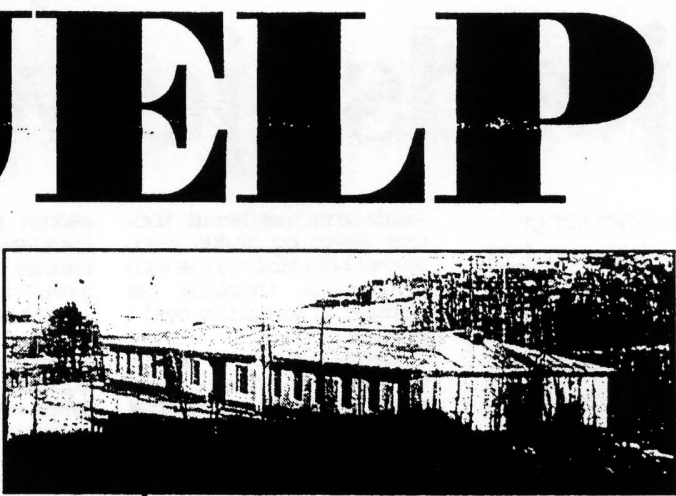

SKOLEN STAR: Helsesesteren Hermione Youngs har opprettet fors tehjelpssenter $i$ denne norskbygde skolen i den jordskjelvrammede delen av Afghanistan. Foto: AFGHANISTANKOMITEEN I NORGE

til 100 prosents odeleggelser av landsbyene hun fley over pá vei til stedet, fortelle Hornfelt.

\section{Forsyninger}

I gàr begynte forsyninger komme fram til de rammede omrädene i den nordøstlige delen av landet. Hjelpearbeidere gravde da fortsatt etter ofre i landsbyruinene. Et ukjent antall tusen mennesker har et skrikende behov for teit, mat og medisiner. Landets myndigheter appellerte 1 gär til verdenssamfunnet for
Foto: AFGHANISTANKOMITEEN I NORGE ger utilgjengelig til i fjellene. ranger

Tre fly fra Røde Kors hadde gar ankommet med forsyninger, og to helikoptre fraktet sảrede til sykehusene Rustaq og Badakshan. Därlig væ vanskeliggjorde arbeidet. I februar ble det samme omradet rammet av jordskjelv. Dette skjelvet krevde

Lordagens jordskjelv ble malt til 7,1 pá Richters skala og var dermed kraftigere enn det 1 februar. Helgas skjelv rammet ogsã dobbelt sả man-
ge mennesker. 


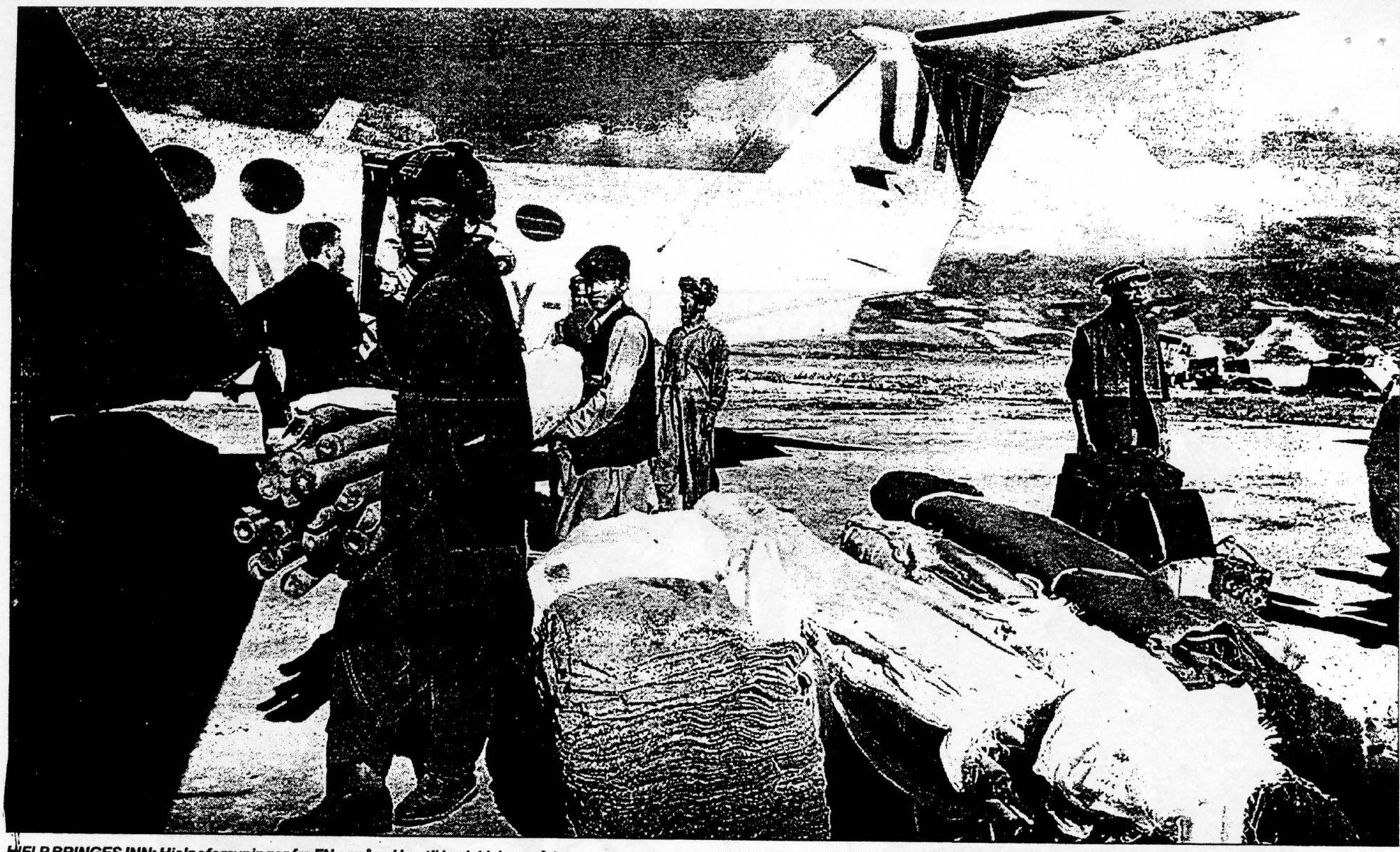

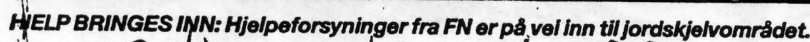
Aftenposten $2 / 6-98$

\section{Frykter flere enn 5000 døde i jordskjelvet}

sommantarac trilig omkommet i.25 a) 120 landsbyer som ble rammet av det knaftige jordskjelvet i Nord-Afgahnistan.

\section{THOMAS SPENCE}

Det gienstår 100-120 lands byer som ikke er registrert. Vi. frykter derfor at tallet på da mer, opplyser seksjonsleder i informasjonsavdelingen i Norges Røde Kors, UnniTeksum Kristoffersen. Generalsekretær Sven Mollekleiv i Norges Røde Kors flkk 1 går flere opplys ninger om situasjonen ulykkesområdet fra den ten Jarle Torgersen 1 Kabu Torgersen skal skal reise inn i området en av de nærmeste dagene.

- Til nå er det registrert døde og skadede i 25 landsbyer. sier Teksum Kristoffer

\section{Hjelp flys inn}

Været bedret seg noe 1 går ettermiddag, og giorde det mulig a bruke helikoptre til mennesker som trenger telt, mat og medisine

Tre Røde Kors-hellkoptre . området, og tok med seg skadede mennesker ut. Mel- sikkert at tusenvis er blitt lom 60000 og 70000 men- hjemiøse, sier FNs sjefkoornesker bor i landsbyene som dinator for Afghanistan, Al er rammet. Området ble fredo Writschi-Cestari. rammet av jordskjelv også 1

Mange har mistet famille og hjem, og trenger både husly, mat og medisinsk hjelp.

Skjelvet har gått verst ut over de tre områdene Shari-Bozurg, Badakshan og Takhar, i den nordlige fjellregionen, melder internasjo nen er befolket av bønder som har bygd sine leirhus i terrasser nedover fiellskráningene. Mange av disse landsbyene skal være helt utradert av jordras som

\section{Etterskjelv}

Shar-i-Bozurg skal være verst rammet. FN har fått meldinger om flere etterskjelv. Folk tør sannsynligvis kke være inne i hus som relativt dårlig vær og kaldt.

Ulike hjelpeorganisasjo ner anført av FN forsøkte går å nå frem med hjelp til de mange små landsbyene. Den franske hjelpeorganisasjonen ACTED opplyser at over 80 landsbyer er fullstendig rasert, 34 av disse Shar-i-Bozurg.

- Det er foreløpig vanskelig å kunne fastslå nøyakti hvor mange mennesker som
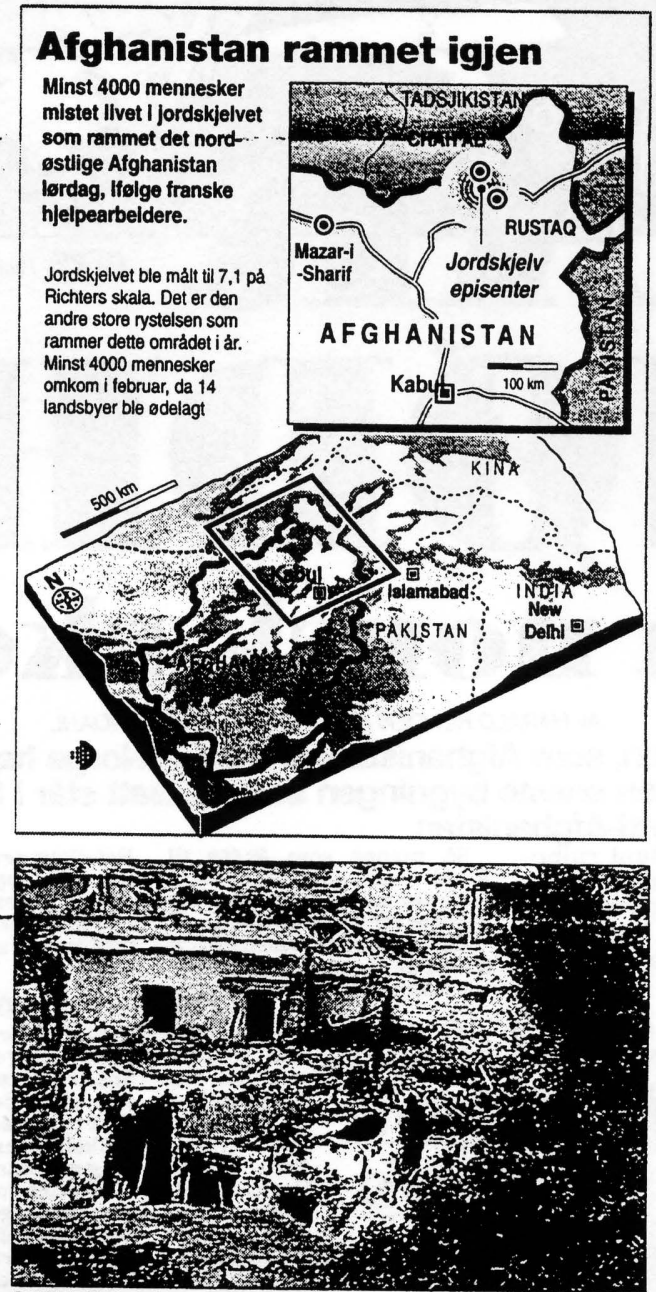

RASERT: Spinkle hus, delvis skadet under jordskjelvet ifebruar kunne ikke stå imot de kraftige rystelsene lerdag. FOTO: NTB/AP gionen i februar. Det kostet 4000 menneskeliv, i et områ de befolket av rundt 30000 Det siste jordskjelvet ha rammet dobbelt så mange mennesker over et stor område. Men til forskjell fra februar skjedde rystelsene denne gangen om dagen slik at mange flere var ute. februar kom jordskjelvet om natten mens folk lå og sov.
Jordskjelv de siste ti år AFGHANISTAN februar 1998: Minst 4000 døde i et jordskjelv i Rustaq-regionen vinsen Takhar.

IRAN mai 1997: 1560 mennesker omkom i de østlige ble jevnet med jorden.

IRAN Pebruar 1997: Omkring 1000 mennesker mistet livet nordvest $i$ landet.

RUSSLAND mai 1995: Det verste jordskjelvet noensinne i Russland krevde 1989 tegorsk i øst.

JAPAN januar 1995: Storbyen Kobe ble sentrum for et skjelv malt til 7,2 på Richomkom Skjelvet var det kraftigste i Japan siden andre verdenskrig.

COLOMBIA juni 1994: Om kring 1000 mennesker døde og 36 landsbyer ble ødelagt jordskjelv og jordras i Sørest-Colombia.

INDLA september 1993: 22000 mennesker mistet ble ødelagt i en rad kraftige rystelser i vestlige og sørlige

INDONESIA desember 1992: Flere øyer øst i Indonesia ble rammet av jordskjelv og lodborger. Minst 2200 menett av de verste som rammet Indonesia. omkom i et jordskjelv $30 \mathrm{mil}$ nordøst for New Delhi. PAKISTAN/AFGHANISTAN ebruar 1991: Omkring 1000 omkom i Afghanistan og 200 i Pakistan.

FILIPPINENE juli 1990 Minst 2000 omkom. Halv parten av dem som døde be fant seg 1 turistbyen Baguio. Nær 150000 ble hjemløse. IRAN juni 1990: 50000 om kom og 100000 ble skadet 1 den verste katastrofen noensinne 1 Iran. Rundt en halv million mennesker ble NTemigse NT/REUTERS 


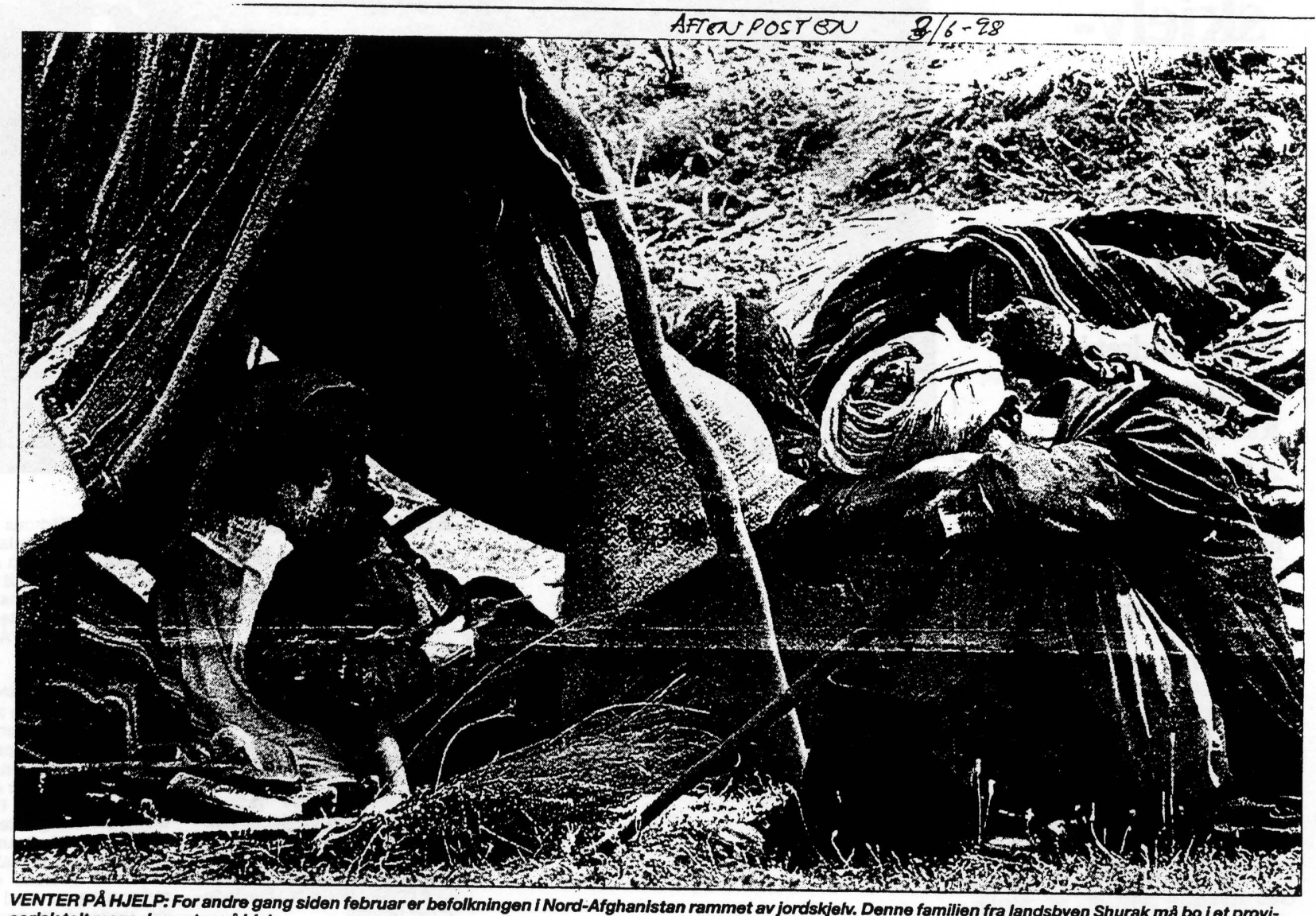

VENTER PÅ HJELP: For andre gang siden februar or befolkningen i Nord-Afghanistan rammet av jordskjelv. Denne familien fra landsbyen Shurak m\& bo i et provi-

\section{Krigshandlinger i jordskjelvområdet}

Det kan gå flere dager før redningsmannskapene når frem til alle ofrene for jordskjelvet i Afghanistan. Samtidig fortsetter krigshandlingene.

\section{THOMAS SPENCE}

I går ettermiddag hadde redningsmannskapene fortsatt bare nádd frem till og registrert skadene i 25 av de rundt 120 landsbyene i Nord-Afghanistan som ble rammet av det kraftige jordskjelvet lørdag.

- Først de nærmeste dagene vil vi ha en oversikt over skadene, opplyser informasjonskonsulent Marianne Wellén i Norges Røde Kors.

Hun var i går 1 kontakt med blant andre den norske Røde Kors-delegaten Jarle Torgersen 1 Kabul. Norges dagene avgjøre om organi- sasjonen skal sende fly med mannskap og utstyr til om rádet.

Jordskjelvet 1 helgen kan ha rammet et mye større område enn hjelpemannskapene har vært klar over. Tallet på mennesker som bekreftes omkommet er nesten 5000. Men fra helikoptre har, redningsmann skaper oppdaget at skjelvet har giort store ødeleggelser langt utover områder der hjelpen er blitt satt inn til nå,

olge NTB-Reuters-

- Det kommer meldinger om omfattende ødelegge ser lenger nord 1 distrikten Chah-ab og Shar-i-Bozurg. opplyste

Arsaken til at det tar lang id \& $n$ s frem de ødelagt skyldes dels vanskelige værforhold som rene sto på bakken de første døgnene, og dels at det dreier seg om svgrt avsideslig rende områder uten veje g infrastruktur.

Lidelsene til den fattige hardt prøvede befolkningen som sist var rammet av jordskjelv 1 februar 1 år, sy nes ikke å ha noen grenser. nemlig gjort det klart at de kke vil slutte å slåss, tros naturkatastrofen og redningsarbeidet som pågår : regionen.

Kampene pågår delvis 1 de jordskjelvrammede om radene, blant annet ved Bangi i Takhar-provinsen Nord-fraksjonen unde kommando av Abdel Ra shid Dostum gike it helgen til angrep på Tlulinan-milts sen i ly av katastrofen sen ly av katastrofen. Talian ble drevet tilbake pa stan.

\section{- Vi må forsvare oss}

- Vi har ingen planer om a sende hjelpeforsyninger Først må vi forsvare oss, sa Talibans informasjonsminister Mulla Amir Khan Muttaqi i går.

Talban, som kontrollere to tredjedeler av Afghanistan, innstilte kamphand- lingene midlertidig da et jordskjelv rammet den nordlige delen av landet $i$ brua

- Det blir ingen våpenhvie denne gang, sa Muttaqi. FN, Røde Kors og andre organisasjoner har sendt telt, mat og medisiner til den avsidesliggende jordskjelv-regionen. Det bodde 60000 mennesker i området som er rammet.

\section{Kolera-fare}

Det er mangel på mat, fordi matvarelagre er blitt begravd i sammenraste bygninger. Det er også fare for kolera- og dysenteriepidemier, og hjelpemannskapene frykter at de skiftende værforholdene kan forårsamalaria

Ifølge Marianne Wellén fløy tre helikoptre i går inn tepper, medisiner, leger, sykepleiere, logistikere o kommunikasjonsutstyr. Hardt sarede mennesker blir floyet ut igjen.

Fra Peshawar og Kabul deltar tre fly 1 redningsope rasjonen. Den norske Af ghanistankomiteens program-koordinator i Badakshan, Hermione Youngs, bekrefter at det er stort behov for mat, rent vann, ullteppe og telt.

\section{Ødeleggelser}

Hun opplyser på radio fra Shar-i-Bozurg at distriktet bare er tilgjengelig med helikopter og at det er ni ti mers gange til nærmeste bilvei. Biltransporten til nærmeste sykehus, i Taloqan 1 Takhar-provinsen, tar 16 timer

De materielle ødeleggelDene etter jordskjelvet e ent store er skadet, dør 1 landsbyen sine, forteller Youngs. En skole som Afghanistankomitéen bygde for fire år siden, er en av de få byg ningene som har klart jordskjelvet.

De ødelagte landsbyene ligger 1 over 2000 meters høyde og temperaturen varierer fra 20 grader om dagen til null om natten. 
AFTENPOSTEA

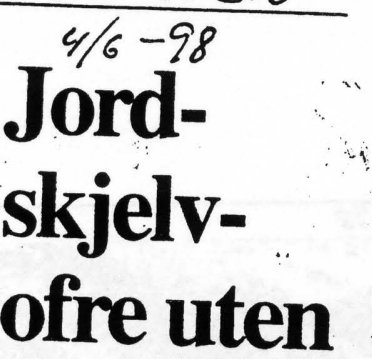

mat i

flere dager

Regn hindret $\mathrm{i}$ går hjelpearbeidet etter jordskjelvet $\mathrm{i}$ Afghanistan.

Faizabad

Flere tusen mennesker har ikke fătt mat på dagevis j det jordskjelvrammede området nord i Afghanistan: Flyplassen som blir brukt som hovedbase for redningsarbeidet i Faizabad, var oversvømmet av vann, og alle FNs hjelpefly mâtte innstilles.

- Vi må bare be om at vær ret blir bedre. Hvis dette regnværet fortsetter sá vili det utvikle seg til et mareritt, sier FN-talskvinne Sarah Russell.

FN- og Røde Kors-tjenesstemenn hadde håpet å trappe opp flywningene til de mest avsidesliggende omrs dene. I stedet ble de tvunget til å trappe ned arbeidet.

Hvor mange som omkomj skjelvet er usikkert, men hă:pet om å finne overlevende svinner for hver dag. FNEs opplysninger går ut på at 2500 er døde, mens hjelpo arbeidere har operert med tall mellom 4000 og 5000 ifis Flere steder skal det fojt satt pågá kamper mellog Taliban-militsen og den not dafghanske alliansen. Taif:ban nektet tidligere denne uken å gå med på våpenhvile, tross katarstrofen som har rammet befolkningen $-\bar{i}$ området.

NTB-AFP

\section{Kamper i Afghanistan}

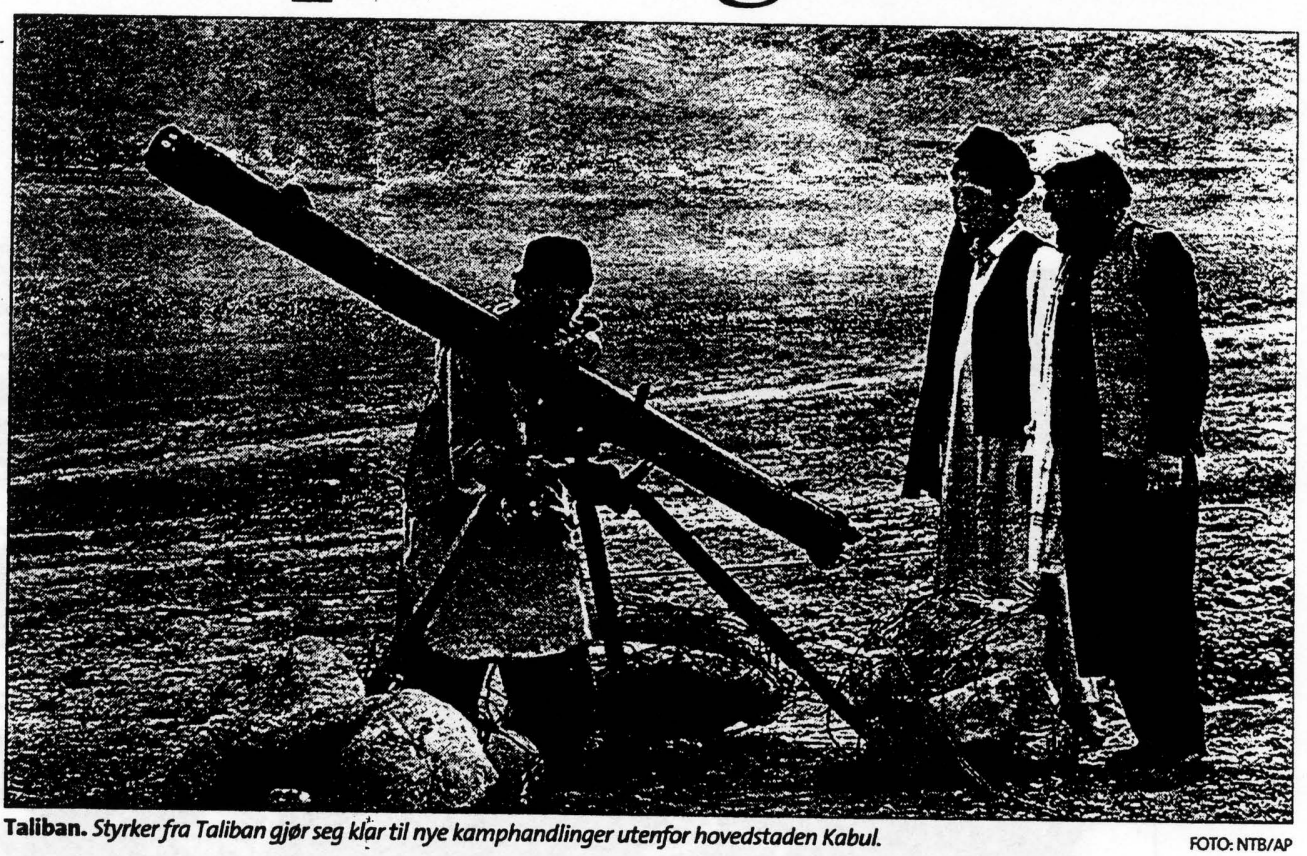

Krigen i Afghanistan går videre. Kampene braker løs igjen etter feilslått fors $\varnothing \mathrm{k}$ på fredsforhandlinger.

\section{GUNNAR FILSETH}

Rivaliserende afghanske styrker er igjen i kamp etter at fredsforhandlinger mellom det ultraortodokse Talibandet ultraortodokse Talibansen brøt sammen, meldes det fra Kabul. Bruddet kan gi st $\varnothing-$ tet til en ny Taliban-offensiv for $̊$ erobre den siste fjerdedefor á erobre av landet.

Under samtalene har hver
Un av partene åpenbart ladet av partene åpenbart ladet
opp til den årlige våroffensiven, som nå kan stå for døren. ven, som nå kan stå for døren. Store forsterkninger er sendt
til frontlinjene, i første rekke til frontlinjene, i første rekke til slagmarkene like utenfor den afghanske hovedstaden.
Partene beskylder hverandre nå for dårlig fredsvilje. En Taliban-representant har erklært at bruddet taler for en «militær løsning» på konflikten. Opposisjonsledere sier at selv under den avtalte våpenhvilen fortsatte kampene flere steder mens det ble snakket om fred.

\section{Blokade og sult}

Forhandlingene i Pakistan hovedstad Islamabad kjørte seg fast sist helg etter at Taliban hadde nektet å heve forsyningsblokaden av Hazarajat-regionen midt $i$ landet. Området kontrolleres av op posisjonen og er kringsatt av aliban-styrker.

FNs matvareprogram melder om overhengende fare for hungersnød blant titusener Hazarajat etter at avlingene i
for slo feil. Taliban nekter \& for slo feil. Taliban nekter a slippe frem hjelpesendinge
med den begrunnelse at ma ten ville komme fiendtlige styrker til gode.

Skoler blir stengt

Fra den sørlige Kandaharregionen meldes at Talibanregimet har stengt kontoret til en av Kirkens Nødhjelps samarbeidsorganisasjoner i Afghanistan. Som en følge av dette kan et 50-tall skoler som støttes av Kirkens Nødhjelp, representant Jan Åhlander ti Aftenposten.

\section{"Vestlig inspirert"}

Talibanledelsen skal ha kritisert at undervisningen har vært «vestlig inspingen har har trolig inspirert. Det at non sammenheng med at noen a enter, og at de har ansat ban lrunelige lærere. Tallban krever blant annet at de res egne lærere skal få under ise ved skolene og at lærerlønningene skal utbetales via undervisningsministeriet. Disse kravene godtas lkke av samarbeidsorganisasjonen ti Kirkens Nødhjelp, som spesielt arbeider for utvikling av ordbruket.

- Vår beste støtte er at lokalbefolkningen ber om at driften kommer i gang igien, sier Åhlander.

\section{Konflikt med FN}

Talibans langvarige disputt med hjelpeorganisasjonene om kvinners rettigheter er blitt tilspisset $\mathrm{i}$ løpet av våren. For to måneder siden stanset FN-organisasjonene hjelpearbeidet og trakk alle sine medarbeidere ut av Kandahar etter lor ter ler natt bistandsarbeidere var blitt mishandlet og trakas

Under forhandlinger som kom i gang mandag, krever en N-delegasjon at Taliban tar kvinnespørsmålet opp til ny vurdering, og at bistandsarbeidere blir behandlet med espekt.

Taliban håndhever strenge religiøse lover i de tre fjerdedeler av landet under deres kontroll. Kvinnene får ikke forlate hjemmet med mindre de er fullstendig innhyllet $i$ slørdrakten og ledsages av mannlige medlemmer av familien. Siste uke ble en kvinne straffet med 100 piskeslag på torvet i Kabul. Hun var blitt grepet i hor sammen min fetter. 

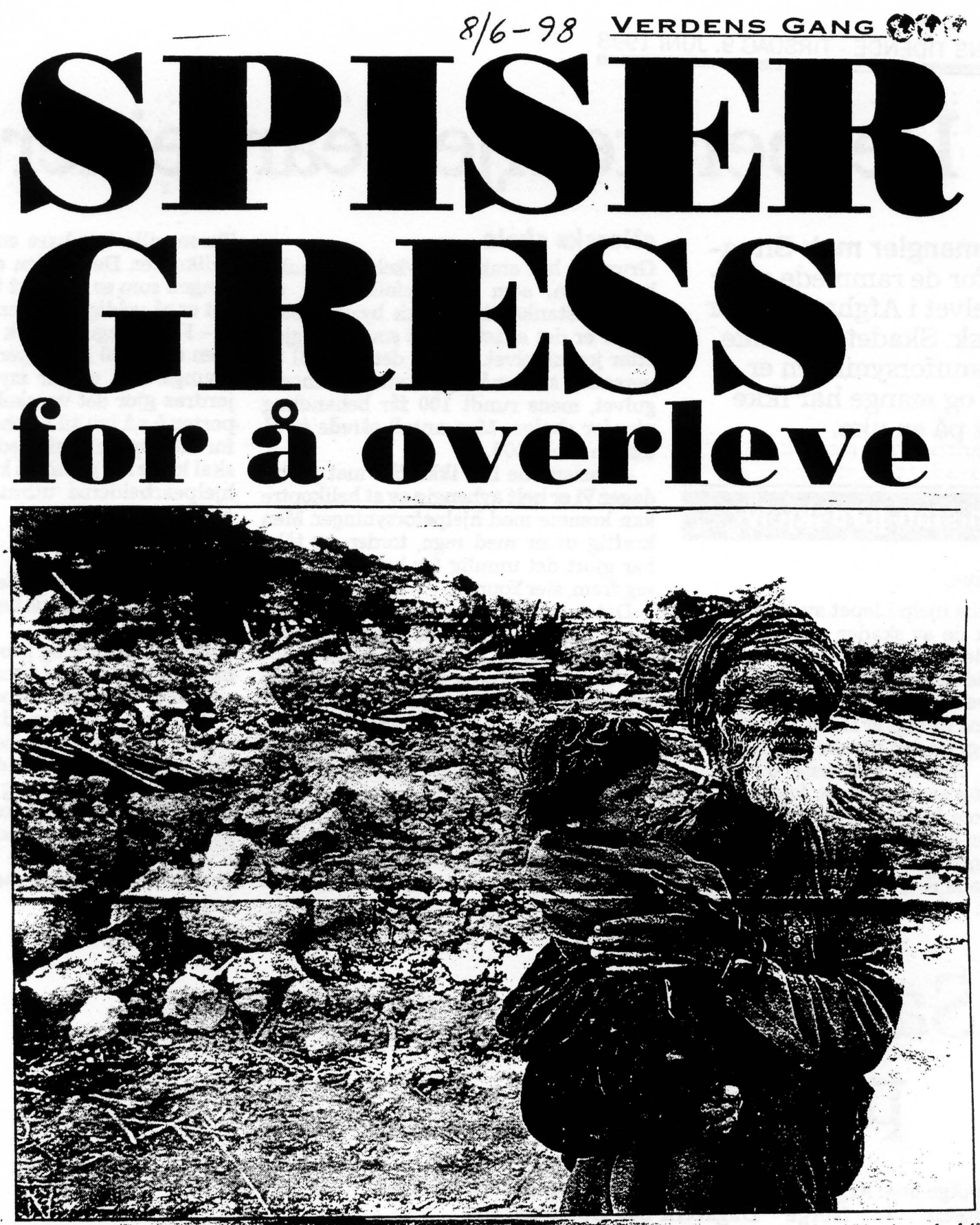

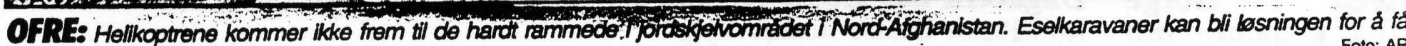
maten frem til de sultende.

AV HARALO HENDEN

Jordskjelv-ofrene i Nord-Afghanistan spiser nå gress og rotter for å overleve. Samtidig ligger forsyningene klare på flyplassen i Faisabad.

Mangel pả helikoptre gjør at mye av matvarehjelpen ikke kommer frem til de.veiløse landsbyene.

Eselkaravaner kan bli redningen for tusenvis av mennesker $\mathrm{i}$ dagene som kommer. - Sondag lastet vil 10 tonn hvete pá 200 esler og sendte karavanen ut pá den 24 timer. lange turen til Shahr-e-Buzorg, Som programkoordinator for Afghanistankomiteen i Norge har hun den siste uken ledet ihjelpearbeidet fra en norskbygd skole 1 landsbyen. Det er den eneste bygningen som stär igjen etter det kraftige jordskjelvet.

\section{At edelagt}

Youngs var den iorate hjelpearbeideren som kom til dette omrádet sandag for en uke siden.

uke siden. er delagt. Spesielt alvorlig er matvare-situasjonen. Etter en lang vin. ter er folks lagre tomt. Arets avlinger ble ødelagt før man flkk høstet dem. Vi vil se et alvorlig sultproblem 1 ukene som kom mer, sier Youngs.

Selv ga hun sine egne rasjoner, til syke huset som.ble etablert I den-norskbygde slrolen 1-Shape Bgyorg ory sitausj oñen ekstremt vanskelig ogsả for oss hjelpe- Buzorg. Samtidig ligger det matvarearbeidere, sier hun med grảt i stemmen. For lokalbefolkningen ser neste vinter dyster ut all

\section{Press på FN}

Av 52 landsbyer 1 omrádet ble 20 helt rasert. Ytterligere 20 er mellom 50 og 90 prosent ødelagt. BeSist lørdag var det to nye alvorligere rystelser.

Afghanistan-lomiteen I Norge vil ni ta kontakt med norsk UD for á øve press pá FN, slik at jordskjelvicotrene far mat.

Vare medarbeidere i Afghanistan er svært frustrerte. Ting kan

tyde pà at FN ikke pri-

oriterer bruken av de

livsviktige helikoptre-

ne godt nok, sier for-

komiteen,

Per Hornfelt til VG.

Han reagerer kraftig

pá at helikoptre har

landet nærmest tomme i det jordskjelvrammeblir flydd ut.

Telt og matvarer skal ogsa ha blitt lig journalister inn i omrádet. gende igjen mens hellikoptre har flydd 


\section{Desperate hjelpearbeidere}

Of́rene mangler mat: Situasjonen for de rammede etter jordskjelvet i. Afghanistan er nå kritisk. Skadete fắr ikke hjelp, vannforsyningen er ødelagt og mange har ikke fått mat på en uke.

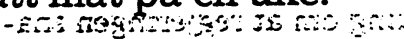

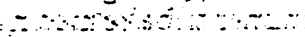

\section{afghanistan-jordskjelv}

MANBRITT DAHL

- Far vi-ikke hjelp.i Iøpet.av en dag eller to, vil folk dø av skader og sult, sier en trott og desperat Hermione Youngs til Bergenstidende på-telefon fra den veilose landsbyen Shar-i-Bozurg.

Hermione Youngs er leder for hjelpearbeidet i regi av den norske Afghanistankomiteen. Det er regionale og lokale myndigheter som har bedt Afghanistankomiteen om å koordinere arbeidet fordi de kjenner forholdene $\mathbf{i}$ området godt. Youngs samarbeider med FN, Leger uten grenser, Røde Kors og andre hjelpeorganisasjoner.
«Norsk» skole

Gruppen har etablert «sykehus» i skolebygningen, som lokalbefolkningen og Afghanistankomiteen fikk bygd i 1994 . Dette er det eneste huset som står igjen etter jordskjelvet. Her er det plass til 50 personer, som må ligge rett på sementgulvet, mens rundt 100 får behandling utenfor skolen. Men antall-sårede èr så mange som 1300 .

- Pasientene har ikke fått mat på tre dager.Vi er helt avhengig av at helikoptre kan komme med hjelpeforsyninger. Men kraftig uvær med regn, torden og tåke har gjort det umulig for helikoptre å ta seg frem, sier Youngs.

Det er stort sett kvinner, barn og eldre menn som er døde eller skadet. De var inne i leirhusene, som lå i terrasser nedover de bratte åsene. Đe unge mennene jobbet ute, og klarte seg relativt bra:

Natt til i fredag snødde det i fjellene. Landsbyen derYoungs holder til ligger på 2000 meter, og folk fryser på grunn av regn og kulde.

Fredag klarte en eselkonvoi i regi av lokale myndigheter fra naboområdet Ragh å ta seg frem til katastrofeområdet. Etter 24 timers marsj kunne de overlevere 5000 brød, ris, hvete, matolje og telt.
Turen ville tatt bare en halv time med helikopter. Det er den eneste matforsyningen som er kommet frem. Men behovet er så veldig mye mer.

- Forsyningen er nok til 20 landsbyer, men over 100 landsbyer er rammet, sier Youngs. Det regner mye $i$ området, og jordras giør det vanskelig for eseltransporter a nå inn til ofrene:Youngs er der-: for ilike optimîstiskimed tanke pa at folk skal kläre seg gjennom krisen Nå frykter hjelpearbeiderne utbrudd av diaré og luftveisinfeksjoner.

\section{Barn dør}

- Vi har ingen offisielle tall, men de første barna har allerede begynt å dø av sult, sier Youngs.

Shar-i-Bozurg og provinsene Badakshan og.Takhar ble verst rammet under skjelvet forrige lørdag morgen. Foreløpig regner man med at rundt 70.000 mennesker er rammet. FN opererer med 2500 døde, mens hjelpearbeidere mener tallet ligger på mellom fire og fem tusen.

Foreløpig er 45 prosent av Shar-iBozurg-distriktet undersøkt for à finne døde og sårede. Ifølge Youngs får mạ oversikt over resten uten à bruke heikopter.

\section{Samler in
penger}

Livsnodvendige ting: Afghanistankomiteen $i$. Norge begunner ná samle inn penger til de jordskjelvrammede. Styreleder Per Hornfelt i komiteen bedyrer at pengene vil bli brukt til livsnǿdvendige : : ting som vannforsyning, vaksinering og til å bygge opp ny matproduksjon.

- Vi har drevet hjelpearbeid i Afghanistan i samarbeid med FN og andre organisasjoner siden 1991. Vi har aldri opplevd å bli lurt og har heller ikke mistet penger, sier Hornfelt.til Bergens Tidende.

Med norske nødhjelpsmidler fra Utenriksdepar- tementet og Operasjon Dagsverk har Afghanistankomiteen blant annet bygd 65 skoler.

- Vi driver ikke større enn at vi har full kontroll, og vi har en liten administrasjon, sier Hornfelt.

Givere kan sende penger til:

\section{Afghanistankomiteen i}

Norge

Osterhaugsgt. 27

0183 OSLO

Kontonr. 08022017838 


\section{Dansk press}

\section{Taliban nægter at hjælpe jordskælvsofre \\ linform cution 3/6-98}

- Mens hjælpeorganisationerne arbejder på højtryk for at få nødhjælp frem til de tusinder af ramte indbyggere $i$ det nordlige Afghanistan efter weekendens voldsomme jordskælv, fortsætter Taliban-militsen deres væbnede kamp mod oppositionen i landet, og nægter at sende nøjhjælp frem til de mange ofre. Ifølge en fransk hjælpeorganisation er dødstallet nu oppe på 4.500 efter jordskælvet.

Taliban-militsen har erklæret, at der ikke bliver nogen våbenhvile under redningsarbejdet denne gang.

Ved et lignende jordskælv i februar måned i år blev fjendtlighederne $\mathrm{i}$ en kort periode indstillet.

„Vi har ikke planer om at sende nødhjælp. Vi skal først og fremmest forsvare os mod oppositionens angreb, har Talibans informationsminister," Mulla Amir Khan Muttaqi, sagt til journalister i hovedstaden Kabul.

Mandag mistede Taliban-styret kontrollen over et nøgle-distrikt efter nye kampe i det nordøstlige Afghanistan. Muttaqi anklagede oppositionen for bevidst at bruge jordskælvet til iværksætte angreb, mens landet er svagest.

Taliban hersker i to trediedele af Af- ghanistan. 45.000 indbyggere $i$ de værst ramte regioner, Rostak og Chai$\mathrm{Ab}$, er blevet hjemløse. Og mange overlevende er begyndt at flygte fra de $\emptyset$ delagte områder på jagt efter vand, mad og husly.

Nødhjælpsarbejdere har sat helikoptere ind $i$ arbejdet for at redde de tusindvis af sårede. Mange tilskadekomne er også begyndt at strømme ind på de medicinske klinikker, ankommet på æselryg eller til fods fra de svært fremkommelige ramte områder i Afghanistan. FN bad i går om yderligere hjælp til redningsarbejdet.

\section{Taleban løber fra FN-aftale $\underset{18 / 6-98}{-m_{1} / t \text { mation }}$}

FN indkaldte i går ledere fra Afghanistans Talebanmilits til hastemøde efter, at Taleban tirsdag meddelte, at man har besluttet at lukke alle pigeskoler og kvindecentre i hovedstaden Kabul.

Talebans beslutning strider mod den aftale, som blev indgået med FN i maj måned. Aftalen kom $i$ stand efter at FN i protest mod Talebans systematiske undertrykkelse af landets kvinder, stoppede nødhjælpsarbejde i det sydlige Afgahnistan.

"Det făr rystende konsekvenser for nogle af byens mest trængende folk børn og kvinder," lød det fra FN i går, der ser Talebans træk, som en klar overtrædelse af den nyligt indgåede af tale.

Aftalen indebærer blandt andet, at FN-repræsentanter og Taleban-folk mødes jævnligt for at diskutere huma- nitære emner - blandt andet også kvinders forhold. Men trods flere henvendelser fra FN har Taleban ikke reageret og lukningen af pigeskolerne og kvindecentrene, tyder på, at Taleban ikke er villig til at indgå sin del af aftalen.

Taleban har begrundet lukningerne med, at skolerne og centrene fører propaganda mod islam. Skolerne er blevet drevet af NGO'ere. 


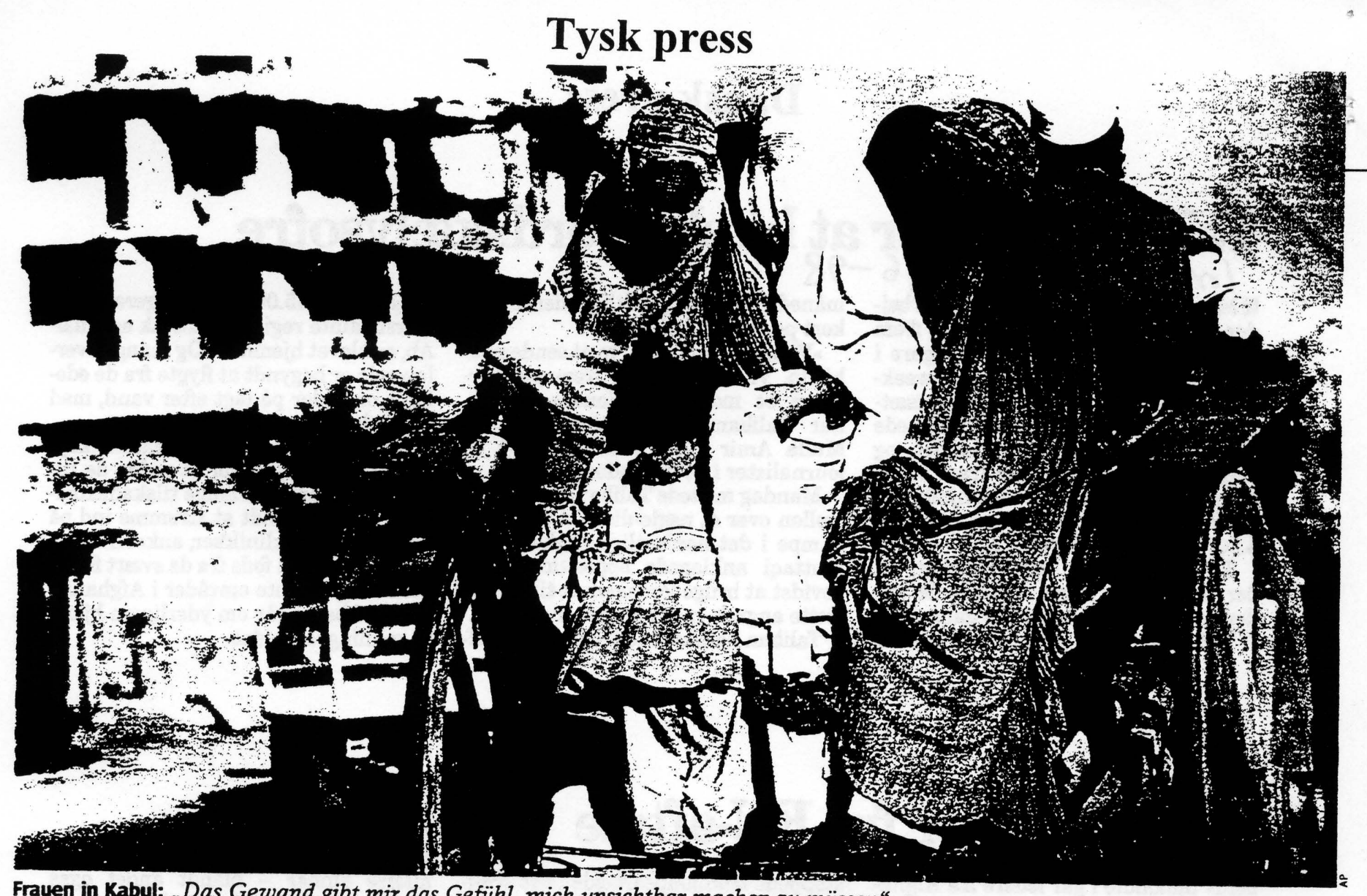

Frauen in Kabul: „Das Gewand gibt mir das Gefühl, mich unsichtbar machen zu müssen“

\section{arenanstran „Allahs furchtbarste Geißel“}

Frauen dürfen nicht arbeiten und nicht lernen, Krankenhäuser weisen Patientinnen ab: In Kabul haben die Gotteskrieger der Taliban ein mittelalterliches Regime errichtet, das die Bewohner im Namen des Islam einem gnadenlosen Terror unterwirft. Von Bernd Dörler

$\mathrm{R}$ weicht die Dämmerung der Dunkelheit, und für eine weitere - Nacht wird Kabul eine Geisterstadt. Noch bleiben gut drei Stunden bis zur Ausgangssperre um $21 \mathrm{Uhr}$, aber die Straßen sind bereits menschenleer. Nur Hunde wagen sich jetzt ins Freie. Sie suchen in den Ruinen nach Abfällen.

Der beißende Geruch von verkohltem Brennholz vermischt sich mit den Rauchschwaden, die aus Zehntausenden Schloten, Kaminen und Feuerstellen in den sternenklaren Nachthimmel steigen. Dies ist die Stunde, in der Abbas jeden Abend wieder sein Schicksal, seine Heimat und die neuen Herrscher verflucht.

Seit die Taliban vor 14 Monaten den größten Teil Afghanistans erobert und die Macht in der Hauptstadt an sich gerissen haben, in der einen Hand das Gewehr, in der anderen den Koran, haben sich der Ingenieur Abbas, 36, und seine Frau Mirjam an viel Unbill gewöhnen müssen:

An Terror und Chaos, verursacht durch einen Rat schattenhafter Reli- gionsgelehrter, die sich nur selten öffentlich zeigen und aus ihren Moscheen und Betsälen mit mittelalterlichen Geboten die Zukunft des Landes, fast zweimal so groß wie die Bundesrepublik, bestimmen wollen.

An die Allmacht von schieß- und prügelwütigen Milizen, die sich Taliban („Stu-

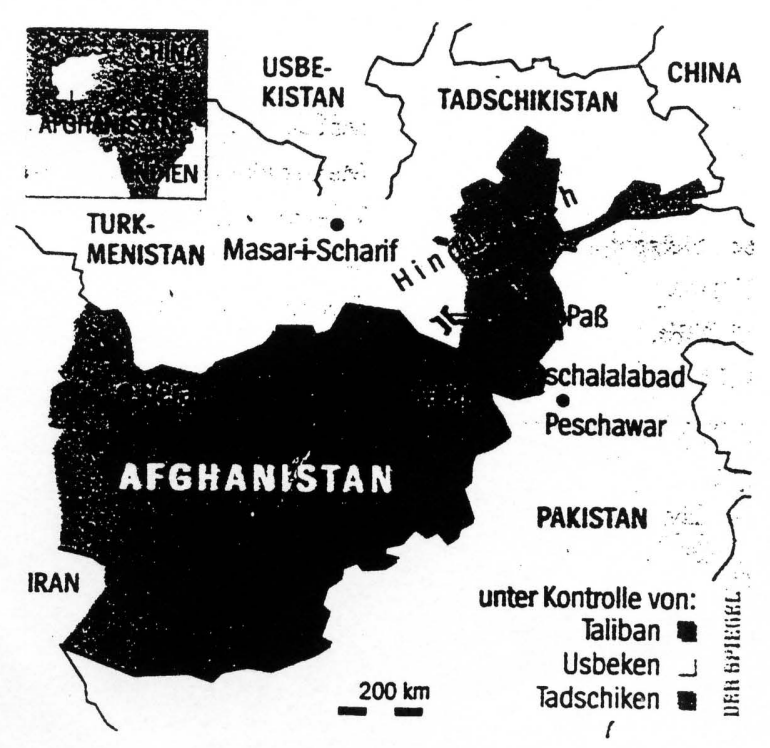

denten ") nennen, meistens aber weder lesen noch schreiben können. Und an eine Regierung, die seit sieben Monaten keine Gehälter mehr zahlt, obwohl sie praktisch einziger Arbeitgeber der Hauptstadt ist.

Angstvoll gehorchen Abbas und Mirjam den Befehlen, sogar in den eigenen vier Wänden. Sie hören in ihrer Plattenbau-Wohnung im einst von den sowjetischen Besatzern errichteten Stadtteil Mikroravon keine Musik mehr, sehen sich die beliebten Videos mit indischen Liebesdramen nicht mehr an - beides wird von den Taliban als "gottlos:" verteufelt. Sonst noch auf dem Index: Kino, Theater, Tanzen und Singen bei Hochzeiten sowie Fotografieren, weil der Islam die Menschenabbildung verbietet.

Auch die strenge Kleiderordnung, die für alle Bewohner der Millionenstadt gilt, haben die beiden akzeptiert. Statt Sakko und Jeans trägt Abbas die traditionelle PaschtunenTracht „Perahan“ und „Tonban“, ein knielanges Hemd und darunter eine Pluderhose. Außerdem mußte er sich einen Vollbart wachsen lassen; seinen 


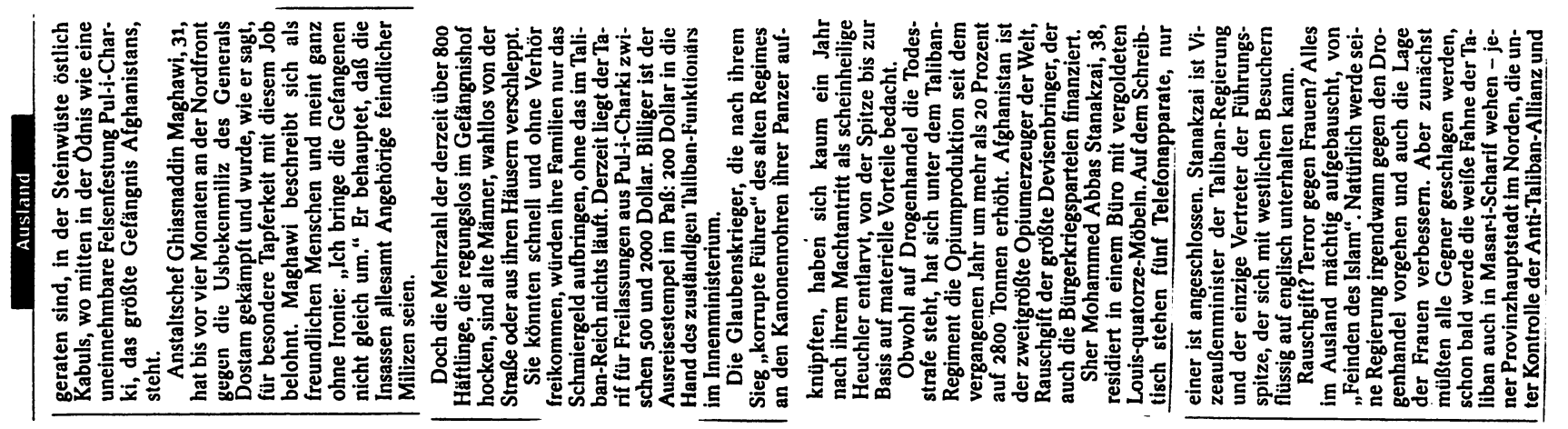

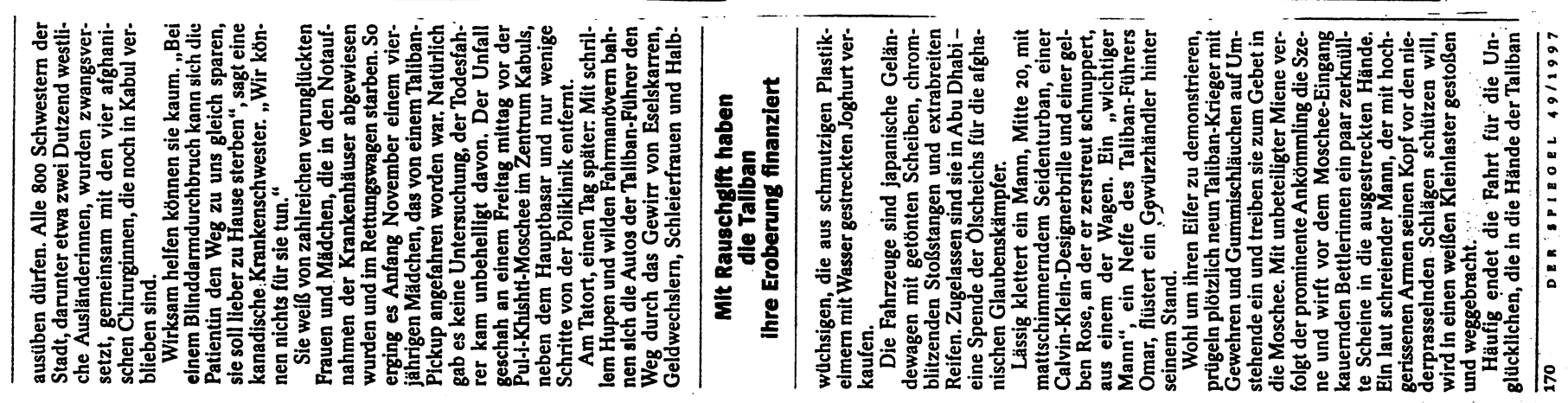
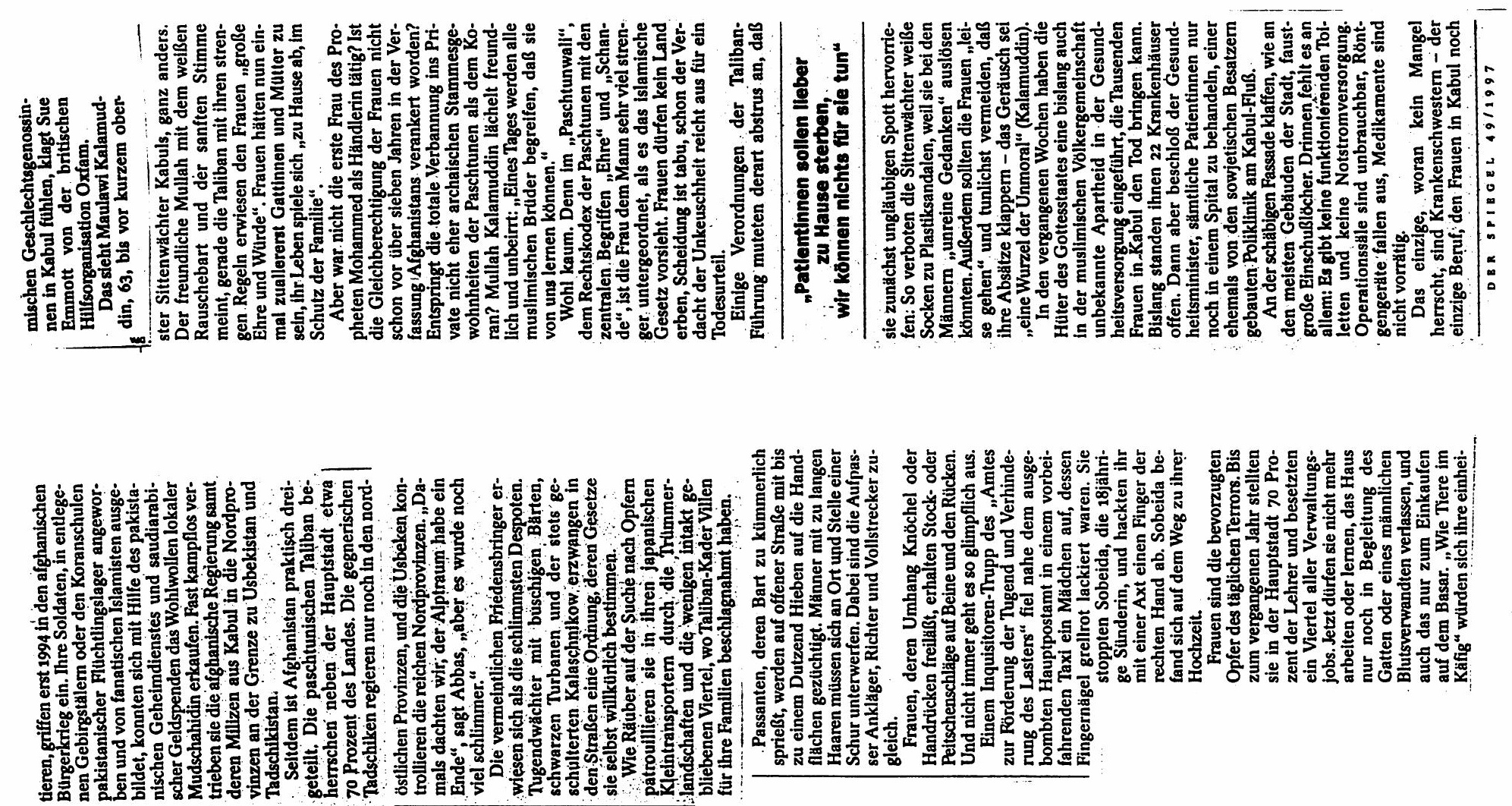

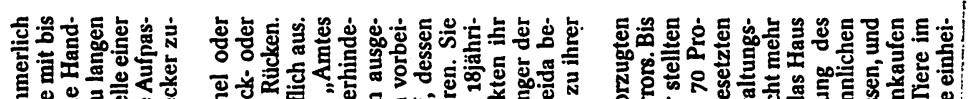

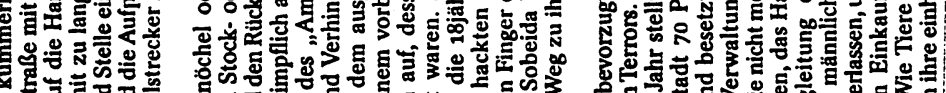

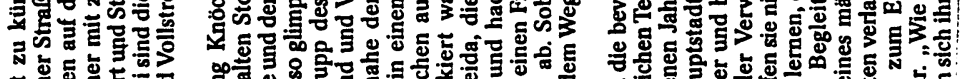

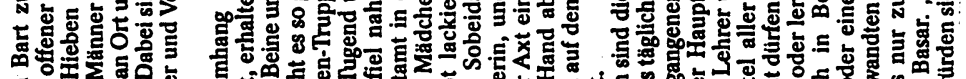

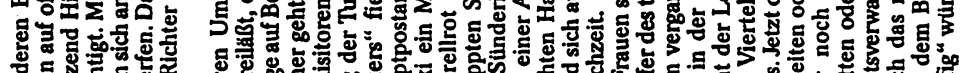

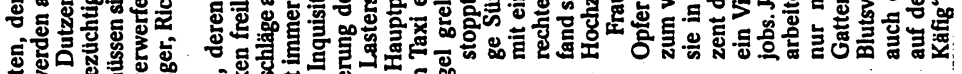

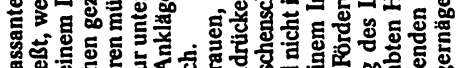

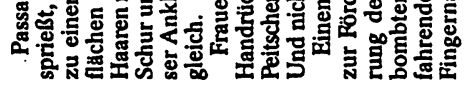

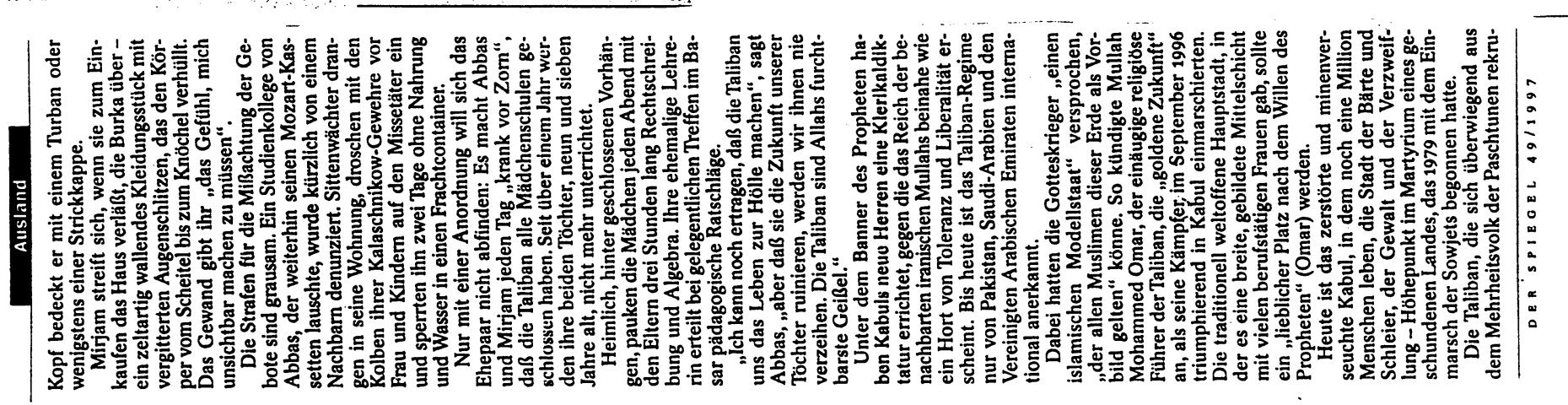


der aus Kabul geflüchteten Regierung steht.

Die zur Schau gestellte religiöse Inbrunst und die radikalislamische Rhetorik der Taliban können nicht verbergen, daß eigentliches Ziel nicht allein die Errichtumg eines Gottesstates ist s vor al lem auch um die ethnische Hegemonie de Paschtunen im afghanischen Völker- und Stammesgewirr.

Die hochgewachsenen und hellhäutigen Paschtunen traten am Hindukusch stets als Herrenmenschen auf. Sie beziehen bis heute $\mathrm{ihr}$ ausgeprägtes Sendungsbewußtsein aus ibrer glomracter die britische Kolonialarmee vermochte den legendären Kriegerstamm nicht zu unterwerfen. Die Taliban träumen von einem großpaschtunischen Reich, das bis an die Ufer des pakistanischen Indus und bis zum zentralasiatischen Samarkand reicht - mit Kabul als Zentrum

Trotz der ehrgeizigen Pläne fanden sie stille Förderer in Pakistan, wo auch zehn Millionen: Paschtunen leben, und in den Millionen: Paschtunen leben, und in den
USA. Washington setzt darauf, da $B$ die neuen. Herren im großen Spiel um die Macht zwischen Kaukasus und Pamir ein wichtiges Bollwerk gegen Iran bilden könnten. Geplant ist der Bau einer Ol- und Erdgaspipeline von Turkmenistan über Afchanistan nach Pakistan das wenig Ol Af政 Erdgas besitzt und Afghanistan als Brücke zu den zentralasiatischen Märkten braucht:

Ohne Hilfe der Vereinten Nationen und ausländischer Organisationen wie des Internationalen Komitees vom Roten Kreuz oder der deutschen Welthungerhilfe wäre Kabul, so ein französischer Arzt, "schon längst eine Totenstadt".

Die Ausländer versuchen, ihren bescheidenen Einfluß zu nutzen. So sollen Frauen wieder in allen Krankenhäusern Kabuls bewandelt werden. Ein Expertenteam derWeltgesundheitsorganisation will diese Woche gesundheitsorganisation will diese. Woche gung in der Hauptstadt veröffentlichen.

Vor Einbruch des Winters, der sich im 1800 Meter hoch gelegenen Talkessel bis spät in den Mä für die meisten Bewohner der Hauptstadt für die meisten Bewohner der Hauptstadt dramatisch zugespitzt. Immer öfter setzen verzweifelte Eltern Neugeborene an den
Pforten der Moscheen aus. In den Spitälern häufen sich Fälle von Tuberkulose, begünstigt durch Unterernährung.

Der Möbeltischler Madschid aus dem Stadtteil Wazir Akbar. Khan hat Frau und vier Kinder zu versorgen und weiß nicht mehr, wie. Aufträge für-seine Spezialität mehr, wie. Aufträge für-seine Spezialität,
kunstvoll verzierte Holzstühle, bleiben seit Monstvoll verzierte Holzstühle, bleiben seit Monaten aus. Die Ersparnisse sind aufge-
braucht, auch der Hochzeitsschmuck der Frau ist längst verkauft.

Vor einem Jahr um diese Zeit konnte er noch entscheiden, ob seine Familie hungern oder frieren" mußte "Doch nun" so Madshid " Madschid, "haben wir diese Wahl nicht

DER SPIEGEL $49 / 1997$

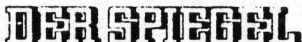

\section{DAS DEUTSCHE MACHCHEN MACAZIN}

\section{Hausmitteilung}

\section{Dezember 1997}

Betr:: Leserbriefe, Kabul, Heine

$A$ ls sei da ein Damm gebrochen: Selten zuvor äußerten sich die SPIEGEL-LeAser so vehement und in so großer Zahl wie nach dem Titelstück, das Reporter Matthias Matussek über die weithin verdrängte Problematik der "vaterlosen $\mathrm{Ge}$ sellschaft" geschrieben hat - guter Grund nun für die Kollegin Petra Kleinau, damit den kompletten Briefteil dieses Heftes zu bestreiten. Mehr Männer als Frauen meldeten sich, viele schilderten ihren eigenen Kampf ums Kind und bestürmten dann Kleinau telefonisch, das doch auch bitte zu drucken. Ein verständlicher Wunsch, dem freilich der Briefteil nicht gewachsen ist.

Das Telefon blieb auch beim Autor nicht still. Matussek wiederum, der nach seinem provozierenden Beitrag mit allem gerechnet hatte, erhielt überwiegend Anrufe von Frauen - und die meisten zollten ihm Beifall: erwachsen gewordene Scheidungskinder zum Beispiel, die unter dem Vaterentzug einst selber gelitten hatten.

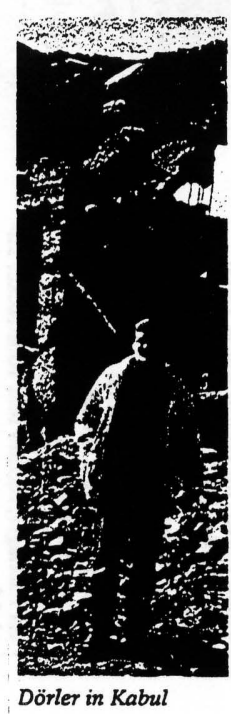

in Kabul
T eicht war es nie für Journalisten, in Afghanistan zu arLbeiten, und SPIEGEL-Redakteur Bernd Dörler hat das oft genug erlebt. Er berichtete über den Einfall der Sowjetarmee 1979 und 1992 vom Triumph der Mudschahidin, die nach blutigen Stammeskriegen die Oberhand behielten. Nun war Dörler wieder in der Hauptstadt Kabul - unter Bedingungen, wie er sie nicht kannte. Fotografieren war ebenso verboten wie der spontane Kontakt zu den Menschen; Privathäuser durften erst gar nicht betreten werden, und von morgens bis abends blieb ihm ein Aufpasser der Staatsmacht auf den Fersen. Dörler gelang es immerhin, in einem Gästehaus im Zentrum der Stadt unterzukommen - statt in dem außerhalb gelegenen Hotel, in dem Presseleute für gewöhnlich kaserniert werden. Und zwischen Einbruch der Dunkelheit und dem Beginn der Ausgangssperre konnte sich der SPIEGEL-Mann ein Bild machen von der Klerikaldiktatur, die nun das Volk und vor allem die Frauen drangsaliert. Unter den Gottesund vor allem die Frauen drangsaliert. Unter den Gottes-
kriegern der Taliban herrscht in der einst weltoffenen, jetzt zertrümmerten Metropole nackte Willkür. Wer die falsche Musik hört, zum Beispiel Mozart, wird mißhandelt und eingesperrt und kann dabei noch froh sein; einer jungen Braut, die es gewagt hatte, sich die Nägel rot anzumalen, wurde au dem Wege zur Hochzeit ein Finger abgehackt. Im Namen Allahs (Seite 166). uf dem Gymnasium, das Titelautor Rudolf Augstein in der Nazi-Zeit einst besuchte, kam Heinrich Heine nicht vor. ein unerwünschter Dichter, über den man nichts wissen mußte. Und noch etliche Nachkriegsjahre sollte es dauern, bis Augstein zu diesem schwierigen Schriftsteller fand - der ihn dann nicht mehr losließ. Ein Buchprojekt entstand, blieb aber unverwirklicht, doch wer immer bei Augstein auf Heine kam, durfte sicher sein, einen kenntnisreichen Gesprächspartner vor sich zu haben. So erklärt es sich wohl auch, daß ihm letztes Jahr von der Heinrich Heine Universität in Düsseldorf eine Gastprofessur für den sogenannten Heinrich-Heine-Lehrstuhl angeboten wurde - einen Lehrstuhl, der nach den Worten des Rektors Professor Gert Kaiser "keineswegs der Literatur oder der Literaturkritik reserviert bleibt", sondern auch Raum läßt für "Politik, Wissenschaft und öffentlichen Meinungsstreit“, eben in der Weise, „wie in der Aufklärung der Begriff Kritik verstanden wurde“. Augstein mußte ablehnen, mit einigem Bedauern, er hat beim SPIEGEL zu tun. 


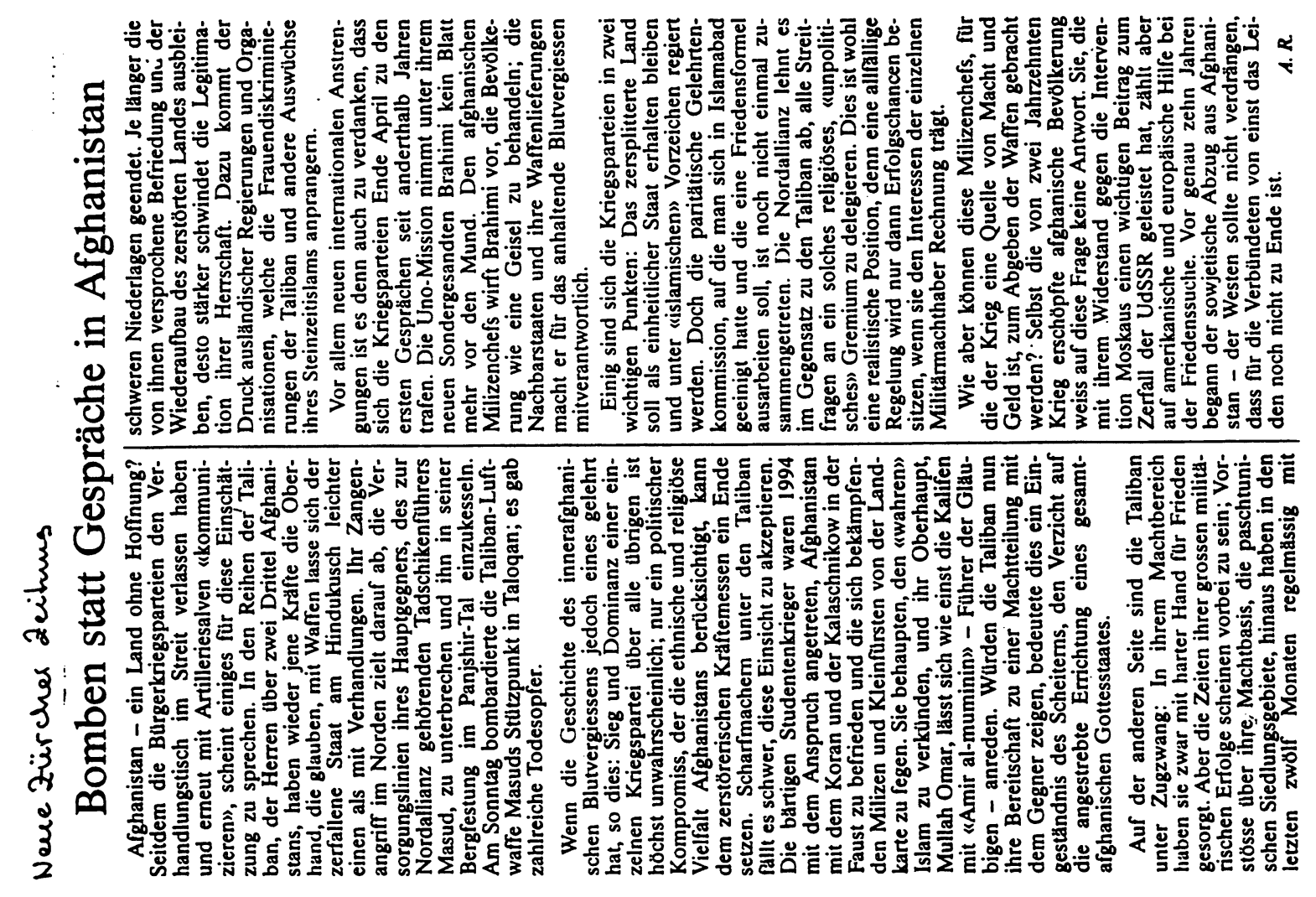

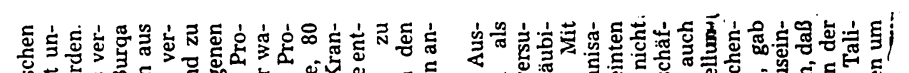

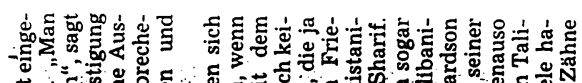

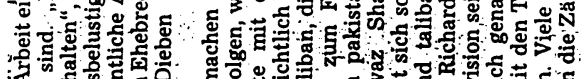

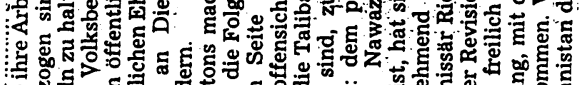

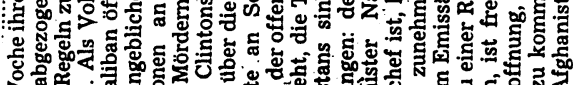

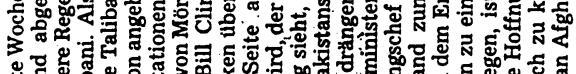

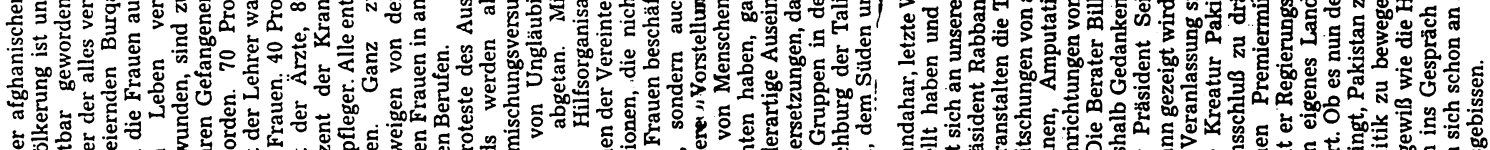

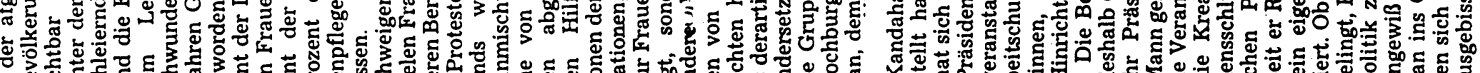

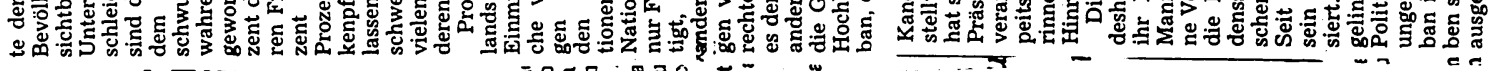

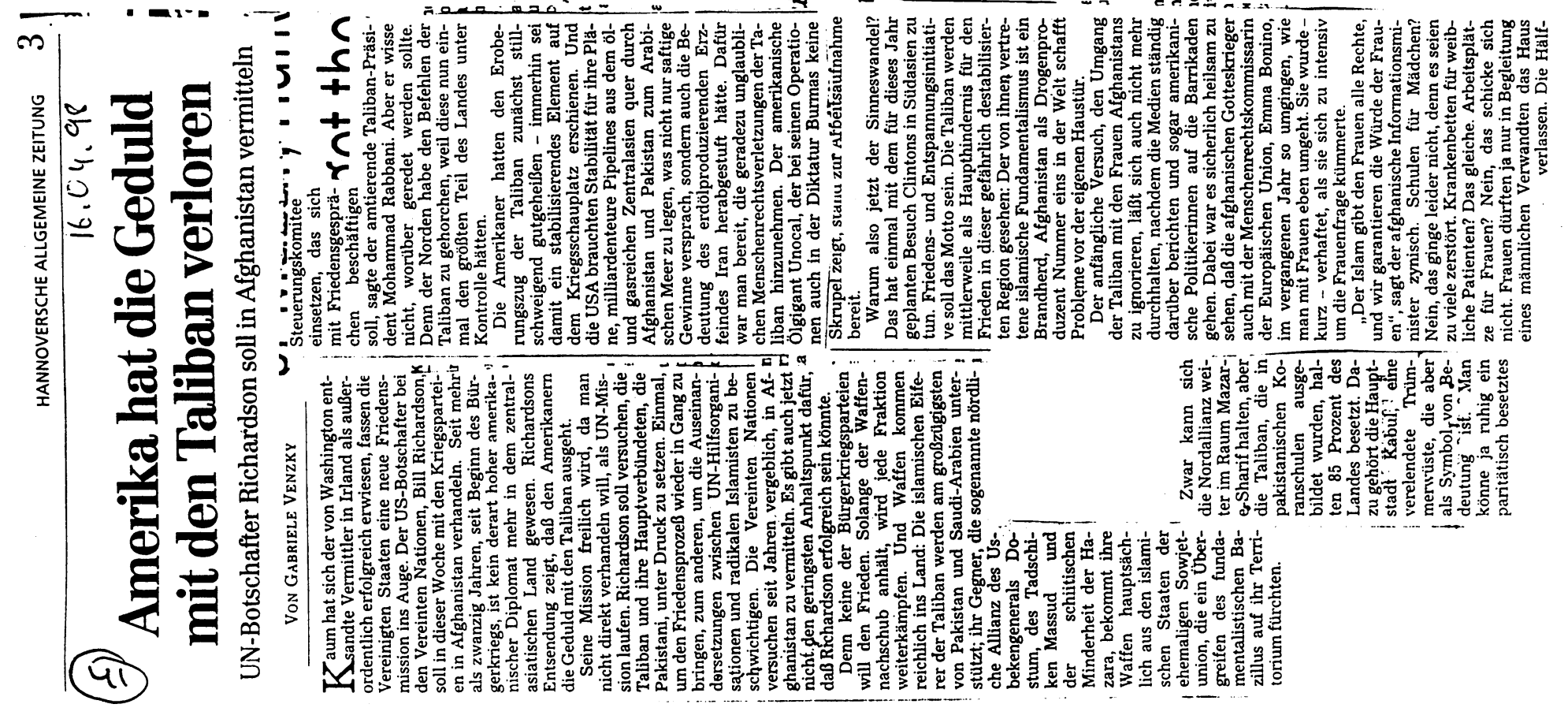



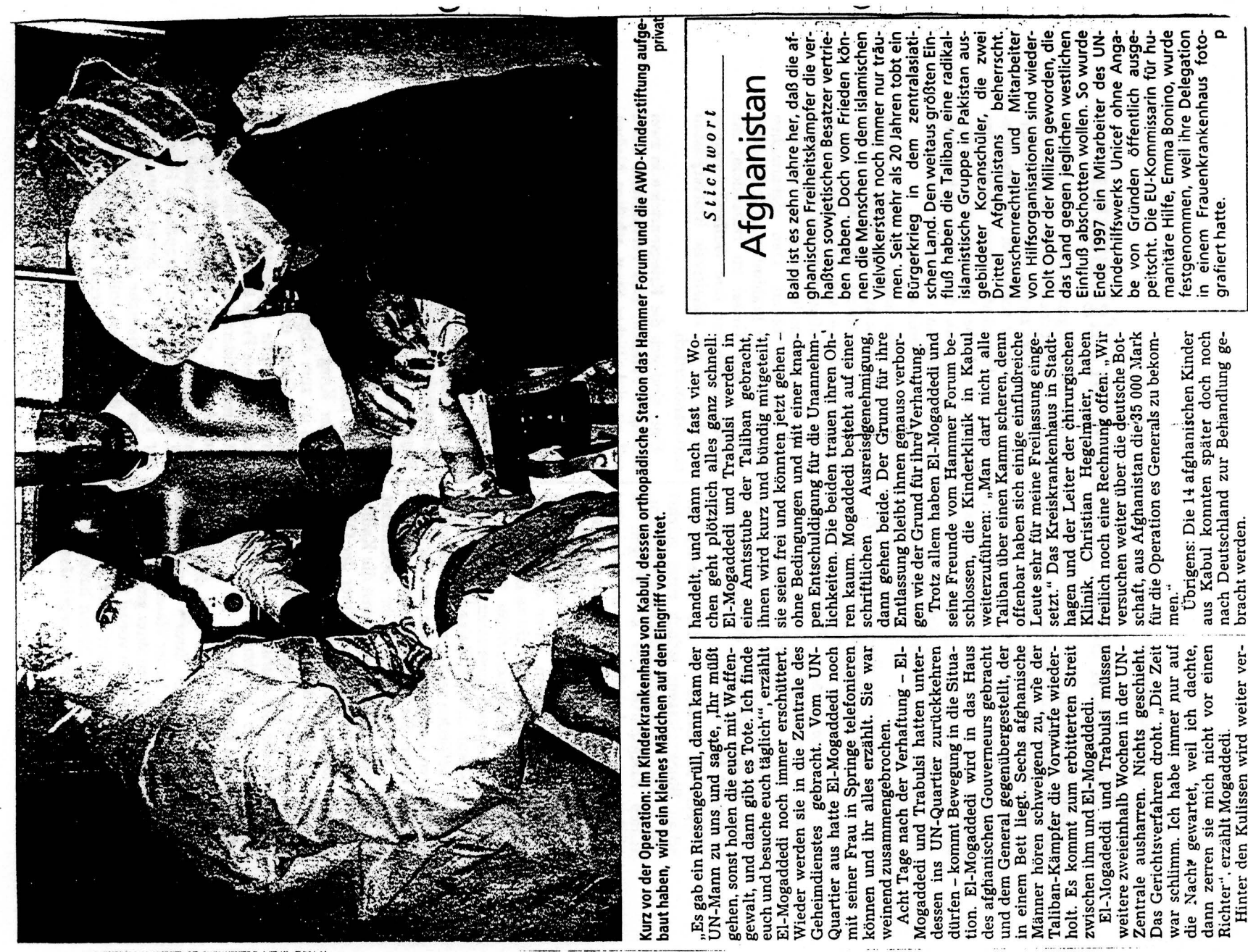

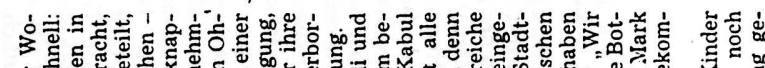

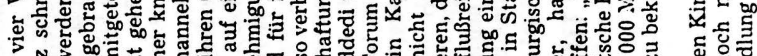

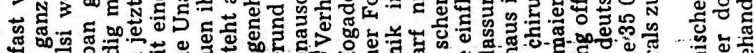

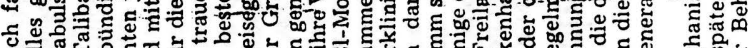

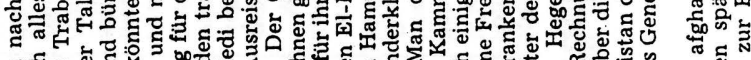

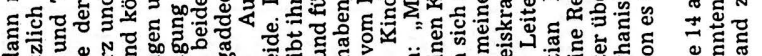

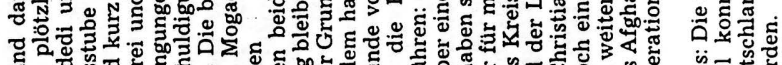

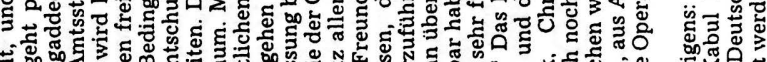

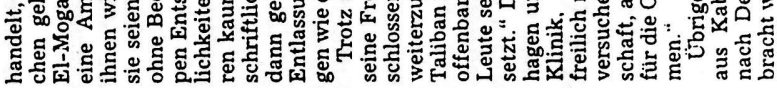

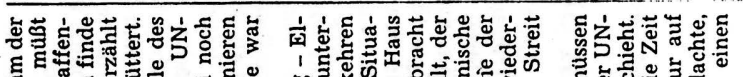

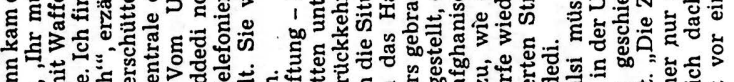

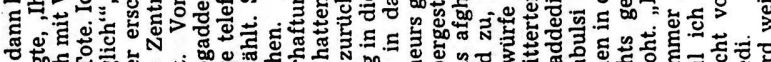

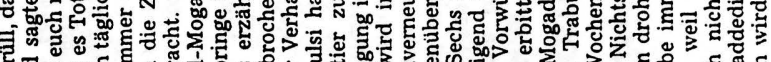

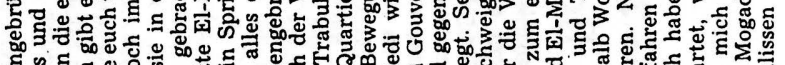

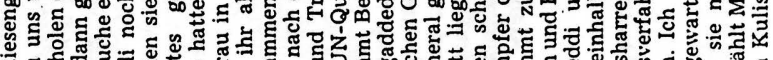

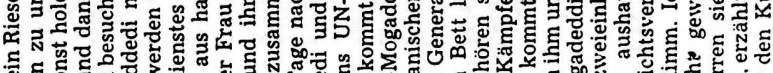

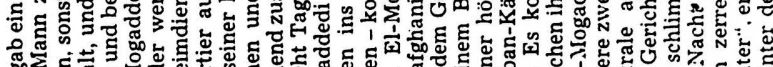

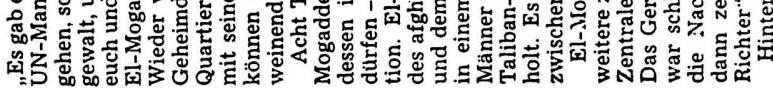

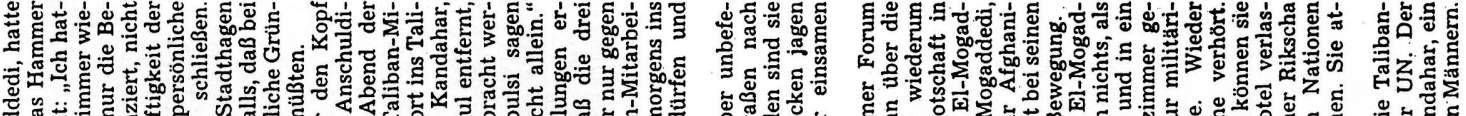

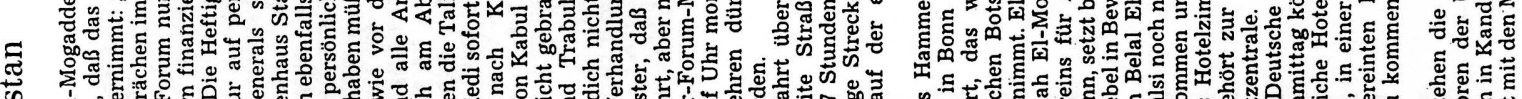

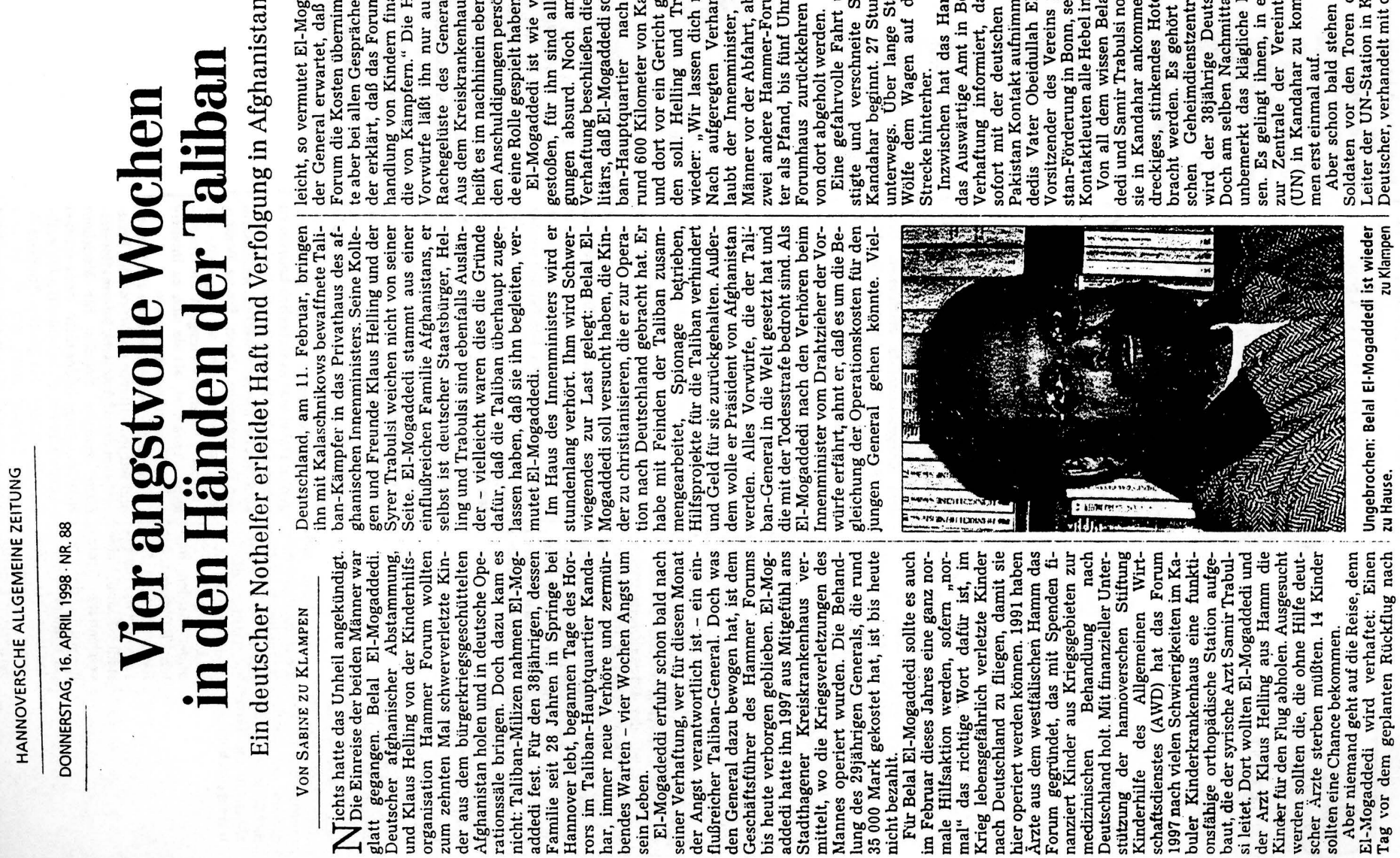



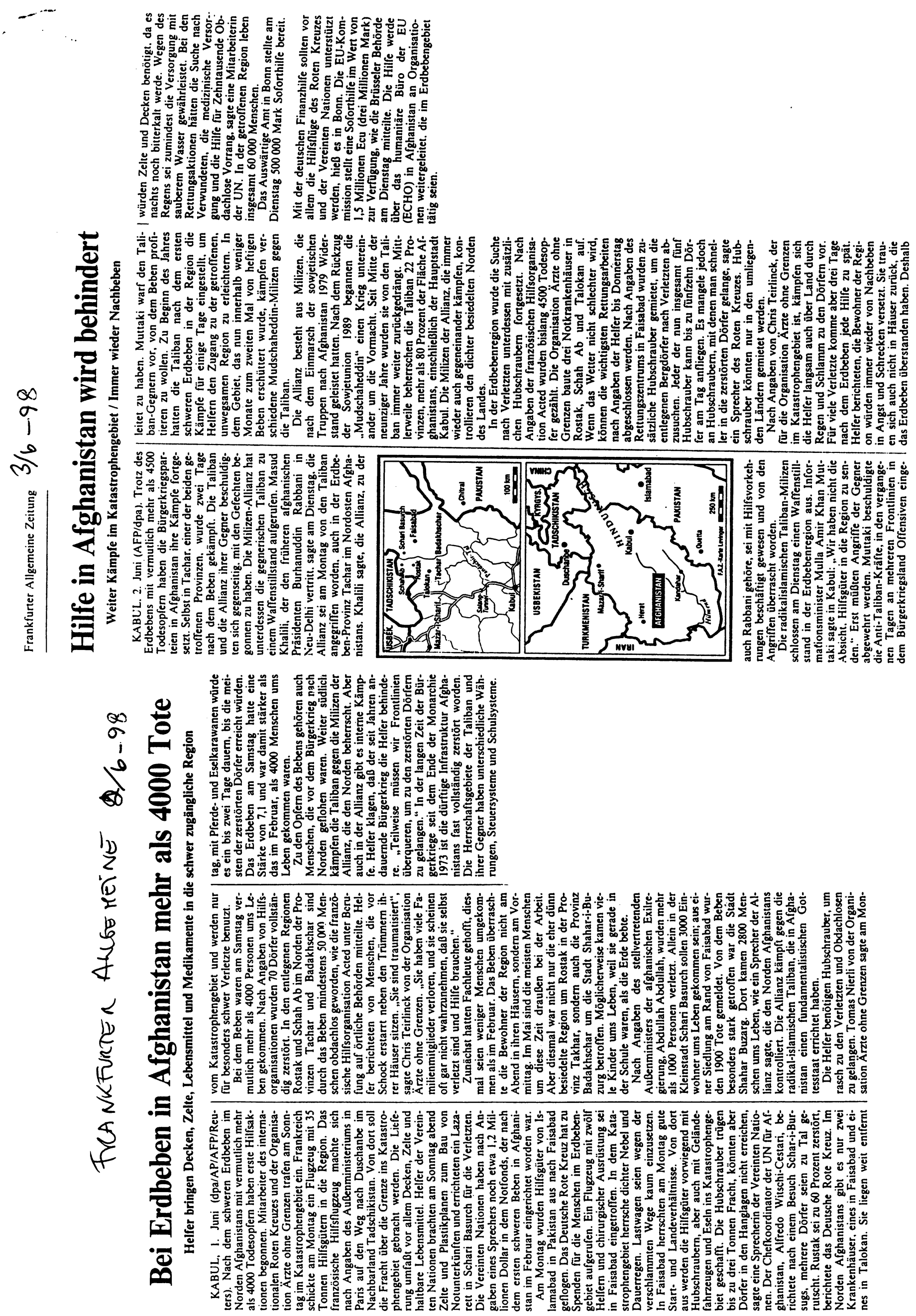


\section{Für Kabulerinnen ist die Welt zusammengebrochen}

AFGHANISTAN/Was sich bereits unter dem Mujahedin-Regime abzuzeichnen begonnen hat, ist mit der Machtübernahme der Taliban endgilltig geworden: Die Kabulerinnen sind aus dem offentli- chen Leben verschwunden. Anders als der Grossteil der Frauen in Afghanistan hatten sich die gebildeten Städterinnen an gute Ausbildung und Erwerbsarbeit ausser Haus gewöhnt.

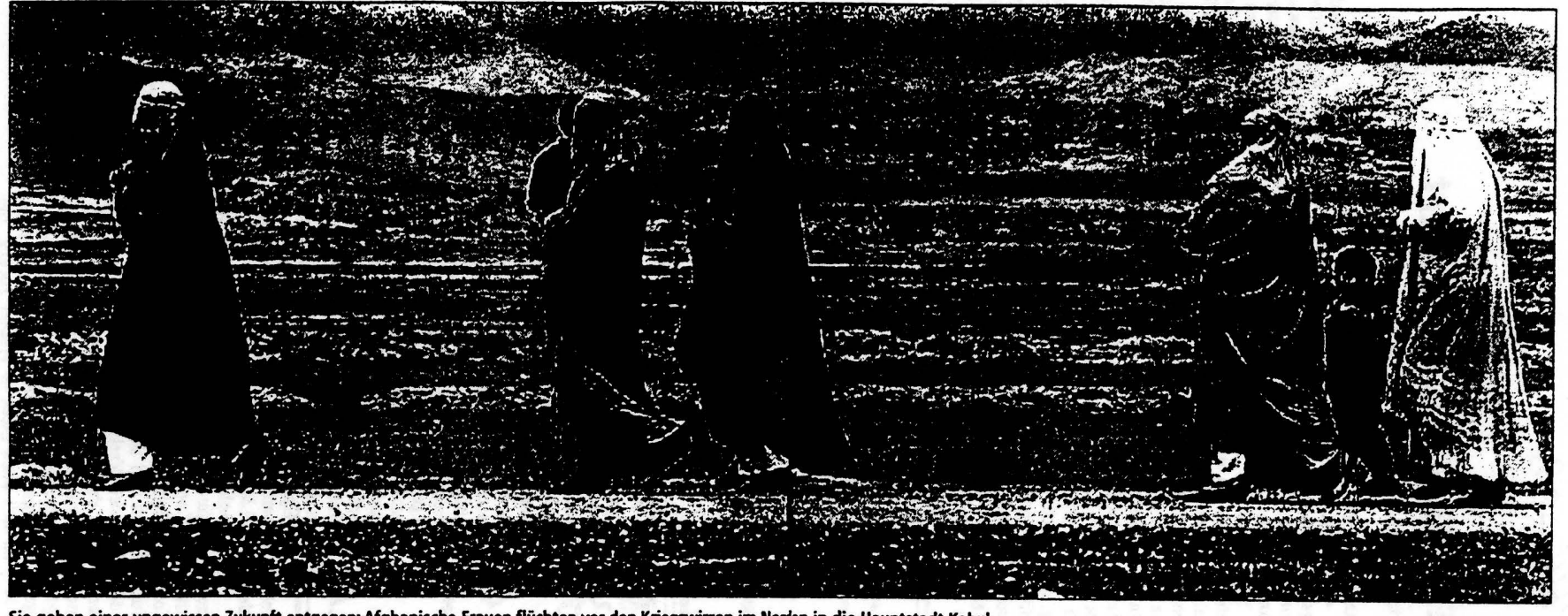

Sie gehen einer ungewissen Zukunft entgegen: Afghanische frauen flüchten vor den Kriegswirren im Norden in die Hauptstadt Kabul.

Den Bun el $1975-98$

KARIN REBER AMMANN

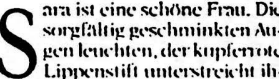

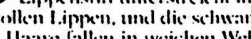

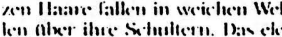

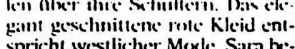

spricht westlicher Mexde. Sara be.
finclet sich in ilrem Borto, wo sic

finclet sich in ihrem Barto. Wo sie
als Obersetzerin fur cin Hilfswerk

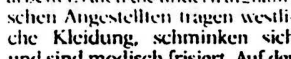

und sind modisch frisiert. Auf der

Strasse jedexch, im Hernschaftsho-
reich cler Talihan, sehen sic so aus

wie dies die neuen Machihaher in

Kabul verlangen: Unter der Bury:
sersterkt, diesem reltartigen. his

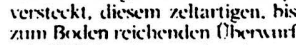

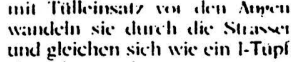

und gleichen sich wie ein 1-Tupi
chen dem andern - pritsent und

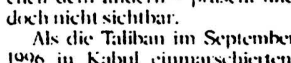

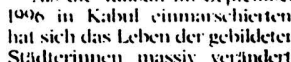

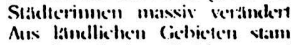

mend und olme bitlahmung mit
dem Lecten einer Grossstadi ser.

langten die meist hlus jungen Tali

wals ihrer pass htunischen Tradi-

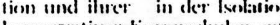

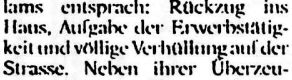

gung. dass cine unversehleierte
Fran in der Offendliclikcit menza-

lisch suspekt sei. Ixyertnden dic
Taliban ilue strikten Regello auth

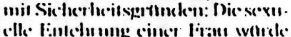
nicle nur deren Familic, sesndern das ganze Regime beflecken.

Andere Welt

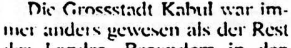

Met anders geweren als der Rest
des Landes. Besonders in den sechziger und siebziger Jahren entstand hier cine eigentlich west-
liche Kultur. Aufenthalte in Europa gehorten ebenso mum Alltag

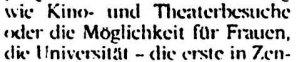

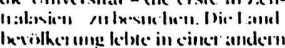

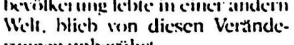

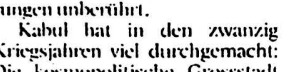

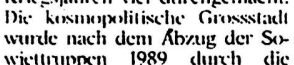

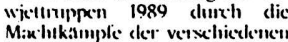
Mujahedin-Fraktionen ru drei
Vierteln zerstort. Dic Elite hatte Vierteln zerstort. Dic Elite hatte
dias I iand liangst verlassen, und ric-

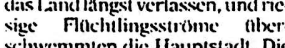

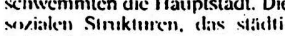

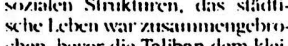

nen Oberbleibscil. das sic als stadlische Dekakieny. betracliteten. achitlicher Freiheit bewegen kom. Sara erinnert sich daran, wie ter und Tochter in arbeiten MotSara crinner sich daran, wie ter und Tochter in der Burqa ge-
schwierig das Tragen der Burqa meinsam mit ihren am Anfang fur sie war. Stunden- den Feldern. Wichtigstes Ziel der lang thbte sic muhause, wic sic sich

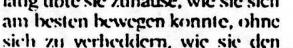

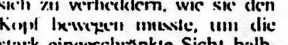
stark eingeschrankte Sicht halb-
wegs wettzumachen. Der Stress wegs wcttzumachen. Der Stress
auf der Strasse war enorm: \&ich hatte beim Strassenuberqueren Angst. nherfahren ru tireden."
Inzwischen schreitet sie, dic sich von fruher her nur gewohnt war, den Kopf mit einem farbigen Foulard zu bedecken, in ihrer zart. blauen Burqa aus Kunstseide beit kann sic es sich leisten, ctwas mchr Geld auszugeben und ein Burqa aus angenchmem Stoff 70 viet in eincer Stadt in der die met.

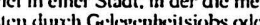
Belleln niche methrals cinen Fran ken tăglich einnehmen.

Anderis als for die ged bikleten
Stadterinnen ist fur den grosste Teil der Franen in Afghanistan das Tingen der Burya nichts Nelles.
Die victen Fluchtlinesirauen, dic aus landlichen Gebieten stam men, tragen die Burqa scit Jahr als die strikte Geschlects anderes nung. Aur dem liand lecentren litaten neist in ietheren, ve
Frauen auf dem Land ist es. Mut-

ter zu werden. Dunch dic Mutter-

cit und dic effiziente linlut des Haushaltes erreichen sie Sta-
us und personliche Erfollung. Die Nomadinnen Erfullung.

die mit ihren grossen Viehherden die fruclutbaren Elycnen zikehen. tragen keine Burqa. Sie entspricht nicht ihrer Tradition, warde sie zu stark bei ihrer Arbcit, beim HerHohe Analphabetenrate Dic meisten Afghaninnen hatn nicmals dic Moglichkeit. in dic Bevolkelung sind Altalphalx n.cht gekerordic Taliban an en grossten Teil der Frauen un oglich, auch nur an cinen Schu-

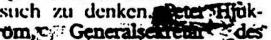
iwedischen AfghanistankomiS, nennt die Tatsache, dass 20 d, eine Revolution fur die landhen: Gebiete: ivor dem Krieg ren nie aber zehn Prozen dchen in den Schulen.

omis schwedische Afghanista gmiltee ist die wohl grosste Nicht-

\section{Werkzeuge in den Händen der Männer}

FRAUENBILDER I Ob sie Imun traditionalistische oder modernistische Ansichten hatten - seiAAnfang dieses Jahrhunderts warcn es immer die. Mëmner. welche die Rolle der Fran in der afyhanischen Gesellschat definierten.

krat. Dit Framen in Kaluul lathen

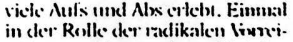

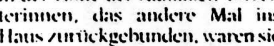
immer nur Svinbric der Wiettan-s schamung des jeweiligen Her
schers: Srowehl die Traditionalistenwie atudhdic Mexdernistende-
rinierten die Rosle der Fram finierten die Rolle der Fram sin
dass sie ilarer Vision cines ickaien Stiates entspmich. Dic restriktiren Bextimmenngen der Talihan sind cin woileres (Glicd in sh muleviuncen. dic Anfant dine

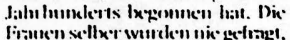

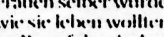

inc l:inlacit. Virschiedene lath.

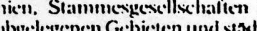

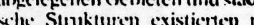
|xincinauncker. Immer wiecks kame"l die Spammungen awisethen

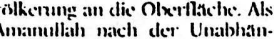
pigkeit 1910 erster Konig wurke. :mbitiobsen Mexdemisiculungsplan auf die Frauen als Stmbrile
ceiner neuen Ordnung. Sein seiner netuen Ordnung. Sein
Fratuentechtsprogramm and unter dem Einfluss der modertistischen Beweygungen
Torkei, Iran und Agvplen.

Brautgeld verboten sellinthertlich, nich dien keis-

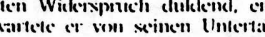

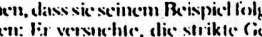

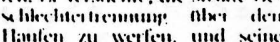

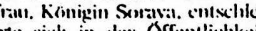
Das netue Familiengeset\% unter-

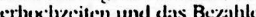
cines Brautgeldes.
Mönglichkcit, ihren Ehemann scelmiann sel- unien - wiecker einen Auf-

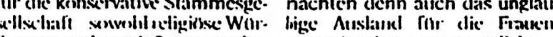
dentidger als auch Stammestiliste lehnten sich auf gegen den $\mathrm{Au}$ Der Widerstand gegen die So(ic 1979 in Afghandien rackgangig mowen: Offentlich Madocis schlossen, und die Frauen mussten sich auf der Strasse wicder versehleciem. Als Amanullah 192 gexilinzal wurck: war dic Emanzipallien auf hallhem Wey slecken Konip 7ahlir Slanl, der bis 195

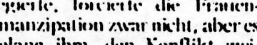
schen Steali und Land to stabilisieren. In der Folge entfernte sich dic stacltix he Benslkerung im iner starker won ckn Stammestro ditionen. In den sicbziger Jahre
Wandlichen Gebiets Eeftinhrt: 340 Kriaben-, $125^{\circ}$ Madchen- " ind 100
gemischic Schulen. 6000 Afghathen sind for das Komitee im Bildungsbercich tatig, 900 daven Lehrerinnen.

Kinderrechte

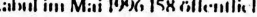
Schulen. Darin wurden 150)(00) Knaben und 100000 Mädchen vin 1000 Personen unterrichilet. Knapp 8000 davon waren Lehre.

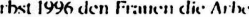
ausser Haus verbuten, brach de Schulbetrieb zusammen,

Sara erinnert sich an die ersten Schultage ihres siebenjahrige Sohnes: «Es hat an allem gefehlt an Stahlen, Buchern und am Lehrpersonal. Inzwischen unter-

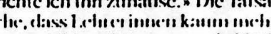
unterricluten kesment und M:klen uber neun Jahre niclt mel 政 en Colin Tucker denn auch nich cinfach cine Art der Frauenunlerdruckung, sondern vielmehr cin Frage der Kinderrechtc: Das Lehrpersonal an den Primarschuic war meist weiblich. Die wenige sind, tauchen nur unregelmassi auf, da sie in den vergangenen

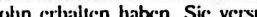
hen sich mit (ieleygenlicitsurlye
len uber Wasser zu halten. Das Bi

\section{Geburtshilfe}

kra. Dic Suuglings- und Kincler sterblichkeit in Arghanistan getor pemass Geburten sterben 257 Kinder his fonfjaktig. Auch dic Matter derch 60 Proyent der Geburten

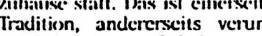
moglicht dic nachtliche Aus gangssperre viclen Frauen de Spitalbesuch. Dic gebarenden dige Hilfe auskommen, betreu von ihren Schwiegermattem oder andern Frauen der Familic. Terre-des-Hommes-Delegic te Annaluelle Shaerer nennt als nen der llauptgronde for die vielen Komplikationen die man-

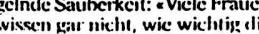

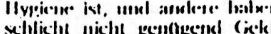
un cin Stack Scife uder cin satun cin Stack Stife ixcer

Hier setzt das Mutler-Kind Projekt won Terre des Ilomme an. Seit 1996 besuchen vem an. Seit 1996 besuchen vom derver han der Taliban la: mulcen Sclumbicher kaum mehr verwien det werden konnen: Dic Bilder auch in Teil des Textes.

Untergrundschulen

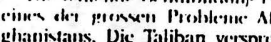
chen zwar immer wieder, dass sic die Lage beruhigt habe und ge(1) Sara. - Deshalb. schickt. sid, sagt Tochter in eine Unvergrundschuc. Veje Lehrerinnen haben das Arseitwerbot unterlaufen, indem zimmer eingerichtet haben. Tagwichten sie clest cwanyig.

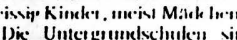
for tiele Ledrerinnen die cinzige Mänglichkeit, inil ihrem froblecter) Und for vicle Kinder sind sie die cinrige Chance, cine nudimentar Dic Talla zu erhalien. Die Talihan wissen, dass es solchess ben und Madchen terrichtet werden. Es soll sngar Talihan geben, dic ihre Kinder in Untergrundschulen schicken. S lange dix- Koransturelenten iht (c. moglich in Kabul.

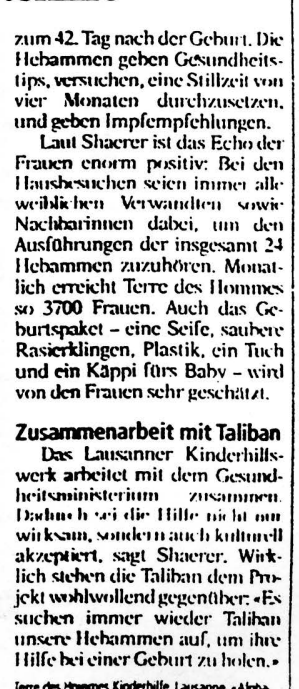

7um 42. Tag nach der Gchurt. Dic lips, versuchen, cine Stillzeris sem und geten Impfempfehlungen. Laul Shacrer ist das Ecches der lausheyuchen pusitiv: Bei den Ausarmen der insgexamt 24 buranaket - eine Scife, suhe und in Kan, Plastik. cin Tuk 


\section{Ein Leben ohne Gesicht}

Wofür Frauen aller Länder jahrzehntelang kämpften, machten die Taliban in Tagen zunichte:

Sie verboten den Afghaninnen zu arbeiten und zu studieren. Immer mehr versuchen, dem Sklavendasein zu entkommen - durch Selbstmord oder Flucht. Von Anuschka Roshani

$\mathrm{E}$

ines Morgens war Jamila* aufgewacht, mit der schrecklichen Gewißheit, von nun an nur als ein Schatten weiterleben zu können. Erst wenn die junge Biologie-Dozentin für die Bärtigen da draußen kein Gesicht mehr hätte, erst dann würde sie von ihnen in Ruhe gelassen werden. „Diese Männer sind wie Tiere, ungebildet und brutal",

- Name von der Redaktion geändert. sagt Jamila. „Sie verachten die Menschen."

Vor anderthalb Jahren haben die Taliban Kabul erobert, militante junge Kerle, die nur eine Mission kennen: der modernen Hauptstadt die Scharia, das islamische Recht, zu bringen. Sie waren nicht einmal 24 Stunden an der Macht, da ließen sie die Muezzin von den Minaretten die „Islamische Revolution" verkünden. Und Jamila hörte in Radio Afghanistan, das von da an
Radio Scharia hieß, daß es allen Einwohnerinnen ab sofort untersagt sei, ihrer Arbeit oder ihrem Studium nachzugehen. Keine Frau dürfe von nun an ohne ihren Ehemann, ihren Vater oder Bruder das Haus verlassen - aber auch dann nur von Kopf bis Fuß verschleiert. Und die Krankenhäuser würden für Frauen geschlossen, hieß es - auch ein kranker weiblicher Körper könne für die Ärzte zu einer Verführung werden. Innerhalb einer Woche

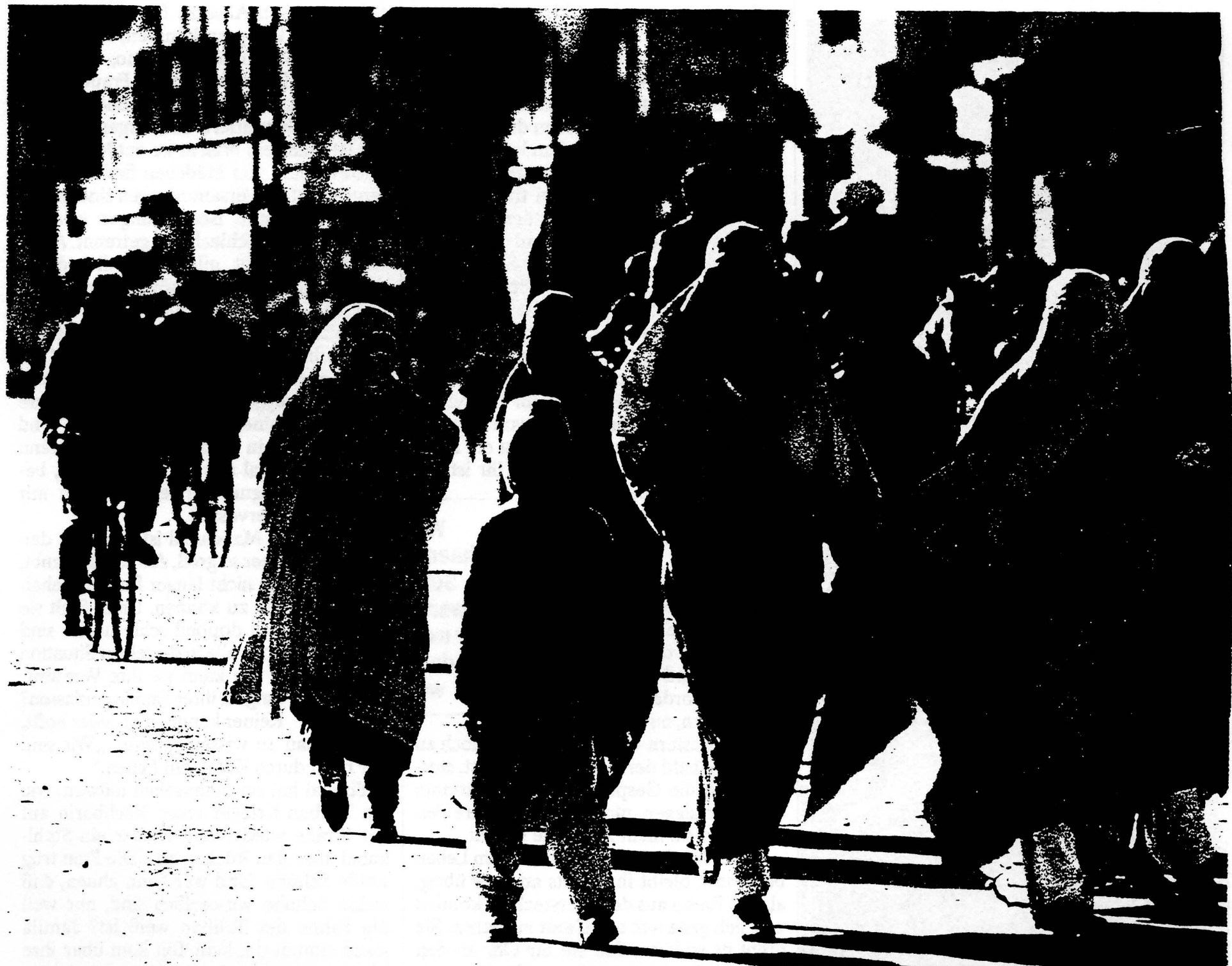

Verschleierte Frauen in den Straßen von Kabul: Innerhalb einer Woche verloren sie alles - ihre Jobs, ihre Rechte, ihre Zukunft 


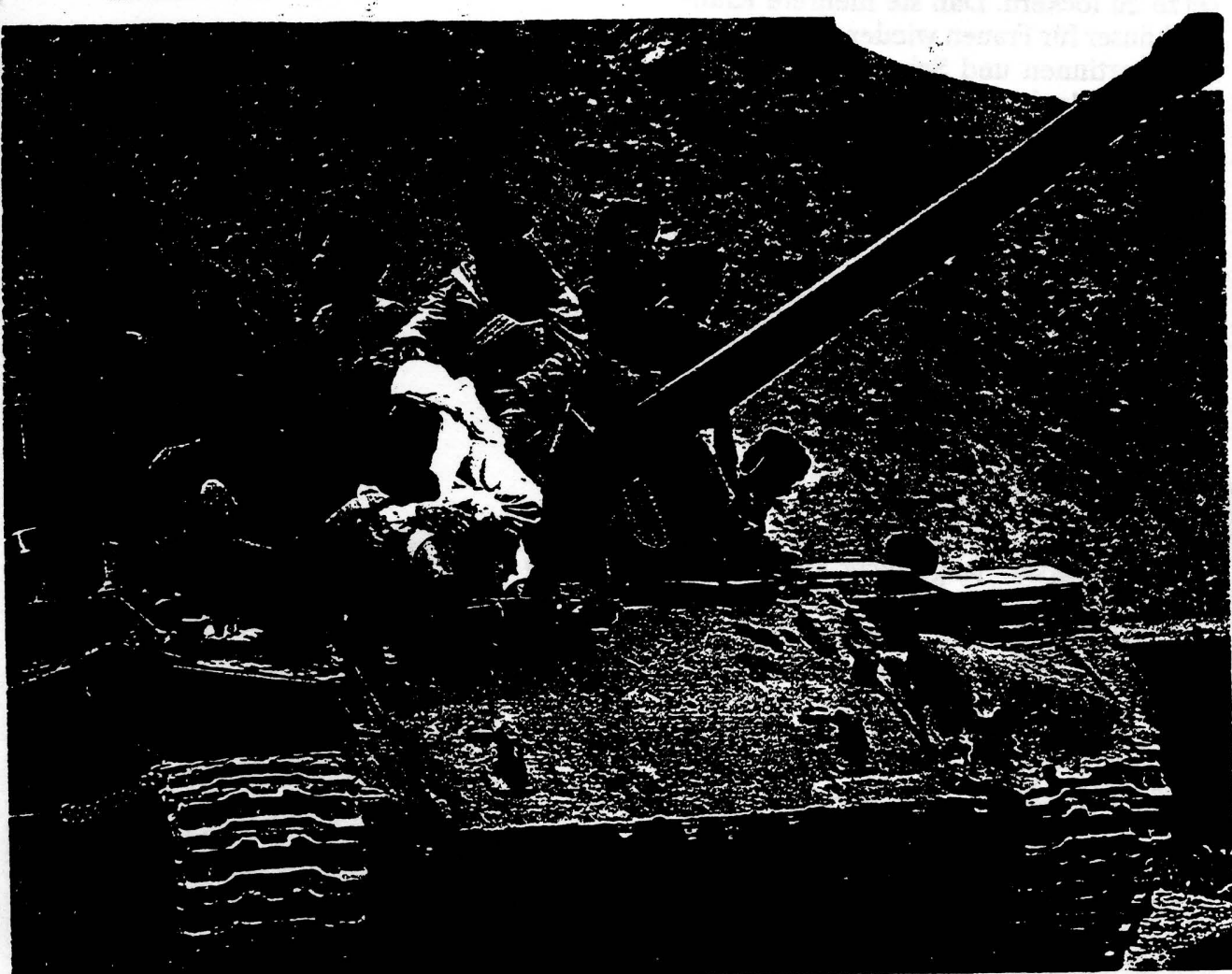

Taliban im Kampfgebiet: Angriff der Landbevölkerung auf die Großstädter

len, irgendwie aufbegehren, egal, wie sinnlos das sein mag. "Aber uns ist es ja noch nicht mal erlaubt, das Wort an einen Mann zu richten, der kein enger Verwandter ist", rechtfertigt sie ihr Schweigen von damals, und dann weicht sie dem Blick aus und sagt, wie sehr sie sich schäme.

Jamila fürchtet, Fehler zu machen, weil sie nicht begreift, nach welchem Recht die Taliban richten. Sie sieht nur deren Kalaschnikows. Viele ihrer Verbote stehen nicht im Koran. Die Frau des Propheten Mohammed arbeitete, sie aber werden am Arbeiten gehindert.

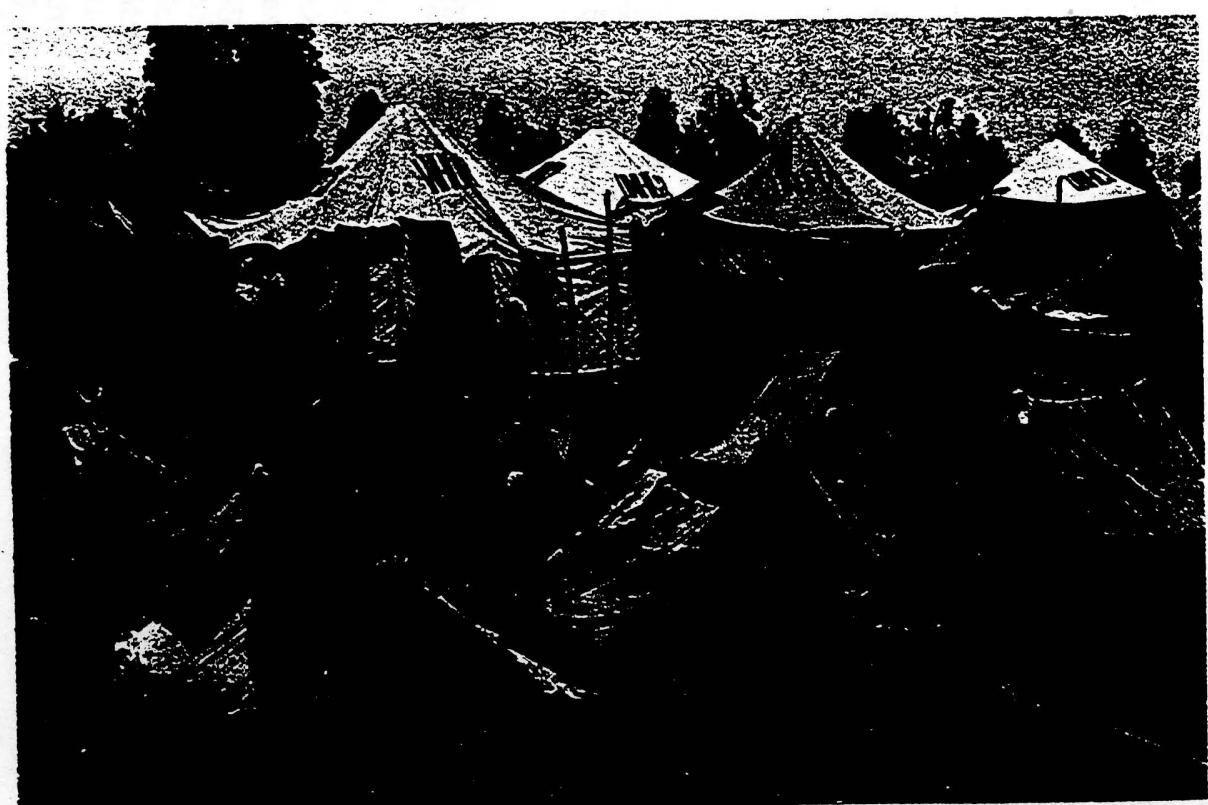

Füchttingslager Im pakistanischen Peschawar: Wer die Angst nicht länger aushält, flieht dion wieder zwei Dieben die rechte Hand amputiert. „Sie sind so sadistisch, daß man selbst mit Dieben Mitleid hat", sagt Jamila. Chirurgen standen vor mehr als $\mathbf{3 0 0 0 0}$ Zuschauern und trennten den Dieben unter Narkose mit dem Skalpell den Körperteil ab, mit dem sie gesündigt haben sollen. Im Namen Allahs, mit medizinischer Sorgfalt. Danach bekam eine vermeintliche Ehebrecherin 100 Peitschenhiebe.

Männer sind ebenso in Gefahr wie Frauen. Zwar können sie sich ein wenig freier bewegen, aber auch sie müssen ständig damit rechnen, beschuldigt $\mathrm{zu}$ werden; müssen fürchten, als schwul zu gelten und dafür lebendig begraben $\mathrm{zu}$ werden, zugeschaufelt mit Schlamm und Ziegelsteinen; müssen ihren Bart vorzeigen und es sich gefallen lassen, daß er von den Taliban als zu kurz beanstandet wird. Auch die Stirn muß frei bleiben, damit die Haare nicht den Gebetsteppich auf blasphemische Art berühren.

Erwischen die Taliban jemanden dabei, nicht $\mathrm{zu}$ den vorgeschriebenen Zeiten $\mathrm{zu}$ beten, dann schwärzen sie sein Gesicht und fahren ihn auf ihren Toyota-Geländewagen durch die Nachbarschaft. Ins Megafon brüllen sie: „Seht her! Dieser Mann ist ein schlechter Muslim. Er geht seinem Vergnügen nach, anstatt zu beten."

Selbst wenn sie nichts bei ihm finden, dann hat vielleicht seine Frau etwas falsch gemacht. Die Strafe fällt immer hart aus, denn er ist für sie verantwortlich. Jamila hat erlebt, wie ein Mann seine Ehefrau, deren Knöchel zu sehen waren, verleugnete; er kenne sie gar nicht, hat er dem Schlägerkommando zugerufen, und seine Stimme habe dabei gebebt. „Wie weit haben uns diese Analphabeten gebracht?" fragt Jamila, ,wir alle kuschen vor ihnen." Auch sie hat jeden Widerstand aufgegeben. Solange das Ausland nicht eingreife, glaubt sie, blieben sie dem Terror ausgeliefert. "Ich verstehe das nicht: Eine Frau hat sie doch auf die Welt gebracht", sagt sie, „respektieren die Taliban uns Frauen nicht, beleidigen sie auch ihre Mütter."

Wer die Angst und die Demütigungen nicht länger aushält, flieht. Zehntausende haben sich auf den Weg gemacht, über den Khyber-Paß zur pakistanischen Grenzstadt Peschawar, nach Tadschikistan oder Iran. Dort kommen sie bei Freunden unter oder in Auffanglagern, notfalls in Zelten, die sie sich aus zerrissenen Plastiktüten zusammenbauen. Sieben Millionen Afghanen sind in den vergangenen 18 Jahren vor Krieg und Hunger in die Nachbarstaaten geflüchtet. Mit den Intellektuellen, die flohen, verschwand auch die Opposition.

Einige von Jamilas alten Uni-Kollegen schieben Gemüsekarren durchs Viertel, nachdem all ihre Teppiche verkauft 
sind. Akademiker arbeiten als Maurer oder schicken ihre Kinder betteln. Die Mütter sind dazu verdammt, zu Hause zu sitzen und ihren Familien beim Hungern zuzuschauen.

Sie könne sich nicht erinnern, wann sie das letzte lachende Gesicht auf der Straße gesehen habe, sagt Jamila; jeder gehe nur noch mit einem klaren Ziel vor die Tür und kehre schnell wieder zurück. Besonders elend trifft es die 30000 Kriegswitwen, sie sammeln altes Brot und weichen es in Wasser ein, um irgend etwas zu essen zu haben. Die Taliban-Gesetze zwingen sie, zu Gesetzesbrecherinnen zu werden, wenn sie nicht verhungern wollen: Ohne männliche Begleitung dürfen sie nicht einen Joghurt kaufen. Es reicht schon, auf die Ware zu zeigen, um sich Ärger einzuhandeln - man kann für einen Moment den nackten Handrücken hervorlugen sehen.

Viele kommen nicht einmal so weit: Sie können keine 400000 Afghanis, rund 150 Mark, für die Burka aufbringen. Und selbst wenn, sie brauchen immer noch einen Mann, der ihnen das Gewand besorgt.

Nirgends gehen die Afghanische Landhochzeit Taliban so gnadenlos vor wie in Kabul, für niemanden ist der Sprung ins Mittelalter so gewaltig wie für die Gebildeten unter den Frauen in der Hauptstadt. Auf dem Land stehen Mütter und Töchter wie eh und je gemeinsam mit ihren Männern auf den Feldern, in der Burka wie all die Jahrzehnte zuvor. Sie arbeiten, sie feiern mit ihnen, und zu Hause treffen sie die Entscheidungen. Sie halten die Familie zusammen, sie verwalten das Geld. Keine käme auf die Idee, sich über die Fundamentalisten zu beschweren; die Taliban, sagen sie, sind noch das kleinste Übel. Schließlich haben alle, die vorher an der Macht waren, Schrecken gebracht. Die Taliban haben für sie die Aura heiliger Männer. Und nachdem sich zu Zeiten der Mudschahidin viele Frauen nicht getraut haben, allein das Haus zu verlassen, weil die Trupps des gestürzten Präsidenten Burhanuddin Rabbani kidnappten und vergewaltigten, sind die Straßen jetzt endlich sicher geworden.

Die Optimisten in Jamilas Verwandtschaft sagen, alles sei nur eine Frage der Zeit - die Taliban würden an ihrem Fanatismus ersticken. $\mathrm{Zu}$ viele ihrer Untertanen würden ihnen wegsterben oder ins Ausland verschwinden; ihnen bleibe bald keine andere Möglichkeit mehr, als die Ge- setze zu lockern. Daß sie mehrere Krankenhäuser für Frauen wieder eröffnet und den Ärztinnen und Schwestern das Behandeln erlaubt haben, sei ein erstes Zeichen dafür, daß sie die schleichende Selbstmordgefahr ihres Systems langsam einsehen.

Die Pessimisten glauben, daß das $\mathrm{Da}$ nach genauso schrecklich sein wird, wie das Davor war. Es werde nie besser. Den Krieg würden einfach andere weiterführen. Russen, Pakistaner, Araber, Iraner, sie alle seien bereit, den afghanischen Frieden zu opfern, zugunsten eigener Interessen.

Jamila hält das Leben wider die Vernunft wach. Sie kann schon lange nicht mehr schlafen. Dennoch sehnt sie sich bereits morgens nach der Nacht. "Ich hoffe schon beim Aufstehen, daß es bald dunkel wird."

Selbstmorde von Frauen kommen häufiger vor, viele wissen nicht, wie sie mit ihrer Ohnmacht leben sollen. Sie schneiden sich mit stumpfen Taschenmessern die Pulsadern auf oder vergiften sich mit Ätznatron - das ist nach wie vor zu bekommen.

Jamila wehrte sich gegen die Todessehnsucht, und doch erschien ihr jeder neue Tag mühsamer als der letzte. Sie hatte längst den $\mathrm{Spa}$ daran verloren, sich schönzumachen. Zu Hause trug sie nur ein Tuch und ihre ältesten Klamotten, wer sieht sie schon außer ihren Geschwistern . und ein paar Freunden? Eines ihrer Bücher zu lesen, kam ihr sinnlos vor; sie hat festgestellt, „daß man innerhalb der immergleichen Wände aufhört, neue Gedanken zu haben".

In solchen Momenten suchte sie sich in der Wohnung eine Ecke, in der sie heimlich weinen konnte. Und wenn die Anspannung ihre Hände flattern ließ, riß Jamila an ihren Fingerknöcheln, bis es schmerzte.

Am 1. Februar, einem Sonntag, beschloß Jamila, nicht länger auszuhalten. Gemeinsam mit ihrer Familie machte sie sich auf den Weg nach Peschawar.

200 Kilometer entfernt, im pakistanischen Camp Nasir Bagh, dürfen ihre Cousinen und sie sich wieder die Lippen pink malen. Sie hängen sich gegenseitig die einzige Burka um, die sie noch finden können, und kichern dabei wie kleine Mädchen. Und auch wenn sich Jamila aus Angst vor den Taliban immer noch nicht fotografieren lassen möchte, hier kommt ihr der Schleier nicht mehr unheimlich vor, nur noch albern.

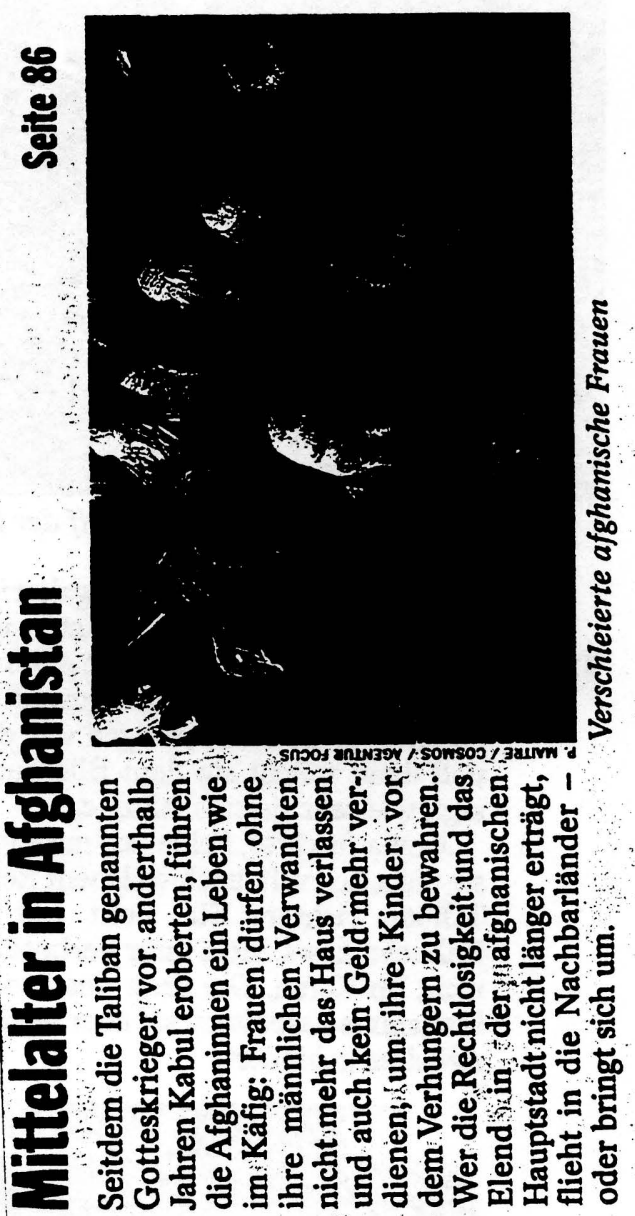




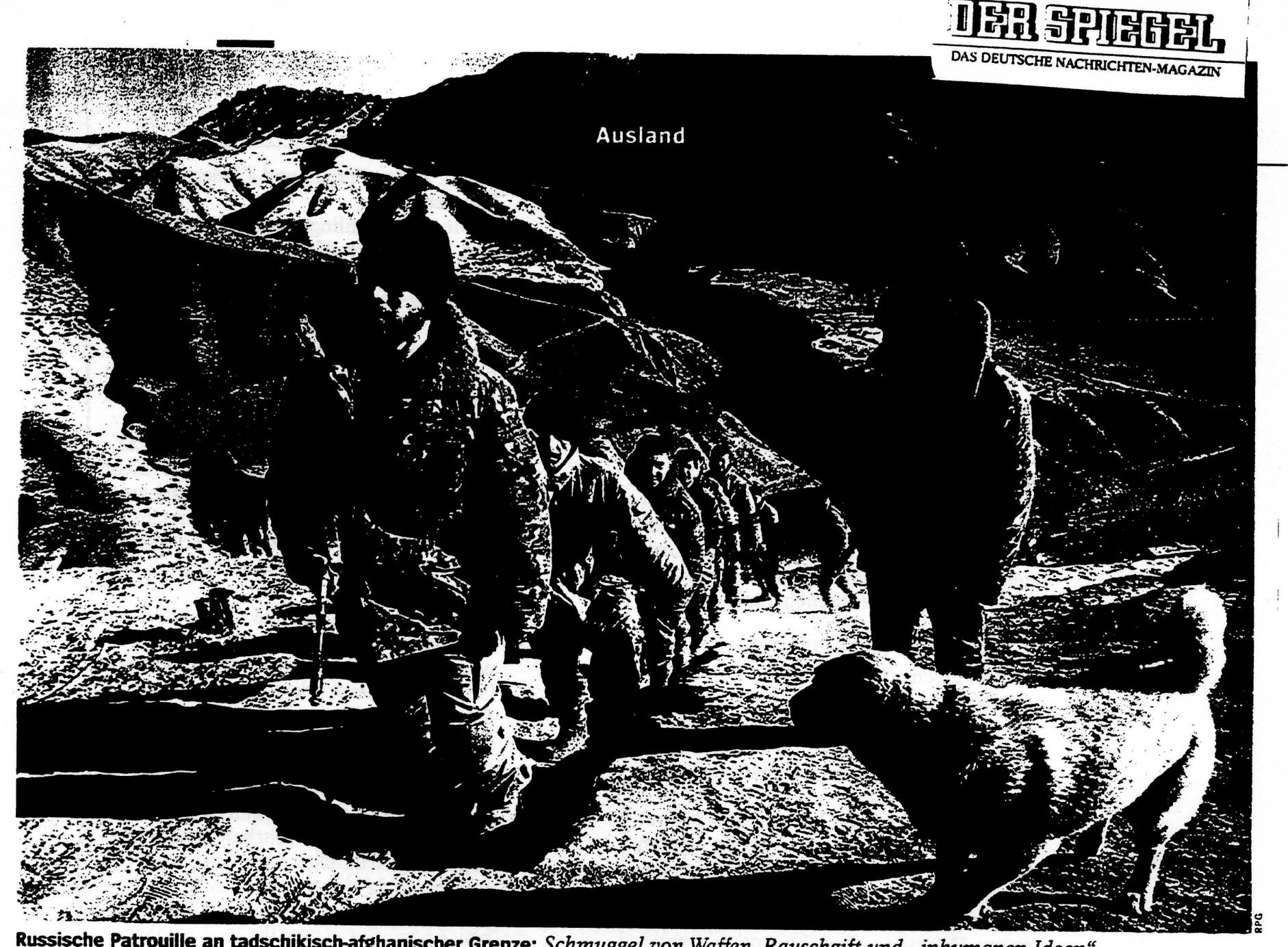

Russische Patrouille an tadschikisch-afghanischer Grenze: Schmuggel von Waffen, Rauschgift und „inhumanen Ideen“

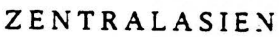 \\ "Tanzt doch endlich"}

Seit die fundamentalistischen Taliban Kabul erobert haben, geht an der Südflanke der ehemaligen Sowjetunion die Angst vor den Islamisten um: Die autoritären

Regierungen von Usbekistan und Tadschikistan schützen ihre Grenzen mit immer mehr Soldaten und Waffen - und mit Hilfe der Russen. Von Christian Neef

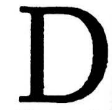
ieser Tag ist der Höhepunkt in der Karriere des Bahnwärters Rachmaschur. Der scharfe Afghan-Wind hat ihm die Haut wie mit Sandpapier abgeschmirgelt, denn schon seit sieben Jahren hält er Wacht auf der gottverlassenen Station Choschady in Tadschikistan nahe der afghanischen Grenze. Normalerweise steigt hier niemand aus oder ein, und nur ein-, zweimal pro Woche keucht ein Zug an dem weißgekalkten Wärterhäuschen vorbei.

Heute hat Rachmaschur Publikum. So viel. daß er immer wieder von neuem den Wüstenbahnsteig räumen lassen muß. 200 Tadschiken belagern den Schienenstrang. Vor Stunden sind sie aus ihren Dörfern in der Nähe der afghanischen Grenze angereist - um jenen Zug zu erwarten, der jetzt von Süden her über den gelben Horizont heraufkriecht.

Das eigenartige Gefährt, das sich schnaufend der Station nähert, hätte gut in die Pionierzeit der Transsibirischen Eisenbahn gepaßt: eine Lokomotive und vier verstaubte Passagierwaggons, denen ebenso viele offene Güterwagen mit bunter Fracht angekoppelt sind - schwere Gepäckballen, Mehlsäcke, Matratzen und Holzstämme, zwischendrin ein paar Kühe festgezurrt.

Für die über 300 Passagiere steht mitten in der Einöde ein Empfangskomitee der Provinzobrigkeit bereit. Der stellvertretende Bezirkschef Nasreddin Gulomchudarow schiebt zwei Frauen vor, die nach altem Brauch Brot und Salz überreichen sollen. Eine Zwei-Mann-Kapelle muß den Begrüßungstusch spielen - auf einer Trommel und einem Akkordeon, dem sechs Tasten fehlen.

„Tanzt, nun tanzt doch endlich“, fordert Rachmaschur seine Landsleute auf dem Bahnsteig auf, und weil keiner auf ihn hört, legt er schließlich selbst eine Art KosakenStepptanz auf den Betonschwellen hin.
Die Willkommensfreude ist inszeniert. Schlichte Neugier hat die meisten hergetrieben. Drinnen im Zug sitzen zwar Tadschiken. Doch es sind „Grüne“, Anhänger der islamischen Opposition, die im blutigen tadschikischen Bürgerkrieg vor gut fünf Jahren gegen die postkommunistische Zen-

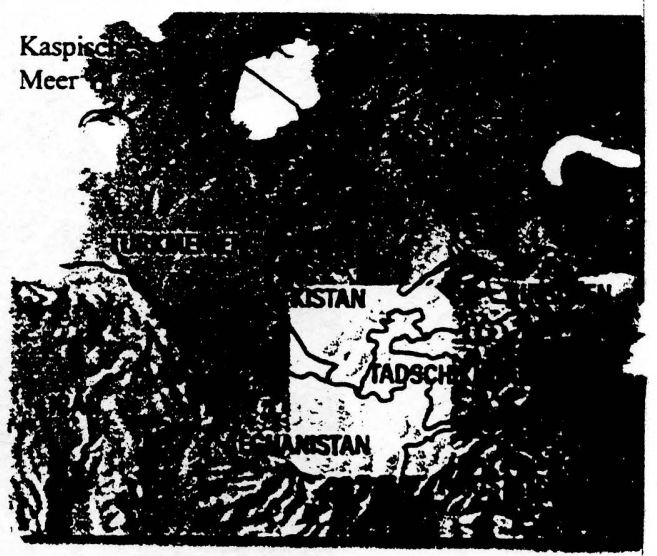


tralregierung kämpften, sich dann geschlagen nach Afghanistan retteten und nun zu Tausenden zurück ins Heimatland fluten. Seit die Gotteskrieger der Taliban das Nachbarland mit Waffengewalt unter die islamische Knute zwingen wollen, sind die Flüchtlingslager jenseits der Grenze nicht mehr sicher.

Tadschikistan, vom Zaren einst gewaltsam dem Russischen Reich einverleibt, von Stalin wirtschaftlich ausgebeutet und heute eines der 20 ärmsten Länder der Welt, übt Versöhnung mit den ehemaligen „Banditen". Gezwungenermaßen: Bisher hat sich die Pamir-Republik nicht von der grausamen Schlacht zwischen Roten und Grünen erholt, die - im Westen fast unbemerkt - bis zu 100000 Menschen das Leben gekostet hat.

Noch immer hat die Opposition mehrere Provinzen unter Kontrolle. Die Macht der Regierung reicht kaum über die Grenzen der gespenstisch wirkenden Hauptstadt Duschanbe hinaus, in der sich nach Einbruch der Dämmerung niemand mehr auf die Straße traut.

Präsident Emomali Rachmonow hat auf Druck Rußlands und der Uno im letzten Sommer der Bildung einer Koalitionsregierung mit den islamischen Widersachern und einer Rückkehr der verbliebenen 22000 Flüchtlinge aus Afghanistan zugestimmt.

Im Grenzort Choschady ist unübersehbar, daß die Heimkehrer als Fremde gelten: Die Männer haben lange Bärte, die Frauen sind in weiße Schleier gehüllt. Vorsorglich sind die Zugfenster mit Drahtgittern versperrt, jeweils drei Polizisten bewachen einen Waggonausgang, und auf dem Bahnsteig wimmelt es von Geheimdienstlern. Das Begrüßungslied („Schön, daß ihr in euer Land zurückgekommen seid“) wird von schrillen Anweisungen übertönt, die Wagen nur einzeln und geordnet zu ver-

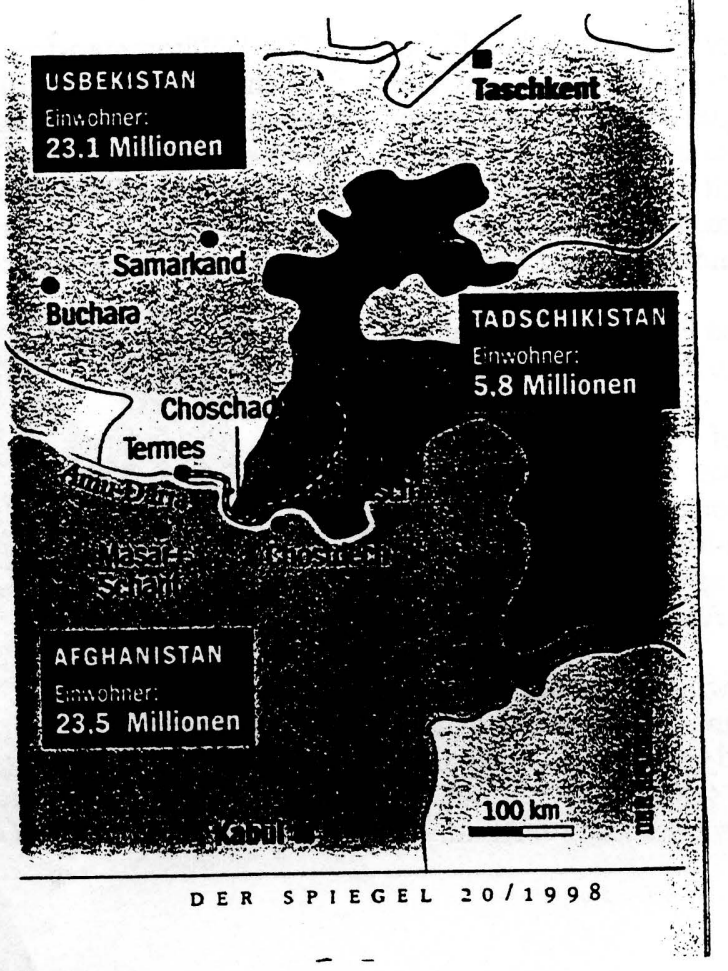

lassen. Zuerst Frauen und Kinder, dann die Männer.

Die Ankömmlinge werden von Polizisten gefilzt. Die Aktion soll Waffen oder Rauschgift zutage fördern, vor allem aber soll sie einschüchtern. Jeder Rückkehrer, so glauben die Beamten, sei ein militanter Botschafter Mohammeds, ausgesandt von den neuen afghanischen Machthabern, um die Lehre des Propheten nach Norden zu tragen.

Seit in Afghanistan fast überall die radikalen Koranschüler regieren, fürchtet nicht nur der Präsidenten-Clan in Duschanbe um seine Existenz. Aufregung herrscht im gesamten Süden der einstigen Sowjetunion - einem Gebiet elfmal so groß wie Deutschland.

Ein Grund dafür ist, daß die 54 Millionen Einwohner Zentralasiens zum ganz überwiegenden Teil Muslime sind und viele von ihnen sich unterdrückt fühlen. Ein anderer, daß Diktator Stalin einst die Grenzen in dieser Region auf dem Reißbrett quer durch ethnische Siedlungsgebiete zog und den Süden zum Baumwoll-Lieferanten degradierte. Seit dem Zusammenbruch des Sowjetreichs ist die Mehrheit der Landbevölkerung arbeitslos, der Rest wird seit Jahren nur in Naturalien bezahlt.

Vor allem die usbekischen Nachbarn haben Angst. Sie sehen ihr Ziel gefährdet,

\section{Panzersperren schützen die "Freundschaftsbrücke ${ }^{4}$ am Amu-Darja-Fluß}

neue Führungsmacht Zentralasiens zu werden, wenn der islamistische Funke über die Grenze springt.

Die Furcht vor dem militanten Islam teilen sie ìnit dem fernen Rußland, das seine muslimischen Gebiete an Wolga, Ural und Kaukasus gegen eine Offensive islamischer Ideen abschotten will - und deswegen selbst seit 1992 mit einer Streitmacht von 30000 Soldaten die gefährliche tadschikisch-afghanische Grenze bewacht. Im Mai 1997 verständigte sich Moskau mit Usbeken und Tadschiken, den Grenzwall nach Kräften aufzustocken.

Am usbekisch-afghanischen Übergang von Termes - dort, wo Alexander der Große den „Oxus", den Amu-Darja, überquerte - spannt sich jetzt eine große Stahlbrücke über den Strom. Sowjetische Propagandisten tauften sie einst "Freundschaftsbrücke", bevor Moskaus Truppen 1979 an dieser Stelle nach Afghanistan einmarschierten. Jetzt ist der ehemalige Checkpoint mit Panzersperren verstellt.

Die Taliban-Aktivisten haben gedroht, daß sie ihre Flagge bald auch in Usbekistan über den alten muslimischen Städten Buchara und Samarkand hissen würden. Deshalb sind die Ufer des schlammigen Flus: ses vermint. Bis weit ins Hinterland hat Usbekistans Präsident Islam Karimow 
Schützengräben ausheben lassen und die Wachposten mit Patrouillenhubschraubern, Panzern und Artillerie verstärkt.

Saidulo Naribinow, 37, gehört zu denen, die das waffengespickte Niemandsland auf halsbrecherische Weise überqueren mußten. Fünf Jahre hatte er mit Frau und sieben Kindern in einem Lager vor den Toren der nordafghanischen Stadt Masar-i-Scharif gehaust - dann kamen die Taliban: Das mit 7000 tadschikischen Flüchtlingen belegte Camp geriet unter Feuer, es gab Tote und Verwundete.

Das Flüchtlingshilfswerk UNHCR handelte schließlich mit Duschanbe die Rückkehr der Tadschiken über den nächstgele-

genen Grenzpunkt Termes aus. Doch die Usbeken sperrten sich gegen eine Brückenöffnung; wochenlang hatten sie selbst Uno-Leuten den Zugang zu deren eigenen Medikamenten- und Lebensmittellagern in der hermetisch abgeriegelten Grenzzone verwehrt. Erst massiver Druck der USA zwang sie zum.Einlenken.

Im Morgengrauen schickten sie Flöße über den Fluß, die die Flüchtlinge abholen sollten. „Der Amu-Darja führte Niedrigwasser, Allah sei Dank ‘s, sagt Naribinow. Die Flöße, überladen mit Mensch, Vieh und Gepäck, trieben zwischen den Sandbänken durch das lehmgelbe Wasser des Stroms. Die meisten konnten erst nach

mehreren Versuchen am anderen Ufer anlegen.

Die Angst vor den Nachbarn bekommt auch die islamische Opposition in Usbekistan zu spüren. Die in der Glasnost-Zeit auferstandene Partei der Islamischen Wiedergeburt ist verboten, ihre Anführer sind arschwunden. Zwei Drittel der in Gengnissen einsitzenden Usbeken, so schätzt ein westlicher Diplomat in Taschkent, sind Muslim-Aktivisten. Im tiefreligiösen Fergana-Tal brodelt trotzdem der Widerstand: „Krieger des Islam" brachten in den letzten Wochen ein halbes Dutzend Polizeioffiziere um - indem sie ihnen die Köpfe abschnitten.

„Extremistische Zentren“ in Pakistan und Afghanistan würden Millionen von Dollar in die Aufstellung einer fünften Kolonne investieren, klagte Karimow und rief zugleich 2000 usbekische Gaststudenten aus der Türkei zurück - um sie vor angeblich drohender Islamisierung zu retten. Sicherheitshalber schloß er die Grenzen zu Tadschikistan, weil er das Nachbarland wegen der Machtbeteiligung der islamischen Opposition für einen unsicheren Kandidaten hält.

Im Oktober schließlich ließ der Präsident mit großem Pomp den 2500. Gründungstag der Oasen-Städte Chiwa und Buchara feiern und sie zum Weltkultur- erbe erklären - um ihnen das Flair muslimischer Pilgerstätten zu nehmen.

„Usbekistan - ein Staat mit großer Zukunft" steht auf Transparenten, die sich über die Straßen der Hauptstadt spannen. Doch vorsorglich hat der Präsident seine 85000 Mann starken Truppen zur Kaderarmee aufrüsten lassen. Sie gilt inzwischen als eine der professionellsten in der GUS, nicht zuletzt dank deutscher Hilfe: 1996 lieferte die Bundeswehr für 26 Millionen Dollar Gerät, daheim bildet sie usbekische Panzerfahrer und Führungsoffiziere aus.

In Taschkenter Zeitungen sind die Themen Islam und Afghanistan tabu. „Keiner weiß, wie unsere Führung über die Lage in und um Kabul denkt", klagt ein Redakteur. Die Zensoren ließen nicht mal die Beteuerung der Taliban-Führung passieren, sie hätte "weder Kraft noch Wunsch", die islamische Ideologie nach Usbekistan oder Tadschikistan zu exportieren.

Die in Tadschikistan wachenden Russen haben einen entgegengesetzten Kurs eingeschlagen. Fast täglich melden sie Erfolge im Kampf gegen afghanische „Waffen- und Rauschgiftschmuggler"s - schon um zu rechtfertigen, daß die Regierung in Moskau eine ganze Armee am Pamir unterhält.

Nicht weit von der Bahnstation Choschady hat sich der Posten Nummer vier wie eine Wüstenfestung eingegraben -

\section{Das Abschneiden von Nasen und Ohren ist neuerdings verboten}

er ist nur per Jeep über einen steinigen Pfad zu erreichen, der über einen Bergpaß hinunter zum Grenzfluß führt. Die 40 Mann Besatzung haben sich hinter Munitionskisten, Wachturm und doppeltem Stacheldraht verschanzt. Vom anderen Ufer leuchtet friedlich und majestätisch das Rotgelb der afghanischen Berge. Totenstille.

Der Tadschike Scharif schiebt auf vorderstem Posten Dienst. Er hat sich als „Kontraktnik", als Berufssoldat, in der Einheit verdingt und schützt nun "die geopolitischen Interessen Rußlands“, wie sein Kommandeur aus Moskau erklärt.

Die Ruhe täuscht. Im letzten Jahr wurden hier mehr als 400 illegale Grenzübertritte gezählt, fast jeden Tag jagen MP-Salven über den Fluß. Je mehr sich die Taliban von Süden her nähern, um so intensiver wird der kleine Grenzverkehr. Bei einem der letzten Scharmützel Ende April haben die Soldaten fünf Afghanen erschossen, die nach Tadschikistan hineinwollten. Sie hatten reichlich Granaten und Maschinenpistolen, in Afghanistan gedruckte Propagandabroschüren der tadschikischen Opposition und vier Säcke Rohopium dabei.

Wenn es stimmt, daß Rauschgift als wichtigstes Zahlungsmittel im Glaubenskrieg gilt, steht eine Frühjahrsoffensive der Islamisten bevor. Bei Posten Nummer elf 


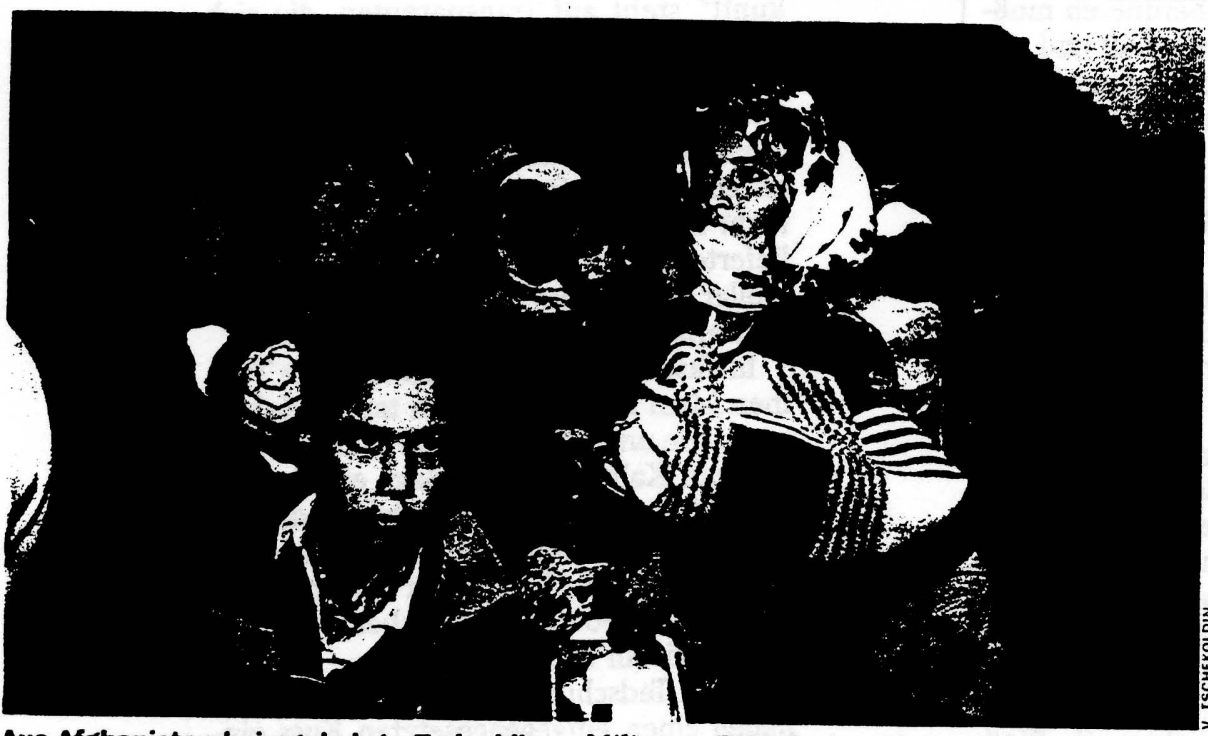

Aus Afghanistan heimgekehrte Tadschiken: Militante Botschafter Mohammeds?
Zwischen den verrußten Lehmwänden hat Feiseddin seine Habe gestapelt: 25 Quadratmeter Kunststoffplane als Regenschutz, gestiftet von der UNHCR, sechs Säcke mit amerikanischem Mehl und einen Kanister Rapsöl, eine Spende aus Finnland.

Die Leute von der Schweizer Caritas, die draußen die Mauerreste prüfen, haben ihm Hoffnung auf ein neues Dach gemacht. Unterstützt vom European Community Humanitarian Office und dem Diakonischen Werk betreiben sie unter Leitung des Deutschen Lutz Leichtfuß drei Ziegeleien, in denen 170 Tadschiken einfache Dachziegel produzieren - ohne ausländische Hilfe wäre das Land längst am Ende.

Feiseddin will sein Haus bis zum Sommer fertig haben; unter dem stehengebliebenen Granatapfelbaum hat er Weizen gesät. Doch im Innersten ist er skeptisch. Die Dorfbewohner haben alles geraubt, was er in der Hochzeitskiste im

beschlagnahmten die Grenzer dieser Tage 53 Kilogramm reines Heroin im Wert von neun Millionen Dollar - ihr bislang größter Fund.

Einen „undurchdringlichen Schutzwall“ gegen den Schmuggel von Waffen, Rauschgift und ,inhumanen Ideen“ zu errichten, lautet der Kampfauftrag. Doch die meisten illegalen Grenzgänger bleiben in dem zerklüfteten Gelände unentdeckt. „Vielleicht auch besser so", tröstet sich Scharif. Er will nicht für Rußland fallen wie die 25 Mann von Grenzposten Nummer zwölf, die vor viereinhalb Jahren von Afghanen niedergemäht wurden.

Von jenen, die den Titel „Held Rußlands" bekamen, hat jeder zweite an der tadschikisch-afghanischen Grenze gedient - und fast alle wurden erst postum mit der höchsten Moskauer Auszeichnung geehrt. Erst jüngst fielen in Scharifs Nachbareinheit zwei Hauptleute, obwohl die $1200 \mathrm{Ki}$ lometer lange Demarkationslinie inzwischen für umgerechnet rund eine halbe Milliarde Mark zur Hochsicherheitszone ausgebaut wird.

Trotzdem gilt der Grenzdienst wegen der guten Bezahlung vor allem für Offiziere als lukrativ. Nicht wenige mischen offenbar selbst im Rauschgift-Business mit. Merkwürdig nämlich: Keine einzige Tonne der voriges Jahr beschlagnahmten Menge Rohopium ist öffentlich vernichtet worden. Ein Gericht in Duschanbe verurteilte jüngst einen Pakistaner wegen Schmuggels von 500 Gramm Heroin - genau jene Menge, die für 20 Jahre Gefängnis reicht. In Wirklichkeit hatten die Grenzer den Mann mit drei Kilogramm erwischt, der Rest war verschwunden.

Anders auch seien die vielen Morde an russischen Militärs in Duschanbe kaum erklärbar - „schlichtweg Abrechnungen in der Rauschgiftszene", sagt ein Diplomat in Duschanbe. Aus Angst vor Entführungen hat der Armeestab die Kinder der Grenzer inzwischen in einer von Soldaten streng

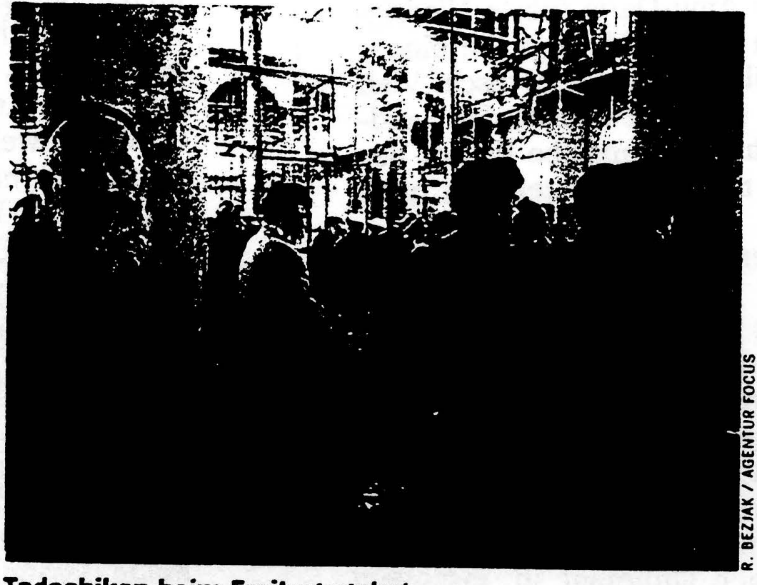

Tadschiken beim Freitagsgebet

"Frieden im Herzen "

bewachten Schule am hauptstädtischen $\mathrm{Ru}$ daki-Boulevard kaserniert; selbst die Lehrer werden mit Panzerwagen nach Hause eskortiert.

Wer Freund ist oder Feind, das vermag Scharif nicht zu klären. Schon die 7000 tadschikischen Flüchtlinge, die nebenan in Nischni Pjandsch aus Afghanistan zurückkehrten, mußten die Grenzer widerwillig passieren lassen - obwohl ihre Kommandeure im Politunterricht noch immer von ,auszurottenden Banditen“ reden. Seit Februar warten auf der afghanischen Seite sogar über 500 Kämpfer der islamischen Oppositionstruppen auf Einlaß - laut Friedensabkommen dürfen selbst sie in den nächsten Tagen in die Heimat zurück.

Auch Feiseddin Soim, 43, ist über Nischni Pjandsch heimgekommen, mit „Frieden im Herzen“, wie er beteuert - ins Dorf Bolschewik, wo er 20 Jahre als Dreher arbeitete und ein Drei-Zimmer-Haus baute. Von dem stehen nur noch die Grundmauern, keines der Bolschewik-Häuser blieb unzerstört. Während seine Nachbarn - Safaralik, der Traktorist, und Muralik, der Chauffeur - noch auf der anderen Seite sind, versucht er den Wiederaufbau.
Garten vergraben hatte. Jetzt klauen sie nachts die Kühe, die Flüchtlinge aus Afghanistan mitbrachten.

Feiseddin stammt wie viele hier aus der Region Garm, östlich der Hauptstadt. Die Leute von Garm sind fromm und fleißig. Sie wurden vor $50 \mathrm{Jah}$ ren von Stalin hierher umgesiedelt. „Für uns krümmen die Behörden keinen Finger, weil wir aus dem Lager von Kundus kommen", sagt Feiseddin. Das ist ein Camp, das in Duschanbe als Ausbildungslager für muslimische Terroristen gilt. Die Taliban seien strenge Leute, ,aber Kundus Wegelagerei und Korruption abgeschafft".

$\mathrm{DaB}$ zumindest in einigen Regionen Tadschikistans ein Taliban-ähnliches Regime Fuß greifen wird, ist für Intellektuelle in Duschanbe fast ausgemachte Sache. Die Russin Galina Iwanowna glaubi nicht an den Frieden, „weil jeder Provinzboß seine eigene Armee unterhält - uns erwartet auf jeden Fall das Schicksal Afghanistans".

Gerd Merrem, 59, Uno-Sonderbeauftragter für Tadschikistan, hat im Dezember 1996 auf der Bergfeste Chostdech im nordafghanischen Pandschir-Tal den Frieden zwischen dem tadschikischen Präsidenten Rachmonow und Oppositionsführer Said Nuri zustandegebracht. Doch er weiß, wie brüchig die Abmachung ist. Nuri hat wenig Einfluß auf die Hardliner im eigenen Lager. Fast täglich erschüttern Terroranschläge Tadschikistan; erst vorletzte Woche kàmen bei schweren Gefechten mindestens 30 Menschen ums Leben.

Ansätze zur Trendwende sind aber unübersehbar. Nuri hat Anweisung gegeben, gefangenen Gegnern nicht mehr Nasen und Ohren abzuschneiden. sie haben immerhin rund um 


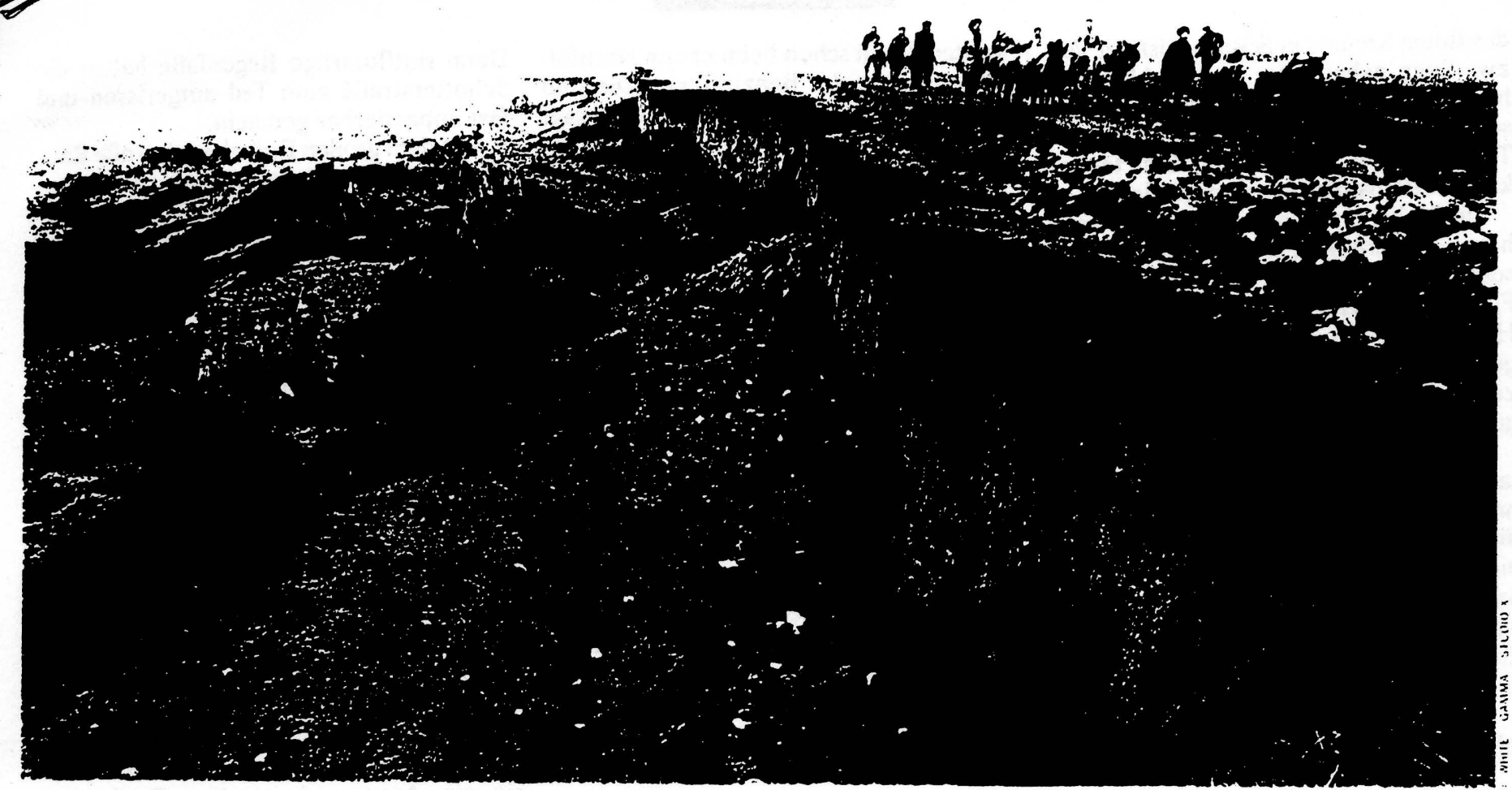

Katastrophengebiet an der afghanisch-tadschikischen Grenze: „Das ist ein Alptraum hier“

AFGHANISTAN

\section{„Dann begann der Berg zu qualmen“}

Mit kümmerlichen Mitteln versuchen Hilfstrupps der Uno und des

Internationalen Roten Kreuzes, im Erdbebengebiet am Hindukusch die Folgen der Katastrophe zu lindern, die 5000 Menschen das Leben gekostet hat. Von Reinhard Krumm

$\mathrm{D}$ as schlammverschmierte Gesicht der kleinen Bibiko ist wie versteinert. Dabci hätte sic allen Grund, laut aufzuschreien. Denn Dr. Saijed Habib ist dabei, ihr zwei kirschkerngroße Eiterblasen mit sterilen Pinzetten zu öffnen. Nachdem er den von Blut und Jod tropfenden rechten Handballen verbunden hat, gibt er einem der beistehenden vollbärtigen Männer aus dem Bergdorf Robat-iGardan rasch drei Antibiotikum-Ampullen. ein paar Spritzen, Nadeln und Mullbinden. Die Nachbehandlung müssen sie selbst übernehmen.

Dem Doktor laufen in der prallen Sonne Schweißbäche am Körper hinab. Im Hintergrund rauschen die Rotorblätter des russischen Mi-8-Hubschraubers, der auf einem schlammigen Plateau in über 2000 Meter Höhe hin- und herrutscht. Zwei Helfer des Roten Kreuzes und der Vereinten Nationen haben derweil mit Hilfe der örtlichen Bevölkerung 41 Sack Getreide, 8 Kartons Speiscöl und 50 Decken abgeladen. Nach zehn Minuten steigt der Hubschrauber knatternd wieder auf und fliegt das dreiköpfige Team zum nächsten Einsatzort.

Das Dorf Robat-i-Gardan liegt nur vier Kilometer vom Epizentrum des Erdbebens entfernt, das die nordafghanischen Provinzen Badakhshan und Takhar erschüttert hat. Erst aus der Luft wird das ganze Ausmaß der Katastrophe deutlich: Lehmunterkünfte sind wie Kartenhäuser zusammengestürzt und zum Teil mit den tragenden Holzstämmen den Abhang hinabgerutscht. an den das Dorf terrassenförmig gebaut war. Nur 25 Familien überlcbten. Sic schlafen nun aus Furcht vor weiteren Beben auf bunten Decken unter freiem Himmel.

Um Nahrungsmittel und Zelte ins Katastrophengebiet zu bringen, fliegen jeden Tag - soweit es das unbeständige Wetter zuläßt - Helikopter aus der gut 200 Kilometer entfernten Nachbarrepublik Tadschikistan die nördliche Provinzstadt Feisabad an. Außerdem landen stündlich wciße MiniTransportflugzeuge der Uno und des Internationalen Roten Kreuzes aus Pakistan und afghanische Antonow-Militärmaschinen aus Masar-i-Scharif.

Den Landeplatz hat die sowjetische Armee nach ihrem Einmarsch vor fast 19 Jah- ren gebaut. Noch immer säumen ausgeschlachtete rostige Schützenpanzer die 1700 Meter lange und 40 Meter breite Rollbahn, die Pioniere aus grün angemalten Metallplatten damals zusammenschraubten. Um Bruchstellen rechtzeitig zu erkennen, preschen jeden Morgen Gelände-

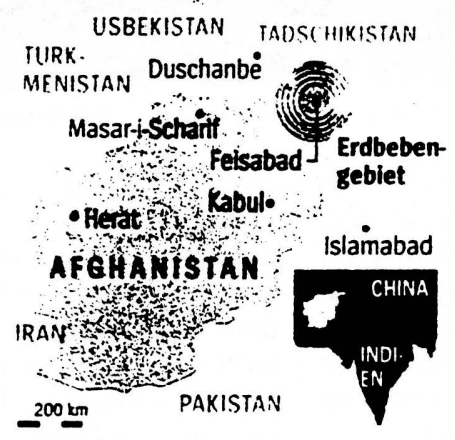
wagen mit Vollgas über sie hinweg. Ein paar Mcter neben der Piste weht eine rote Flagge. Das bedeutet: Achtung. erhöhte Minengefahr.

Damit es bei dem zunehmenden Flugverkehr nicht zu Kollisionen in der Luft kommt. flog dic Uno vor einer Woche eine Gruppe von fünf holländischen ...Airops" ein. Das sind speziell auf improvisierte Sondereinsätze gedrillte Fluglotsen, die ein Minimum an Sicherheit gewährleisten sollen.

Der Landweg ist unpassierbar, denn Lastwagen und Esel bleiben im Schlamm stecken, weil in diesem Fruhling die Schneeschmelze so spät eingesetzt hat.

Svante Yngrot, der braungebrannte und kräftig gebaute schwedische Koordinator 
des Roten Kreuzes in Feisabad, ist der Verzweiflung nahe: „Das ist ein Alptraum hier." Medikamente und Nahrungsmittel seien ausreichend vorhanden, nur kein Transportgerät. Mehr als zehn Orte täglich kann er deshalb nicht versorgen lassen.

Die Helfer von Uno und Rotem Kreuz haben Regierungen, private Anbieter und sogar die Nato um die Bereitstellung von Fluggerät gebeten. Als dann endlich ein Hubschrauber aus Sri Lanka nach Pakistan gebracht worden war, streikte die Besatzung. weil ihr der Afghanistan-Auftrag zu gefährlich war.

Selbst die Sprache macht Probleme. Das tadschikische Flugpersonal spricht Russisch und nur wenig Englisch. Oftmals können die Piloten in Not geratene Ortschaften nicht ausfindig machen, denn ihr Kartenmaterial stammt noch aus der Sowjetzeit. während Uno-Karten englische Transkriptionen benutzen. die dic Crews nicht lesen kïnnen.

Tabib, seit 23 Jahren im Cockpit, ist hier schon für die Sowjets Einsätze geflogen.

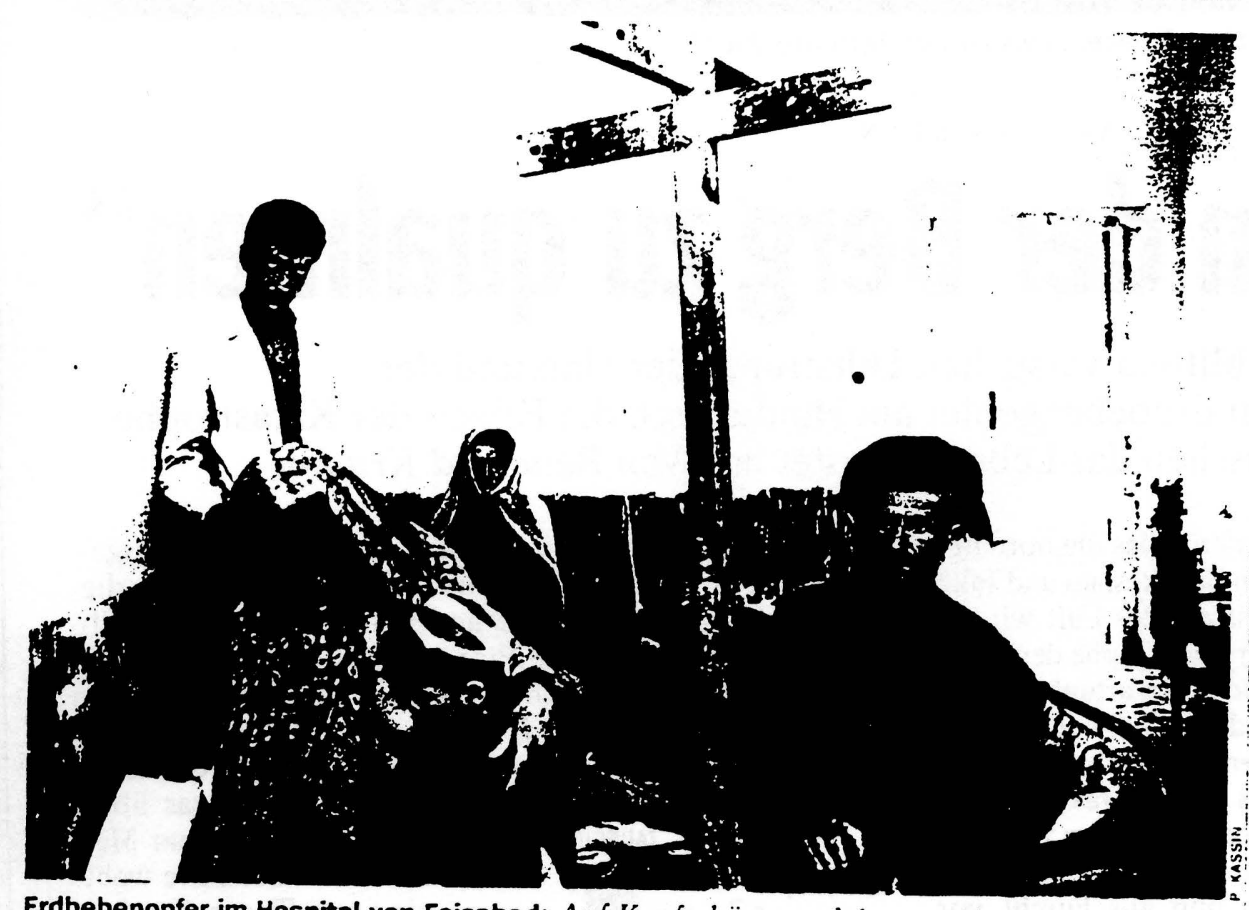

Erdbebenopfer im Hospital von Feisabad: Auf Kopfschüsse und Ampututionen spezialisiert
Sobald er mit seinem orangefarbenen ..Heli" am frühen Morgen über die Gedem Flugfeld glcichzeitig freudig und gereizt. Denn er steht den Hilfsorganisationen immer nur für wenige Stunden zur Verfügung und kehrt am frühen Nachmittag wieder nach Duschanbe zurück.

Der Grund: Die Piloten haben nur 3600 Liter Treibstoff, gerade genug für An- und Abflug sowic zwei Flugstunden im Einsatzgebiet. Und Auftanken ist nur in Duschanbe erlaubt, denn das Kerosin in Feisabad taugt nicht viel.

Dabei sind aus Peschawar extra Fässer in die tadschikische Hauptstadt geflogen. dort abgefüllt und dann nach Feisabad gebracht birgsketten einfliegt, ist die Stimmung auf

worden. Doch schon beim ersten Nachfüllen verstopfte der Benzinfilter. „Die sind mächtig übers Ohr gehauen worden", sagt Tabib.

Davon ist auch der Sprecher der Vereinten Nationen, Rupert Colville, überzeugt, der sich neben dem Rollfeld einen grünen Tee genehmigt: ,Sobald wir irgendwo aufkreuzen, schießen die Preise in die Höhe. "In Afghanistan, wo fast die gesamte Infrastruktur zusammengebrochen ist, fühle er sich wie ein Astronaut im Weltall. ,Man ist von allem abgeschnitten."

In Schorak, dem zweiten Dorf, das Habib von Feisabad aus anfliegt, ist ein Teil der hellbraunen Lehmhäuser einen Hang hinabgestürzt. Kaum ist der Hubschrauber dicht neben einem ausgetrockneten Flußbett gelandet, nimmt Uno-Mitarbeiter Abdul Amiki die Verlustmeldungen auf, die der Dorfälteste zusammengestellt hat: 43 Menschen sind tot, 30 verletzt, 20 werden noch vermißt.

Habib ist ein alter Routinier. Seit über zehn Jahren arbeitet er für den Roten gionen der Welt. Bei jedem Einsatz springt der kleine Mann mit den vielen Lachfalten um dic Augen behende als crster aus dem Hubschrauber. Der 43jährige ist verantwortlicher Arzt für die gesamte nördliche Berg-Region. Die gehört zu den 20 Prozent des Landes, die die in Kabul regierenden Taliban noch nicht besetzen konnten.

Besonders schwere Fälle hat der Doktor während der vergangenen Tage in das staatliche Krankenhaus in Feisabad eingeliefert. Obwohl die Klinik vom Flughafen nur sechs Kilometer entfernt ist, benötigen sogar die Geländewagen der Hilfsorganisationen über eine dreiviertel Stunde.
Halbmond hier in einer der ärmsten Re-
Denn sintflutartige Regenfälle haben die Schotterstraße zum Teil aufgerissen und fast unpassierbar gemacht.

Seit dem großen Erdbeben sind alle Räume im Hospital belegt, sogar die Ärztezimmer, wo in Regalen noch immer zerfledderte Medizinbücher in russischer Sprache stehen. Überall wimmelt es von Fliegen, der Geruch von Desinfektionsmittel bohrt sich stechend in die Nase.

Alle reden nur über das Erdbeben. „Wir hörten ein fürchterliches Geräusch“. berichtet der 20jährige Dschuma Chan. "dann begann der Berg zu qualmen, er sackte ab und begrub unser Dorf." Seine Mutter Sinat hielt sich im Haus auf, als die Erde bebte. Das herabstürzende Dach brach ihr das rechte Bein. Seitdem schläft Chan auf dem staubigen Steinfußboden vor ihrem verrosteten und durchgelegenen Bett. Ob sie die Überlebenden ihre's Dorfes wiederfinden? Inschallah, wenn Gott will.

Im Nebenzimmer liegt die sechṣährige Malicha. Sie stöhnt vor Schmerzen, weil sie ein Auge verloren hat. Doch das Schlimmste steht ihr noch bevor: Bislang hat keiner gewagt, ihr zu sagen, daß ihr Vater und ihre Mutter tot sind.

Abdul Satar, der seit über zehn Jahren Krankenpfleger ist, sieht das Elend hier eher gelassen. ,Wir haben schon ganz andere Fälle behandelt: Kopfschüsse und Amputationen." Und erklärend fügt er hinzu: „Der Bürgerkrieg ist unser bester Lehrmeister."

Im Vergleich zu dem Beben, von dem Afghanistan im Februar getroffen wurde, gab es diesmal weniger Verletzte und mehr Tote - insgesamt 5000 Menschen. Da die Katastrophe am Vormittag geschah, sind dic meisten Opfer Frauen und Kinder. Dic Männer arbeiteten zum Zeitpunkt des Unglücks auf den Feldern.

Viele Quellen sind verschüttet, das Vieh ist verendet. Alle haben Angst vor Epidemien. Nicht auszudenken. wenn jetzt zu allem Übel auch noch die Cholera ausbrächc.

Unklar ist noch, wie viele der zerstörten Lehmhütten wiederaufgebaut werden können. Die Uno plant nun. Wohnkahinen einzufliegen, deren Wände bei erneuten Beben nach außen klappen.

Bis Ende Juni wird Habib noch in Feisabad dic Stellung halten. Wenn es seine Zeit erlaubt, wird er auch künftig ab und an auf einen Drink und einen Plausch bei dem stellungslosen Geographielehrer Machmut Fosil vorbeischauen, der seit über einer Woche vor dem Flughafengelände in $\mathrm{Abu}$ Dhabi produzierte Orangenlimonade feilbictet. Lehrer Fosil verkauft die Dose für 68000 Afghani, auf dem Schwarzmarkt ungerechnet ein US-Dollar. Das sei sehr moderat, sagt er. „Nach dem nächsten Erdbeben werde ich wohl den Preis erhöhen müssen." 


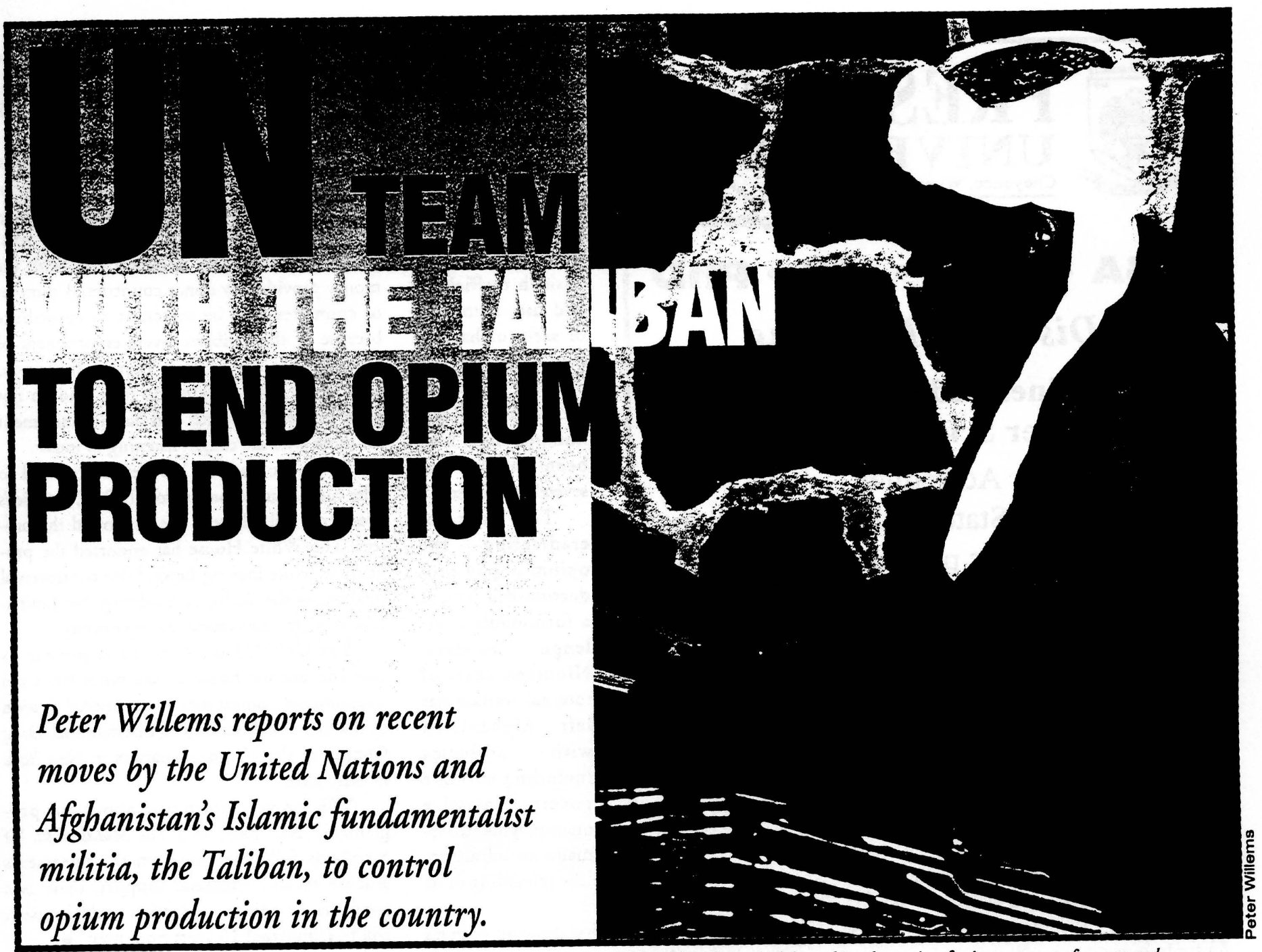

The Taliban militia which has achieved notoriety for its treatment of women and severe punishment of those accused of un-Islamic acts has made concessions

( llegal drug use is among the worst scourges facing 20th century society and, according to the experts, unless the problem is tackled head on the spread of illicit drugs will lead to increased levels of crime and misery on the streets of towns and cities across the world. However, drugs running is a highly lucrative business and the so-called "international drugs barons" are always on the look out for new, cheaper sources of supply.

Some 40 per cent of the raw opium which finds its way to international markets is produced in Afghanistan. In addicion to its obvious implications in combating the spread of drugs, the latest move by the Taliban is being interpreted as a further step towards the organisation achieving recognition as the legitimate governing body of Afghanistan.

The United Nations International Drug Control Programme (UNDCP) has taken its first steps to assist the Taliban militia to eradicate opium production in the areas of Afghanistan under Taliban control. It is an aim the fundamentalist political group must prove itself anxious to achieve, if it is to attain the international recognition it craves.

\section{The programme would include} helping to rebuild the country's

\section{war-battered infrastructure}

There is no doubt the Taliban has made huge financial gain from the opium industry, with funds taken from local growers in the form of taxes. In the past Taliban officials claimed it would be inhuman to crack down on poppy growing without providing the farmers with an alternative source of income. Now, with UN help, the dilemma might be solved.

"If the Taliban can prove they are willing to enforce a ban on production, trafficking and consumption of opium, we are willing to help rebuild the infrastructure to assist the people in Afghanistan improve their income through other agricultural products," said Sindro Tuchi, spokesman for the UNDCP at the international centre in Vienna, Austria.

According to UNDCP, 40 per cent of raw opium on the international drug marker is produced in Afghanistan - approximately 2,300 metric tons per year - which rivals Burma as the world's leading producer. Some 96 per cent of this total is produced in Taliban-held areas of the country.

The first step of the UN-backed project the Taliban has agreed to follow aims at building trust. If the Taliban will put a lid on opium output, to keep the amount produced in 1998 equal to that of 1997 , LNDCP will re-establish a wool factory in Qandahar, one of the largest cities in the southern region, which is the Taliban's stronghold. The factory will employ 1,200 Afghanis, 20 per cent of whom will be women.

The Taliban militia, which has been notorious for not allowing women to work or go to school since taking control of 75 per cent of the country, has agreed to let women work in 


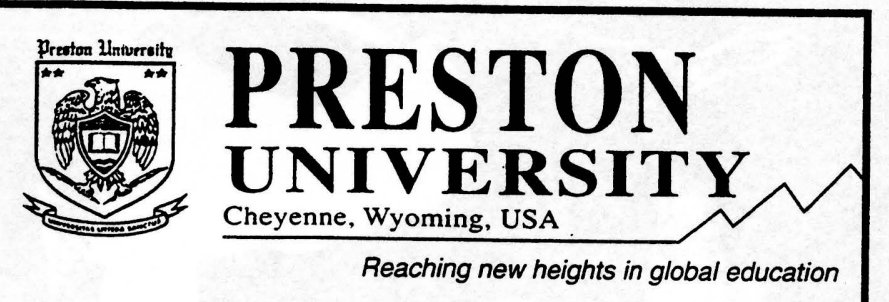

BBA - MBA - MS - PhD

Distance Learning

\section{Business Administration \\ Computer Science • Education}

Accredited

Licensed by State Dept. of Education

Also on-campus programs available at

Cheyenne campus in USA and at

\section{2 affiliated centers worldwide}

Preston University, Dept. ME498

1204 Airport Parkway • Cheyenne, WY $82001 \cdot$ USA

Tel: + 1 (307) 634 1440 • Fax: + 1 (307) 6343091

Email: admissions@preston.edu •www.preston.edu stop opium production in our country."

The Taliban party officially condemned the use of illicit drugs in 1996 and has since launched an aggressive attack on hashish trafficking and use. Hundreds of sacks of hashish have been seized and burned in open fields and several hundred users have been caught and severely punished.

The task of eradicating the opium poppy production will present a formidable challenge, however. Nineteen years of internal warfare has left Afghanistan with problems including extreme poverty, massive unemployment, virtually no infrastruc-

the new factory as long as they operate separately from men. UNDCP will also rebuild a redistribution substation to provide electricity for the factory.

If UNDCP officials see the Taliban keeping their word on controlling opium output, the UN will re-endorse the project and make plans to broaden a programme it hopes will extend for 10 years, focusing on assisting poppy farmers to switch to other suitable crops. The programme would include helping to rebuild the country's war-battered infrastructure, starting up previously run businesses, re-establishing irrigation systems and providing equipment and the necessary machinery for alternative crops to be established in Taliban-controlled areas. Mr. Tuchi stressed that funds required for the project would be tightly controlled to make sure they reached only UN agencies and contractors carrying out UN approved projects.

There have been questions as to whether the Taliban are serious about the plan to eradicate opium production since it has earned them huge amounts of money, subsequently used to support their war effort. The governor of the Qandahar province, Mullari Muhammad Hassan, explained: "Since we first started our movement in Afghanistan, we believed the production of an illicit drug was against Islamic Law and therefore wrong. We would like to ture and little real hope for the rebuilding of its economy.

Farmers have found that growing poppies is the only way they can make a decent living. Land turned over to poppy cultivation can make as much as five times the amount earned by other crops. In some areas, such as the Helmand province which accounts for 57 per cent of opium output, new houses are going up rapidly, daily meals are enjoyed by most families and new clothes and shoes for children are no longer a luxury.

However, this recently acquired affluence could present the Taliban with a problem if it attempts to stamp out poppy production: a possible rebellion among farmers and traffickers. A number of farmers and sharecroppers in areas where poppies flourish have already spoken out, saying that because of the loss of income, they would not tolerate an immediate eradication of opium.

The governor of the $\mathrm{Q}$ andahar province says the Taliban is well aware of the plight of the farmers: "We would like to end opium production, but we have two problems. Firstly, the poppies. If we enforce a ban immediarely, they will have no way to support themselves. Secondly, in order for them to switch to a more appropriate crop, they need equipment, seeds only way people can make money is to grow and better roads to transport their produce to points of sale. With help from the UN we might be able to change what they grow. But it will take time."

If the Taliban militia proves willing to assist in ending Afghanistan's flourishing opium production, the UNDCP will be taking on a huge financial commitment. The 10 -year programme will cost $\$ 25$ million a year, with the money provided by donor countries. A number of countries may be reluctant to contribute because of the Taliban's severe enforcement of strict Islamic law, such as beating those who miss prayer time, locking up men who do not grow full length beards and harsh punishment for those who are caught listening to music.

So far, no country has stepped forward to offer funds but, according to UNDCP, America's President, Bill Clinton, has supported the project. The White House has endorsed the programme while looking beyond the controversial methods of the Taliban, considering the elimination of poppy cultivation the top priority.

The UNDCP is scheduled to present its case and ask for financial assistance from the international community at the Special Session of the General Assembly of International Drug Control at the UN headquarters in New York in early June.

"We are very optimistic about our programme," Mr. Tuchi told The Middle East. "If everybody follows through on the agreements and we receive financial support, there is a good chance opium production in Afghanistan will be eliminated 10 years from now." -

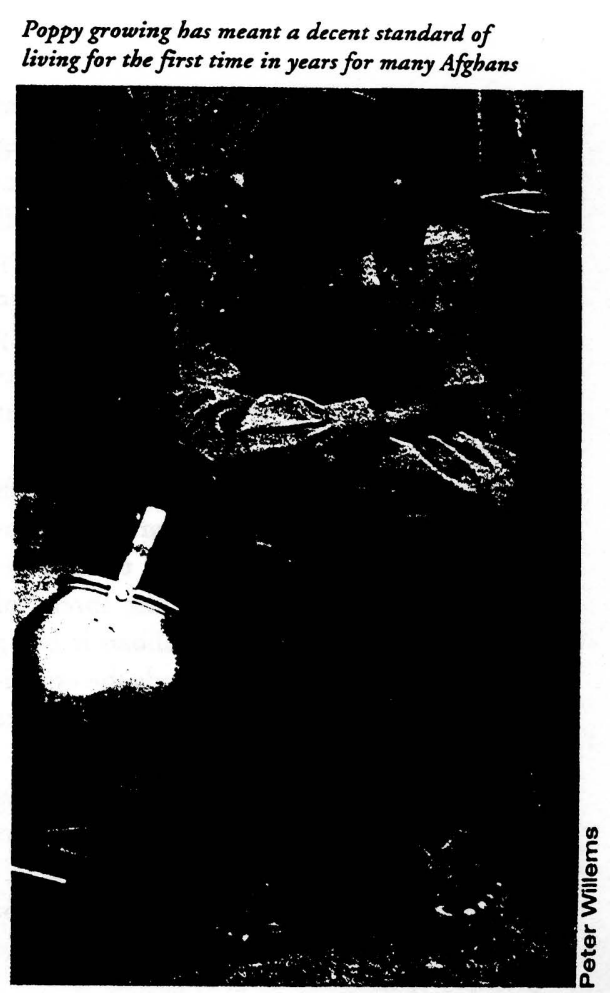




\section{Those not very nice people in Afghanistan

$$
\text { Economist 25/4-98 }
$$

America hints it may recognise the Taliban after a peace deal

SLOWLY Afghanistan has crept up the $\checkmark$ list of places that, at least in the view of western diplomats, something should be done about. On April 17th, it apparently came to the top the list. Bill Richardson, America's chief delegate to the United $\mathrm{Na}$ tions, arrived in Kabul for what he described as "tough discussions".

No American official of Mr Richardson's seniority has set foot in Afghanistan for well over 20 years. The last top gun may have been Henry Kissinger. After the Russians invaded the country in 1979, the Americans stayed clear of it, except to arm Afghan guerrillas. In his book "Diplomacy", Mr Kissinger says that the United states had nothing in common with the guerrillas. "Yet they shared a common enemy, and in the world of national interest, that made them allies." These days, America probably cares even less for the Taliban, who now rule most of Afghanistan, and practise a strict form of Islamism; but national interest has arisen again, and this was the reason for Mr Richardson's visit.

The Taliban have been far more succassful than anyone guessed when they Stivted their uprising in 1994, apparently Wh Pakistani support. A chunk of the in is is north is all that is now denied . Ituey are recognised as the governHor Saudi Arabia, which gives

them money, and by the United Arab Emirates and Pakistan. The forces holed up in the northern enclave, who fled from Kabul, are still, in the eyes of most of the world, the legitimate rulers of the country.

In Taliban-run Afghanistan there is mostly peace. There is order in the towns and the roads have been cleared of bandits. For the ordinary Afghan this is worth having after years of civil war, even if it means growing a beard to please the Taliban bigots, covering your wife from head to foot in a sack and turning up in the market square to watch thieves having their hands cut off.

In his "tough" talking with the Taliban, Mr Richardson said that America was not at all keen on the way Afghan women were treated. He asked that they should be allowed to resume unimpeded the jobs they had before the Taliban imposed restrictions on their movement. A few weeks ago the United Nations withdrew from Kandahar after the Taliban said that Muslim women aid workers, including doctors, had to be accompanied by a male relation. But Mr Richardson knows that many countries are keen for a "solution" in Afghanistan. Even Iran, an old foe of America, but a neighbour of Afghanistan, has had discussions with American officials about the problem of refugees.

Mr Richardson did not go to Kabul plead for women's rights, ticular concern for many To the north are the former solely, or even mainly, to although these are a parAmericans, among them Madeleine Albright, the secretary of state. America would like to end the uncertain status of this large country in the centre of Asia. He hinted that possible recognition of the $\mathrm{Ka}$ bul government was in America's mind if there were genuine progress towards a peace settlement. Soviet republics of Turkmenistan, Uzbekistan and Tajikistan, which are now

seen as an abundant source of oil and gas. To the south is Pakistan with its outlet to the Arabian sea. For years western oil companies have been plotting possible pipelines across Afghanistan to the sea and so to the West. At present most oil and gas has to be exported though Russia, which adds its own premium. A peaceful Afghanistan makes an alternative route possible. Taliban representatives have had talks in the United States with at least one American oil company.

But is nationwide peace possible? The northern enclave, though small, is well armed, mainly by Russia, which fears the spread of Islam ever closer to its borders. Its fighters are experienced and have their backs to the wall. Several times they have given the Taliban a terrible mauling.

After his meeting in Kabul, Mr Richardson flew to Sheberghan in the northern enclave. The Kabul crowd had agreed to a meeting with their foes, he said, and meantime would observe a ceasefire. How about it? The northerners said yes, and talks were fixed for April 25th in Islamabad, the Pakistani capital.

The talks are not likely to be conclusive, but are expected to be the start of something, presumably of a new slog by the West. A Taliban newspaper gave warning that, if Mr Richardson did not seek a solution "in conformity with the exact religious, national and present political realities", he would fail. It does not sound encouraging, but there is no alternative to having a try. Caspar Weinberger, like $\mathrm{Mr}$ Kissinger a veteran of negotiations with the Afghans, once observed that "we knew they were not very nice people," but "we had this terrible problem of making choices."
Afghanistan
The ground
Shakes again
$\underset{\text { E }}{\text { Th }}$ on om
$6 / 6-94$

M ANY Afghans are wondering what else could possibly go wrong in their stricken country. Barely a week afterta bomb blast in the northern town of Talbquan killed at least 48 people, on May 30 th a devastating earthquake, measuring 7.1 on the Richter scale, ripped through the remote and largely inaccessible northern re gion of the country. It was the second big earthquake to hit the area in less than four months.

In the shadow of some of the highest mountains in the world, many villages have been completely destroyed-isome crushed under huge landslides. In the district of Shari-i-Buzurg, the hardest hit part of the earthquake zone, dozens of villages have been turned to rubble. Shocked and dazed survivors have been searching through the debris in the often vain hope of finding some sign of life.

Many people in the region had barely begun to start rebuilding their homes and their livelihoods after the February earthquake. That registered 6.1 and may have killed up to 4,000 people. Aid woikens say that the number of casualties in the latest earthquake is expected to be higher and

that the area of devastation is much wider than previously thought. Some estimate 100,000 people could be affected. Many of those killed or injured are women, children and the elderly. Since the earthquake struck in the morning, the majority of men were outside working on their farms.

In comparison with February's earthquake, when the harsh winter conditions hampered relief operations, the response by aid agencies has been swift. Some supplies have been delivered without difficulty by road. But the helicopters and small aircraft from neighbouring Tajikistan and Pakistan that at once started to arrive in Faizabad, catrying medical and other relief supplies to be flown to outlying villages, were soon desperately overstretched. On June 2nd, Alfredo Witschi-Cestari, the United Nations' relief co-ordinator for Af-

ghanistan, urgently appealed for more helicopters and fuel.

Many of the aid agencies were already working in the area. They rapidly set up first-aid clinics in three main centres, as well as a hospital in Rostaq, the centre of the earlier earthquake. The first priority was to treat the wounded and evacuate them to the nearest clinic or hospital. As the scale of the disaster became known, aid workers said aftershocks, lack of food and health problems were their biggest concerns. Together with the need for shelter, the region is likely to require long-term humanitarian assistance.

"There may be a danger that foreign donors will get fed up hearing about earthquakes in Aghanistan," said one aid worker. For the sake of the Afghans, it is hoped that the need won't arise. 


\section{Amerikansk press}

\section{Mountains and IHT \&/6-98 \\ By Molly Moore}

KOL DARRAH, Afghanistan - The survivors of Kol Darrah huddled atop a barren ridge overlooking the rubble of what was their village before the devastating earthquake last week sent their mud homes and animal pens plunging off a ledge and down the cracked and scarred mountainside.

For seven days, the village's 50 families had waited

- without food - for outside help to discover their remote speck in the northeastern Afghan mountains, a village so tiny and so isolated that it did not even appear on a map when relief agencies began combing this rugged territory by air for earthquake damage.

And when the first help finally arrived over the week end - an international aid helicopter with sacks of wheat and jugs of oil - even the local Afghan guide could barely find the wreckage of the former Kol Darrah.

It was the bright orange and pink head scarves of the village women, sitting in a tight knot on a mountaintop seemingly in the middle of nowhere, that served as the beacon for airborne aid workers.

Mohammed Marad, his eyes brimming with tears under a deeply furrowed forehead, threw himself into the arms of the first relief worker off the helicopter. His 5 - and 10-year-old daughters were among the 10 villagers who had died beneath the rubble.

Mr. Marad, 36, said he had left his mud home early on May 30 to buy flour from a grain mill in a distant village. He thought little of the tremor he felt underfoot at midmorning as he walked home along the steep mountain paths.

"When I returned I saw the whole village was destroyed," he said hoarsely. "I nearly burst from sorrow. I saw nobody in the village. I found my two children killed, crushed by the house."

If, as local residents believe, God is angry, he could not have chosen a more formidable location to stage such a devastating natural disaster than the Hindu Kush Mountains of Afghanistan. which have defeated travelers, adventurers and armies for centuries.

More than a week after the second earthquake in five months rattled these mountains on the Tajikistan border, killing about 5,000 people and injuring tens of thousands more, international aid workers have reached barely one-third of the 84 villages and towns known to have been damaged by the quake, which measured 6.9 on the Richter scale.

All but a handful of those villages and towns are accessible to aid workers only by helicopter. Thirtyfour towns and hamlets were destroyed, and in another 21 at least 50 percent of the houses have collapsed.

"We keep finding new villages that aren't on the maps," said Rupert Colville, a spokesman for the United Nations relief effort. "We thought the February earthquake was bad. At least the villages were accessible. This one was five to six times more destructive." About 2,300 people died in the Feb. 4 earthquake.

The relief effort has been thwarted by natural and manmade catastrophes. Persistent storms have triggered landslides and grounded the three helicopters and smattering of airplanes available to relief groups. Companies that own helicopters have tried to charge aid groups as much as $\$ 7,000$ an hour for helicopter airlifts, and some crews have refused to fly in Afghanistan, considered dangerous because of a continuing civil war.

Helicopters as well as fuel are in such short supply that the staging area at Faizabad just outside the quake zone has been a chaotic battleground of relief organizations, medical teams and journalists jousting over seats.

'It's been more than one week since the earthquake and we can't get the medical teams out," said Panna Erasmus, a doctor from the London-based Irish Medical Emergency Relief International.

Afghanistan is a country without a government capable of assisting its own people. Ripped apart by warring tribal factions for the last seven years, more than 80 percent of the country is controlled by the fundamentalist Muslim Taleban.

One of the few pockets of Afghanistan not under Taleban control is the mountainous northeastem region that was hit by the earthquake. Taleban leaders said they believed the double quakes in the area were God's revenge on the inhabitants for refusing to accept Taleban rule.
"In almost any country that has an earthquake, you have an army, an infrastructure," Mr. Colville said. "This is the only place where you have a massive disaster and almost everything has to be done by agencies. The rehabilitation from the first quake hadn't even gotten off the ground.'

Those were among the reasons that Mr. Marad and the other residents of Kol Darrah had camped out on a desolate hillside for a week. They were subsisting on milk from a few goats and cows and a spinach-type grass that grows wild in the mountains. They were sheltered only by a few scrubby trees and flimsy tents constructed of rugs pulled from beneath the rocks and mud that were once their village.

When the mustard-colored Tajik helicopter leased by the International Committee of the Red Cross landed on a muddy hillside across the ravine from the site of the village, the mountainside came alive with dozens of men and children running as far as a kilometer to greet the chopper and the sacks of wheat and plastic jugs of oil that it carried.

Two men labored down a steep hill carrying Azada, 25 , who gave a doctor only her first name, and her 3-yearold son huddled under a blanket. Both had spinal fracnures and had waited more than a week for the trip to the Faizabad hospital, a 25-minute helicopter flight away.

\section{- A Tug-of- War Over Helicopter Fuel}

Pakistan said over the weekend that it would contribute three helicopters to the relief operation in Afghanistan, but only after a bizarre tug-of-war with aid workers over vital fuel supplies, Agence FrancePresse reported from Faizabad.

Three Pakistani military helicopters were stranded in Faizabad after running low on fuel while ferrying Deputy Foreign Minister Mohammed Saddiq Kanju to talks with Afghan faction leaders. The Pakistanis infuriated aid workers by demanding the entire relief operation's fuel stocks to fly their stranded helicopters home.

Hundreds of tons of food are piled up beside the airstrip in Faizabad, but there is no way to get it to many of the villages perched on mountainsides or hidden in deep ravines.
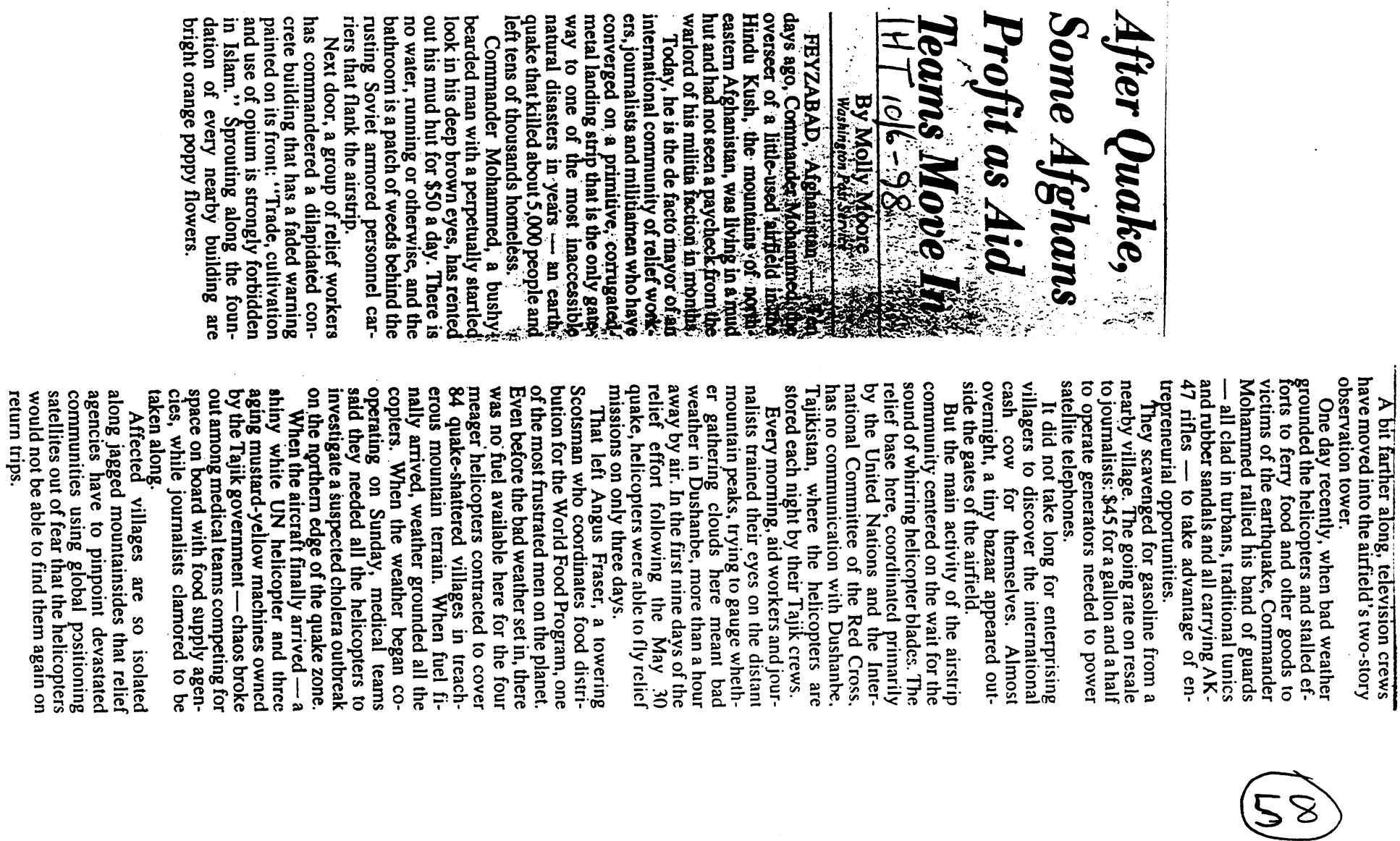


\section{Dangerous Liaisons}

\section{Drugs are driving politics in Afghanistan and Pakistan}

\section{By Ahmed Rashid in Lslamabad}

everal times each month, a heavily armed convoy leaves on a long dusty journey from Afghanistan's southern province of Helmand. The Toyota landcruisers mounted with anti-aircraft guns and anti-tank rockets are guarded by hundreds of soldiers belonging to the Taliban, the Islamic fundamentalist regime in Kabui. They are protecting the mosî lethal and lucrative exports that strife-torn Afghanistan has to offer: opium, and its derivative, heroin.

In the past year, the narcotics trade from the Afghanistan-Pakistan-Central Asia region has exploded, according to the U.S. State Department and the United Nations' Drugs Control Programme. Afghanistan alone is now the world's largest producer of opium, ousting Burma from that dubious spot for the first time (see related story on page 26). Tajikistan and Kirgyzstan have also become significant opiate producers.

The brisk traffic in drugs has dangerously altered the region's dynamics. Heroin profits are fuelling the war machines of both the Taliban and other Afghan warlords-stymieing any chances for peace in Afghanistan. The Russian mafia has meanwhile sucked Central Asia into its heroin pipeline, while Pakistan and Washington are squabbling over the sincerity of Islamabad's anti-drugs efforts. "Drugs istdetermining the politics of this region asnever before," says an Islamabad-based amímbassador of a Western country. "We equate it now with other serious threats such as Istamic fundamentalism, terrorism and potential economic collapse in some of these countries."

Ed Addiction also is on the rise, despite Islamic injunctions to the contrary. New Asian narcotics gangs are emerging, with the money and power to bribe governments. Meanwhile, the West is receiving ever-more abundant supplies of hard drugs, at increasingly cheaper prices. "The real crisis is that nobody knows where all this will end," says the diplomat.

There is ample reason for concern: According to the UNDCP, Afghanistan in 1997 produced 2,800 tonnes of opium, half of it in Helmand, the seat of the Taliban. This was a quarter more than it produced in 1996. Washington's estimate for
1997 is more conservative- 1,265 tonnes. In Afghanistan, drugs, like war, have long been a fact of life. But in the past few years, narcotics profits have been poured into the war effort, as the battle for Afghanistan intensifies. The Taliban needs hard cash to maintain its army. Unlike the volunteers that fought the former Soviet Union, many of the Taliban soldiers today are paid mercenaries. Since Afghanistan boasts virtually no economic activity, the drugs industry is the only way to raise cash.

The Taliban's drug-fighting exertions therefore are hardly enthusiastic. A UNDCP-proposed deal in November promised international funds to help Afghanistan's poppy farmers grow substitute crops, but the Kabul regime's initiative remained largely on paper. A determined UNDCP is now trying to persuade the Taliban to sign an agreement for a poppy-eradication plan in Kandahar in exchange for development assistance. A similar scheme is already under way in Nangarhar, the second-largest opiumproducing province in Afghanistan.

In February, the U.S. State Department

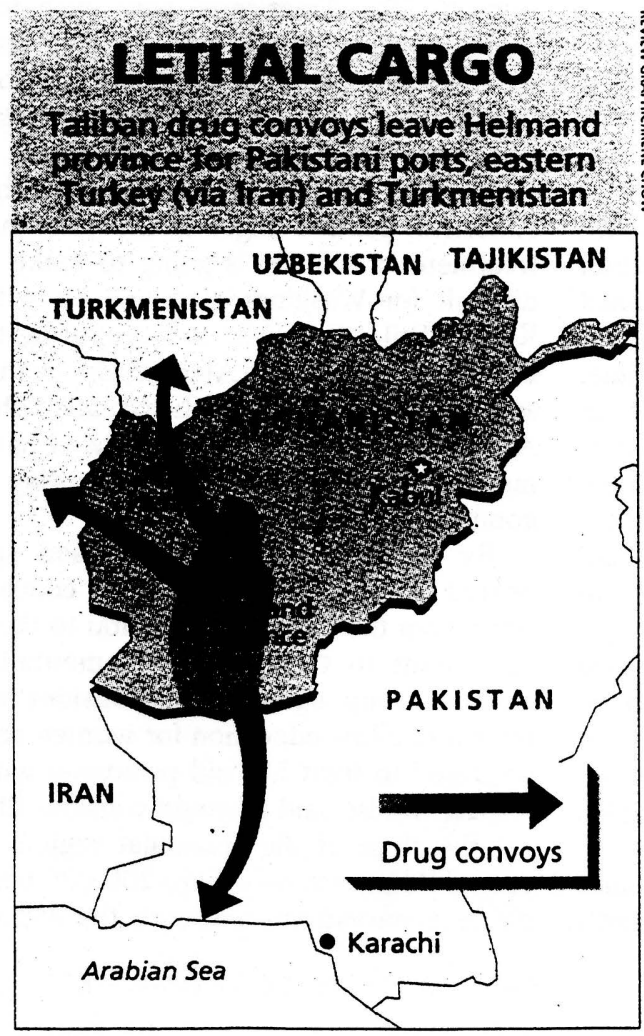

FAR EASTERN ECONOMIC REVIEW lashed out at "the inaction and lack of political will of the Taliban faction, which controls $96 \%$ of Afghanistan's opiumgrowing areas, as well as substantial drugstrade involvement by some local Taliban authorities." Also in the loop are many Afghan warlords who have set up their own laboratories for locally made opium, much of which used to be refined in neighbouring Pakistan.

The region's lucrative drugs trade has also attracted Asian criminals, as well as the Russian mafia, which infiltrated Afghanistan during the Soviet occupation in the 1980s. The Russian gangs move heroin through Central Asia, Russia, the Baltics and onwards to Europe. The abundance of drugs has dramatically increased consumption at home-only $42 \%$ of the region's opiates are actually exported, the UNDCP estimates. Pakistan claims it has 3 million-5 million addicts, compared with virtually none in 1980, when the Afghan war began.

This is despite a drastic drop in poppy cultivation from a high of 800 tonnes in 1980 to a mere 24 tonnes in 1997, according to the UNDCP. (A U.S. estimate puts the 1997 figure at 87 tonnes.) The decline in poppy growing was largely due to the success of crop-substitution projects in Pakistan's North-West Frontier Province. Since then, however, Washington has complained that Islamabad has made "no progress in crop eradication," that poppy cultivation has climbed $21 \%$ and anti-drugs enforcement has deteriorated. Separately, the UNDCP in March withheld the release of $\$ 6$ million to Pakistan because of bountiful poppy cultivation in the NWFP's remote Dir area.

$t$ is the American accusations that have angered Pakistan most. Islamabad believes Washington's complaints-and its subsequent refusal to certify Pakistan's antinarcotics efforts-were provoked by a growing bilateral spat over Ayaz Baloch, a Pakistani citizen working for the U.S. Drug Enforcement Administration in Islamabad.

Baloch organized an embarrassing sting last year against a Pakistani airforce officer who was caught in New York trying to sell heroin. A furious Pakistani military arrested, tried and then sentenced Baloch to 10 years in jail for entrapping the officer. An outraged U.S. insisted that Baloch be released in order not to scare off other DEA workers hired locally. In early April, the military court reduced Baloch's sentence to five years, but didn't release him. U.S.-Pakistan relations remain tense. 


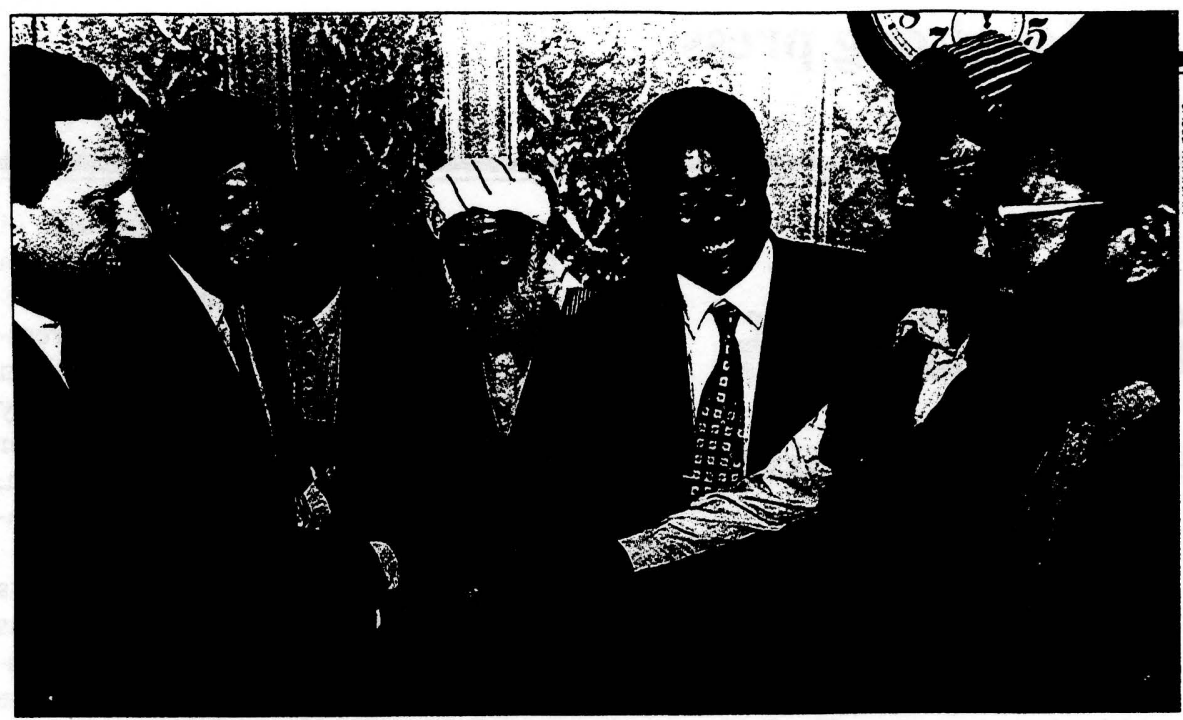

Back in the game: Bill Richardson (second from left) meets opposition leaders in Washington's first major diplomatic initiative in Afghanistan in 25 years.

A F G H A N I S T A N

\section{Dropping In}

\section{Stakes are high in new U.S. peace push}

\section{By Ahmed Rashid in Islamabad}

B ill Richardson, President Bill Clinton's foreign-policy troubleshooter and ambassador to the United $\mathrm{Na}$ tions, has always been fond of parachute diplomacy. A top U.S. administration official dropping in on a foreign troublespot invariably plays well on television back home. But even Richardson was surprised at the reception he got on April 17 from Afghanistan's bearded warlords.

As the United States made its first highlevel diplomatic foray to the country in 25 years, Richardson was deluged with gifts of carpets, saddlebags and turbans. He was aiso invited to watch a game of polo-played in traditional fashion with the headless carcass of a sheep. In Kabul, the Taliban government, which has banned all music and television, allowed U.S. TV crews to film its leaders for the first time. And Kabul's regular Friday spectacle, in which convicted murderers and thieves had their throats slit or arms amputated, was postponed for Richardson's benefit.

After meeting both the Taliban in Kabul and the opposition Northern Alliance in Sheberghan in the north, Richardson got a commitment by both sides to meet face to face for talks. The parleys would be held under United Nations auspices in Islamabad on April 27. He also got a promise from the rival groups not to launch offensives against each other.

The strength of these promises remains to be seen. As a Western diplomat points

APRIL 30, 1998 out, "this war has gone on for 20 years and we have heard all this before." Besides, the spring warring season has arrived.

The more important point, however, is that after a gap of nine years, the U.S. is back as a player in Afghanistan. This time, it's not about stopping communism, but keeping the region safe for the oil and gas pipelines that could unlock Central Asia's mineral wealth. There could also be a major spin-off: The Americans' new push for peace in Afghanistan puts them, for once, on the same side as Iran-a bit of good fortune that could serve to improve relations between Washington and Teheran.

It is not going to be plain sailing. The American public's anger at the Taliban's treatment of women is going to make it difficult for Washington to line up with Kabul. Still, the U.S. is "prepared to engage intensively in Afghanistan in this search for peace," said Richardson. The Afghans, he added, "see America as having the ability, with its power, to play a good role."

By the time he left, Richardson appeared to have extracted several concessions from the Taliban in addition to their agreement to talk. The fundamentalist Islamic group agreed to reconsider its refusal to allow education for women and promised to treat UN aid personnel with respect. It also said it would consider lifting the siege of the Hazarajat region in central Afghanistan-where 200,000 people face starvation-and curb the export of drugs and terrorism.

But no sooner was Richardson out of the country than the backtracking began. "This agreement is very important, but there is no specific talks proposal for the Islamabad meeting," said Taliban spokesman Wakil Ahmad Mutawakil minutes after Richardson left Kabul. In Kandahar, supreme Taliban leader Mulla Omar, whom Richardson did not meet, said there was no broad agenda for the talks.

What was behind the appearance of compromise earlier? "The Taliban want to buy time because they are under increasing international pressure to ease up on their hard line," says a European diplomat. "These will be talks about talks ... It's a start."

Meanwhile, the Taliban's long-running dispute with aid agencies over the gender issue is now at flash point. The UN pulled out of Kandahar in March, when Taliban leaders beat up international aid workers. Now, the Taliban have refused to accept Alfredo Witschi-Cestari, who oversees UN aid for Afghanistan, as leader of a delegation to discuss the gender issue.

Public pressure in the U.S. for Washington's re-engagement in Afghanistan has been fuelled largely by women's-rights lobbies. But Washington has important geostrategic reasons for its new involvement. Not least among these is the need for a quick peace so that American firms can build oil and gas pipelines from Central Asia across Afghanistan to markets in South Asia. But some analysts believe Washington's primary aim in getting involved in Afghanistan is to improve relations with Iran.

"Afghanistan will create opportunities for Iran and the U.S. to work together on important regional matters," said Richardson. U.S. officials say Afghanistan is "a test case" of whether Washington and Teheran can work together on other issues, for instance in the Middle East.

$\mathbf{T}$ he Taliban, for its part, wants the U.S. to recognize it and persuade the UN Security Council to keep vacant Afghanistan's UN seat, currently occupied by the Northern Alliance. Islamabad supports the Taliban line. Pakistan also accepts the Taliban's views on a future government, which would include Afghanistan's ethnic minorities-but not their present leaders. This is unacceptable to the Alliance, which is drawn from the minorities, or its backers, Iran, Uzbekistan and Russia.

With so many seemingly insurmountable differences between the various sides, nobody is expecting a quick fix. But, as Richardson put it, "in this business we make peace one day at a time." 


\section{Taliban ban clapping during soccer matches}

KABUL (AFP) - Afghanistan's national team - but only players from the parts of the football side is to take to the field for the first time in years but players and supporters will have to comply with strict guid
ruling Taliban said Monday.

The religious militia has outlawed clapping in the olympic stadium here so onlookers will be ordered to encourage both sides equally with cheers of "Allahu Akbar" (God is greatest).

Sportsmen also have to be modestly dressed with long trousers and sleeves prescribed for all events, the militia-appointed head of the national olympic committee Mullah Abdul Shukur Motmain told reporters.

The Taliban, who have imposed : what they say is the world's purest Islamic state, have banned celevision and video, cinema, music and dancing, as well as tight restrictions on sportsmen and spectators.

However Motmain said the movement's strict dress code should not be an impediment to the players selected for a new national side.

"I hope we have no problem playing in the dress Islam has provided to us and of course we hope to win," said the turbaned sports chief.

Recrujts are now heing selected for the warring nation held by the Taliban will be considered.: city, will vie for popularity with normal Friday night fare at the stadium - gory public punishments.

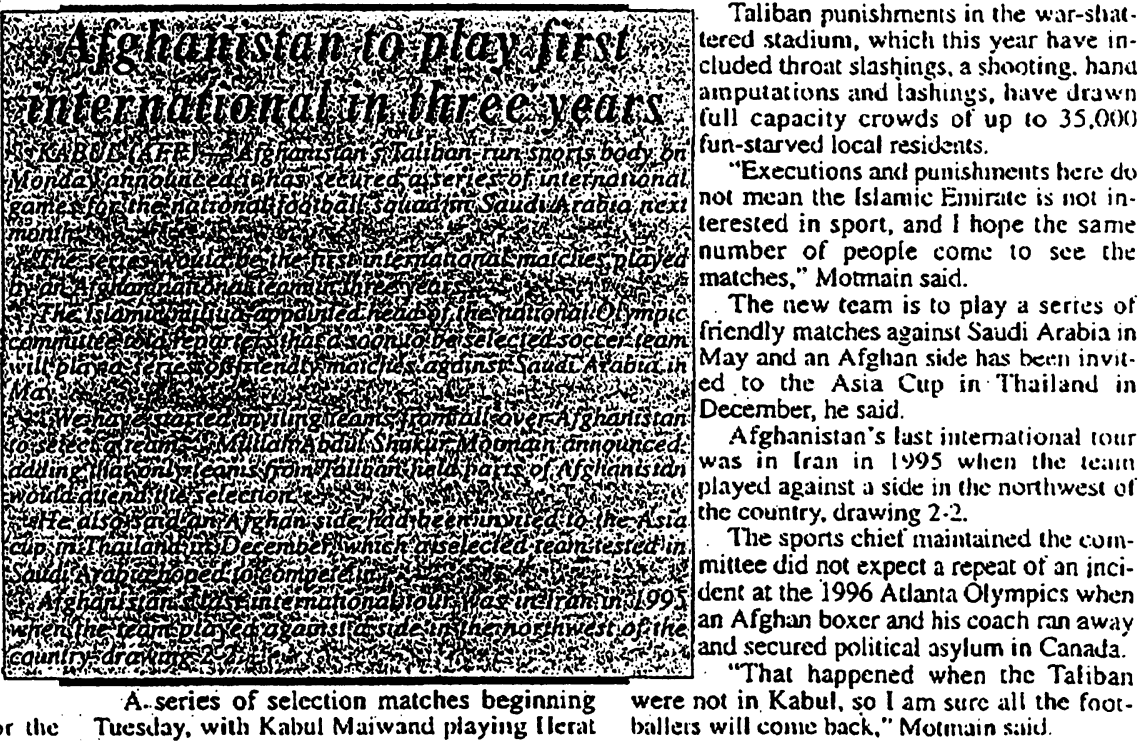

\section{$F_{r} 980424$ Northern Alliance team arrives UN works out modalities of intra-Afghan dialogue}

From SIKANDER HAYAT

ISLAMABAD - OIC's Afghanistan specialist Ibrahim Saleh Baqar arrived jere Thursday night to join the Afghans !alks that the organisation has co-sponsored with the United Nations.

Other participants are coming on Friday (today) for the talks to be held Saturday, for which there is no agenda. Some confidence-: building measures, however, may. emerge from this face-to face encounter in more than a year.

The representatives of the Taliban and their opponents met -thricenastyeas in Lola bodivith out success.

One important upshot of the talks which is being held in the

(Continued from Page 1) of the OIC, Ibrahim Saleh Bakar is also scheduled to arrive here today (Friday) to attend the meeting.

Representatives of warring Afghan factions will be here by Friday (today) to have face-10face' talks to discuss the immediate issues of maintaining ceasefire, exchange of prisoners, preparing the ground for holaing an ulema commission meeting and provision of humanitarian aid 10 the affected Afghan people.

Meanwhile, a nine-member prestigious Convertion Centre can be a ceasefire, :0. which the two sides had agreed in their meetings with US special envoy Bill Richaróson.

Reports say that since Richardson's a air-dash :": to Afghanistari last week. no major clash has taken place in the country where factional fighting a popular pastime.

The two sides had also agrced to enabling relief workers to pur? sue their activity in a safe cnvironment, not to permit the use of Afghan soil for terrorism and to improving the lot of the Afghan However, at the meeting on Saturday being heic under the rubric of steering committec to set

April 25.

The delegation of the Northein Alliance includes Nawlawi Faz Hadi Shinwari, Mzwlawi Altaur Relhman. Dr Mohammad Rasul Taleb, Sayed Mohammad Sharif Nasarzada; (substitute for Sheikh Abbas Fazi). Aboul Hassan. Yasser, Sayyed Mohammad Hashii, Sarjuddin Khan, Waki Abdul :Wahab asd : Mawlawi Mohammed Shah.

The Taliban government will be represented by Mawlawi Waki Ahmed (head) Mawlawi Abdul up an ulema commission, ceasefire and release of some PoWs may be the only topics for discussion. with some positive outcome. APP adds: UN officials had a hectic day on Wednesday, preparing groundwork for meeting of the steering committee.

The head of Afghan mission in Islamabad. N. Gobi, who will preside the steering committee's meeting, held contacts with officials of the Foreign Office and representatives of the Taliban and the Northern Alliance.

Diplomatic sources told APP that necessary modalities for the steering commiztee's meeting came uñder discussion.

The assistant secretary general (Continued on Page 2)

Representatives of the Afghan opposition said that they were fully united and ready to settle issues with Taliban through dialogue.

Talking to the newsmen at the Islamabad airport. the coordinator of the delegation of the Noriterm Alliance, Engineer Abdul Rahim. said that they would be paricipating in the steering committee's meeting with sincerity of intent.

Enginecr Abdul Rahim added the talks would focus on the for mation of a uiema commission besides dealing with the issues of 

-

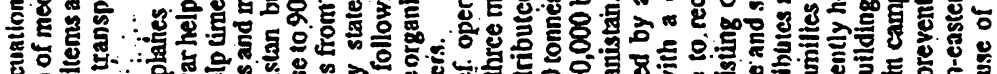

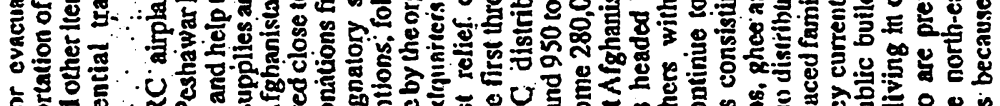
¿

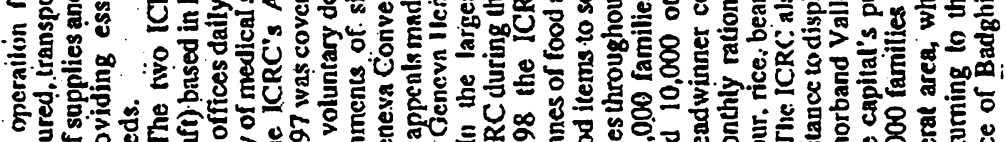

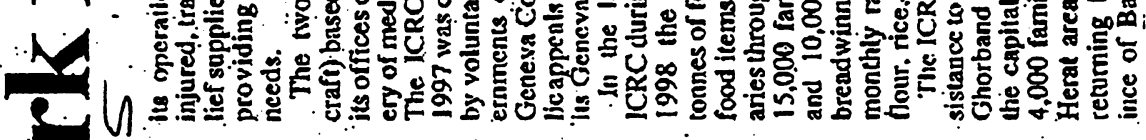
N

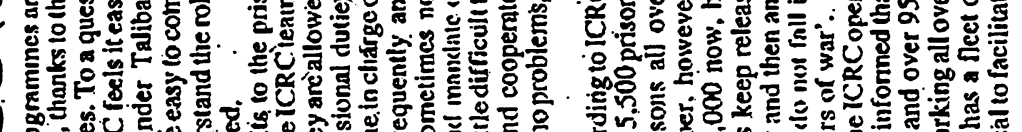

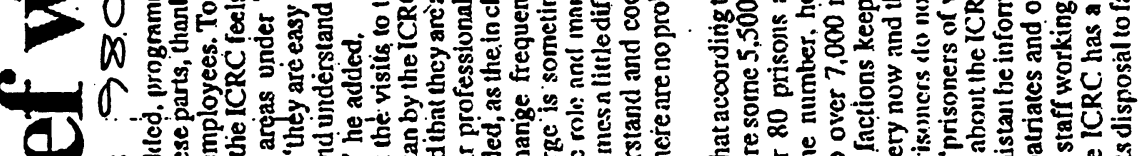
(1) n - 14030

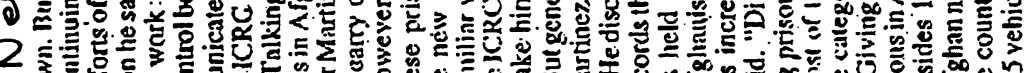

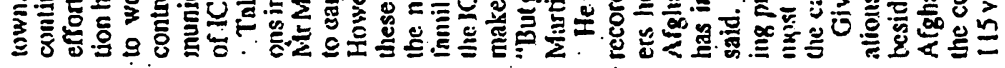

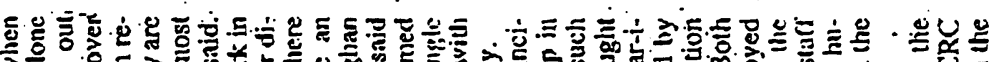

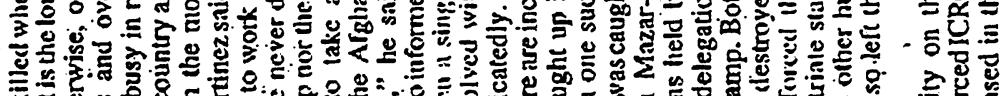

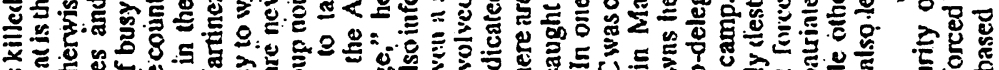

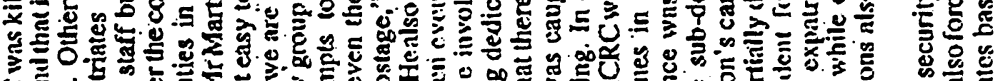

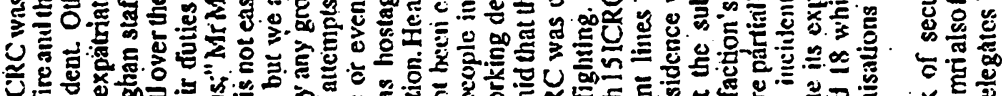

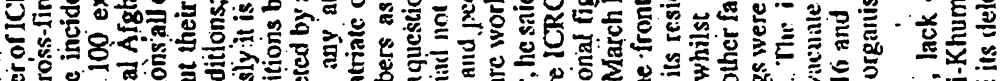
ô.

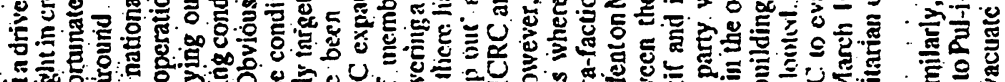

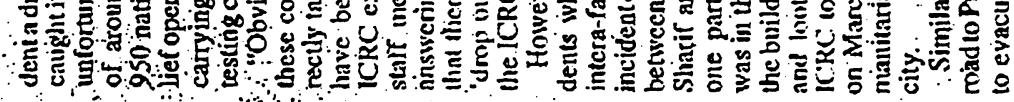

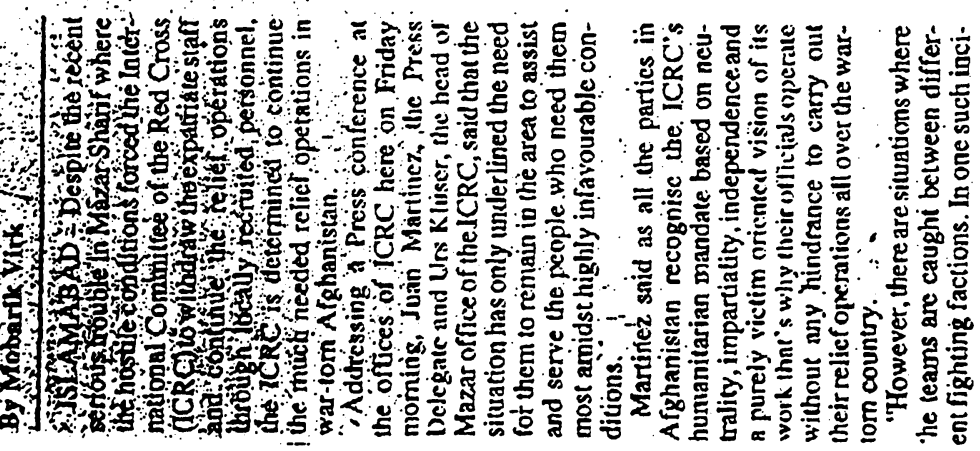

\section{Seven Afghans Fo slain in armed clash}

FAIZABAD (NNI) - At least seven people were killed and many received bullet injuries in an armed clash between two groups over mine dispute in Badkhashan, northern province of Afghanistan on Friday.

An Afghan group had started digging at mine of valuable stones at Khwaja Muhammad lills us the snow melted due (o) change in climate in Badkhashan, $40 \mathrm{~km}$ from here.

The situation became tense when another Afghan group claimed ownership of the mine. After exchanging some hot svords both the groups exchanged firing, killing seven people on the spot while large number of members belonging both sides received bullet injuries.

The injured were admitted to Faizahad Hospital.

\section{Natoon 980425 Horses bringing UN aid to isolated Afghan region \\ $\because$ GENEVA (AFP) OThe UN:s World Food Programme (WFP) has sens four teams on horseback to the tsolatod Afghan region of Hazara- jat whene entite villages are facing starvation due to food btortage aggravaled by civil whats as The hid caravans, which ane car- rying 500 tonnes of potaloes and 100 tonnes of grains and hiśctuits, will take $1: 1$ days to reach uhe afto di: ed areäs of Sharistan, Mališsa Behisud and Ghör ä WF spókes main said Priday: \\ In Behsud alone some 35,000 piople have been described by non- governmental organisations as suffering from chronic malnutri- tion. \\ Supplies cannot be sent from the south becaluse of a blockade im- pused by the country's ruling Tali- ban regime, while the area to the north is controlled by" anti-Taliban fórces.?}

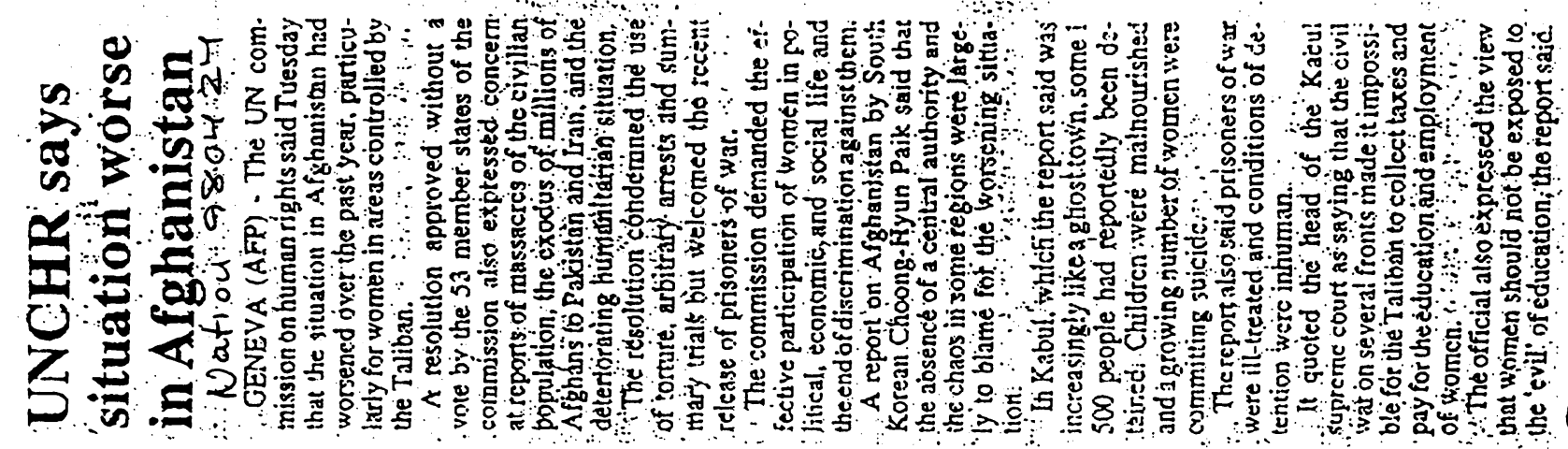




\section{Afghan shops dismantled during operation clean-up}

By our correspondent

NOWSHERA: The district administiation nas launched an operation clean-up and dismantled shops and kiosks. of Afghan refugees along the railway track and the main road.

Afghan refugees said their shops and kiosks had been bulldozed by the Municipal Committee, Akora Kiraitak aided by the district administation. They claimed the operation ijies and forced thousends others out of jobs. Business at tine local veg. etaioie market has also been affected. "ivere will we go now that the intemational assistance to us has also roingee.

AiY central presicient Senator Ajnal Knattair criticised the operaicn clean-up and asked the government not to snatch jobs from people ii it could not give employment to them. He demanded immediate rehabilitation of the affectees and warned the government to.take re. had affected more than 10.000 fambeen declined," said an Afghan nedial measures before it was too iate.

Addressing a jirga of the Afghan 'retugees at Mohajir bazar on the main GT Road near Akora, the ANP leasier sait the Afghan refugees had rendered great sacrifices for the lib! eration of their country from foreign frices. He said he had personally spoken to the chief minister on the it but warned his party wouid chaik Dit its own course if the government failed to rehabilitate the affectees.

- Khattak was also critical of the municipal authorities which, he claimed, received taxes froin the iefugees but bulldozed their shops without giving; them ary prior notice. The authorities; he said, had forced thousands of people out of joos and caused millions of rupees iosses to tirem.

ANP MNA, Wali Muhammad Khan ot Mesri Banda alleged that even the istaelis did not treat the Palestinians the Way the Afghan refugees had been treated. issue who had promised to lcok into
Red Cross keeps its staff out of northern Afghanistan

ISLAMABAD The International Red. Cross-annoưf cedj Friday that it will nót let its staff leturn tó notthern: Afghanistan until the opposition alliance that rules the ares can guaransee their safety.

There will be no more permanent expatriates in Mazari-e-Sharif," the neadquarters of Afghanistan's ant:Taliban alliance, said Juan Martinez, a spokesman for the Red Cross. When we do this that mears things are quite difficult," he said. "We have to think about security .... it is quite dangerous to let them stay." Another lotation - either in one of the neighbouring Central Asian countries or in the Aighar copital of Kabul - will be used as a Red Cross headquarters for northern Afghanistan, said Martinez.

The Red Cross pulled its eight international staff out of Mazat-esharif last month after ferocious fighting Rashid Dostum and Stiite Hiuslims of broke out betwieen partners in the at liance-One. of the homes. of, the Red Cross staff and an office in Mazar-e. Sharif were destroyed during the fighting between Uzbek warlord Hezbie-Wahadat.

The alliance brokered a peace agreement between the tro groups and on Thursday the alliance announced they would disarm every fac. tion in Mazar-e-Sharif. They unged foreign aid workers to return to the city.

Whis is not forever ... if in three months we see the situation is quite good and the factions can control their troops we will return," sid Mlartinez. However, Martinez said the Red Cross programmes will not be effected by the decision. International workers will periodically risit Mazare-Slurif and its Afghan star will keep the programmes running. - AP
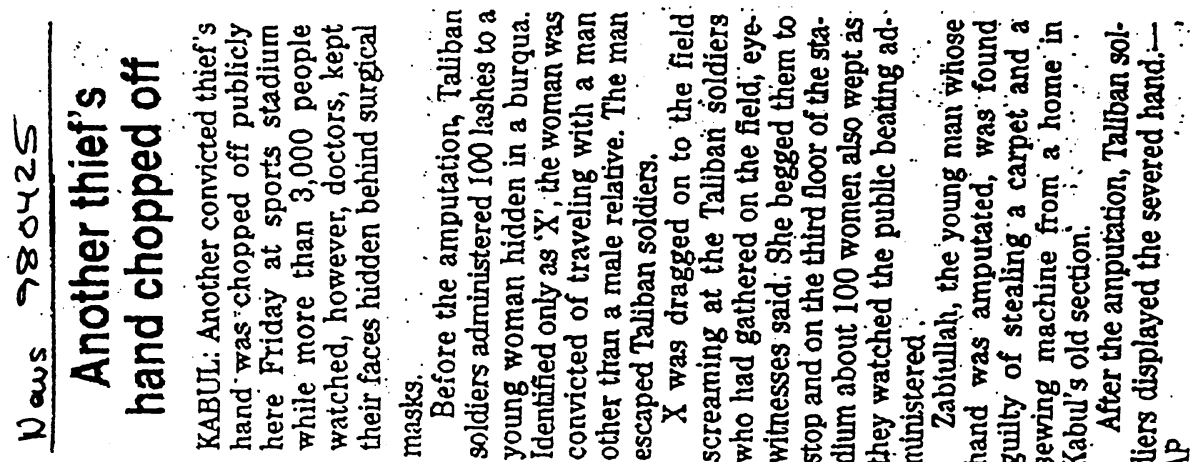

\section{to ban poppy cultivation \\ Natrou 780424}

KABLL (AFP) - US diplonnats vis: ited the Afghan capital Thursday for talks with anti-narcotics officials in the Islanic Taliban tegime, officials here said

$\therefore$ But the Taliben's drug-control chief asserted that the militia had no plans to enforce their ban on the cultivation of opium popipies unless farmers received massive intetnational aid :!: $: \because \cdots, i^{i}$ $x$. The gates of the Islamic Emiratd of s. Aignanistan are:open to all agencies fifivived in drug control,' : secretarj; general oirthe state commission: for drig cobluob Mir. Najjibullati Shams toid reportarsis

He saict two "drig experts from the -US diplomatictissioling Pakistan had arrived for talks on diu joontrol is -

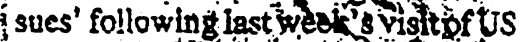
ambassador to the United Natons Richiardson $\therefore$

He said the two diplomats were onj hete to discuss the growth of ophin poppies in Afghanistan; but gave no further oetails on the talks. A ? in sty. $\therefore$ Despice the presence of the US diplowats yidhe Taliban-hicld capital the official once sogith asserted that the cuilitia llad tio intetitiơn ô enforcing 3 ban the frintounced last yéar ot poppy

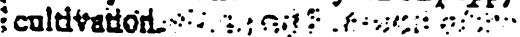
i 'If you äre making poison and heroin out of it this is not the faule of the 'Afghar grower,' Shams argued. 'Ou? poor farmers need to feed their kids."

'If the legitimate financial'demanos' of out farmers are thel by advianced countries suffering from :narcotics. I guarritice that cultivation tótild finish tomorrow, he added, $3+195$

Afghanistati, which bas been at was. for 18 years, is a major producer of opium, and the Taliban-held castern province of Nangahar is currently in the rnidst of its annual harvest, which UN officials say should be a bumper crop.

Most opium here heads for Europe, after it is processed into heroin along Afghanistan's porous borders and smuggled through neighbouring states.

Opium is grown both in the Talibancontrolled two-thinds of the country and areas controlled by the custed Kabul government in northeastem Afgianistan. Hashish is also widely produced throughout the country. 


\section{Is there an end to the \\ $\underset{\text { News } 480425}{\text { Sufferings of Afghan women? }}$} By Gul Rukh Rahman

ISLAVABAD:The night echoed with the cries of a couple as armed men dragged their 18 year old daughter out of the house. This was to punish her aather who failed to give them the winereabouts of his son. The men sus. pec:ed that he was involved with a facion opposing them.

Even after two years nobody knows rinat happened to the girl but the couple found the bullet ridden bcdy of their son in front of their house. Broken and terrified for the sa:ety of their other son, they left Kaoul and came to Pakistan

Zuiekna lived in Karte Seh flats near Kabul airport. She and her sister ware raped by a group of Mujahideen about throe years ago. Their fault was the same as that of the girl raped in lare 1996.

But these were not the only groups ino committed such crimes against women in Afghanistan. The cominumists, the Hujahideen and the Talibar, they have all done this. Some even used rape as a weapon to intimicate their opponents.

However, the Taliban became hrown all over the world because of their ultra-conservative policies.
In late 1996 when the Taliban took over'Kabul many' people throught it would stop the 18 year oid bloodshed and bring peace to the country.

But little did we know that the once welcomed presence of these men would turn into a nightraare for us." says Jan Afshan, a Kabul woman - wito left the city because she could nct work there anymore.

Most Afghans do not accept the cranges that Taliban have brought particularly about women. They find the Taliban brand of Islam unaccept. able but can not do anything acout it.

They have shut down girls schnols, stopped women from working and have made it mandatory for them to envelope themselves in a shroud like burqa if they venoure out oi the house, " says a spokesperson for the Revolutionary Afghan Tiomen's Association (RAWA).

They have closed girls schools saying they are un Islamic. But where does the Qur'aan say that women should not study", asks an .tfghan woman who used to teach at one of the schools now closed by the Tal-: ioan.

Women health professionals have also been asked to stay home and men are not allowed to treat women.

"If in the times of the Prophet, women could lead armies, cared for the wounded and could carry busi. ness activities; why can't the Afghan women:do so in this time and age," asks an Afghan nurse now living in Peshawar.

Even Islamic Iran finds the Talibar's brand of Islam unacceptable. In: 1996, Ayatuliah Ahmad Jannati; one of iran's most popular cierics, criticised Taliban for their treatment of women. He accused them of abusing the religion by limizing women's rights.

After almost two decades of fighting, there are more than $50,000 \mathrm{war}$ widows only in Kabul. The Taliban had promised to pay them and those prevented from work but 30 far nobocty has been paid a penny.

The Taliban justify their actions by saying that-Islam wants women to stay home: If this is true how do they explain the business ventures of Hazrat Khadija and Hazrat Ayesha who led an army," asks the school teacher.

"The worst part is that we bo to endure this humiliation in the name of Isiam which is as much Qur religion .as it is of the Taliban," she says.

During change in emphasis; the programme will continue to work in the current areas of operation with special focus on Kabul and Kandahar, Western Paktia, Herat and Logar.

The other targeted provinces include Farah, Ghami, Heliniand, Kin: duz, Nangarhar, Nimroz, Badghis, Parwan,

Takhar, Zabul, Paktia, Balkh, Baghlan and Kapisa $\quad \ldots \quad$

The MAPA will further improve safety in the programme and reduce. mine incidents involing the demining staft:

The programme also aims to improve the cost effectiveness of opporting repatriation and renabilitation projects. erations while new concepts will be

thers of high priogt squined
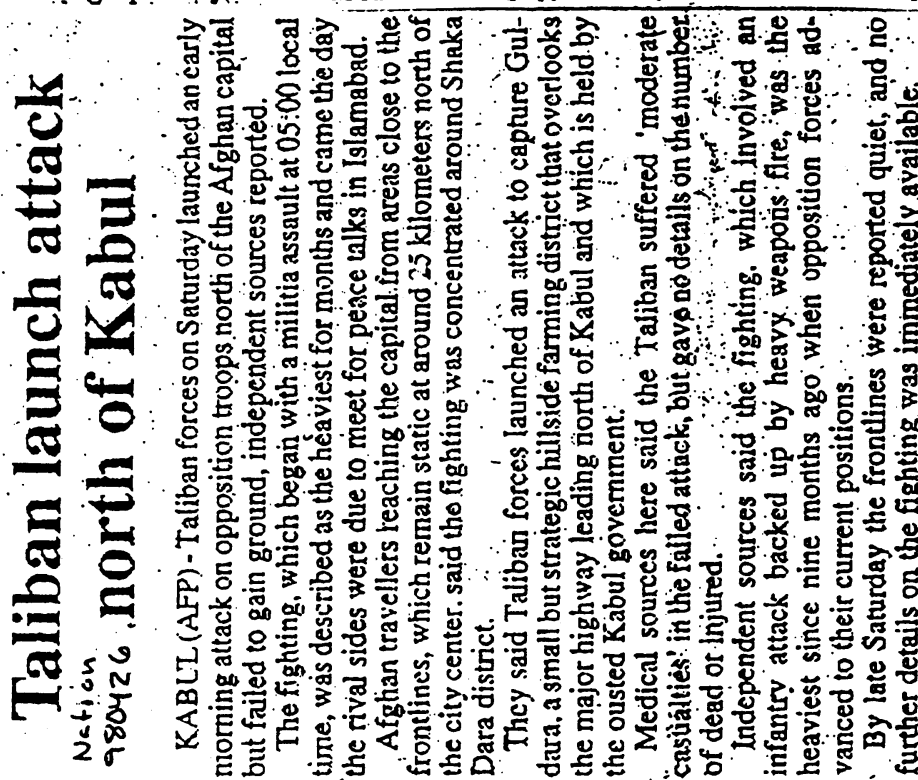
developed for clearance of low mined area - PPI 


\section{EU may cut aid to Afghans if situation not improved \\ News 980429}

ISLAMABAD: A European Union delegation Tuesday warned internationai aid to Afghanistan would decline if insecurity prevailed.in the north and relief workers were denied access to areas heid by the Taliban.

"The European Union remains wilis:g to assist Afghanistan but only on the basis of globally accepted principles" of aid distribution. Mukesh Kapila, head of Britain's Conflict and Humanitarian Department said.

Kapila's 20-member mission visited Afghanistan in preparation for the Afginan Support Group (ASG) meeting being held in London on May 5.

The meeting to be co-chaired by Britain and the United States, is a "symbol of international concern," he told reporters on return here.

The ASG meeting to be attended by major Afghan donors, will discuss aid and political factors to adopt a "coherent approach"

Aighanistan, he added.

The EU last year spent some $\$ 150$ million on humanitarian aid to Afghanistan which was two-thirds of the total aid.

But he said future aid might be restricted if difficulties persisted in reaching the beneficiaries in a principled manner.

Stressing that security in opposition held northern Afghanistan had "deteriorated" due to factional fighting and "looting", he expressed dissatisfaction over restrictions on women's access to work and education in the Taliban held 70 percent of the country.

"If the current situation continties, I can't see the same volume of aid can be maintained," he said.

Kapila who met Mullah Rabbani, the head of the Taliban's ruling council in Kabul, said the militia officials "understood very clearly" the message of the EU team.

The hardline militia officials said they wanted to carry on discussion and dialogue with aid agencies.

They wanted continued assis. tance to rehabilitate hospitals, schools and health services, but "there were no particular concessions" to carry out the work, he said.

Kapila said the EU: "fully" supported the United Nations in its Afghan aid efforts.

"If the UN is unable to resume its full scope operation over the next few weeks" and the security in the north continues to deteriorate and difficulties remained in getting into the Taiiban area then "clearly the volume of aid is going to go down," he said.-AFP
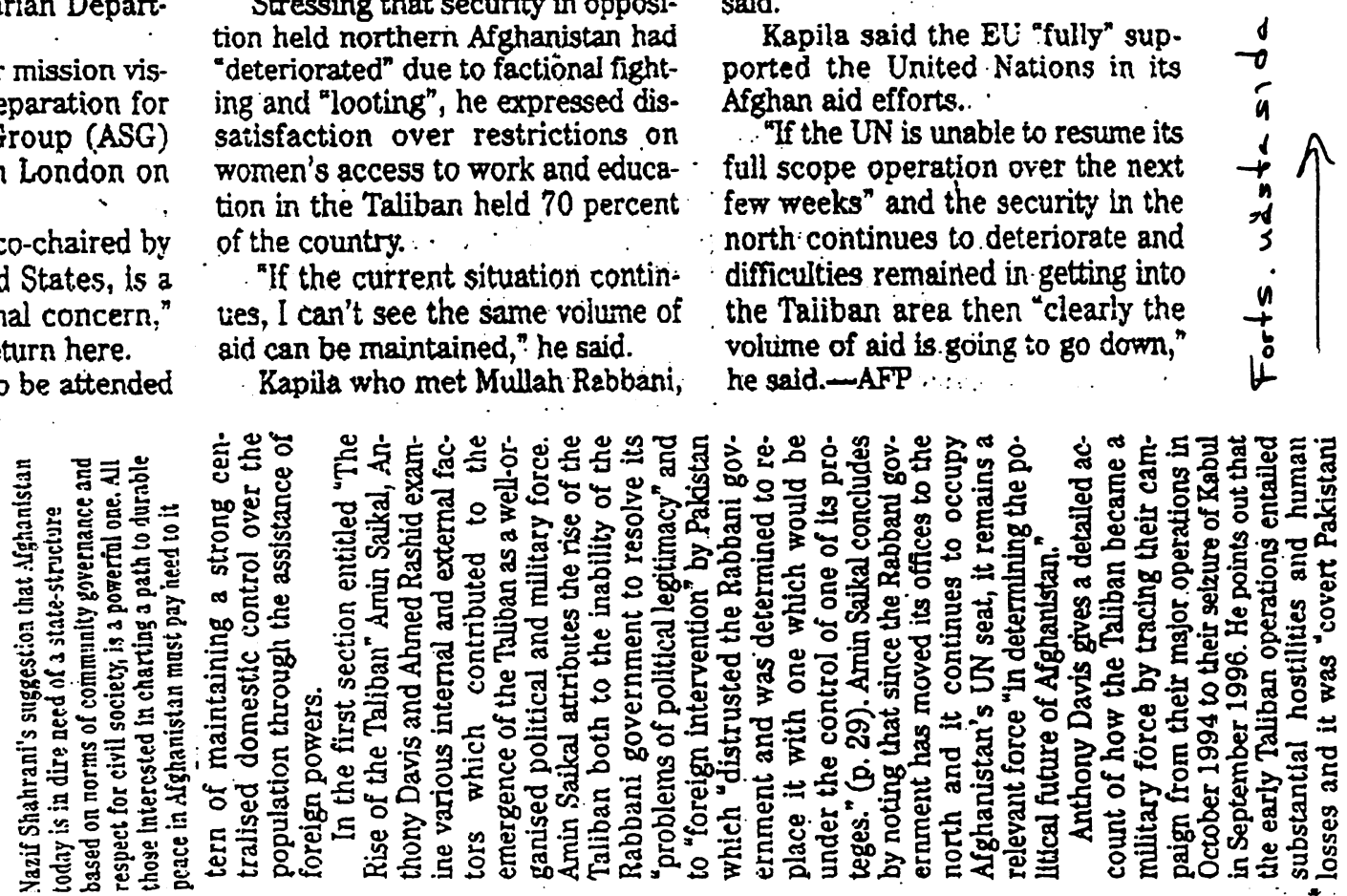

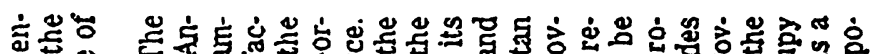

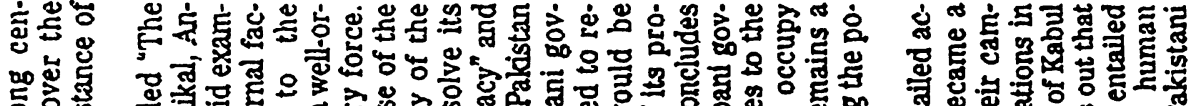

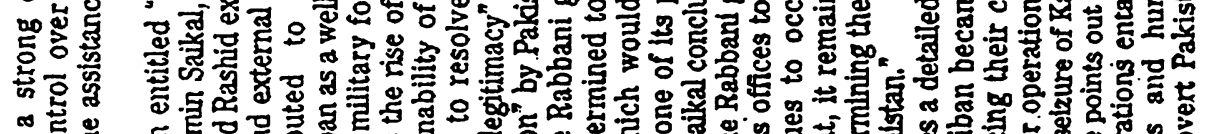
0 荡要

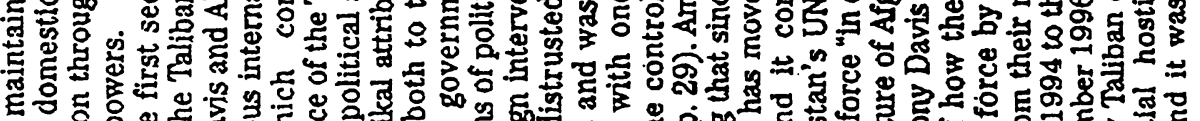

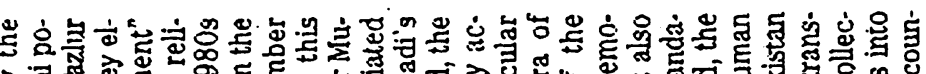

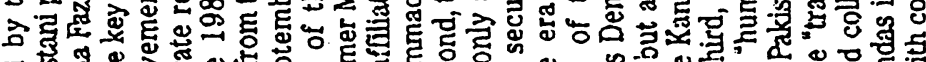

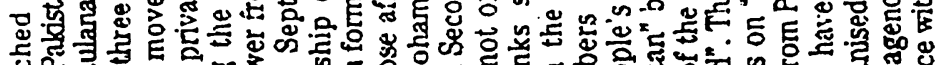

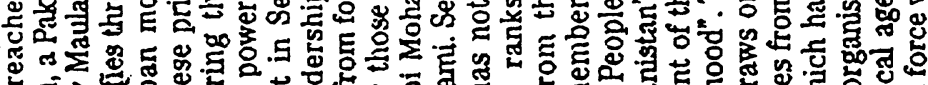

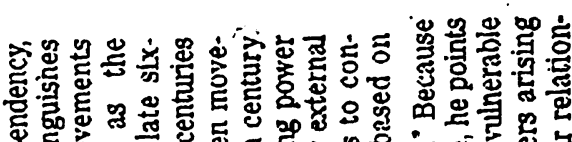

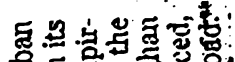

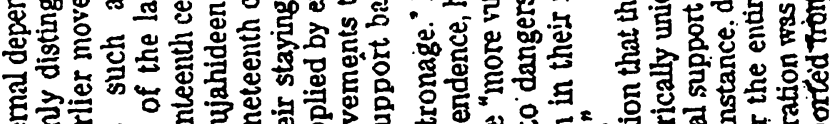

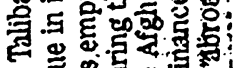

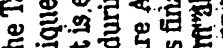

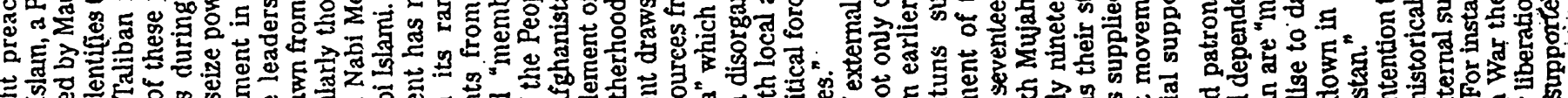

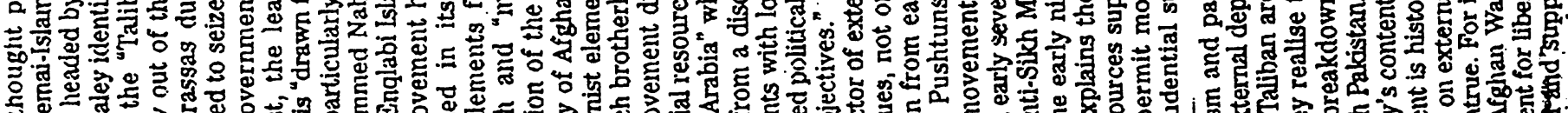

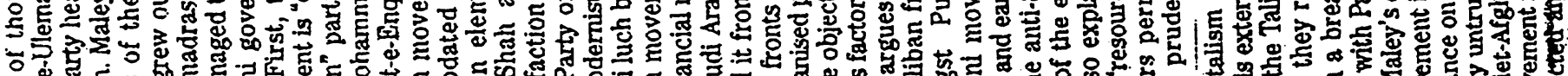

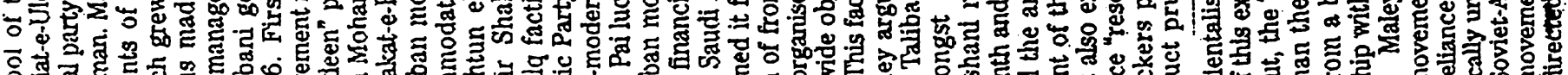

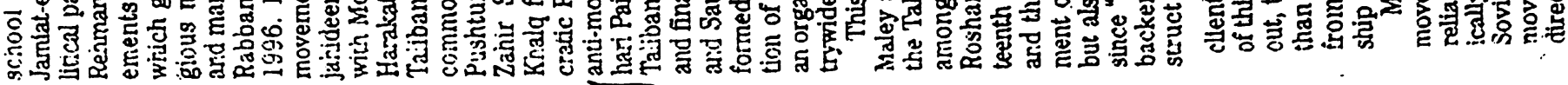




\section{Dealing with the Taliban \\ support for the Taliban" which played} a fundamental role in their "expansion as a regional and national force." ( $p$. 69). However, despite having "benefited from Pakdstani aid and advice," Anthong Davis argues, "the Taliban are anything but Palistani puppets." (p. 71). He points out that between early 1995 and the summer of 1997 , the Taliban leadership "on numerous occasions" tumed down the Pakistani advice which "has not been to its taste." (p.71). He concludes by noting that Islamabad may have shot itself in the foot by rewarding the "unblirking rigidity of the Taliban" and "their military adventures" with the "prize of diplomatic recognition" in May 199? as this "rash" decision has only permitted "these enfant terrible of islamic politics" to "pursue their own agenda

without sanction" and with impurity.

Ahmed Rashid explores the various strands of Pakistan's organic links with the Taliban. He convincingly shows how overtime, the Taliban have not only successfully torged a symbiotic relationship with difierent elements of the Palistani state and its society but more importantly, taking full advantage of the absence of any coherence in Pakistan government policy cowards Afghanistan, the Taliban thate been able to exploit these linkages to their political advantage in the dangerous patron-ilient game played by Pakistan. He writes: “... the fact remains that with the constant infighing and overlap on Afghan policy within the Pakistani establishment. . Pa'istan's strategy towards the Taliban was characterised as much by drit as by determination. . . And the Taliban had become masters at using these differences within the Pakistani estailishment to their advantage, ex-

tracting the maximum benefits from Palistan without giving any political concessions in return. Thus instead of using its clout with the Taliban to exert leverage on them on key political and social issues Pakistan appeared to fintter away its authority and respect amongst many Afghans ... "(p.38). The domestic ramifications of the Taliban's rise to power in Kabul for Pakistan, according to Almed Rastid, are nothing less than grave: "3N5 mass movement for an Islamic revolution" in Pakistan "will almost certainly be joined by the thousands of Pakjistani madrassa students who have fought alongside the Taliban in Aighanistan"; and with "growing public sisillusionment with the political system . . . the threat of an Islamic revolution in Pabistan has never been
grister".(p.89).
T 7 he second part of the book entilled "the Taliban and the World' examines the way in which the Inited States, the Russian, the nelightouring Central States, Saudi Arabia and Iran have tried to cope with the Taliban phenomenon. In his account of the American approach to wards the Taliban, Richard Mackenzic suggests that while "there is no clear evidence tinat the Clintor: administraton implemented a policy to establish the Taliban" (p.97) there is no gainsaying tine fact that Washington had all along pursued "the policy of making do with the Talibas" out of defer. ence for LNOCAL's game plan of " $\mathrm{Pax}$ Taliban". (p.97). Contrary to this tolerant American attitude towards the Taliban, tie Russian and Central Asian states have evinced a policy of susiained hostility toward the Taliban mainly because of their shared view that "Aighanistan under Taliban rule would inspire Islamic activism among their oun populations; possibly !eading on to politic:al instability or even an lslamic-style revolution". (p.1i6).

The history of rivalry between Saudi-Arabia and Iran in Afghanistan is Irace d by Anwar-ul-Haq Ahiady. He argues that, among other things the dynamics of Saudi-Iran competilion are located in the emergence of two

rival "Ifformal alliances" of foreign powers who are engaged in a strategic competition to gain access to the energy resources of Central Asia via ifghauristan. Iran, along with Indian and Russia represents one regionai axis which is opposed by a rival coalition comprising Ssudi Arabia, United States and Pakistan. This rivaliry between sorelgn powers played out on Afghan soil, according to Ahady, is an important source of continued strife ind conflict in Afgharistan. $\therefore \therefore$

Michael : Keating and Nancy Dupree discuss issues of kumanitarian. assisiance and gender roles in Afgharistan under the Taliban in the third section of the book. Both argue that cespite daunting challenges pased by Taliban's pursurit of non-co. operative behaviour, humanitarian as. sistance work must continue in Afgharistan if the future Afghan gen. erations have to be saved from the scourge of war.
7 he most significant contribution in the fourth sertion of the book $\mathcal{A}$ is by Nazif Shahrani who, adopting a poltical ecological approsech, argues that instead of taking the Afghean state and its "constitutive principles of paternalism, nepotism, tribalism, and ethnic-regional favouritism" as given, there is dire intellectual and political need to question the adequacy and appropriateness of prevailing form of post-colonial Afghan state, and examine whether it may actually breed communal violence and conflict. He argued that the Taliban, like their predecessors, by "fighting for exclusive control of state power" and "gover. nance structures combined with their blatant disregard of local, provincial, regional, etinic and sectarian community governance interests and structures" have done their country a great disservice as these policies have ensured the "perpetuation of the current intercommunal strife." (p. 235). Is an altemative, Nazif Shahrani, suggests, all those who care about Afghanistan, must "encourage the formation of a central government based on democratic principles of free elecilon and power-sharing among all interest groups in the country." $(p$. 240). Such a government, according to him must be committed, at a minimum, to work towards the following national goals: 1) "drafting and ratify. ing a new national constitution reflecting the post-Communist and postjihad national needs, aspirations and political, ecological, and economic realities in Afghanistan," 2) "guaranteeing the constitutional rigints of community self-governance at the local, district, provincial and regional level throughout the country," 3) "creating a national administrative structure to ensure a uniform implementation of new constitutional laws by local selfgoverning authorities throughout the country,". 4) "instead of disarming local communities, possibly recruiting some members to form a national asmy, with the rest coordinated into local community-based national guard detachments to defend the country against external threats." ( p. 241).

Nazif Shahrani's suggestion that Afyhanistan today is in dire need of a state-structure based on norms of community governance and respect for civil society, is a powerful one. All those interested in charting a psth to durable peace in Aighanistan must pay heed to it.

The writer teaches intermational relations at Quald-i-Azam University Iolamabad 


\section{Demining operation to continue in Afghanistan, says UNDP official \\ Wews 980427}

ISLALABAD: The United Vations Development Programme's (JNDP) demining operation in war-shattered Aighanistan has succeeded in clearing mines irom 250,000 square kiometre area. There is an estimated 6000,000 so km: mined arca in the entire Afghanistan.

The dem!ning operation backed by the international community, particularly European Community and Japan, will continue till clearance of the mines, said Sukehrro Hasegawa, UNDP's deputy regional director (New york) for Asia and the Pacific. in an interview with newsmen here on Sunday:

UNDP's demining experts, beside clearing mines, have trained dighans in demining. They have protided mine awareness briefings to over 3.8 million Afghars and have trained and ernoloyed more chan 3,900 mine scrion staif.

The purpose of demining is to enable displaced $\Lambda$ fghans return to their homeiand and cultivate arable land in Afghanistan. Hassegawa said this will create a possibility of such people earn ineir livelihood by engaging themseives in agricultural activities and rising livestock.

Wines asked how long will it take to clear Afghanistan of mines, he said, "It is enormous undertaking. The way we are ricing. it will take many years." However. he said, the international communisy have been suoportive of demining operations being carried out by C.TDR. There had been a lot of support from European Community and Japan to back the operation which corsumes Rs. 20 to 25 million a year.

linder Mine Action Programme for Afghanistan (MAPA) training to Afginans is given for a few months and irciuding on job training. He said, there had been a few casualties in which Afghans deminers were killed and some received injuries. Sniffing dogs were specially imported and at least 35 dogs were being further irained io aelp trace the mines.

Explaining the main objectives of mine awareness, Hasegawa, who is also deplix. assistant administrator of LNDP, ive York, said, it is to reduce accidents. injuries and deatis caused by mines and other explosive devices by educating people on the identification and avoidance of risks associated with living in an contaminated environment. MAPA will continue its mine axareness activities and will teach people who may be exposed to the mincs. They will include settled citizens, refugees and internally dispiaced people, nomads and any oth- ers living or working inside Afghanistan.

The MAPA also aims io identify and improve opportunities for expansion of mine awareness through mine action NGOs, and other approuriate mecharism including formal and in. formaj education systems.

The MAPA has so far delivered mine action support in 24 out of 29 provinces of Afginanistan. In ail 197 operations were undertaken in 18 provinces. At the end of November 1997, the Mine Action Programme for Afghanistan had cleared 130 so $\mathrm{km}$ of high priority area contaminated by mines and destroyed more than 086.813 devices, surveyed and mapped 184 s $\mathrm{km}$ of mine contaminated land.

Hasegawa was here to examine demining training being carried in $\mathrm{Pe}$. shawar for operation in Afghanistan The second aim was to meet Afghan National Network of women's Association Group. an NGO based in Peshawar.

Meanwhile, UNDP Under Programune for Empowering the Community had provided funds to comrturities in 21 provinces of Afghanistan. An amount of 14 to 15 million dollars has been atlocated for the purnose. This programme began in 1996. - APS

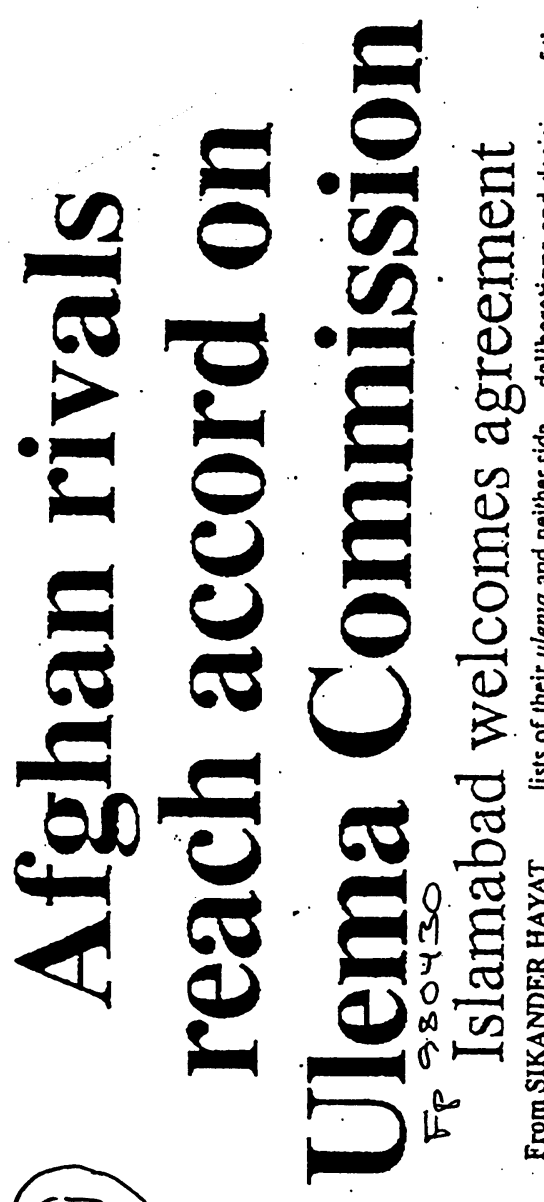

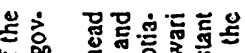

i. 8

น

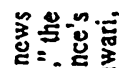

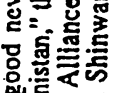

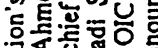

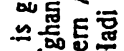

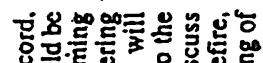

马्ष

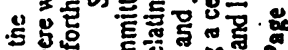

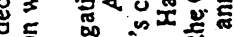

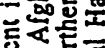

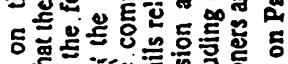

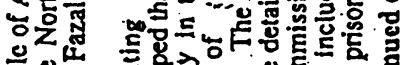

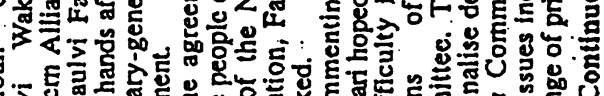

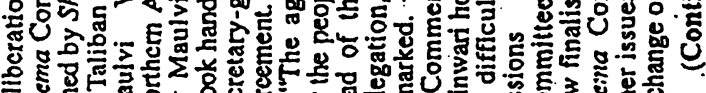

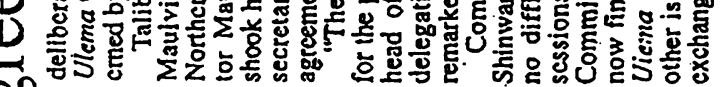

20

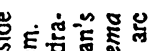
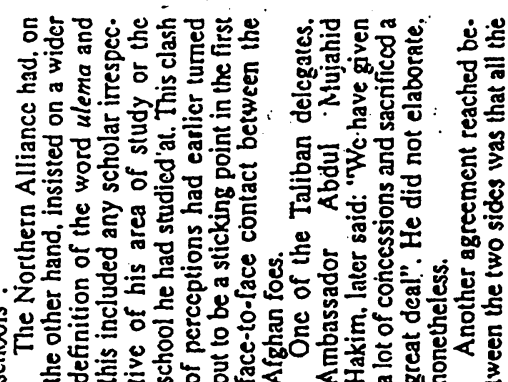

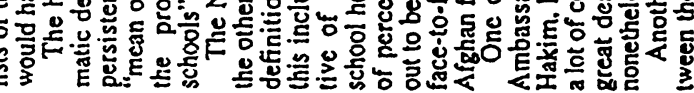

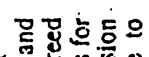

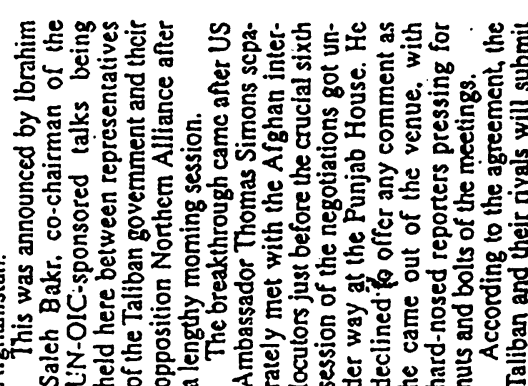

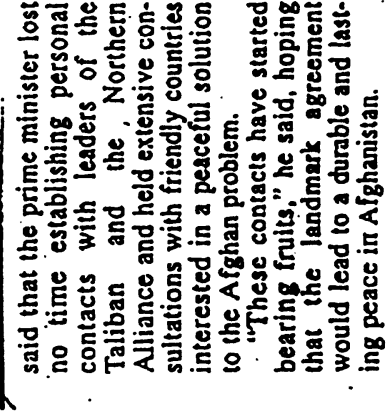

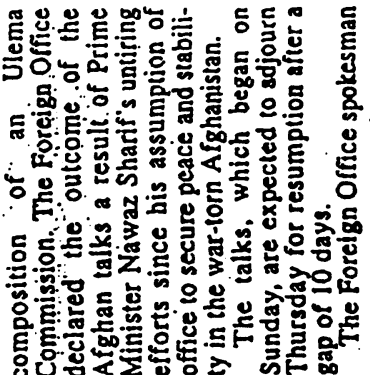

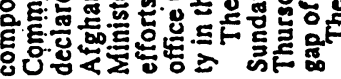

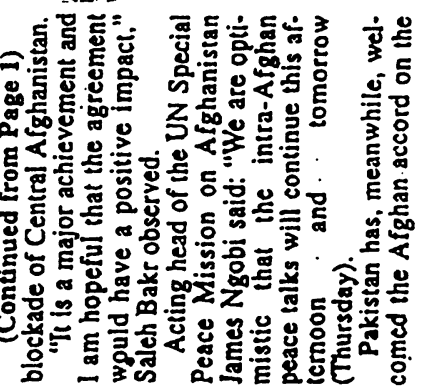




\section{People facing starvation in central Afghanistan: WFP News 980427

$$
\text { Appeals for } \$ 300,000 \text { to purchase food }
$$

ISLAVAABAD: Some areas of central Afghanistan have reportedly been hit by famine, the Worid Food Programme (WFP) said Sunday.

The WFP officials said reporss have started to pour in as routes are being cleared after the winters, reports VOA. It has become possible for the local leaders and interna. tonal relief workers to enter the arca with the melting of snow, the officials said.

The WFP has appealed for donations worth $\$ 300,000$ to purchase food.

For the last some months, the Untied Nations has been warning that the Taliban are hampering food supplies to central Afghanistan.

The UN said over a million people are facing problems and 1,60000 people are facing starvation as a resuit of this blockade.

A big devastation is in the offing which would affect hundreds and thousands of people, the officials said.
The Taliban say they are not end. ing the blockade because they to not want to see their rivals receiving iood supplies. The Taliban propose inat the UN should use the route of ine Northern Alliance for sending iood supplies to central Afghanistan.

The UN officials sajd it nzs not possible to do so as security prodiems still exist there. The food supplies sent in an emergency by air to ine central province of Bamjan early this year were halted when the Tal. iban had attacked a local airport.

The WFP officials said the food supplies have exhausted in the aree and we have started efiorts to tespatch potato and whest to the area on emergency basis.

The officials said two staif missions of the WFP were going to the area to ascertain the exact situation of famine. The Taliban and the Vorthern Alliance will discuss the issue of lifting ban on desparcin of $r e$. lief goods in their on going salks in islamabad.-APP

\section{Taliban publicly execute one, flog two in Kabul \\ News 580503}

KSBUL: At least 20,000 residents of the Afghan capital gathered Friday in the national stadium to see an alleged murderer shot dead and two whisky drinkers flogged, repoiters witnessed.

First on the fortball turf were Absul Rahman and Abclul Ahmad, who received 80 firm lashings with a wide leather strap for being caught in possession of a bottle of whisky and confessing to a two-year habit. Next up was Wali Mohammad - sentenced to death for murder who received three fatal shots from a kalashnikov fired by the brother of the viction.

'I'he Itdiban, whe hold Kaloul and have imposed strict Islamic laws, give the relatives of the murdered the option of carrying out the death sentence personally or forgive the convict.-AFP

\section{Lifting of road blockades again derails Afghan talks}

News 980501

By Anwar Iqbal

ISLAMABAD: The Hezb-i-Wahdat's demand for lifting of road blockades caused the rival Afghan factions to postpone the Islamabad peace talks for two days Thursday but they pledged to return on Sunday after consulting their leaders.

The marathon 11-hour session ended at midnight as dejected Afghan delegates walked out of the Punjab House. "We blame the Hezb-i-Wahdat party and Iran for cerailing the talks," said Wajil Ahmad Motawakkil who nas leading the Thliban delegation.

"But we will come back on Sinday after consulting our leaders in Kandhar," he said. He said there were differences within the Northern Alliance as only the Wahdat party was insisting on discussing this issue.
It is the Shiite population of central Afghanistan which suffers most from the blockades and the Wahdat party represents them.

The World Food Programme says tens of thousands of people are facing a serious shortage of food and medicines in Bamijan.

"We wanted to follow the agenda which clearly said that an key issues should be discussed in the ulema commission and not in the steering committee," said Motawakkil.

Last minute joint efforts by the Lnited States and Pakdstan also failed toproduced results on Friday. PakIstan's special envoy Iftikhar Murshid and US ambassador in Islamabad tried their best to convince the two sides to reach some agreement before they disperse but apparently they did not succeed.
US ambassador Thomas Simmons Ir joined the talks at $8.40 \mathrm{pm}$ and re mained at the Punjab House for more than two hours.

On Thursday, when the two sides; appeared to have reached a stalemate on the ulema commission, Simmons Jr successfiuly pleaded with them not to veto each other's candidates.

But Motawakkal refused that there was any pressure on them from Pakistan or the US. "The American am. bassador arrived after we had already resolved the issue (of the ulema commission) on Thursday" he siaid.

After the Friday evening sessipn. the deputy chief of the UN special mission 'for Afghanistan, James. Ngobi, announced the postponement of the meeting saying that the meeting pould reconvene in Islamabad after a two-day gap. 


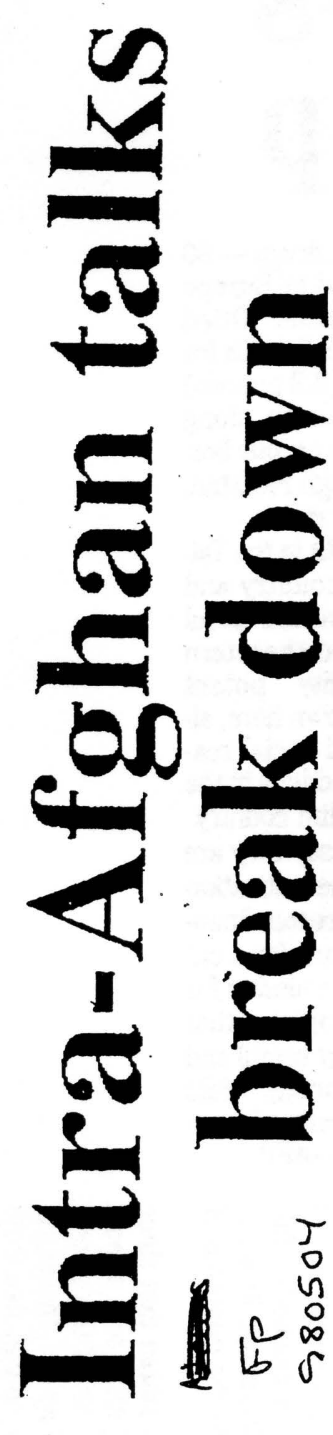

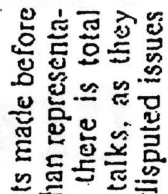

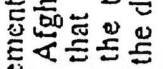

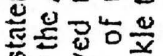

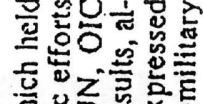

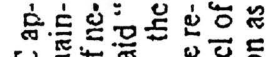

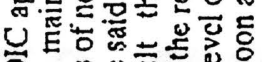

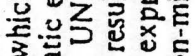

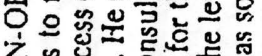

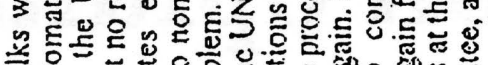

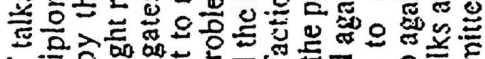

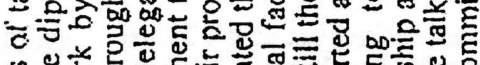

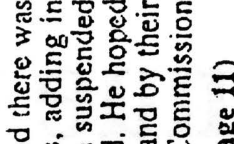

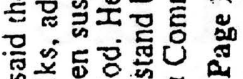

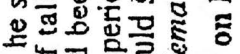

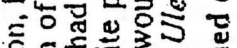

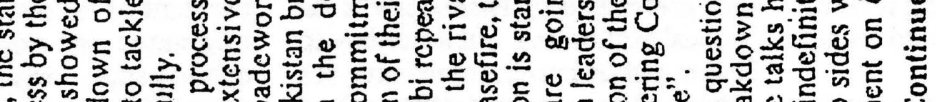

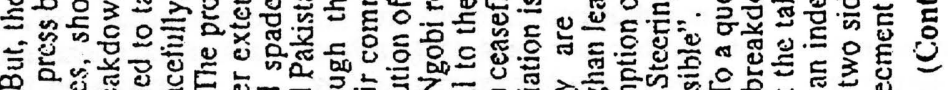

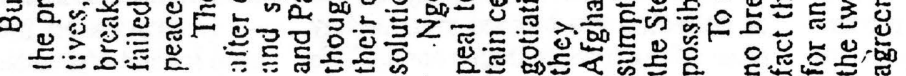

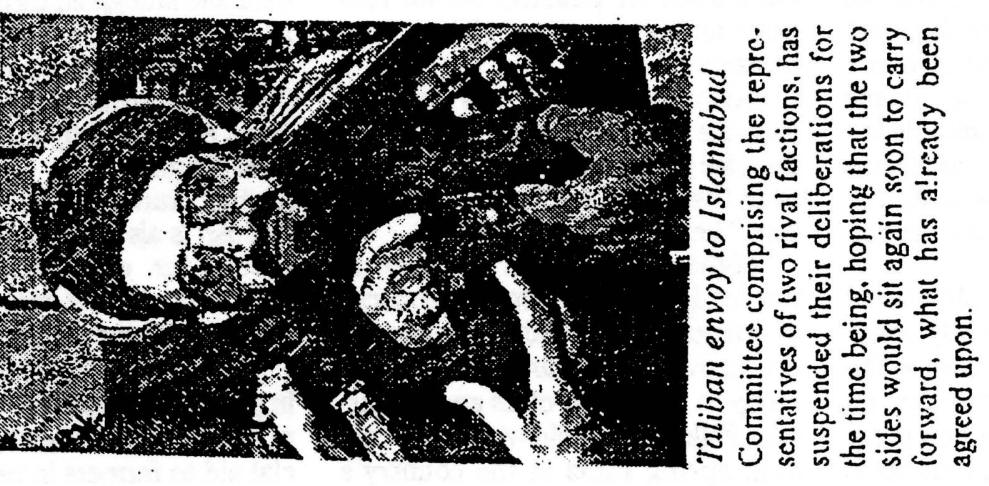

\section{言}

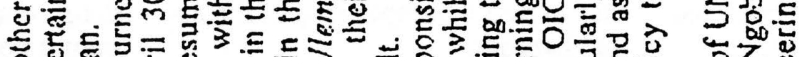

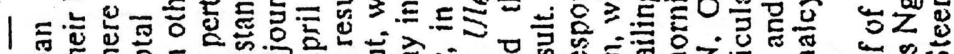

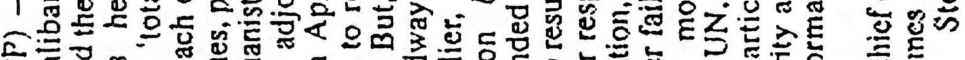

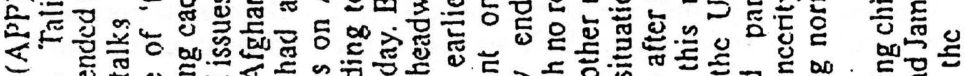

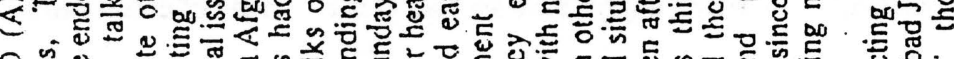

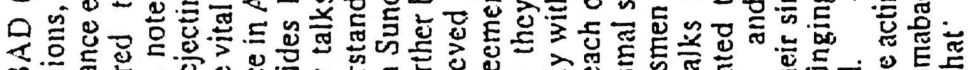

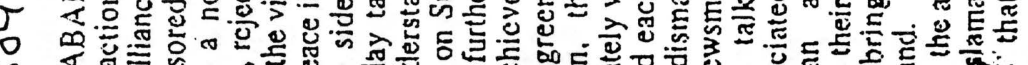

设

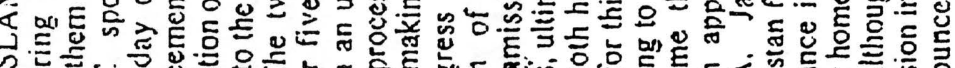

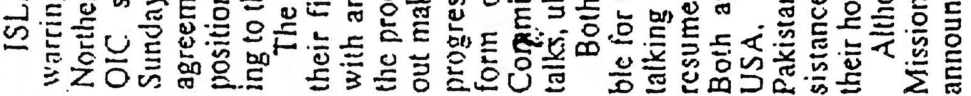

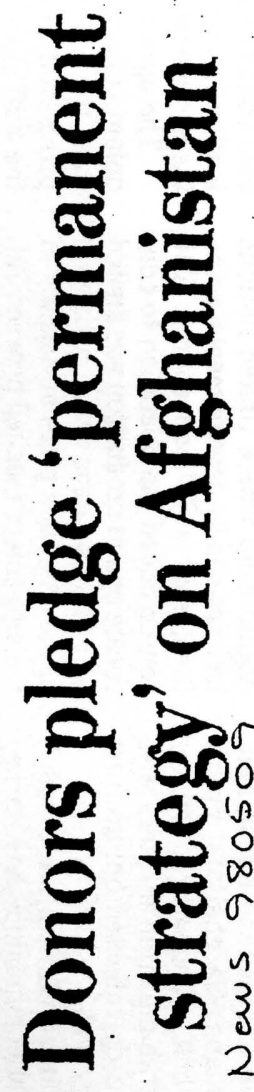

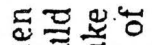

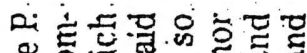

卷昰

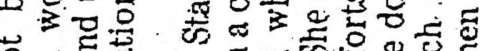

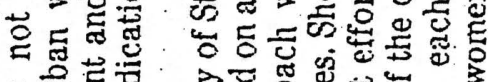

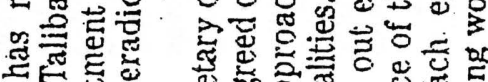

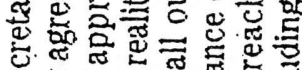

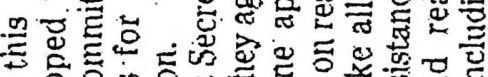

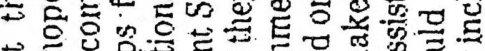

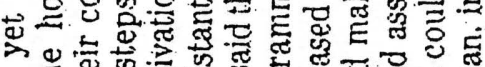

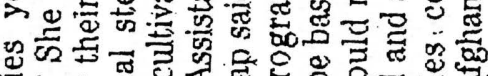

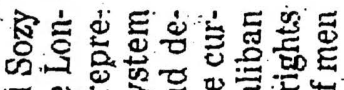

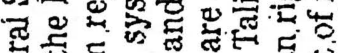

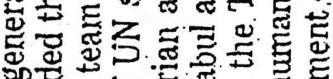

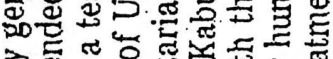

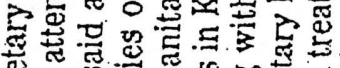

密。

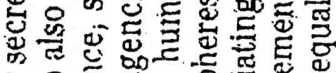

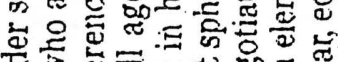

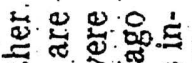

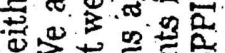

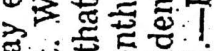

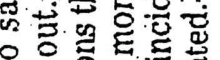

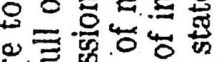

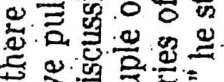

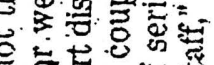

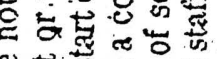

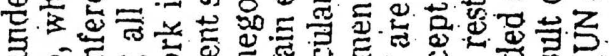

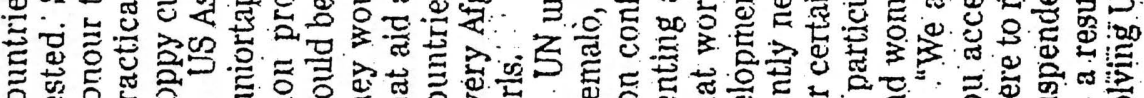

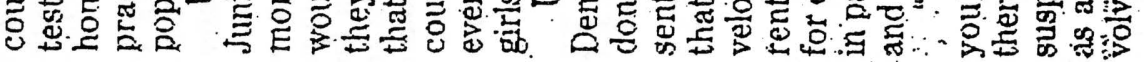

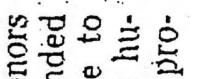

总芯菏哭

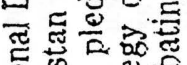

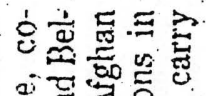

它总

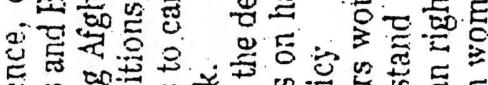

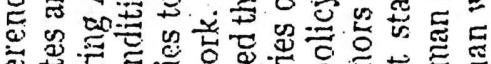

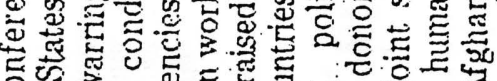

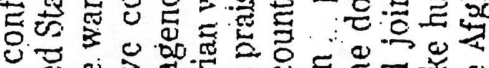

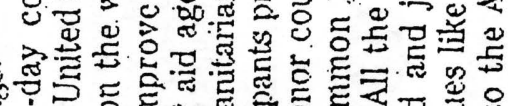

.

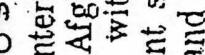

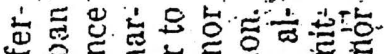

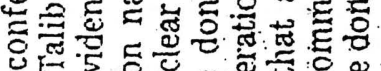

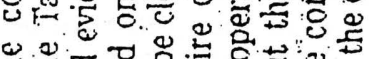

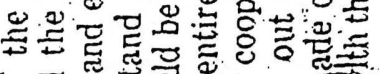

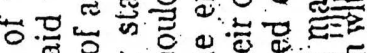

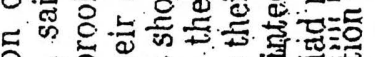

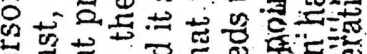

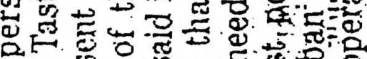

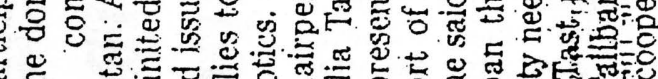

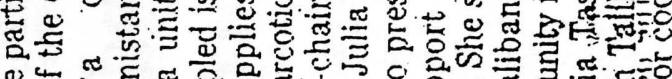

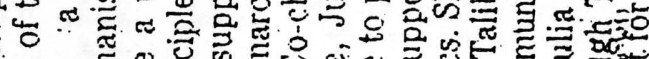

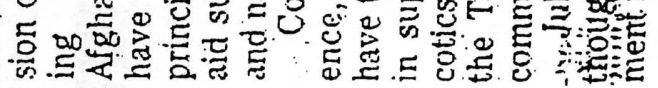
造造要
要要
官政
政

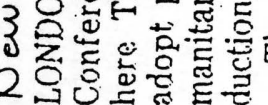

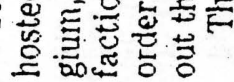

and take up the remaining items of the agenda.

He told newsmen that Taliban's side changed the composition of their delegation at the Steering Committee, and Abdul Hakeem Mlujahid, Afghan Ambassador to Paikistan, turned up for talks, with two other officials of the embassy.

The actual delegation which participated in the five-day talks from April 26 to 30 did not return from Kabul, on the ground that their presence is not necessary as the main issue of setting up Ulema Commission has already been agreed upon. Ngubi said this new' composition was not acceptable to the represcntative of Northern Alliance, and they refused to hold further consultations, what they said, at low-level. Northern Alliance delegation insisted that the issues of ceasefire, exchange of orisoners and lifting of blockade should be considered at the level of the Stecring Committee. Whereas, the Taliban side was of the view that these should be left for the Ulema Commission, which is authoritative and competent body to decide these important matters.

Abdul Hakeem Mujahid said they have suggested for holding of Ulems Commission' meeting on

May 6, either in Islamabad or Jalalabad. But, he said this propesal was not acceptable to the deiegates of Northern Alliance, who insisted for settling the dispute of lifting the biockade at the first stage, prior :o going ahead for iiema Commission.

He said they have already given a sacrifice by.accepting cquail representations of both the sides in the ilcma Commission, in spite of the iact that the Taliban are controlling

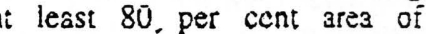
Afghanistan, and that the Northern Alliance is divided.

About lifting of bicckade. Mujahid said they have expressed tieir readiness to allow consignments of medicines to the blockaded area.

He said they tried to persuadi the Northern Alliance to decido date and venue for the convening of the Joint Ulema Commission as soon as possible so that substantive issues on agenda could be discussed but they did not concede to this point.

$\mathrm{Hc}$ further said the main ieaders like Hikmat Yar and Prof. Rasool Sayyaf were not represented at the Steering Committce's meeting from the opposite side, ever then, he added, they went for talks.

Asked whether the prior agree- 

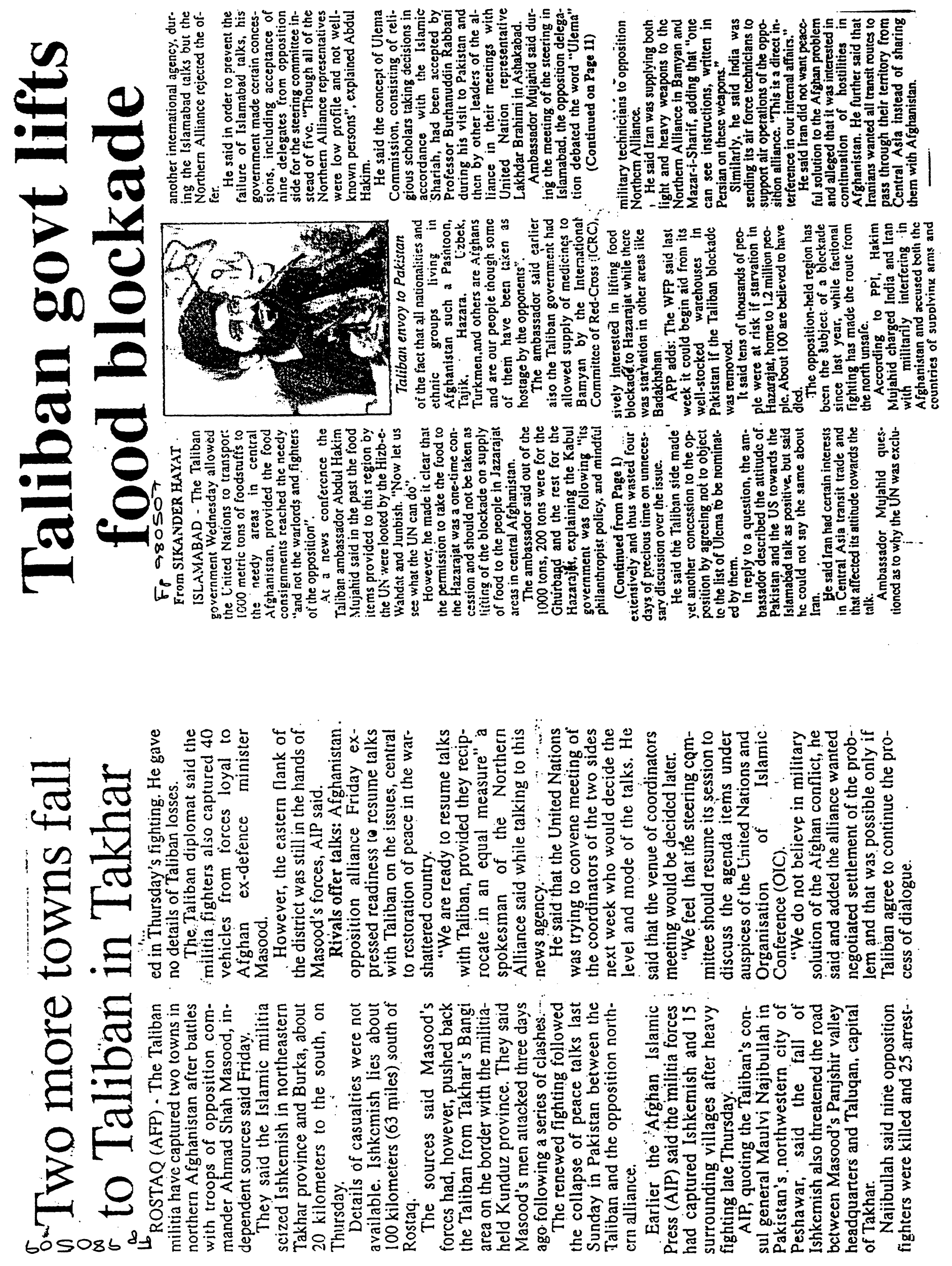

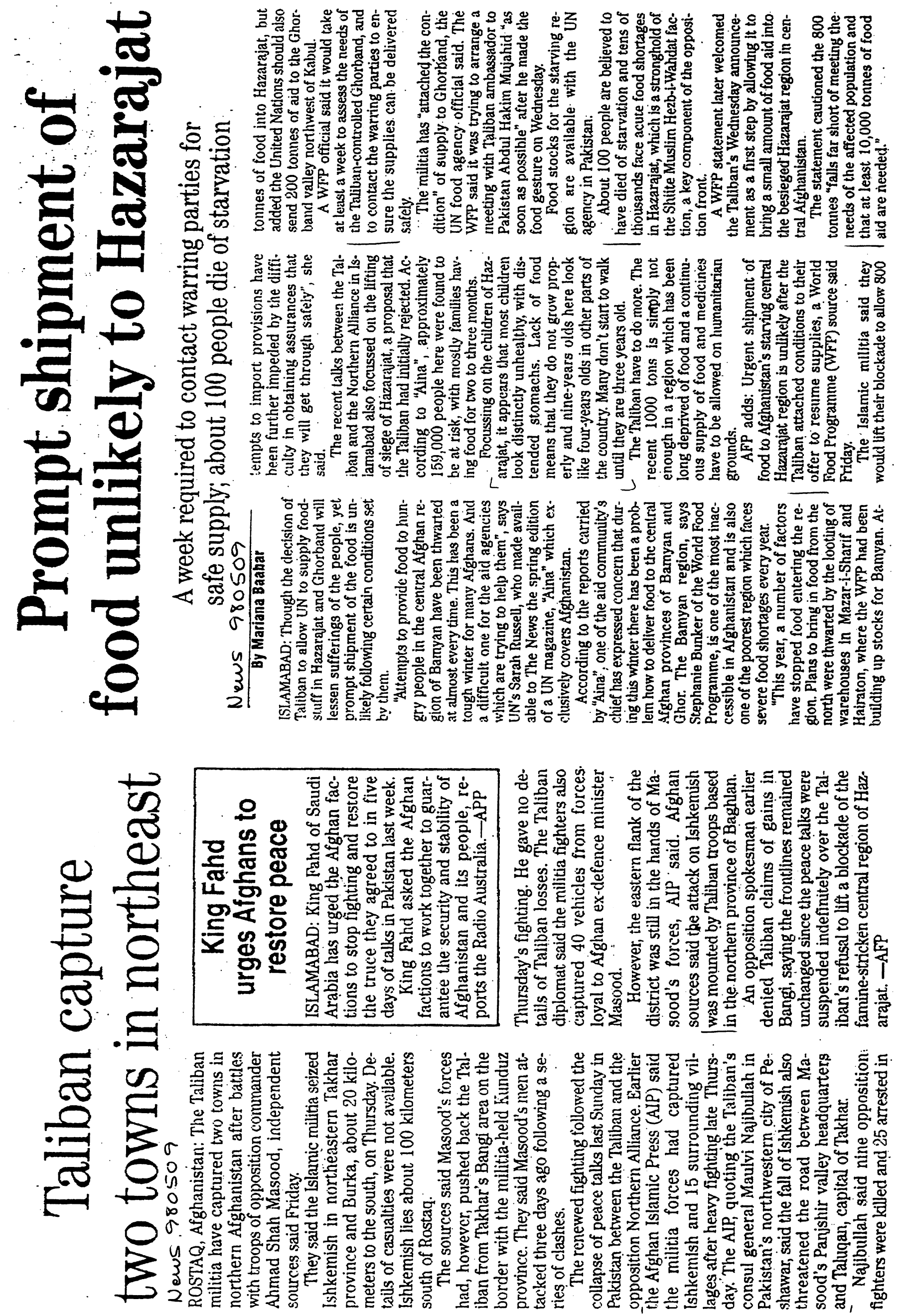


\section{Elusive Afghan peace}

\section{Rahimullah Yusufzai}

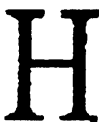

opes for peace are raised whenever the representatives of the warring $\mathbf{\Lambda}$ ghan fac. ions agrae to hold talkes. But those who have Ecen iollowing events in Aghanistan over the past two decades are hardly impressed. They know that the shrewd Afghans would never say no :o a mediator. or a wellivsher ljowever, making therr agree to solncthing that hams their interest is next to impossible.

The diplomats who brought the Taliban asd their opponents to the negotiating taile in lslamabad have reasons t) be cleased with their performance. US presidential envo; Bill Richardson, no doult piajed a cracial role in his ca pacity is the representative of the world's oniy superpower to convince the Talibon and the Northern Nlliance is hold iesie talks before the 20th annirersany of the comimunist coup d'etar on April $2 \%$ that triggered the ongoing conflict and oxposed the Afghan people (c) untold misertes. The groundwork for the Ifg-3n talks had already been done by the i:i and Pakistani diplomats. eien tikcugin their contribution has al. most veer. ignored by the media and all the creciit has instead sone to the Amcricans. The later took an unusual interest : $\mathrm{s}$ the taiks, onc intication of which :as the efforts by the US amhassado: in Islamabnd, Thomas Simmons $\mathrm{J}_{\mathrm{r}}$ is jreak the frequent deafdr tocks that-.-dogged the Afghas negoilaiss.

The it whan warlords have never reiused peace talks and their envojs have net eacis ather cren during the coursc of batsie. They have slign been amenabie to agreenentis on peace and power-sharing. That such asteements wicre never sully implemented explains the prediknment of the scores of peace. makers who have burnt their fingers while tring to promote peace and rec. onciliation in Afghaniatan. The fact that tite Isianabad talks were hold in a proper formal and inder the ausivices of the LXi and OIC was sort of a breakthrough The painful process of making the armed groups agree to the walks vas explained by the somewhat irreleunt curstiation of the steering comInittee, winch in turn was supposed to set the agencta and pave the way for the formation of the Llema Commission. In the end. the steering committee failed to achirve this objective because the Tajtiban kept insisting that all major isslles be iacklet by the Ulema Commission in accordance with the Shariah. Ironically, it was the Taliban leader. Hulla Mohammad Rabbani, who had !!mpasest : the setting uD of the stepring conmittee in the first placc. It wasn't possible to bypass the Taliban, who set most of the conditions for the talks and almost prevailed upon everyone that the Ulema Commission be cmprowered o ciecide all contcutions issues. $A s$ the most powertid afghan faction presently controlling almost 850 per cent of Afshanistan's territory, the Taliban are the key to any peaces settlement. Not long ago, the Rabbani government in Rabul called the shots and all other fac. tions were required to seek concessions from it. Former President Ptof Burhanuddin Rabbari and his Defence Minister Ahmad Shah Masood refused to concede much and had to pay the price by losing Kabul and most of their other possessions to the Taliban in

Though the Afghan talks
have collapsed and it
would take a while for
the mediators to
reassemble the two sides
in an attempt to resume
the peace process, it is
possible that the $40-$
member Ilema
Commission may
materialise eventually
materialise eventually

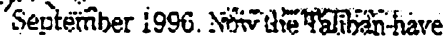
to make concessions and refusal on their past to concele anything to thelr despcrale inponents could galvanise all the other factions into a grand antiTuliban aliance.

The nucleus for the anti-Tatiban asliance is already there in the form of the Northern Alliancc. It inciudes Prof RabDerj's Jamiat.-i-Islann' Masood's Shurai-Niazar, Gen Abdul Rasheed Dostum's junbush-i-helli Islami, Karim Khalizi's Hezb-i.Wahdar, Shaikh Asef Kohseni's liarkat-i-Islami and Ustad Akbari's breakawry Hezb-i-Whahdat faction.

$\pi$ he Eastern Shura, led liy Haji Abdul Qadecr and comprising former mujahideen cominanders from Nangarhar, Kunnar and Laghmain provinces in eastern- Highanistan, has also joined the alliance and was represented in the recent Isiamabad talks by Maulana Abdul Hiadi Shinwarl, who, incidentally, also led the viorthern Alliance delegation. By giving representation to all the factions in its delegation, the anti-Tuliban alliance despite disunity in its okn ranks is now in a belter position to allrect other Afghian groups which were left out in the Is- lamabad talks. In fact, most of these groups were very critical of the orsan isers of the Islamabad talks for leaving thern out. In their mestings in Peshawar and elsewhere, theg argued that the US, IN, Pakistan and other mediators have succumbed to the pressure by the armed factions and left Afyshanistan and its hapless people at their mercy. They felt all significant Afghan groups ought to be irrviled in negotiations aimed at seltling the Aighan conflict.

That auy future negotiations between the Tatiban and their upponents would be long and tough is obvious in view of the frequent stalemates wit nessed during the steering committee meetings and the subsequent failure of the whole exercise. There wore deadlocks on the cefinition of the "Ulema" (religious schoiars) who are supposed to sit on the Ulisma Commission and on lifting of roard blockades to enable humanitarlan aid to reach needy popula tions in Afghanistan. The Taliban, after prolonged negotiations, backed down from their demand that only certified religinus scholans be named by both sides on tisc Iterna Commission. In lackt, they has a weak case as it is nore of their business to veto the names of delegaics prozksied by the rival side to take part in inc: :essotiations. It is up to the txo sides '? choose the Ulema of their choice

Moreovet, Li:e Ulema from the riva sides would srgue their own case 'whether thes mere graduates (ry) a certified simi usv or rot. The UTema are known to nculge in gruellives bates on potty religionss isstues for days and yet are unable to reach any definite conclusions. fre shudders to think what would be:omme of the parleys in the inema Cormission in case the : ti gious scholars nominated by the $\mathrm{Tal}$ iban and the Northern Alliance insist on their interpretzion of issues being de i)ated by them. Il such a scenerio, we rnay well reqitire referees who are well. versed in lslarric teaching to give their vertici on contertious issues and break the imnasse in the talks. In any case, the Afginan conflict is so old, complex and diversified in nature that Ulema alone carust he expected to resolve it to everyone's satisfaction As one Afghan policicil activist aptly remarked the issue was no longer a battle between "lilam ard Kufr" to be resolved by !Jem drasn from two rival sides.

Though the Afghan talks have collapsed and it roculd take a while for the mediators to iossemble the two sides in an attempt to resume the peace process, it is possible that the 40 -member Ulema Commission may materialise eventurilly. The seat stage would be to chnose a vertic 'o convene its finst sci. sion. Iran has cffered to host the com. mission's bist meeting and Palastan too would be keen to do so after having hosted the steering committee's talks in Islamabad

7 he Northern Alliance always had reservaticus about Pakistan's neutrality in the Afghan conflict and some of its component partes had objected to Islamabad playing host to the peace talks. Prof Rabbani hater said Islamabad could host the first round and the subsequent sessions could be heid in capitals of friendly countries and Afghanistan's neighbours. This explains that the anti-Taliban aljiance wouicin't want all the sessions to take place in Islamabad ouring to Palistan's tilt towards the Taliban. By the same yardistick, the Taliban may not agree to Iran as the venue for the kilks owing to Tehran's declared support for the antiTaliban forces. That would necessitate the need for firding other, and more ncutral venues for Afghan peace negotiations. It won't be easy to find many willing hosts for talks which scem endless and unproductive. Moreover, it is now common knowledge that armed groups in Afghinistan have found war to be a lucrative business and return of peace won't be a protitable proposition for them.

Many Afghass rould tell you that when their leaders talk, it is a sign that they are preparing for a new round of fighting. Afghans know their leaders well ard what they, are saying isn't wholl uniruc. fil this underscores the néed tor clinching a permahent cessefire among the Aighan combatants and convincing them to agree on other confidence-building measures, like exchangc of prisoners and lifting of road bluckiulus lu ailew humentarian assts. tance to reach ilte people. Only then would they be ab!e io discuss the more contentious polition issues like forma. tion of a broad-bssed government in Afghanistan.

Given the distrust that characterises the ties between the Taliban and their opponents, it won't be easy for them to set aside their orejudices and reach 3 sctulernent. It stiould also be kept in mind that the Taliban still believe they have the military capacity and popular support to inflict 3 defeat on their oppoinents and capare all of Afghanistan. Another perennial problem ls the foreign interference in Afghanistan's affairs. In such a situation, it would re. quire a Hercuiesn effort by the international community from the Uix and OIC platform to ensure that the sensclcss bloodletting in Afghanistan is stopped and a peaceful and democratic solution is found. By doing so, the worid woidd earn the abiding gratiture of the long-suffering Afghans. 


\section{Taliban, Massood forces}

\section{exchange fire in north \\ Nation 980510}

HOSSEIN KOT, Afghanistan (AFP) - Taliban forces and troops loyal to the ousted goveriment traded heavy shells and mortars on frontlines herc north of the militia-held capital Kabul Saturday. AFP witnessed.

Troops clashed on two fronts Saturday with heavy ground fighting for a strategic town of Ishkemish. sources said.

Taliban forces were fighting the trocps of Ahmad Shah Masood around the town, in the southivest of Takhar province which is controlled by the Jamiat-i-Islami, a major faction within the opposition alliance, officiai sources in the northeastern town of Rostak told AFP.

It was unclear who effectively controiled the strategic area, wherc northen alliance commander Masood is directing the fighting.

The Taliban are aiming to capture the lown and cut the road between the provincial capital Taloqan and Pul-i-Khumri, an important communications hub north of the Salang Tunnel.

"The town is being heavily disputed as it sits on the only usable supply rcute for Masood to Tajikistan in the north,' an analyst said.

'It is the only road available to Mfasood from the frontier in the north to Pul-i-Khumri, north of the Salang Tusnel and which is controlled by one of his allies,' he said.

The Taliban launched the attack Wednesday from the province of Kunduz. which borders Takhar to ine west and is the only northem province controiled by the Islamic militia, the sourc. es said.

The Talikan otherwise hold the southern two-thirds of the country.

On frontlines north of the Talibanheid capital Kabul the two sices trad. ed heavy shells and mortars, AFP witressed. Hardline Muslim militia commanders also asserted their readiress for a full-scale attack after iwo days which has seen arillery, recket and mortar fire but no change in positions only 25 kilometers noth of the capital.

'There has been some shelling since Friday moming but there hasn't been any change in the frontline, Taliban frontline commander Haji Mullah Ajodul Sattar said at his rear-line comnand post.

Both the Taliban and opposition troops continued to trade heavy fire throughout the day. but thexe have been no reports of any infantry ongagements or casualties.

Sattar said although Taliban forces - who have been deadlocked here for over eight months - were ready to attack forces of the ex-regime lcd by Masood, orders to attack had yet to come.

"We are hopeful to expand the fighting,' Sattar said. 'We have been ready to launch a big offensive for a long time but the leaders have been telling us to wait for the results of the talks."

Peace talks between the Taliban and the northem-based opposition alliarce broke down a week ago leaving most observers - and commanders here expecting mote fighting.

The opposition are barbaric so how can we, the military people, want peace,' Sattar said. 'No one will accept any deal where the Holy Quran and Shariat are not ruling.

The Taliban seized Kabul in September 1996, and have imposed what they say is the world's purest Islamic state on areas under their control.

The anti-Taliban alliance includes a collection of former arch-enemies, which came together when the Islamic militia attempted to extend their control into northem Afghadistan.

It includes the ex-government of president Burthanuddin Rabbani and Masood, ex-communist and ethnic-Urbek warlord Abdul Rashid Dostam and the Shia Hezb-iWahdat faction.

\section{United Nations rebuilding}

\section{quake-hit Afghanistan areas \\ News 980511}

ROSTAK: The United Nations and other humaritarian groups are facing a major task in rebuilding the earinquake-ravaged Rostak region of northern Afghanistan even as renewed fighting breaks out.

Not only must they rebuild thousands of homes but also. provide water, agricultural support and re-establish basic infrastructure in the villages, an official irom ACTED, a French non-governmental group, said Sunday.

The quake on February 4 , hit 14 villages in the region, almost wiping out six of them and leaving several thousand people dead.

In the tiny hamlet of Gharj, built on a mountainside at a height of more than 2,000 metres, around 800 people died when their houses were smashed by a landslide. "We are going to concentrate on the most damaged villages but that does not mean we are going to ignore the othets." explained Frekeric Roussel of
ACTED (Agence pour la Conperation Technique et le Development; Up to now aid agencies have been focusing on bringing in urgent supplies to help the survivors get through the bitter winter.

Bradley Foerster from the IN Development Programme estimates the value of the emergency aid at around 500,000 dollars. Foerster said he had a budget of two million collars, provided by donor countries after the quake, to bring help to ine region with the operation scheciuled to start in June. He estimated that only one million dollars would be needed to rebuild the villages.

ACTED estimated that overall sorne 2,500 houses vere destroyed as well as dorens of small bridges over mountain strcans. Official figures initially estimated the death tol at 4,000 but a survey in the affected villages subsequently put it at around 2,300 . Of the original 700 fartilies left homeless, only 290 still needed shelter two months later and now all have been housed in camps thrown up by the aid groups in the first days after the quake.

"There are actually more of them (in the camp) than before," said one aid worker, adding that poor families from other villages had come in hoping to get aid supplies.

But officials in the province of Takhar, which includes Rostak, have edilicistel the effurt, saying aid had been insufficient. Local commander Haji Sobanqul told AFP aid had been too little and had arrived very late. More than 2,400 families still need urgent help, he said, adding: "I'm waiting to see what sort of international aid will arrive to rehabilitate them."

The situation in the province has also worsened with renewed fight. ing. Taliban forces are battling the troops of Ahmad Shah Masud around the town of Isikamish in the southwest of Takhar province-AFP

\section{Fp 980510 Wheat export begins to $101^{5-}$ Afghanistan}

PESHAWAR (PPI) - Pakistan Sanirday dispatched 9000 metric tons of wheat to Afghänistan of the total 0.6 million metric tons the country has commitied to export to the brotherly neighbouring country for this year.

Abdul Satrar Lalika, Federal Minister for Food and Agriculture along Wieh Yousaf-Ayub Khan, NWFP Minister for Pood, Local Government and, $C$ \&.W inaugu. rated the ${ }_{i i}$ wheat dispatches to Afghanistan at Azakhel wheat re. serve centre.

8 The Afghan government trade commissioner received the first consignment while : Abdul Hakeem Mujahid Ambassador of Afghanistan to Pakistan, Afghan Counselor General and other concerred representatives of Afghan government were also present on this occasion.

He said that the decision to export wheat to Afghanistan was a realistic approach which would helo discouraging yarious anomalies which had been! involved in illegal transportation of wheat tour to Afghanistan.

He further said that keeping in view the centuries old trade, religious, cultural and traditional relations with Afghan Muslims the government of Pakistan ofiered to provide wheat to Afghanistan despite the fact that Pakistan-was facing the wheat deficic.

\section{Fp 980511} Taliban receive. major setback

ISLAMABAD (AFP) -.Troops loyal to Afghan opposition commander Ahmad Shah, Mascod launched a counter of fensive in northeastern Afghanistan Sunday and flushed out the Taliban militia from eight posts, Afghan Islamic Press (AIIP) reported.

The attack in Ishkemish in Takhar province was the fifth by Masood's troops since the Taliban Isiamic militia seized the area on Thursday and left 13 soldiers dead and 25 injured on both sides. it said.

-The : "Pakistan-based" private A fighan news service said the attack ws launchod from the town's eastem: side, which had remained in Masood's control, and both sides used heavy weapons in the fighting.

A Taliban spokesman quoted by AIP denied the opposition claim and said "our position in Ishkemish is very strong."

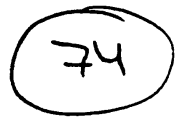




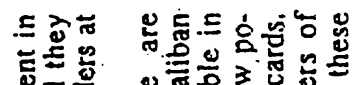

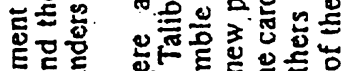

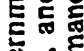

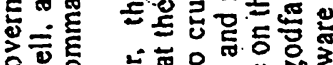

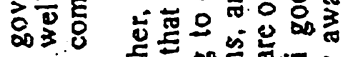

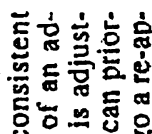

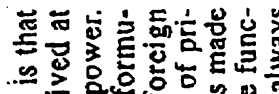

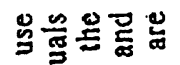

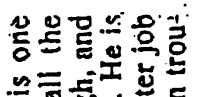

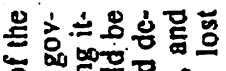

C

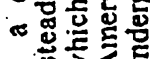

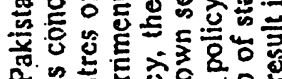

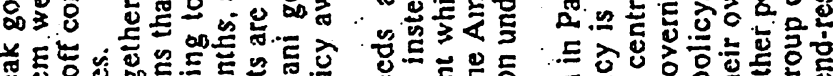

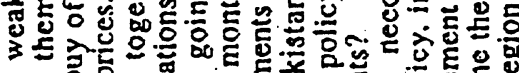

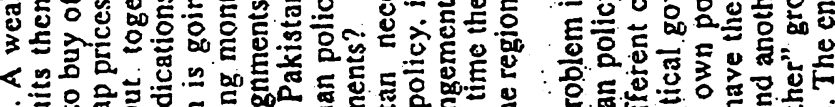

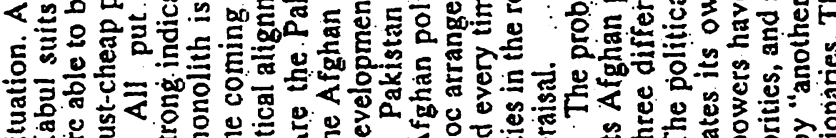

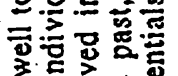

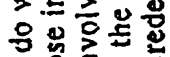

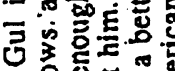

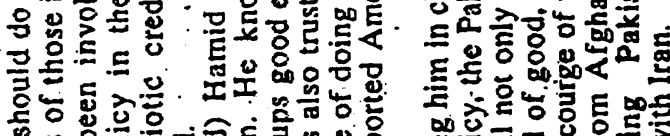

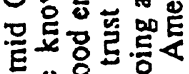

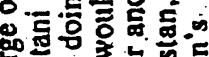

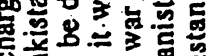

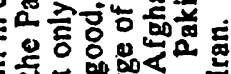

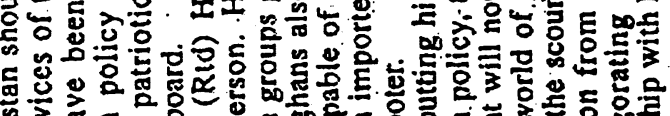

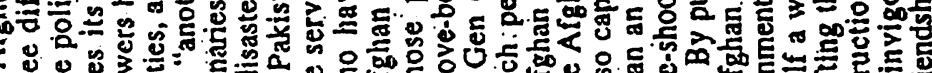

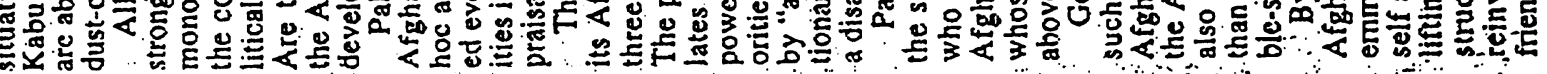

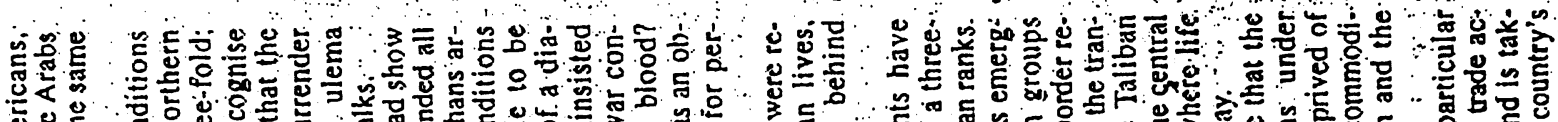

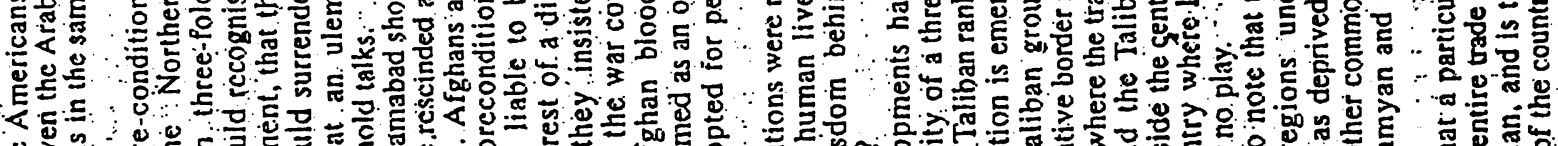

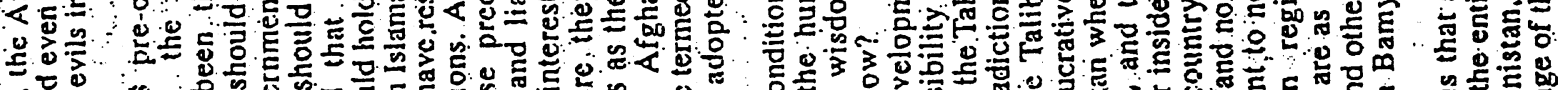

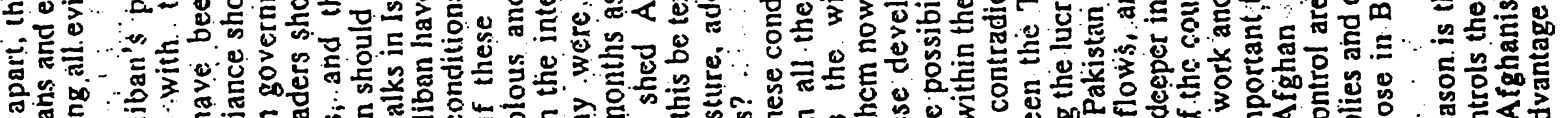

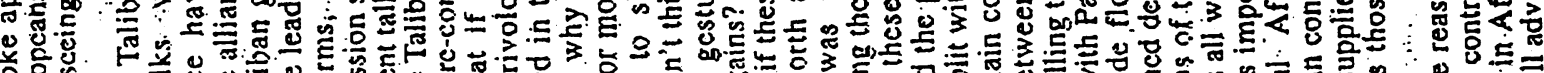

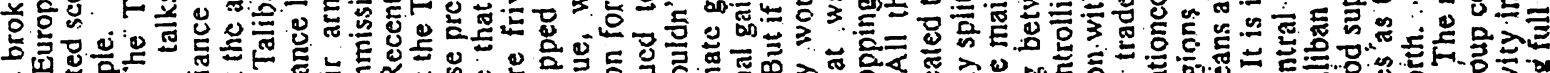

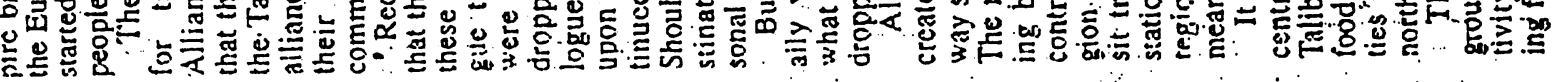

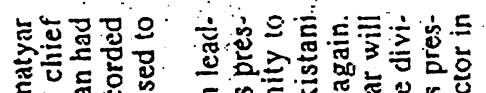

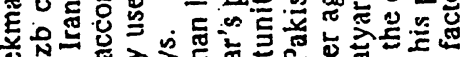

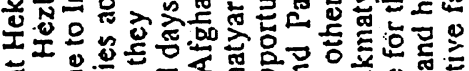

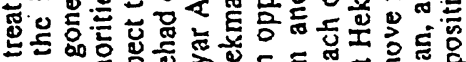

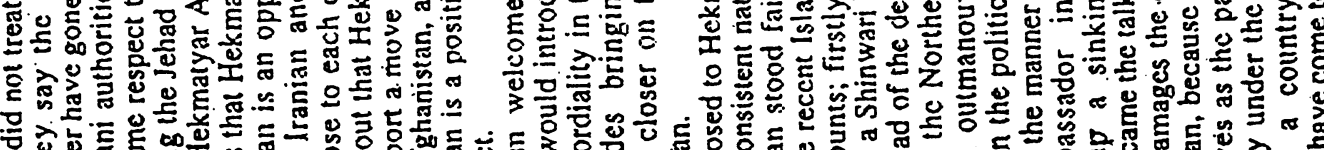

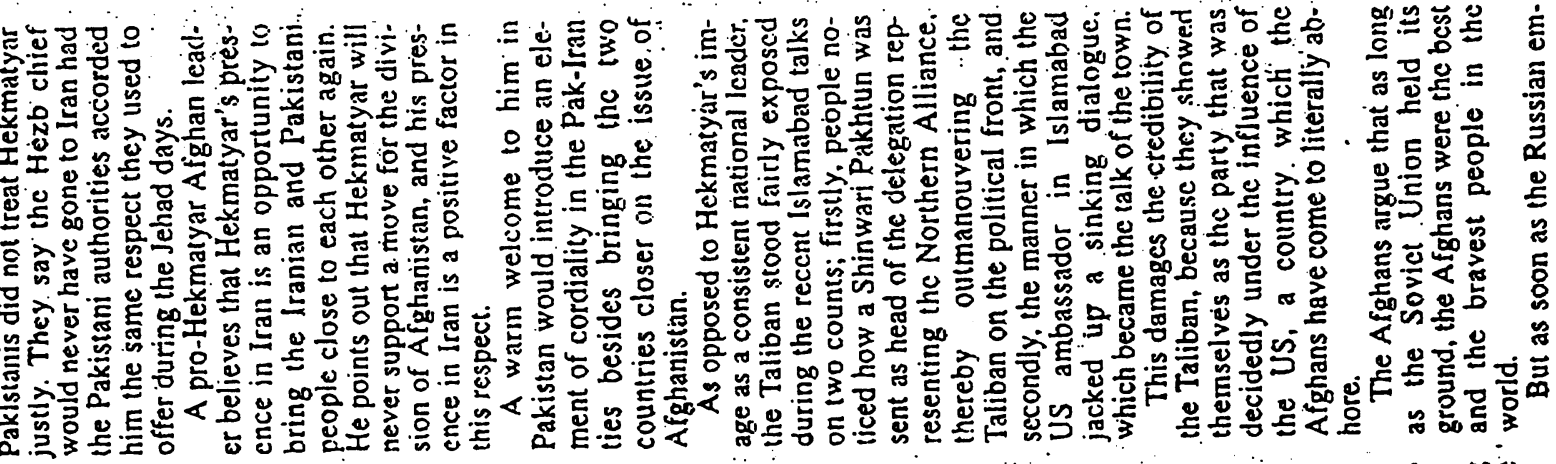

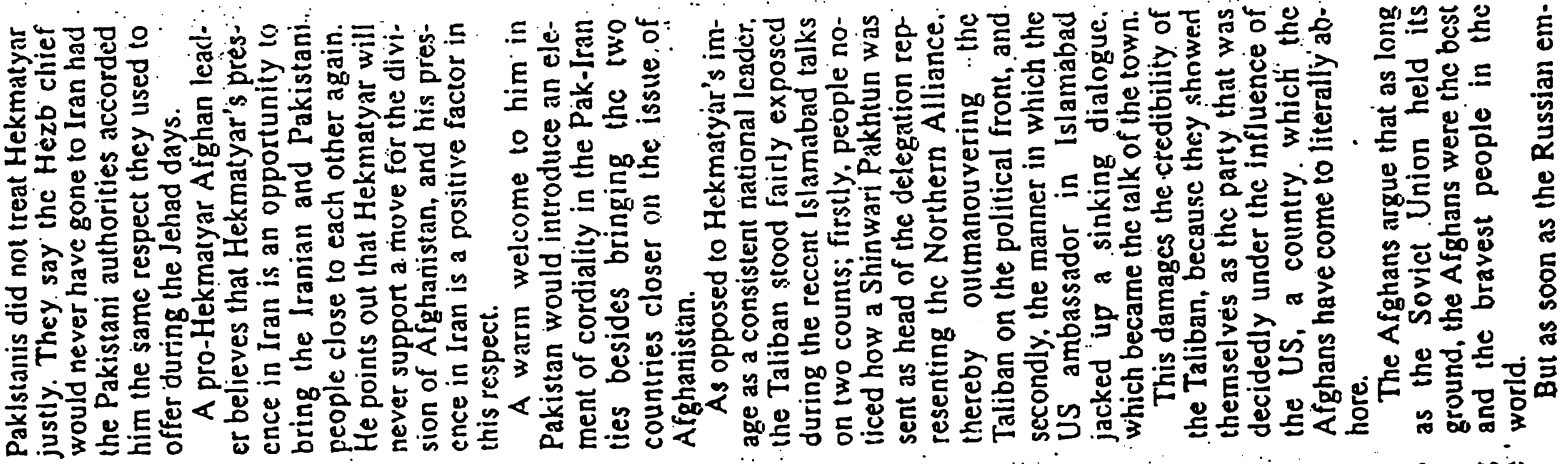

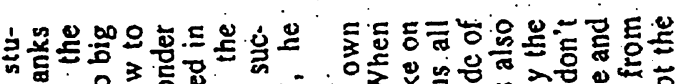

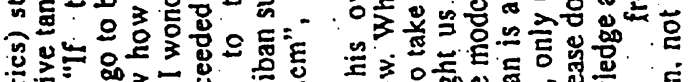

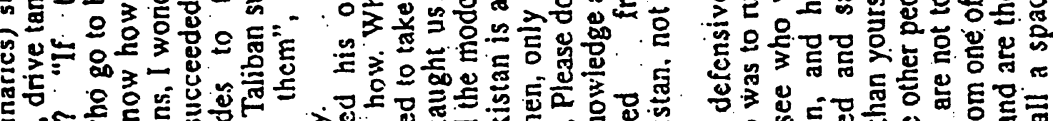

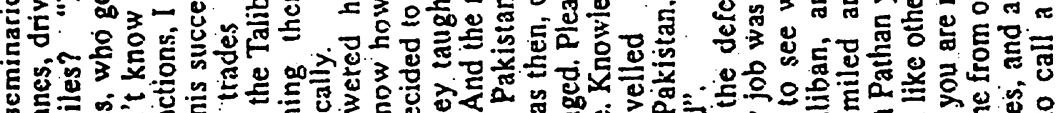

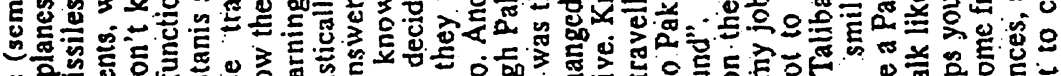

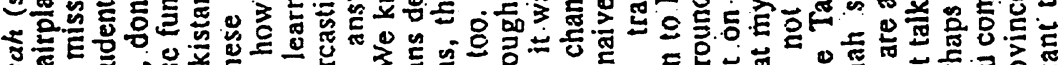

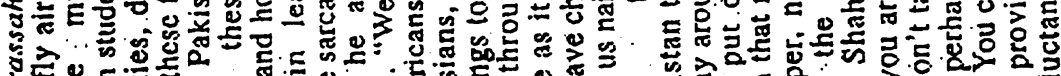

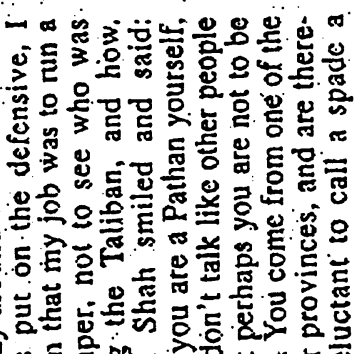

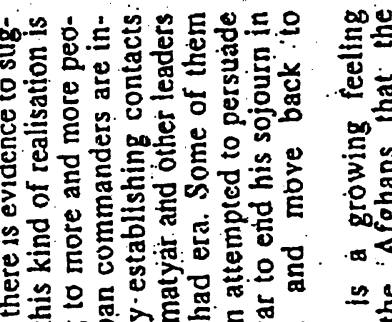

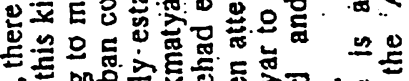
Q (2

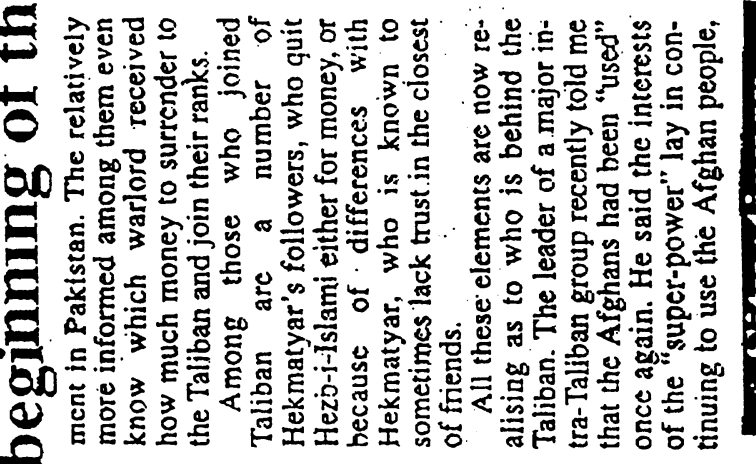

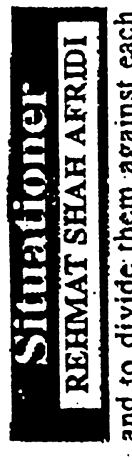

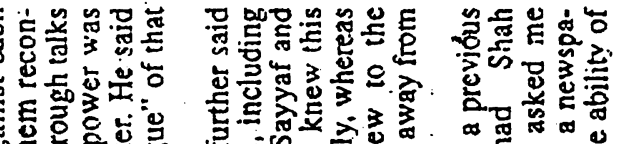

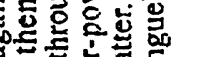

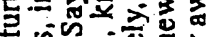

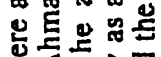

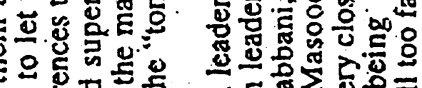

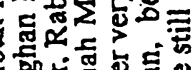
它密

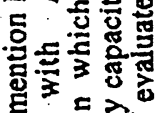

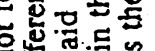

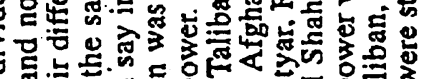
的罂

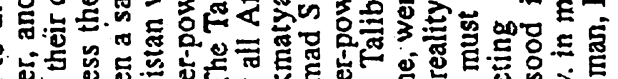

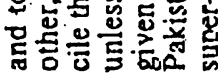

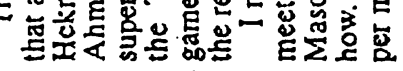

E.

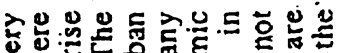

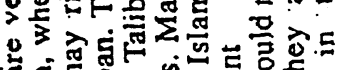
a ${ }^{2}$.

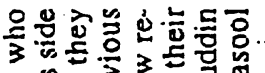
年

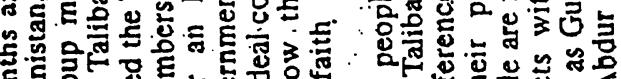

D

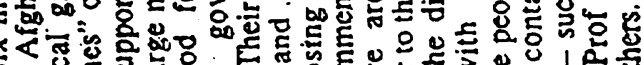

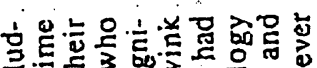

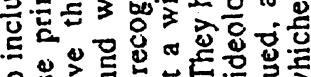

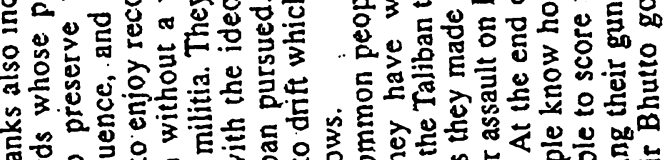

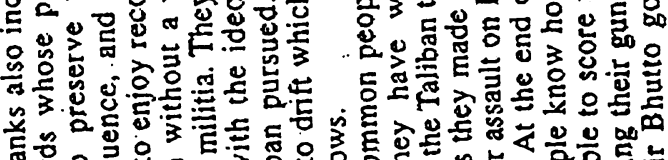

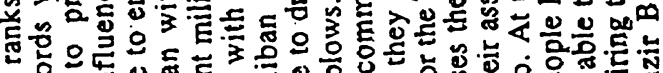

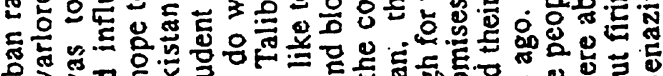

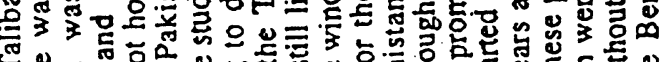

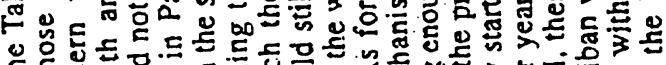

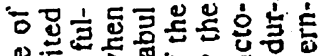

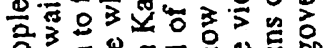
궁

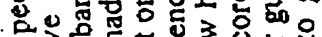
等

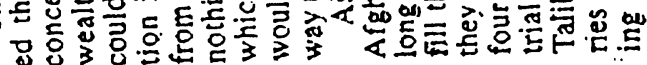




\section{UN team leaves Kabul 'pleased'}

KABUL (AFP) - A team of top United Nations officials left the Afghan capital Thursday pleased but without Taliban. concessions after 10 days of talks with officials aimed at resolving a series of dispules.

Delegation leader Martin Griffitbs - the New York-based deputy coordinator of the UN bumanitarian office - said the team had made 'great strides' in the talks sparked by a UN pull-out from southern Afghanistan.

The team were hoping to resolve four major stumbling blocks between the two sides, including UN staff security, working rights of Muslim expatriate women, a food blockade on opposition areas and access for women to work and education.

However the Taliban's planning minister, Kari Din Mohammad, Te. vealed in a joint press conference that the militia had made no new conces: sions.
'Regarding UN immunities, in the past the aid staff and the authorities bave always lived together without incident, and if anything has happened it has been unintentional and incidental,' Mohammad said.

In Manch the UN pulled out of the southern Taliban base of Kandahar following a series of assaults on expatriate staff by a senior militia official.

The minister asserted that women's access to bealth was "already there,' while access to education would be 'in line with Islamic law.' signalling no change in the militia's policy.

In areas held by the Taliban, women and girls are barred from education and working outside limited spheres within the health sector.

Both sides also announced that an other key dispute - over a Taliban ruling that foreign female Muslim staff of aid groups have to be accompanied by a male relative - had also not been resolved.

On this issue we could not reach an agreement, and have decided that scholars from the Islamic world will have to find a solution, 'the turbanned minister explained.

Concerning a Taliban aid blockade of the opposition-held and starvationhit region of Hazarajat, the minister announced that no new concessions had been made.

Early this week the Taliban announced that humanitarian aid would be allowed to enter the region, but a blockade on regular trade in and out of the Shiite Muslim area would remain in place.

Despite clearly failing to secure any Taliban policy change, Griffiths said the team were happy at the outcome of the talks.

He said although the talks had been 'hand work,' the team had made 'great strides.' Details of the contents of the 24-point agteement were not available.

'I leave here optimistic over our future relationship.' he concluded before leaving the slratiered capital.

However he said a decision over whether the UN would resume activities in Kandahar had not been taken and would be considered in the coming days by the UN secretary general

'We signed an agteement that we are very pleased yith and we hope we can continue improving the retationship between the UN and the authorities here. 'Griffiths said.

Despite holding two-thirds of the country including the capital $\mathrm{Ka}$ bul, the Taliban are not recognised as Aighanistan's legitimate government by the UN, and accuse the organisation of taking an anti-Taliban stance.

In particuiar, the Muslim mosement complain that the liN left Kandahar in a storm of protest and remained silent nver the complete looting of UN offices in the anti. Taliban stronghold of Mazar-iSharif last year.

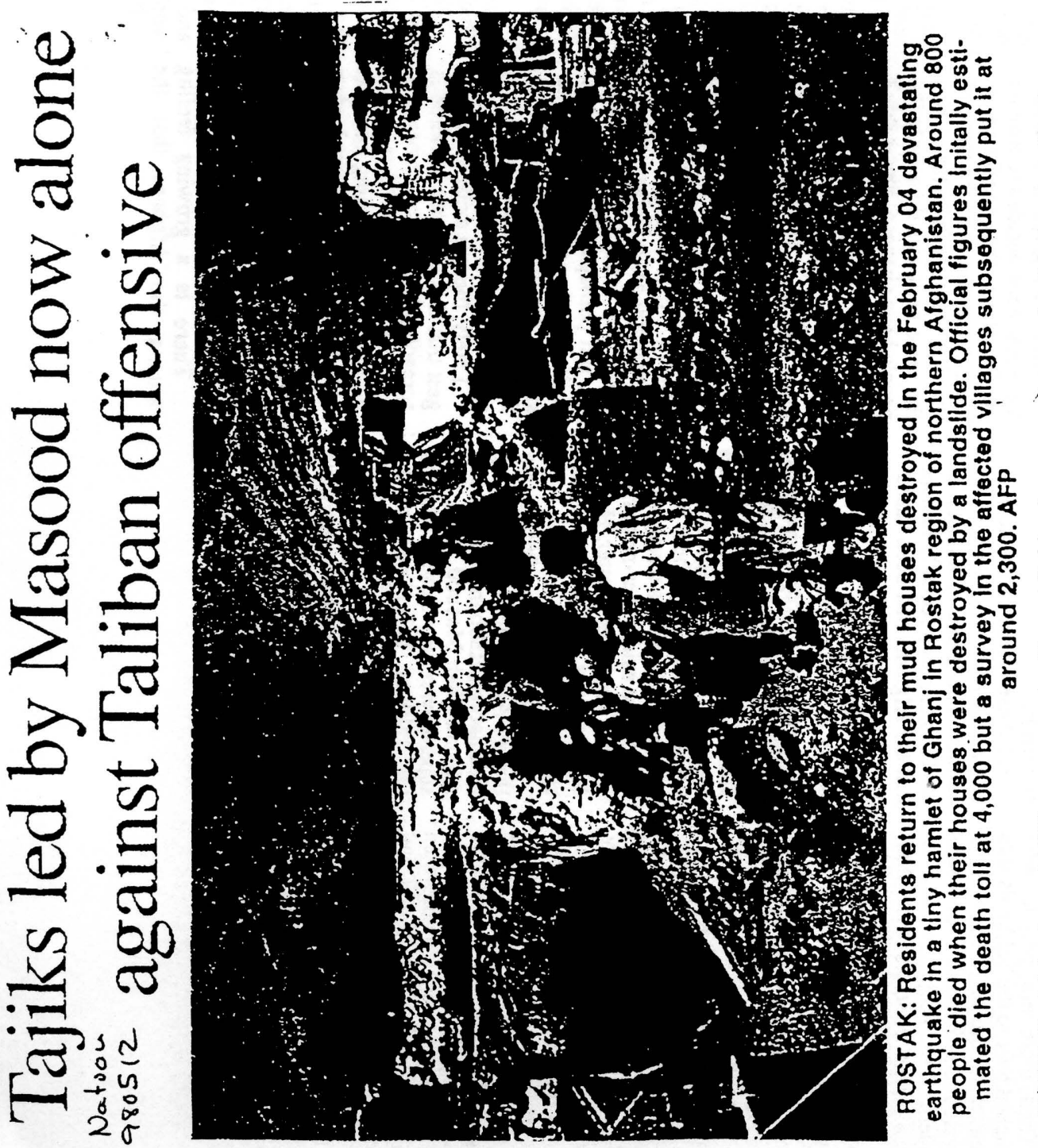

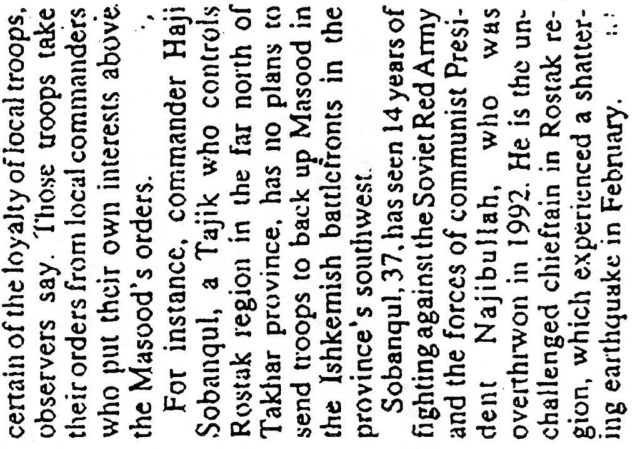

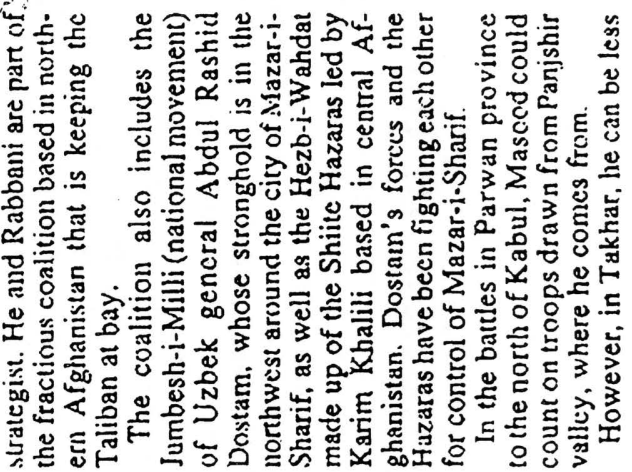

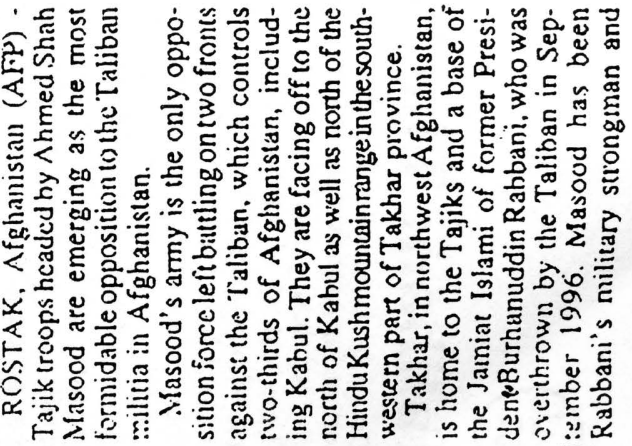




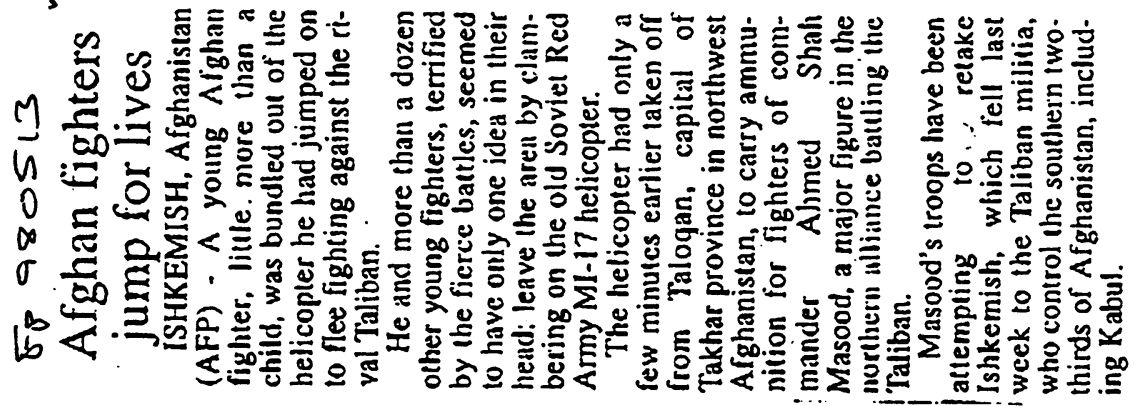

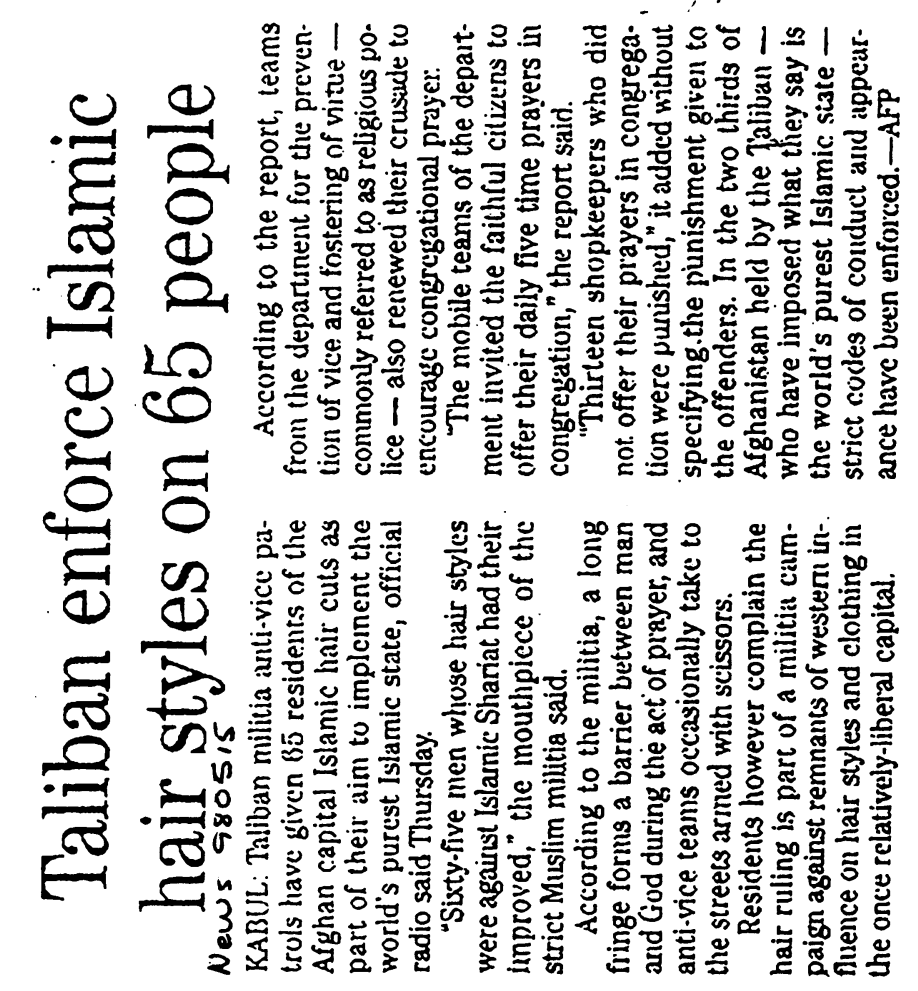

\section{0 killed as Taliban jets bomb Taloqan}

KABUL: Taliban jet fighters bombed a crowded market place in northern Afghanistan Sunday killing at least 30 people and wounding nearly 50 others, said a spokesman for opposition soldiers in the area.

The bomb slammed into the centre of Talogan, the provincial capital of Takhar province - the stronghold of ousted president Burhanuddin Rabbani, said Mohammed Arif, a spokesman for Rabbani.

Throughout Sunday Taliban jets screamed in low overhead in Taloqan.

At least four jets bombed the area, but the deadliest bomb landed smack in the middle of a food market where dozens of people were shopping, said Arif.

The Taliban-run Radio Shariat said Taliban jets bombed military installations belonging to the opposition in northern Afghanistan. The radio broadcast monitored Sunday did not say the bomb landed in a market.

Residents in Kabul, some 250 kilometres south of Taloqan said jet fighters roared out of the combined military and civilian airport throughout the day on Sunday heading towards northern Afghanistan.

Heavy fighting has been reported in northern Takhar province and in neighbouring Kunduz province.

The opposition claimed to have made some territorial gains in neighbouring Baghlan province, but that report could not be independently confirmed.

Arif said the opposition has contacted the United Nations and the Organisation of Islamic Conference to protest Sunday's bombing of Taloqan.

The $U N$ and the OIC jointly have been trying to get the warring factions to reach a negotiated settle. ment to end nearly two decades of bitter fighting.-AP
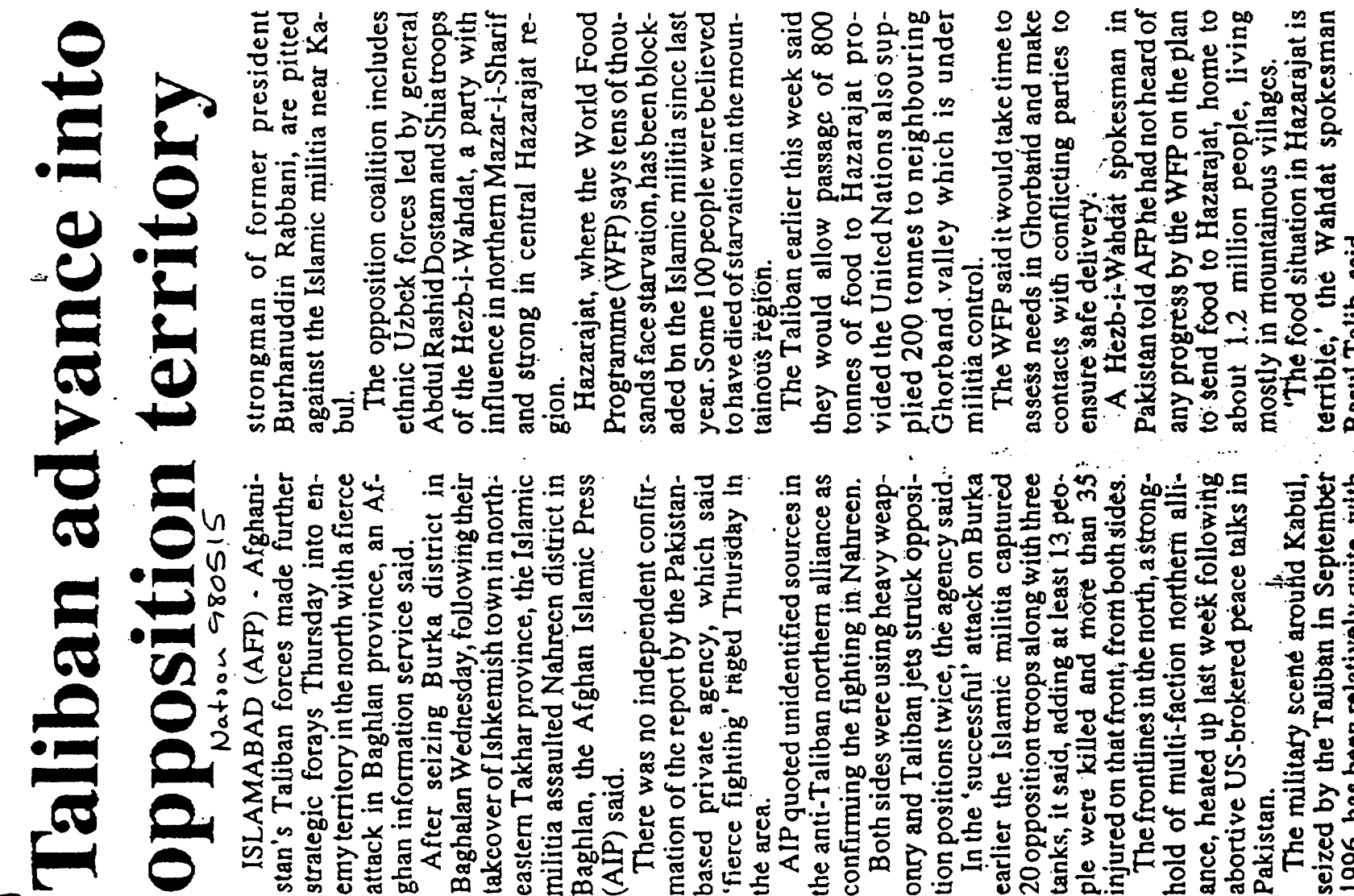

융녕흥

$\frac{c}{5}$

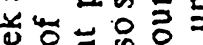

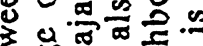

क

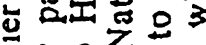

م무요.

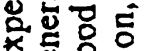

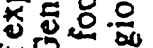
$\pm 0$

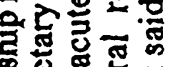

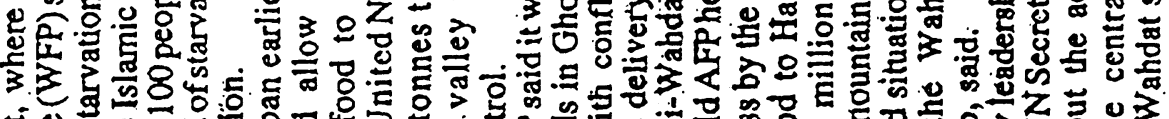

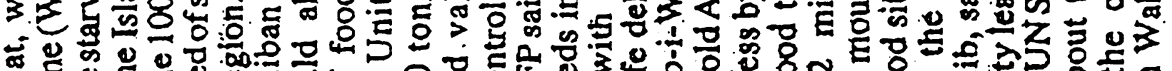

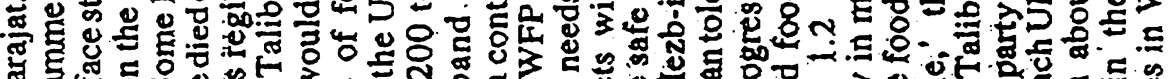

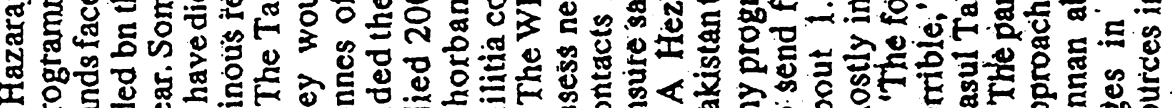

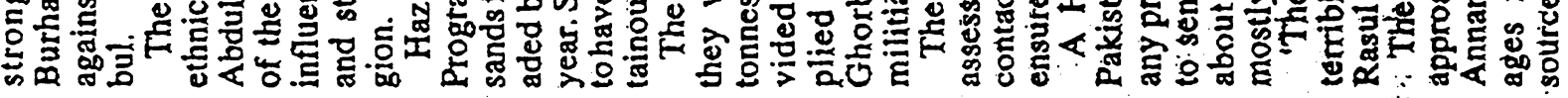

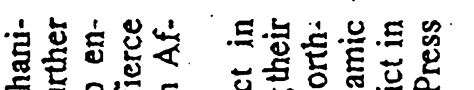

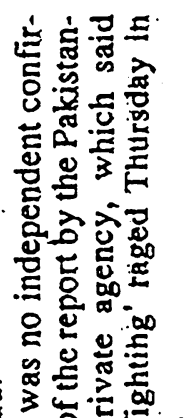

.

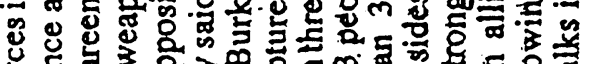

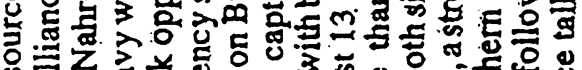

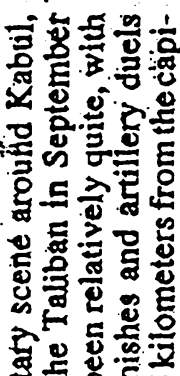

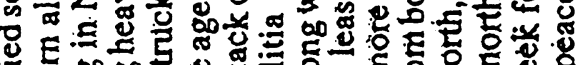

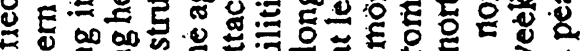

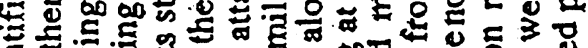
E

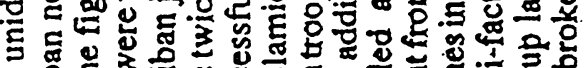

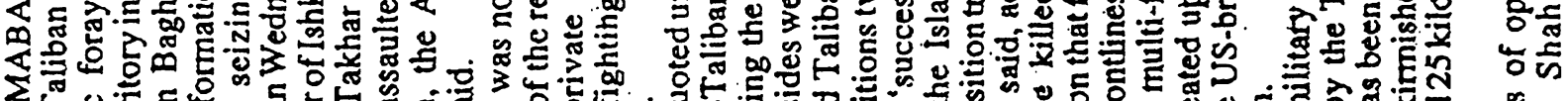

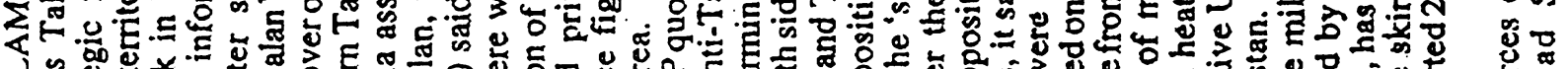

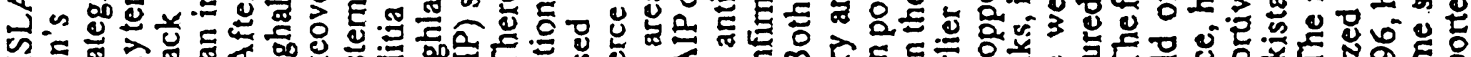

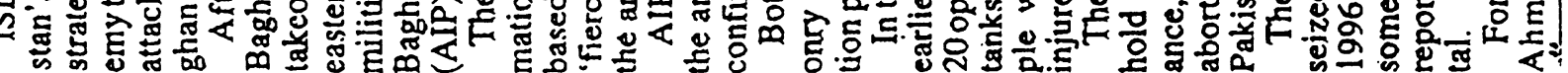




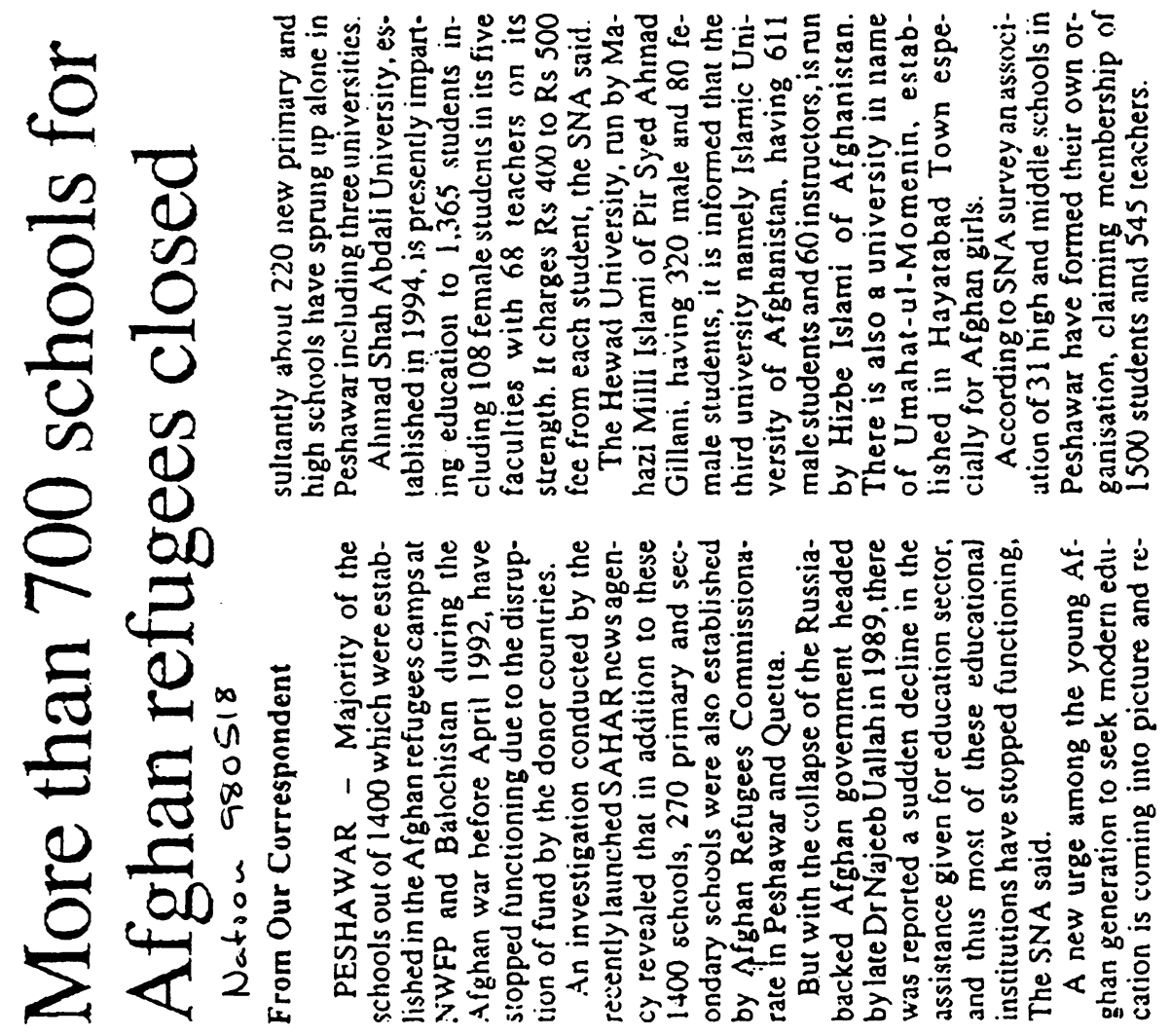

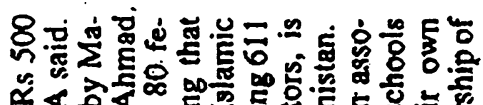

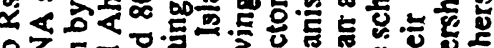

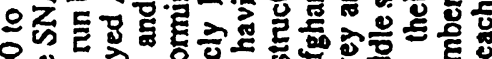

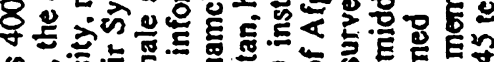

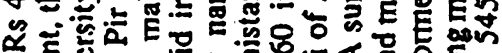

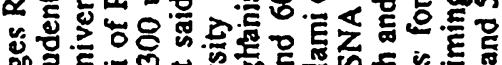

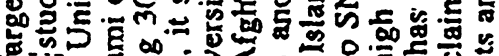

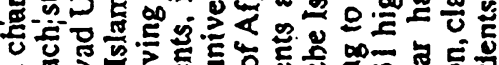

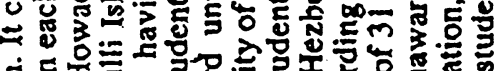

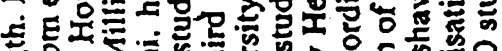

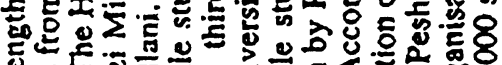

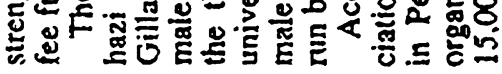

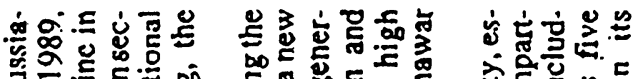

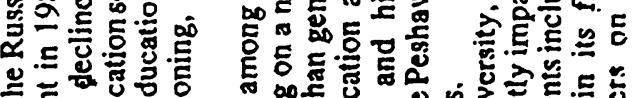

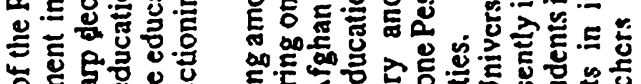

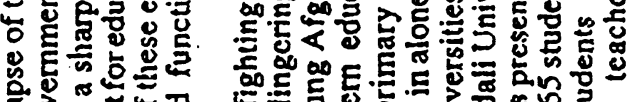

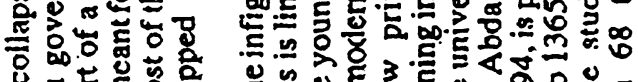

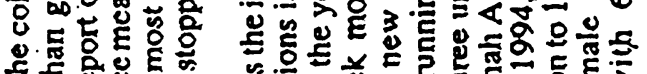

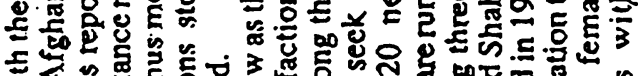

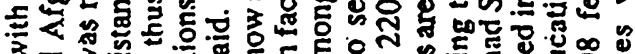

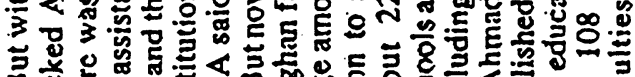

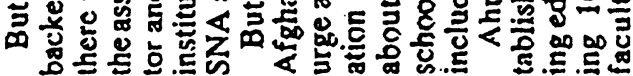

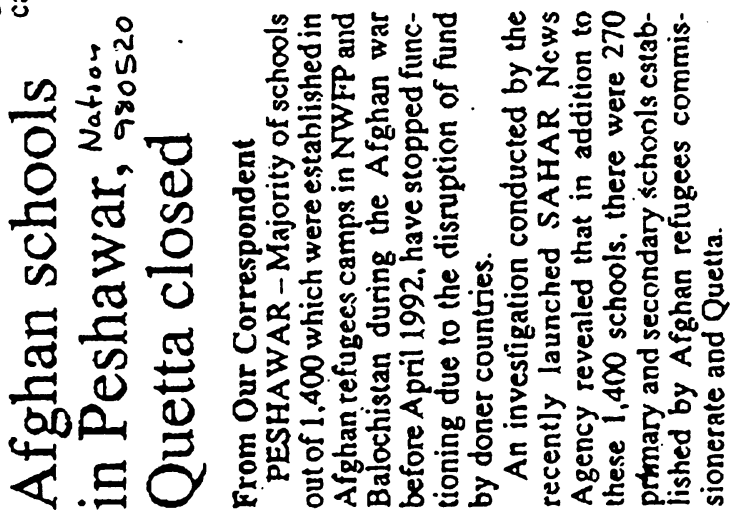

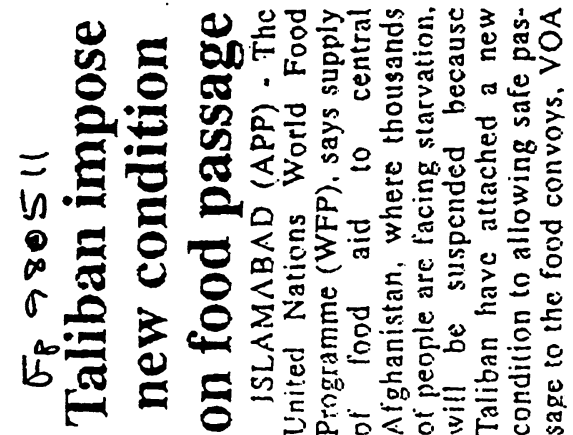

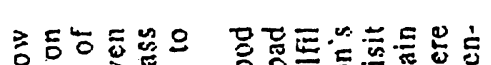

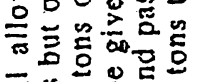
"

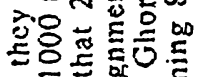

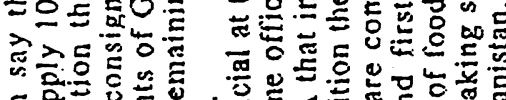

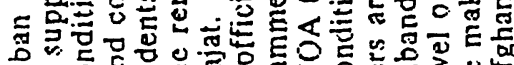

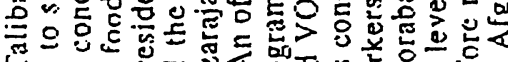

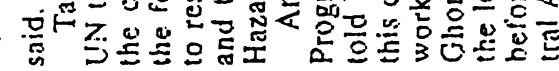
도문

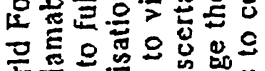

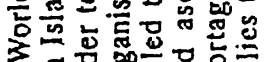

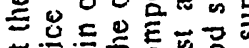

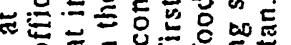

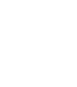

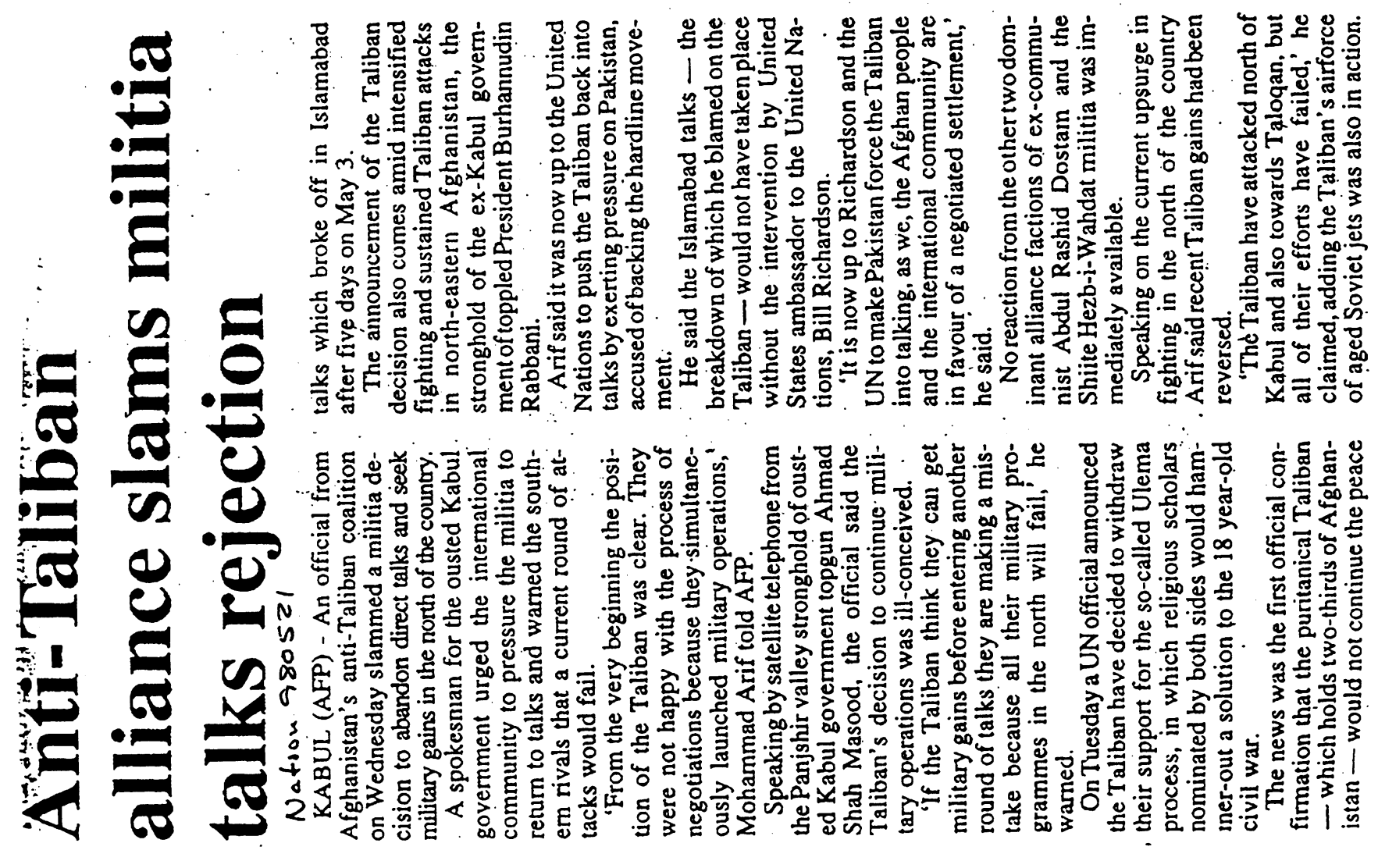




\section{$\bigcup_{980527}$ food convoy to cross Afghan frontlines}

KABUL (AFP) - United Nations irucks carrying food to faminc-hit central Afghanistan werc preparing Tuesday to test Taliban assurances that an aid blockade on rival areas was over. an official here said.

A World Food Programme Afghan opposition push Taliban out of two districts News 980526

\section{Tension again grips Mazar as Northern Alliance's internal rift widens}

K̇+BLR: Afghian opposition claimed to have captured two districts from the Taliban forces in Afghanistan's northern Kunduz province in their fresh offensive Monday.

Qalay $\mathrm{Zal}$ and Haq Tabeh districts have been captured and held despite a series of strong counter-attacks by Taliban soldiers trying to retake their former positions, said opposition spokesman Mohammed drif in a satellite telephone interview. Arif also said that 20 Taliban suidiers were kalled and $B O$ captured as well as a large quantity of heavy weapons and six tanks seized.

Both sides make inflated claims of success against each other. There was no independent confirmation of Arif's statements.

Recent weeks have seen fierce fighting in both the northwest of Afghanistan and on the frontline north of the capital Kabul.

Meanwhilc, sporadic clashes between two anti-Taliban alliance factions in their stronghold city of Mfazar-i-Sharif are threatening to engulf northern Afghanistan in a fresh round of chaos, sources said Monday:

With the shaky coalition unable to bury their differences and inca. pable of uniting to battle a recent round of Taliban attacks in the northeast, residents are leaving the dusty city.
"A lot of people are selling up their posscssions and leaving the city, while in the main bazaar around 80 per cent of the shops have closed up," an independent source told AFP.

There are factional checkposts all over Mazar-i-Sharif and a lot of people want to leave until the cycle of uncertainty and rising tension is broken," added another source, who wished to remain unidentified.

Diplomatic sources say the splits within the anti-Taliban alliance have spread following the failure of the two main rivals in Mazar.iSharif to relieve Taliban pressure on ex-gov. ernment topgun Ahmad Shah Masud. A succession of attacks by a northern enclave of purist Muslim militia support on Masud's Takhar province to the east has failed to mobilise either ex-communist warlord Abdul Rashid Dostam or the Shiite Hezb-i-Wahdat faction to the west.

"The alliance is now clearly demonstrating that even in the face of renewed Taliban ambitions to capture the north, they are too busy inghting among themselves," a West crn analyst based here commented.

The main dispute within the grouping is between a northern break-away group of Hezb-i-Wahdat and Dostam's ethnic-Uzbek Jumbesh faction over who should hold dominant power in Mazar-j.
Sharif. Once the exclusive realm of Dustam, a year of internal battles and failed Taliban assaults on Mazar i-Sharif has given the hardened Shiite street fighters dominance in the only city outside Taliban hands

Further tension has also emerged between Masud and other alliance members over the future of one-time prime minister and Masud's arch enemy Gulbuddin Hekmatyar, who heads the once-powerful Hezb-i-Is lami group.

Hekmatyar recently returned to Mazar-i-Sharif after a year in the political wilderness in exile in Iran sparking reports of shifting allegiances within the coalition.

While Dostam and Hezb-i-Wahdat have welcomed their one-time friend back, Masud continues to blame Hekmatyar for the fall of Kabul to the Taliban in September 1996 and his rocketing of the capital from 1992 to 1995.

The anti-Taliban alliance controls the northern one-third of Afghanistan, and comprises of Dostam, Hezb-i-Wahdat and the exKabul government of President Burhanuddin Rabbani.

The Taliban hold two-thirds of the country including the capital Kabul, and have vowed to bring peace, security and islam shariah to a country gripped by 18 years of war. -Agencies

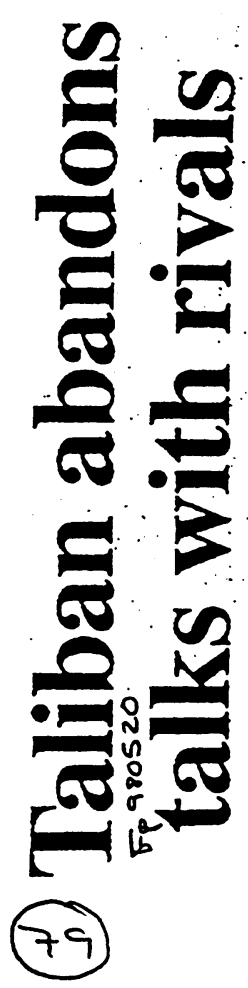

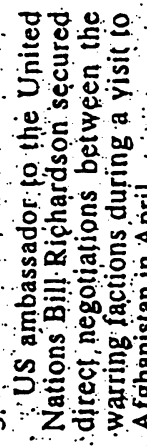
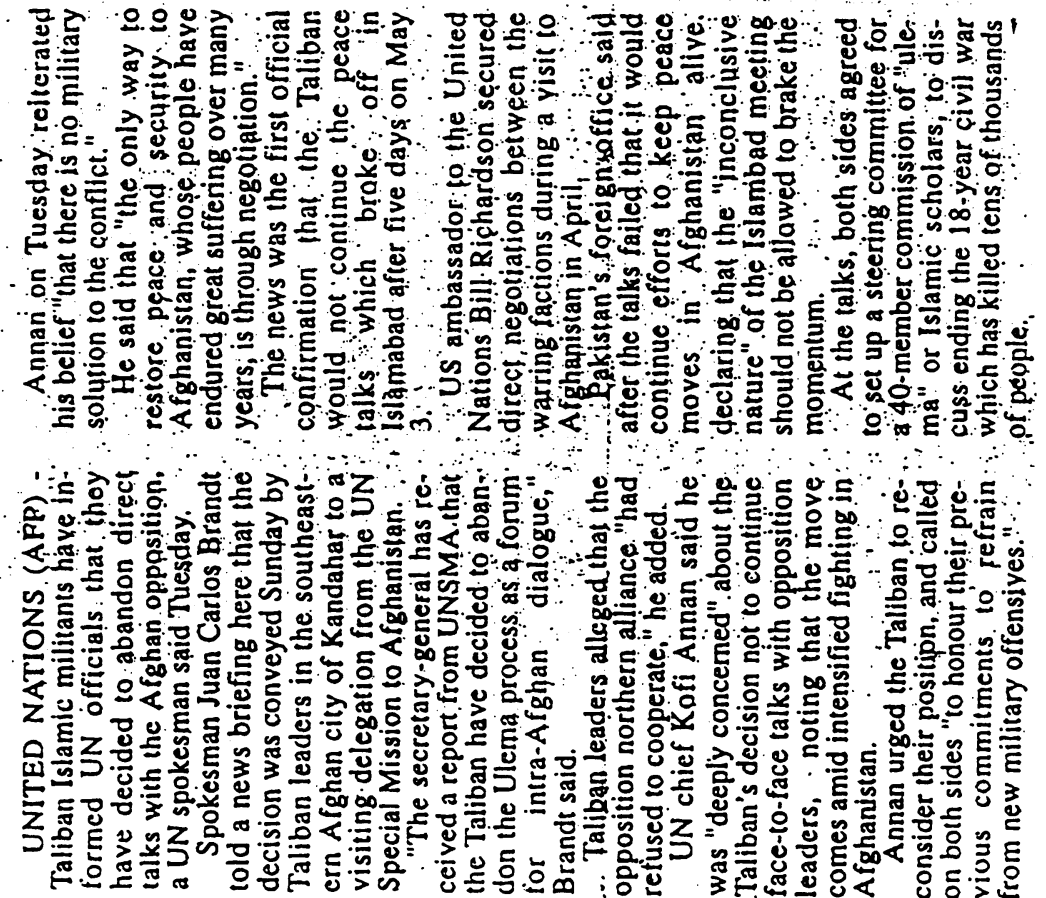

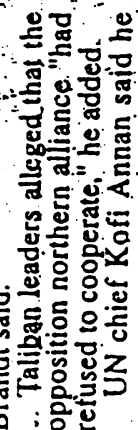

온 0.

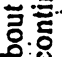

웡응
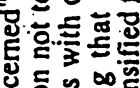

造

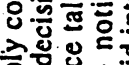

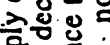

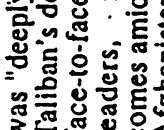

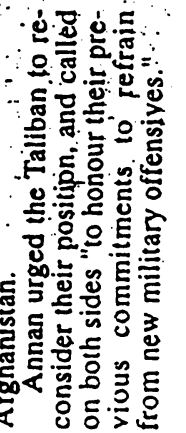

(WFP) official said the 40-iruck convoy carrying 600 tonnes of wheat to the Shiite Moslem-held Hazarajat was finalising proce. curcs for the first ovcrland aid delivery for months.

"On the weekend we reccived a lcter from the Taliban giving us permission to cross the frontlines," Kabul-based WFP official Amir Ibrahim told AFP.

He said the convoy had reached the town of Ghazni, 130 kilometers ( 80 milcs) south west of the Afghan capital, and a WFP official was in negoliations with the local Taliban govemer.

"We will show this letter at the tront and hopefully therc will be no problems,". Ibrahim said, adding that the convoy of trucks hoped to begin thcir attempt to cross on Wednesday.

The central Hazarajat -- considered the poorest rcgion of the wartorn country -- suffered a poor harvesi last ycar and a harsh winter which WFP says has thrown the region to the brink of starvation.

After a nine-month blockade, the Taliban agrced to allow 1.000 tonnes of wheal into Hazarajat earlier this month, on the condition that the UN proved that only civilians benefitted

from the aid.

Although the lack of aid reaching Shiite populated llazarajat has becn largely blamed on the Sunni Taliban. many aid workers considcr opposition troops $(0)$ be equally responsible for the food crisis.

. Nearly 4,000 metric connes of wheat earmarked for the area and storcd in northern Afghanistan was looted by opposition troops last September -- including a Shiile faction from Hazarajat -- in feed their ranks.

Widespread chaos and banditry throughout the north has made it impossible for foreign aid groups to transit the area to reach Hazarajat.

The Taliban accuse the UN of bias in causing an international furore over the militia's blockade, while remaining tight-lipped over the rampant looting and threats they suffered at the hands of the anti-Taliban alliance.

The militia assert that any commoditics allowed to entcr the area only serve to prop up opposition leaders, and the more crippling private trade blockade on the region remains in placc.

Whether the wheat is able to pass Taliban frontline chcckposts and cscapes loxting from the opposition will be closcly monitored by the UN, who hope to continue deliveries.

Two-thirds of Alghanistan, including the capital Kabul, is held by the Taliban, who have imposed what they say is the world's purist Islamic slate. 


\section{Poppy cultivation booms \\ By JUDDY Ep 980528

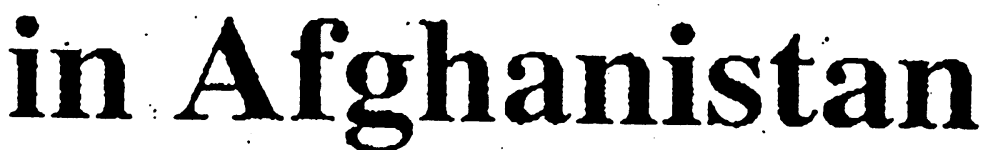

PESHAWAR - With an annual insrease rate of three per cent, in 1998 the standing poppy crop is covering over 40,000 lieclares in Afghainistan, according to official sources and figures collected from the US State Department's latest report issued in March last.

USG figure indicated an estimated three per cent increase in opium cultivation (in Afghaniston) from 37,950 hectares in 1996 to 39.150 hectares in 1997. This time round the area has crossed over in inver $\$ 0,000$ hectares. Whereas the crops yiclds increased by an estimated two per cent, from 1230 metric tons in 1996 to 1265 metric tuns in 1997". contains the report issued by the bureau of International narcotics and $\mathrm{b}$.aw Enforcement Affairs of USA's Siate Depastunche.

Accurding to the report, the crop's cultivation recorded increase (in 1997) in the Oruzgan and Kandhas provinces while in Nangarhar the area covered by poppy cultivation recorded oce. crease in 1997 as compared io the previous year.

However. Helmand and Nangarhar provinces remained the poppy dominated areas with sepanite production of 55 per cent and 19 pir cent, respectively. of the intal poppy crop. cultivaled in Afghanistan in 1997.

"There is no resuriction on pop. py crop's cultivation and transportation in the Taliban dominated areas of Afghanistan despite the declaration, issued last year. by the Taliban leaders thereby cultivalion and production of poppy opium had heen regarded un. Islamic.î said a bigh ranking official of the provincial government involved in government's activilies viz-a-viz poppy crop's elimination in the Federally Administered Tribul'Areus (FATA).

"Keeping in view the upward trend recorded during the last many years in Afghanistan, it is believed that this time round the puppy crop has been grown on over 40.000 hectares in the warravaged country.t said the official.

"Cultivation of poppy crop in Afghanistan, during 1998. is much more higher than previnus years in the light of incrense in its price and demand in the West, $\hat{i}$ said an official of the Peshawar-office of
USA's Narcotics Arfairs Sectionn.

The sowing season of poppy crop starts in August/Seplember. every year, with harvesting to get under way in May before its gum (the finished product used for heroin manufacturing) require an olher month to dry up before it is sold out to heroin laboratoly own. ers, according to an agriculturist of NAS.

"Afghunistan is the world's second largest opium producers. Its pxrous horders with Pakistan. Iran and Central Asian countries, combined with its rugged topography and an alscence of narcotics law cnforcement, make it one of the world's least controlled narcotics trafficking areas.

Nutnerous morphine base and heroin laboratories operale in Afghanistan, primarily in Kandhar and Nangarhar provinces along the Pakistani border.

Large quantities of precursor chemicals reportedly enter Afghanistan from Central Asia, Europe and India.î coniains the US report.

In this context the report main. laius further that $i$ heroin and morphine base flow out of Afghanistan into. Iran, the Central Asian Republics, Pakistan and India.

Some morphine basc transits bran en rsule (o) Turkey where it is refined into heroin, while other Afghan opiates enter Pakistan in North West Fronticr and Baluchistan provinces for sea shipment to Turkey via Makran Coast.

During 1997. there were indications of increased flow into. Central Asian republics.

About the role of Taliban and leaders of other. warting factions the US report maintains.

"During 1997, there were reports thut all warring factions in Afghoniston derived revenue from illicit dru's activity. There is evi. dence that the Taliban, which control much of Afghanistan, have made a policy decision to take advaritage of narcotics trafficking and production in order to pul pressure on the West and other consuming nations.

As the Taliban expanded their control over Afghanistan's opium growing territory, they appear to have expanded theis drug involvoment as well, including facilitating major traffickers to move large quantities of morphine base and heroin to the West".

It says further "the Toliban ad. mitted that, as a result of the Islamic tithing practice, called 'Usher'. lucal mullah receive 10 pet cent of the income carned by farmers, including opium farmers.

Opium is the leading cash crop; and a large percentage of the Taliban's taxes is from the profits of poppy production".

The report adds "there were re. liable reports, denied by the Tallban, that morphine basc and heruin laloratory operators paid a lax to some local Taliban officials and that a road tax was levied against the value of goods being transported, including illicit drugs.

There is no reliable information regarding drug-related comuption among Northem Alliance authorilies".

However, the Taliban ambassador to Islamabad, Maulvi Hakim Mujahid. in a recent interview to a Peshawar-based Urdu daily, rejected the impression created sgainst the Taliban's involvement in encouraging poppy cultivotion.

He said certain foreign countries had launched propaganda to defame the Taliban movement in Afgharistan:

If the UN or any of the donor agencies exient cosperation there would be no poppy crop after one ycas in Afghanistin, 1 the newspapar quoled the Afghan representotive as saying.

In October 1997, according to the report. the UNDCP proposed a comprehensive altcrnative deve! opmentpoppy reduction programme to be funded by its majur donor nations.

The ptojeet would target all poppy growing areas of Afghanistan. At an estimated cost of $\$ 2.5$ million a year for ten years, the programme's goal is to eliminate poppy cultivation entirely within that period.

"The project would begin with a small investment to test the authorities' political will to eradicate. if alternative development is successful, $\hat{\imath}$ contains the report. adding "USG counter narcolics objectives for Afghanistan include reduction and ultimate elimination of poppy and cannabis cultivation. denial of safe-haven to narcotics procesxing laboratories, and arrest conviction of couriers and traffickers in drugs and precursor chemicals". 

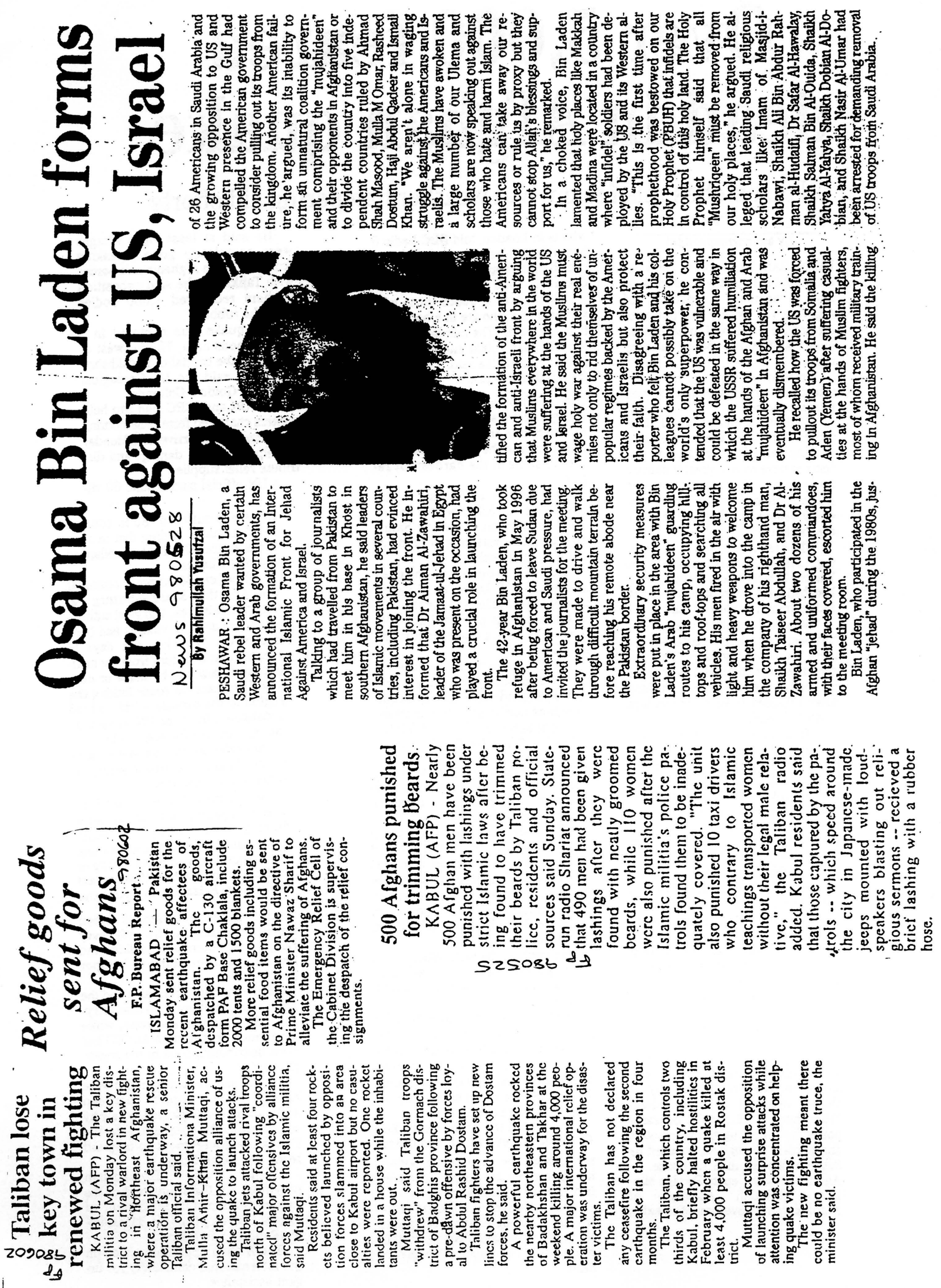


\section{Over 5,000 feared dead in Afghan quake}

\section{UN dispatches relief team; bad weather hampering aid efforts}

$$
\frac{\text { News } 980601}{\text { By our gerrespondent }}
$$

ISLAMABAD: Internationai aid workers scrambled Supday to reach a remote northern region of Afghanistan, where a powerful earthquake is believed to have killed more than 5,000 people on Saturday night.

Western aid workers in the af fected ares are saying that toll may increase further.

A LN assessment team that returned here from the area Sunday erening said: "the earthquake appears to have caused greater damage than the one that struck northern Afghanistan in February.". More than 4,000 people had died in the previ. ous earthquake.

"The destruction was quite amazing," said UN Coordinator Alfredo Witschi-Cestari after returning to Islamabad from the most seriously affected area of Shahir-i-Buzurg

"We saw a couple of villages that had been completely flattened, but there are probably more. This is a mountainous region, and the force of the earthquake sent houses crashing down hillsides towards the valleys below," he said.

Alfredo also flew over Rustag val. ley, where the damage appeared less

\begin{tabular}{|ll|}
\hline$\because \quad$ Photo on Pags 12 \\
\hline
\end{tabular}

severe. But the UN office in Islam. abad has received reports that the village of Dashtaq, near Rustaq, has been totally wiped out, kelling more than 1,000 people there.

"It is difficult at this stage to as. sess exactly how many have lost their lives, ${ }^{n}$ said Witschi-Cestari. "But it is clear that thousands are homeless."

Another report said there were at least 60,000 homeless people in the area. Half of them have lost their - homes. The rest are refusing to sleep

in their mudbrick homes fearing aftershocks.

Aid agencies are sending tents and blankets for temporary accommodation. The UN is already flying shelter material up to. Faizabad. From'there, it will have to be transported by helicopter to the remotest and hardest hit regions, wreaked by Saturday's magnitude 7.0 quake. Agencies add: Deputy Foreign Minister Abdullah Abdullah : of Afghanistan's government-in-exile who is in London, told BBC Radio 5 live, that the earthquake had killed over $5 ; 000$ people and he feared the death toll could go higher.

"Our worry is about those who survived and who are in a bad situs. tion," he said. "The number of dead is more than 5,000 and more than 1,000 injured," he said. "We expect the number will rise."

The UN office in Islamabad said it is trying to get planes into the region. As well efforts are being made to get a helicopter to the area for easier access to some of the hardest hit re gions.

The sources at Rostak in the quake zone said 3,000 people had already been buried following Saturday's temblor measuring around 7.0 on the Richter Scale.

According to the report, the dead included 3,000 killed in Shahre. Bizzurg, 1,900 killed in a settlement on the outskirts of Faizabad, 140 c.ildren killed in a school in Rostak, and 124 in Chaib.

The UN, meanwhile, released a statement putting the casualty toll from the second major earthquake in the remote northwest region in three months at between 2.000 and 3,000 .

The UN Office for the Coordina.

tion of Humanitarian Affairs (OCHA) said Sunday it would send a frvemember team to nortinern Afghanistan to help relief efforts.

The team will leave Zurich today to evaluate relief needs" in the quake zone, said Michael Elmquist from the OCHA Disaster Response Branch. They will be accompanied by a communications support team from the Swiss Disaster Relief Unit. he added.

Meanwhile, the International Red Cross got one plane into Faizabad on sunday and was preparing to set up a clinic in the area.

Hedge Kram, a spokesman for the Red Cross in Geneva, said the organisation officials in neighbouring Tajikistan were told by the Afghan ambassador that 5,000 people were killed. The Red Cross said it was not sble to confirm the figure.

Kram said the Afghanistan Red Crescent Society, which has offices throughout the earthquake region, has reported it has been able to confirm at least 1,500 dead.

From the area, a spokesman for the anti-Taliban alliance, Shamshul Haq Arianfar, said: "we need help desperately. Thousands of people are dead"
He said at least eight villages were completely gone. Speaking from Chaib, on Afghanistan's border with Tajikistan, he said opposition soldiers recovered 1,650 bodies from the rubble.

The quake was centered in a mountainous area, $72 \mathrm{kms}$ west of Faizabad, the capital of Badakhshan province, said the US Geological Survey in Golden. Coloracio.

The UN and ICRC said two heli. copters chartered from neighbouring Tajikistan should arrive here Monday to help assess the damage and distribute relief supplies.

A UN official said around 60 vil-

lages had sufiered " 80 to 100 per: cent" damage, adding that in some areas entire hillsides had collapsed, burying villages.

UN official Mohammad Asadullah told AFP that Shahr-e-Buzurg was the worst hit area, and local authorities there said $3 I$ villages had been destroyed. "It takes five days to reach Shahr-e-Buzurg from the near. est town Faizabad by horse or donkey. There are no roads linking the region to the outside world," added a statement from the UN humanitarian coordinator for Afghanistan.

Aid officials said survivors have started fleeing the area in search of water, sheiter and food.

Red Cross spokesman Juan Martinez told journalists that the most directly needed items are shelter, food, water and medicines, adding his organisation had flown $400 \mathrm{~kg}$ of medicine into Faizabad. However, aid workers in Faizabad Lold AFP the

weather in the mountainous region was deteriorating rapidfy, with heavy rain, flood, potential landslides and low clouds threatening to hamper aid efforts.

Medecins Sans Frontieres and the Red Cross said they were also ferrying aid to the stricken zone, while the French organisation ACTED has been distributing food in the region all Surday.

An aid source said agencies were hopeful the "border. between Afglianistan and Tajikistan, currently sealed, would be opened soon by the Dushanbe government to help aid reach the area quickty.

Takhar and Badakhshan provinces are the stronghold of the Jamiat-e-Islami (JD) movement of former Afghan president Burhanuddin Rabbani and Masood.

The Afghan opposition called on the international community for ur. gent assistance. 


\section{$\mathrm{N}$-tests source} of immense pride for Afghanistan

ISLAMABAD: The Islamic Emirate of Afghanistan Sunday said the successful nuclear tests of Pakistan is a mat. ter of "immense pleasure not only for islamabad, but entire Islamic worid."

"On the one hand, it helps preserve balance of power in the region and on the other, it will prevent ene mies of Islam to dare implement their ill-intentions and evil designs against Islamic world," a statement by the Afghan Ministry of Foreign Affairs said.

\section{Nows 98060}

Since pollcy of Afghanistan is against nuclear proliferation in the region, it advised Pakistan to practise restraint in conducting nuclear tests, though it enjoyed the right to retaliate Indian nuclear testing.

But as the international community and other interested international organisations failed to strongly condemn the conduct of India and take effective penalty measures, it forced Pakistan to test its own devices to en sure its national security and interests, and to restore the strategic balance in the region" said the stattithent, released. by thes ifghin embassy in Islamabad.-PPI
Taliban publicly

News Bureau Roport 980603 PESHAWAR: For the first time the Taliban in eastern Afghan province of Nangarhar publicly burnt 1893 kilograms of opium on Monday to show their commitment to fight drugs.

The opium, according to Taliban officials, was collected from Afghan farmers who cultivated poppy in areas in Nangarhar and Laghman provinces where it wasn't sown earlier. Among others, the burning of opium was watched by UNDCP's Gary Lewis, diplomats from Pakistan and Iran based in the provincial capital Jalalabad and Taliban government officials.

Abdul Hamid Akhundzada, head of the Afghan anti-narcotics departdestroy opium

ment, told the Sahar News Agency that the opium was surrendered vol. untarily to the Taliban in the two provinces. Nangarhar Governor, Mullah Abdul Kabir, told newsmen that his government was ready to cooperate with the UN and other donors to eradicate poppy cultiva tion provided alternate sources of livelihood were provided to the Afghans and development activities are sponsored.

The burning of opium took place at Farm Hadda near Jalalabad. Local UNDCP officials estimated that the burnt opium was worth Pak Rs $5 \mathrm{mil}-$ lion. It was learnt that farmers from whom the opium was collected weren't compensated for this loss, which otherwise sell the same in private to make money.

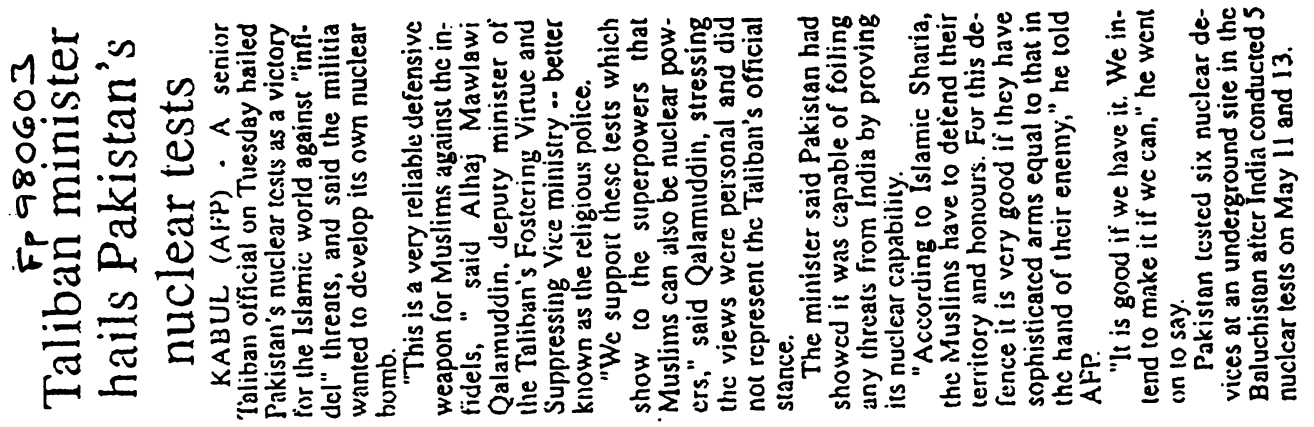

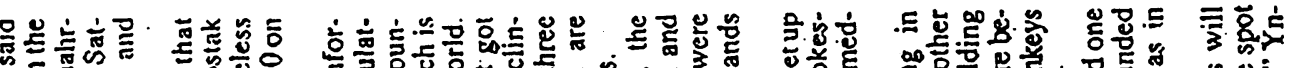

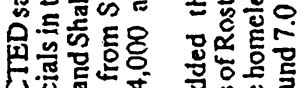

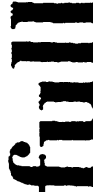

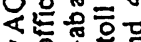
은

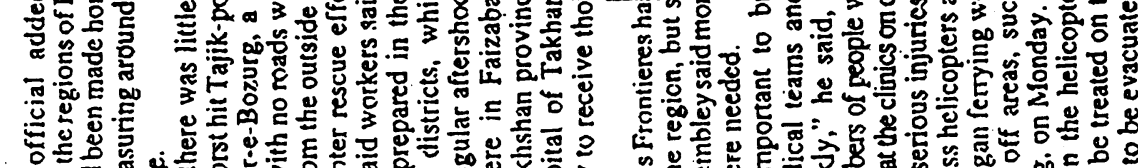

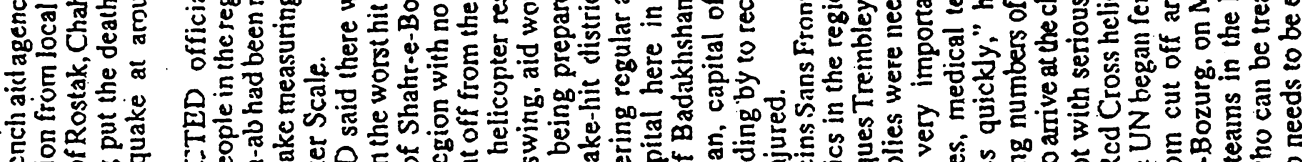

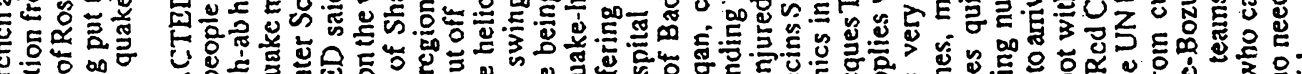

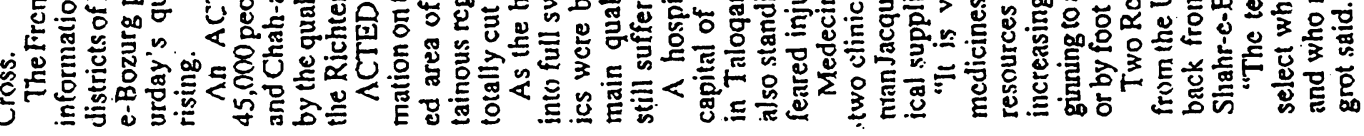

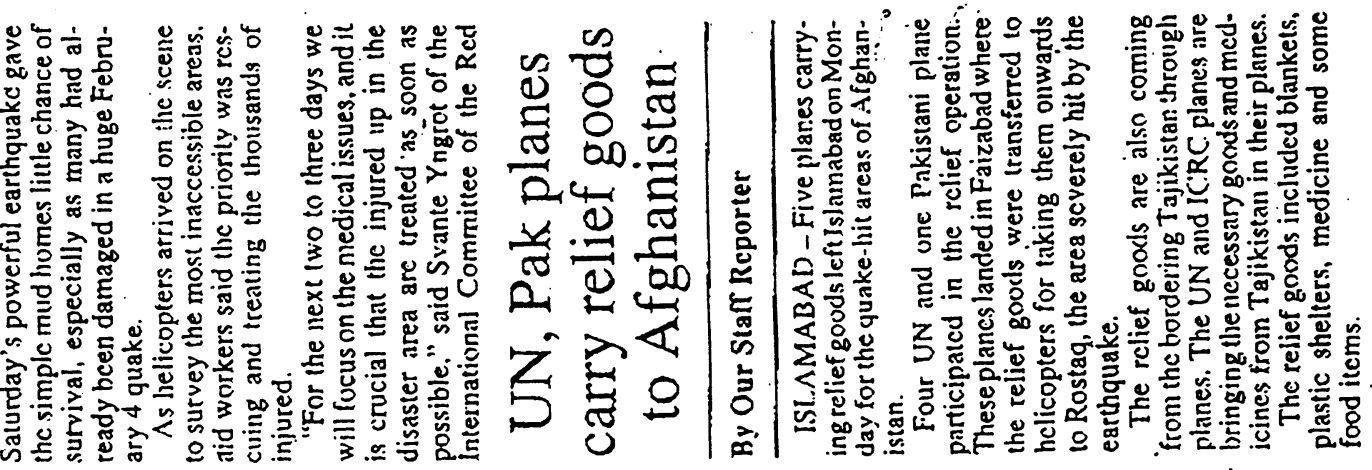

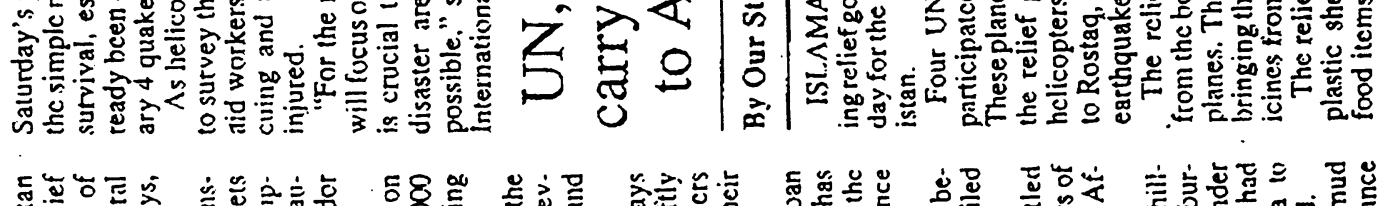

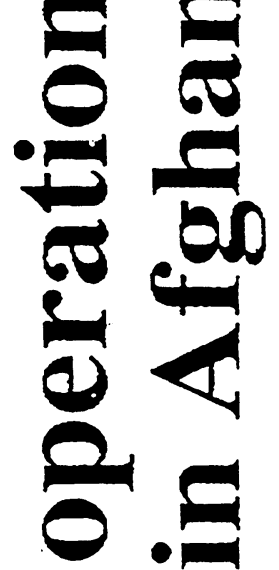

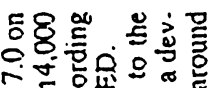

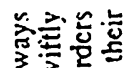

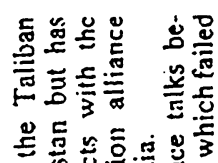

额范定

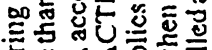

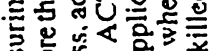

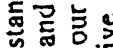

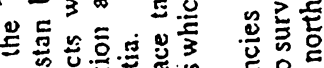

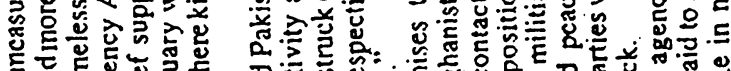

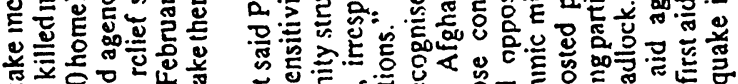

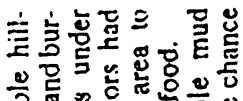
要, ¿

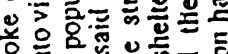

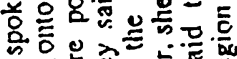

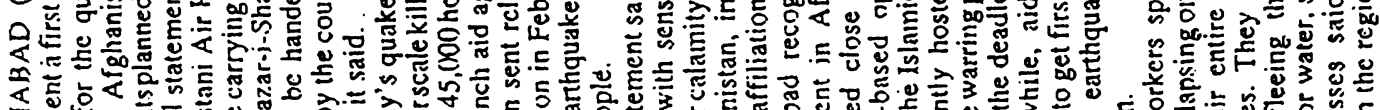

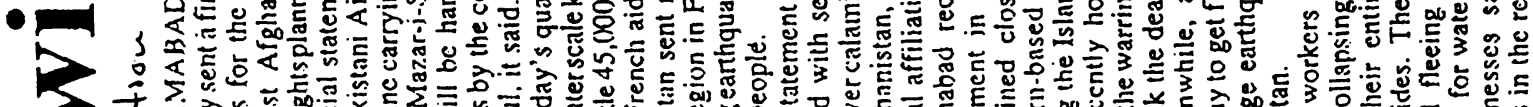

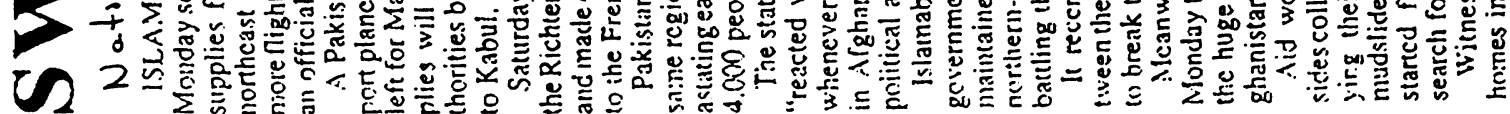




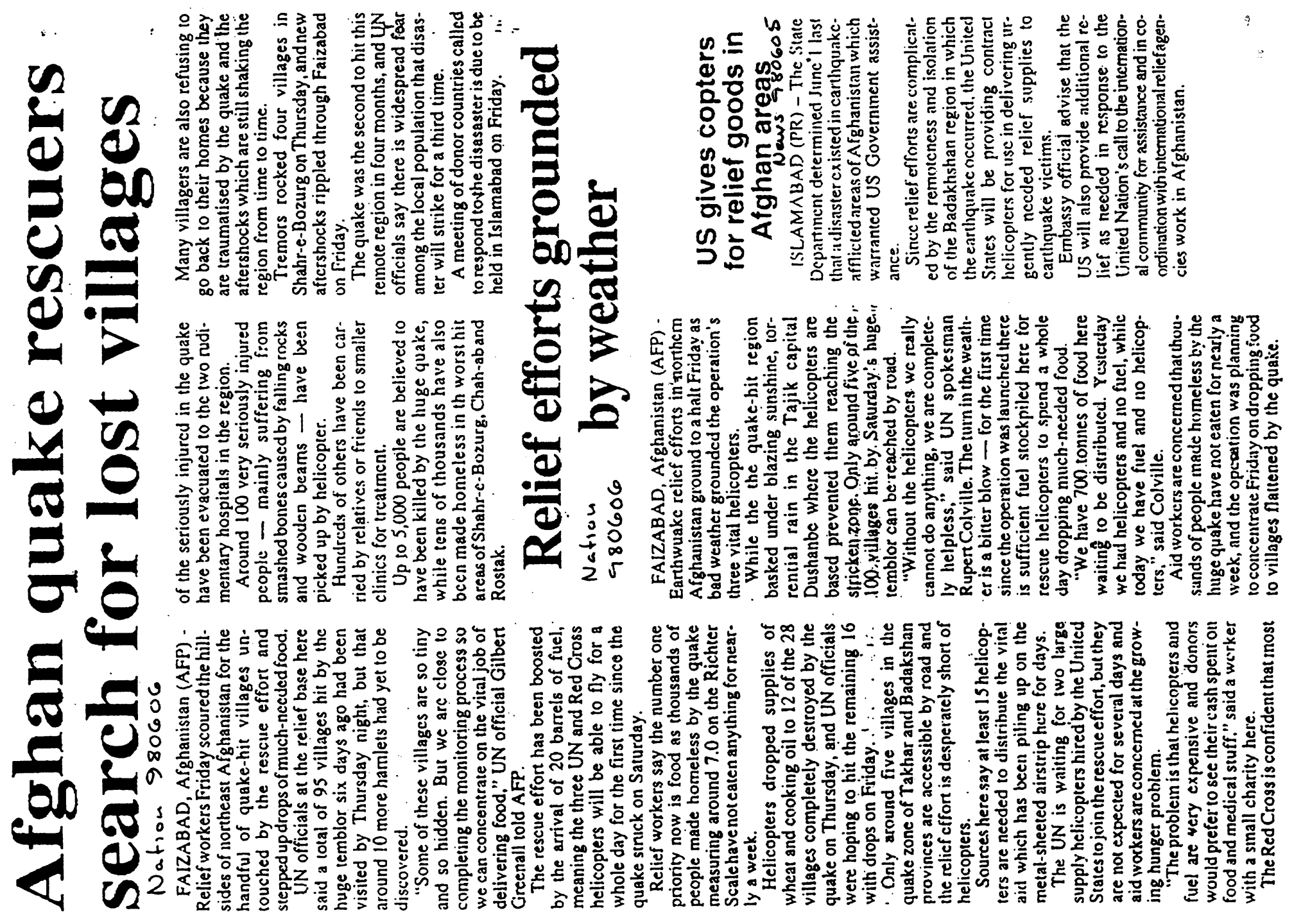

\section{Af 980607 an quake survivors eating grass to stay alive}

FAIZABAD (AFP) - Relict he licopters took to the skies over quake-hit northeast Afghanistan Saturday to drop vital supplies of food. amid reports desperate survivors are eating grass to stay alive.

One week after the massive icmblor devastated scores of villages in the foothills of the Hindu Kush mountain range, the relief effort has been severely ham: pered by bad weather and a shortage of helicopters.

Torrential rain has caused mudsiides that have wreaked further havoc in the shattered rc. gions of Chah-ab, Shahr-eBozurg and Rostak .. where many villagers have been without food or drinking water since the quake strick.

"We lost a whole day 10 bad weather and now there is very reai concern for survivors." UN spokesman Rupcrt Colville told AFP.

"The rain has increased the urgent need to get food and shelter to these villages where conditions must be appalling. We have to also consider the mudslides may have caused more victims," he said.

A dclegation of villagers from the remote district of Shahr-eBozurg arriyed at the relief base camp here with horror stories about a lack of food, water and sheller.

The unly food people have is grass, that is all people arc eating. Children are dying because there is nothing to eat and it is getting worse and worse every day," sajd one man from Chow Ghani village.

The spring and all the drinking water has been covered by landslides. I can't describe it," said the villager, who walked out of Chow Ghani four days ago.

Some 100 villages have teen hit by the quakc, incuding 28 that were completely destroyed, and the death toll is expected to top 5,000 .

However only a handful of vil- lagers can bc reached by road, and the bad weather grounded the three Red Cross and UN heli. copters for 24 vital hours.

The UN has made an urgent appeal for at least 20 more helicopters to allow the aid ettort to function smoothly, but several days later the organisation is sti!l involved in tortuous negotiations with companies in central Asia for their hire.

Hundreds of tonnes of food are piled up here beside the metal. sheeted airstrip, but there is no way to get it to many of the villages pcrched on mountain sides or hidden in deep ravines.

"We are targetting the worst hit villages with supplies of food as best we can with the resources that we have, but it is nor cnough," Red Cross spokesman Juan Martinez said.

There are aiso reports villagers arc starting to desert their shattered homes to search for help. sparking fears of a refugee exodus.

\section{so Israel flying quake aid 2 JERUSALEM (AFP) - Israel wil fly 15 tonnes of aid supplies to earth- quake survivors in Afghanistan on Sunday after several days of uran- gling between governiment ministries over who should pay for the flight. \\ Offlclals said the government would charter a cargo piane to fly tents, blankets and medical supplies to Tallkistan, from where they will be ferried to survivors of the earthquäke Sunday in northeastern Afghanistan which killed up to 5,000 people: \\ 'The chartered plane will land in neighboring Tajikistan and not Afghanistan because that coun- try has no diplomatic relations with Israel,' said Reuben Rivlin, a member of Parllament who will accompany the aid.}




\section{Relief work in quake-hit areas of Afghanistan facing hurdles}

\section{Nation 980609}

By Our Staff Reporter

ISLAMABAD - Chronic lack of helicopters, fuel, bad weather, mudslides and powerful aftershocks are obstructing the rescue and relief operations in the quake-hit areas of northeast Afghanistan.

Juan Martinez, Infortnation Delegale of Intemational Committee of the Red Cross (ICRC) said the rescue efforts were facing hurdles, adding the relief operation could not be smoothly completed with the present size of planes. Martinez is based in Kabul office of ICRC. He was in Islamabad on Monday.

United Nations has asked the world community.to provide some 20 beli-

copters to participate in the rescue and relief operations in Afgharistan: At the moment only three helicopters are cartying away the relief goods from Faizabad, capital of Badakhshan to the villages that were severely hit by the quake nine days ago. It was the second series of tremors in the last four months.

On Saturday: Pakistan announced that it will provide three helicopters to take part away the operations in north. east Afghanistan. However; it has not yet been confirtned wether Pakistan has sent the helropters or not

Martinez ruled out the outbreak of the deadly bacterial disease called. "Shigella" in the quake-hit areas. Foreign news ágencies; in their stơties on Sunday, reported that some people have contacted Shigella in Zarangan

\section{Fro Taliban sign deal to update aviation system}

KABUL (AFP) - Afganistan's civil aviation ministry has signed a dcal with the International Air Transport Association (IATA) improve the communications sys tcrn at the country's war-ravaged airports, officials said Sunday.

Under an eight million-clollar deal. IATA would install saicilile cominunication equioment at the Taliban-held Kabul, Kandahar. Jalalabad and Herat airports. Ariana Afghan Airlines president Mawlawi Mohammad Yunus said. The deal was part of an ambitious Taliban plan to moxicmize and expand the depleted airline, he said without giving the date and place of when the accord was rcached.

The new system will link the domestic airports and establish cuntacts with other airports throughout the region, he said.

It will also provide weather forecasts for Afghanistan, and the neighbouring states which has been a ma jor troblem for Afghan pilots.

To further upgrade Ariana, two Russian-madc aircraft purchased cheaply from a former Sovict re- public - a second-hand Yak-40 and an Antonov-24 costing 360.000 dollars -- would join the theet in a few days. Yunus said.

Ariana also intends buying a Boeing-747 from a Western courity in the ncar future, he said without identifying the countries.

Ariana's deoleced flect includes threc Boeing 727s and one $\mathrm{Ar} \cdot 12$, borruwed from the Taliban airforce.

in March, an Ariana Boeing 727 on a domcstic flight from Kandrit:ar to Kabul slammed into a moun:ain, killing all 45 passengers and crew on board. The crash came just itrec monihs after a Yak-40 on a doncstic flight lost its way and crashed in Pakistani tcritory killing 5 I peojlc.

Last year. the airline lost Russian TU-56 to the anti-Taliban forces when it had flown senior religious officials to the notthern city of Mazar-j-Sharif days oefore the city was captured.

Since September 1996 when the fundamentalist Taliban took Kacul, Ariana has been an all-malc aisiine as part of the religious rulers' poiicy barring women from outside work.

\section{$\underset{\text { Notoon } 980609}{\text { Robbes in Jalalabad }}$}

From Our Correspondent

PESHÂWAR - Once again unrest erupted among the dwellers of Jalalabad, a border town of Nangarhar province, when three houscs were robbed by unknown robbers a few days ago.

During a.visit to Jalalabad, this correspondent came to know that first ever robbery case reported on previous Thursday night near to Sheesham Bagh locality. They dwellers of the locality informed that a group of robbers entered house when its occupants were sleeping and they sprayed some." chemicals.

After making the whole occupants

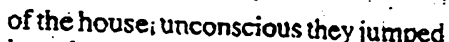
into the next two houses and reperated the same practice: During this period, they not only collected the whole val. uables but even the robbers made food and tea for themselves and later on load the whole robbed goods in a vehicle and escaped.

The affected octuparits of three houses came to know of the tragic incident when they awakcriedearly in the moming. They reported the matter before the Security wing of Taliban's Islamic Tehrik and Talibar yet to. fulfil their responsibilities. It could be considered first ever criminal case in Jalala bad since September 1996 and Saharbuzarg villages near Rostaq. Martinez. however, said that UN reports have confirmed. the fact that some people of the area were suffering from dysentery. He, nevertheless, said that the disease would be controlled.

He also denied the reports that people in the quake-hit areas were starving due to lack of food. "This is a bit exaggeration to say the' people have started eating grass," he remarked. He said though there were some problems in the food supply system but one can't say that they werc starving due to lack of food items.

The Infoimation Dëlegatc of ICRC said that some 3,000 people have died duc to the recent powerful 'shocks. of quake that hit over 100 villages in the provinces of Takhar and Badakhshan.

Israel Mies aid to Ifghian quake victims BEN UURION AIRPORT. [sr.cl (AtY) - An Isracii plane took nff Sunday for Tajikistan carrying 15 tonnes of supplics for earthquake survivors in Afghanistan. The plane will first make a stopover in Georgia to deliver aid to people affected by fighting in that former Sovict republic, officials said. Reuben Rivlin, a member of parliament who is accompanying the night. said the aid mission showed how far Israel has come since the Jewish state was crealed in 1948 in the wake of the Nizi Holocaust in World War II "Just 50 ycars ago who could have imagined that Jews could come to the aid of niher peoples." Rivlin told repor:crs before the Might departed After stopping in Georgia, the Isracli plane will ny to the Tajik capital Dushanbe from where the aid supplies -- ients blankets and medicine wcrth around 150,000 do!lars -- wi!li be carried overland to the Afghan border and handed to UN rescue teams.

\section{Fresh clashes erupt in northern \\ Afghanistan}

ISLAMABAD: After a short lull in fighting, clashes again started among Afghan factions in northern Afghanistan, reports Radio Tehran

Taliban sources claimed that they have taken the control of some positions in the outskirts of Pule Rhumri area, the radio said. Contraty to them, the anti-Taliban sources of United -.. Front claimed that attscks of the Taliban were repulsed and three strategic positions as well as two important areas of Taliban came under the control of United Front forces in northern Afghanistan, the radio ariegr-APP. 


\section{Peace a must for Afghan children's development}

Notrou

By Nafees Takkar 980611

ISLAMABAD - Report on the "Impact of conflict on $\Lambda$ fghan children" says development of children in Af ghanistan cannot be pot on hold until the fighting comes to an end.

The report was released here on Wednesday bringing to surface the positive and negative consequences of war on the Afghan children.

The decades old was has produced disabled and illiterate children that will inherit a war-torn country in the future. The conflict has put restrictions on the educational and emotional development on the young Afghans.

The positive consequences of war, The positive consequences of war, markable resilience among childrein despite the difficulitics they face such as disability, the.death of loved oncs. long absence of from parents, homelessness. poverty, hunger long working hours and considerable domestic responsibilittes.

The findings of the report say chiloren are under direct threat from weapons of war which cannot distinguish between military targets and children or civilians. It says the children have less education becaluse of the conflict. adding giris arc particularly frustrated by their exclusion from education.

The findings further say that chilThe findings further say that chilthe war is the leader's desire for powar and their coercion of recruits to go to and their coercion of recruics money. and ideals are secondary reasons for fighting." It says the ethnic origin is yet another reason which discriminatés the children.

The report on the "Impact of confict on children in Afghanistan" is based on extensive research on 500 Afghan children aged 6-18 acriss five zones of Afghanistan. This research has confimed the findings of Graca Machel's 1196 report.

The report also presents some rec Thmendations to reduce the conflic ommendations to reduce the contlict pred safety and security of prildren in Afghanistan; advocaie the prompt resolution of the armed conflict by peaceful negotiation: suppor for the efforts of Afghan parents and othèr adults caring for children to provide an adequate livelihood for the household and foster the child's, emo tioit and mental dèvelopment

The report focuses on four main themes of the UN Convention on the Rights of the Child; thas is, survival, protection, development and paricipation.

Some of the highlights of the report include, "An escape one day is no guarantee of an escape the day after." Greater, perhaps, than the poverty of hunger is the poverty of being.totaily alone," and "Children have vital stake in the conflict as members of the genetation that will live on to irherit the war-ravaged country."

Summary of the report conducted for include Save the Children Federation, Inc; Save the Children (UK) Pakistán and United Nations Chilidren's Fund (UNICEF).

Apart from others Ellen Van Kalmthont of UNICEF and Andrew R. Wilder also spoke on the occasion. They highlighted the cause of children in the war-tom Afghanistan and urged for an immediate action to resolve the conflict in that country.

\section{Narcotics issue in Afghanistan Taliban slam UN's FP 980611 double standards}

ISLAM $\triangle B A D$ (NNI) - Taliban Islamic Movement on Wedncsday attacked the United Nations for adopting "Joubic stanclard" in cleisling with the rarcolicy issue in Afghanistan.

The UN has shown little pic. parcdness to cuopcratc with the Islamic Emirale of Alyhanistan (s) combat narcolics by providing necessary assistance to the farmers so that they are enabled to replacc poppy cultivatson with other usclus crops," Afghan Embassy said.

"The relevani LiN agencies have. so far, sufficed on spreading thesrics and have acicpied a dual policy or ihe policy of "one rool and two weathcrs" against Afgharustan," at Embassy stastement jaid.

Il lashed out at thic Unitse Nations for inviting the ousted president Rabibani to the Genera Assevibly's special meeting on drug control and said Rabbani duc:s not enjoy any authority in line areas under his control.

Taliban urged the internationsl ceminunily is =xichy sopperation to combat narcolics. instead of labcling baseless accusations ayainst the Islarnic Einiri.te of Afghanistaiz

It reyraflod tiat United Nilions often negotiale narcotics issues with the Is!amic Entirate of
Alghanistan, but the irvitations tor the Gencral Asseinbly sessions on narcolics are exiended in Rabbani and his representatives.

"Such attitude on the part of the intermational community, which is inicresiced in the solutwon of the narcotics problem, will never bing about any yiable solution to iho problem".

Bascd on the insiructions of the sacred religion of Islam and its corninitument to the internationil ubligations and the principles of the international conventions, the Islamic Emiratcs of Alghanistan had declared the struggis against the illicit production, traflicking and use of narcotics. as a legal and Islamic struggle.

As a result of this on Junc 1 . 1998, it publicly bumt $2000 \mathrm{Kgs}$ ol opium in the Ningarghat provinec.

Il said the poppy cultivation in Aighanistan docs not have political motive, but it is the extreme pover(y and critical economic conditions that furce the farmers in grow this crop.

Howeves, hís shall also be nored that the production, processing and risflicking of narcotics are carricd on by profiessional raders and intermitional matia, and nos by the Islamic Emirales of Afghanistan.

\section{Copters drop life-saving supplies in Afghanistan \\ Nation 980609}

FAIZABAD (AFP) - Rescue helicopters Monday dropped life-saving supplies to villagers in quake-hit north Afghanistan who have been stranded without food for nine days, amid fears water supplies may also run dry.

Red Cross officials said the relief. operation's four helicopters hoped to have covered the 50 villages worst affected by the massive temblor with food drops by the end of Monday.

"The main aim is to keep people in the villages. The last thing we want is a lot of people on the move, and they will stay put if they see food, Red Cross official Svante Yngrot told AFP.

The village of Chawgani in the remoie Shahr-e-Bozurg region received its first food since the May 30 quake destroyed more than half its houses. killing around 400 inhabitants.

Desperate villagers, who have been eating grass to stay alive since the quake, swarmed around the helicopter's rotating blades - forcing relief workers to hurl them out of the way for their own safety.

As the two tons of wheat and cooking oil were dragged away from the wind tunnel around the chopper, wornen covered by orange and red burqas accompanied by children sporting multi-coloured hats emerged from the makeshift tents that have now replaced their shattered houses.

The villages and hamlets dotied around the sweeping foothills of the Hindurkush mountain range are so isolated that new quake-hit villages not marked on any map are being discovered every day.

In Chawgani the village's source of water has been buried by a landslide which is forcing the inhabitants to drink from the muddied river or puddles.

There is increasing concem that a lack of clean drinking water will trigger an epidemic of dystentery or even cholera. and water specialists from the British charity Oxfam are leading an urgent initiative to unblock wells and springs.

"It is clear now that many villages are suffering major problems with their water supply. As well as thirst, this has serious health implications,' said UN spokesman Rupert Colville.

'In some places wells and springs are buried under 50 feet ( 15 metres) of eàrth. The rivers have also been tumed chocolate colour by landslides, making the water undrinkable,' he said.

However, an early scare about an outbreak of a bacterial disease called shigella, which is life-threatening if not treated; proved to be a false alarm

Red Cross spokesman Juan Martinez said three people had been examined with severe diahorrea, and that one of them had died.

'We do not know what it is yet, bul the situation has been contained. It is not as serious as we thought, he said

The relief effort is still being ham pered by a desperate shortage of heli copters and aviation fuel. 


\section{Disabled Afghan children being trained to lead honourable life}

\section{From Shamim Shahid Natiou.9806ll}

PESHAWAR - Despite Insing a lot in the 20 years long imposer war, the Afghans have detcrmined to live with honour and prestige. This was observed juring a graduation ceremony of the disabled Afghan cyclists at jalalabad. The ceremony was arranged by the Afghan Amputee Bicyelists For Rehabilitation and Recreation (AABRR). Mr Bashezai. Regional Officer of UNICEF for Afghanistan and Ms Anoja Wijcycsckera. Propect Officer of UNICEF for Eastern provinees in Jalalabad, attended the graduation ceremni) as chicf guests.

Mi Laeq Saeed, an sight ycars oid boy from Kunar movince made the guests and other participants. surrised while recalling his memory that how he had lost his right icg and fingers of left hand in a landmine explosion. His operation was conducted for four times in Lady Reading Hospital,'Pestrawar but could not recover and his poor parents shifted him to AABRR Dffice in Jalalabad. He remained under treatment of AABRR vising Orhopaedic doc iors and Therapists for amund four months and now the innocent victim of impused war, moving fastly in's ards rehabilitation. His right $\mathrm{lcg}$ cren his chest and other parts of the body. still sigrs of explosive hurns.

"I was on my way to school when I was hit by a landinines." remarked Laeq Saeed and later he found hinisclf on an hospital bed. After shifting to AABRR Ofrice in Jalalabad. I got a new vision of life. he said and added that now he wants to become a doctor.. I learnt here the trend of self-reliance and help others. Niow I can run bicycle and can $g 0$ to school on bicvele." He was thankful to AABRR Director Dr Basecrand his teacher Omara Khan. Omara Khan himself is a victim of imposed war and diprived him of his one leg. He urged the UNICEF officers to continue its assistance with AABRR as it is serving those innocent victims of war who have lost their limbs as a result of bomb and andmincs explosions.

Like, Laeq Saced around 14 other chlldren were also facing sinilar problems. Mnst of them had lost their legs and arms but now the AABRR trained them with the belp of UNICEF and other internationa donor agencies to live with honour.

Spcaking on the occasion. Dr Baseer AABRR. Director. said that it is 69th graduation ceremony since the establishment of the institution in 1992. He

said that during this period, they trained around 1,50! people. majosity of wtioin ate children and boys below 18. Besides imparting them bicycle riding training. they are alse educating these innocent victims of the was in various. vocationa skills to ensble them tn become self-sufficient members of thei scxiety; he remarked.

Dr Baseer said that due to lack of census and other dsta, there is mo any exact informations about the maimed people in Afghanistan but it is estimated upto onc million. From fous to seven per cent Afghan population is disabled and such pevple dexerve :o be helped by the International donors. He said that after tretting raining in AABRR institution. these children and even adults get a bicycle alongwith books. The UNICEF has been providing bicycic in these children while Sandigall and other NGOs are providing arificial legs and other relief goods to these children. The UNICEF Regional Director for Afghanistan. Bashezai. whilc expressing his views on the occasion said, "One can easily brild a confidence about the life after listening to 8-year boy and innocent Laen Saced." He said that now he came to the conclusion that Afgharis still want to remain self-reliani and live with honour.

The UNICEF officer further said that todays dispiay shows that $\Lambda$ fghanistar and its people need peace and tranquility in their mothcriand. "I hope that such childrer weruld not only become important members of the society but they could contribute a lot peace restoration in their motherland.

The UNICEF Resident Project Officer in Jalajabad Mt Anoja Wijesekera delighted over her presence amidst those innocent victims of Afghan war who have lost their legs and arns.

She said, "It is the display of courage. vision of a new life and a struggie against disablitity. She was of the firm belicf thal these chitdren on completion of thej training would fccus on edication and would prove themsclves an exasnple for the rest of the Afghan society.

She also suggested the children to encouraze their other mats who were also affected by fighting to remain self-reliant and independent.

Besides facing a threal to their lives of landmines and other explosives. Afohans are also facing polio and informed that in this connection UNICEF is waging a struggie. She said that rou second round of the vaccination compaign is in progres. in all over Afghanistan and she called upon $A$ in all over Afghanistan and to comerate in this ghans from

"What the tragic wat has done? The innocent children are its victims, "Anoja remarked with tears in licr ejes and asked the chtldren now you shouldi to entcourage sthers.

She said that UNICEF is proud of its asscciation with A ABRR like institution whlch is contribuling a Iot in rehabilitations of the war victims. In this connec tion she praiscd both Dr Baseer and Mr Omara Khan who have dedicated their lives for rehabilitation of the war victims, particulariy innocent viclims of the useless war: She was hopeful of returning peace in Afghanistan and assured that UNICEF would continue its assistance with the war affected people.

Latet. keys of bicycles and books werc handed over to all 29 qualified children:

At the end of graduation ceremony, the children displayed various skills of At the eti of griduation cere in. various games like volley-ball, badminton, table tennis and others.

\section{Taliban decide against talks under ulema}

ISLAMABAD (NNI) - Taliban Monday dropped the idea of holding dialogue with the rival Northern Alliance under the proposed "Ulema Commission" calling for new initiative to resume the talks stalled in Islamabad last month.

"As the opposition alliance had disrespected (he Ulema Commission so we have given up $\sigma$ the idea to resume talks with the opponents under this forum," Afghan Ambassador Abdu Hakim Mujahid announced here.

In an exclusive interview with this news agency, he said the OIC or any other country should take fresh initiative for resumption of peace talks.

A few months back Taliban's leadership floated the idea of Ulema Commission to resolve differences within Afghan groups and establishment of permanent cease-fire to help restore peace in the war-torned country.

Asked about United Nations' allegations on Taliban for unilaterally discontinuing talks with the rivals, the envoy clarified, "we hold the United Nations responsible for failure of the Islamabad talks". The UN, he said, overloaded the agenda and unnecessarily included the issues of cease-fire, exchange of prisoners and lifting of blockade.

"We had repeatedly and clearly stated that other issues should be discussed in the Ulema Commission but the idea was rejected by the opponents which led to the collapse of talks." he regretted.

Pakistan has now launched fresh efforts to pave way for the resumption of talks. State Minister for Foreign Affairs Siddique Khan Kanju visited Afghanistan last week and held talks with Taliban and leaders of the Northern Alliance as part of the new initiative.

The United Nations, he said, has adopted double standard in tackling issues. It implemented resolution on Iraq within one month but failed to implement it on Israel and Kashmir.

Asked why Taliban are opposed to the establishment of a broad-based government in the war-shattered country, the Afghan ambassador said, "we are in favour of broad-based govemment sans the warlords. The broadbased government should comprise ethnic groups like Pakhtuns, Hazara, Tajik, Uzbek, Turkmen, Qazalbash and others".

The warlords, who have been playing with the lives of innocent Afghans for years, do not represent the Afghans and have no right to be given place in the set up, he said.

Mujahid said broad-based govemments had been established in Afghanistan under the Peshawar, Jalalabad. Islamabad and Mahipar agreements but that could not work due to lack of sincerity and personal interests of the warlords.

To a question about the strained ties between Taliban and Iran, the Afghan envoy said Taliban had no differences with Iran but "regrettably Teheran has not yet changed its policy towands us".

He alleged Iran was providing political and military support to the Northern Alliance. "There would be room for Iran to play its role in Afghanistan if it changes its policies," he said. 


\section{Opium cultivation in Afghanistan continues unabated}

\section{By Wașim Iqbal News 980616}

ISLAMABAD - An official United Nations Drug Control Programme (UNDCP) in the end of United $\mathrm{Na}$ tions General Assembly Special Session on the world drug problem at New York told journalists that UND: $C P$ dealt with Afghanistan because people were growing opium there and the alternative was to do nothing. He added that 80 per cent of the heroin produced in Afghanistan was shipped through the Balkan or Southern Miediterranean routes to Europe where there were many addicts.

He also said Afghanistan had made a clear agreement with (UNDCP) and was providing evidence that its promises were not empty words. Arlacei. executive director, UNDCP went 10 Afghanistan after the $1997 / 98$ planting session. He stipulated that UND$C P$ projects would only be implementcd if Afghanistan prohibited the use. production, and refining of opium poppies.

The Taliban government honoured the deal by issuing a proclamation prohibited the production and refining of opium, except for what had already been planted. This was also evident from the fact that they recently burnt $2 \mathrm{MT}$ of opium confiscated from the newily-cultivated areas such as Kama, Alingar, Alishang, Qargahi and the vicinity of Laghman.

The United Nations Drug Control Programme's recently completed its fourch annual opium production sur-

vey in Afghanistan which had undeitaken in 18 provinces. Eight more provinces were surveyed in. 1997 than in 1996 including Baghlan, Herat. Jawzjan. Kunduz, Paktia, Pakika, Sari Pul and Takhar provinces. Reports of poppy cukivation in Baghlan, Herat and Jawzjan were verified and measured by the survey team, whilst in the other five new.provinces covered by the sirvey in 1997, significant amounts of cannabis were discovered but the cultivation of poppy wa un confirmed.

In 1997, riew areas of opium poppy cultivation included Dahaneh-eGhowri district in Baghlan province. PashtunZarghun district in Herat province and Balkh and Char Bolak districts in Balkh province. Hilmand re tained its dominant position as the largest cultivator and producer of opium. The provinces of Hilmand and Nangartiar cultivated approximately 75 per cent of the total poppy cultivatod in Afghanistan in 1997.

Although the agricultural conditions in most of Afghanistan are conducive to opium poppy cultivation, yet it is not grown country-wide. Indeed. a majority of provinces in Afghanistan do not grow poppy and in those provinces where opium is grown. 60 districts were found to cultivate poppywhilst the remaining 67 districts were poppy free. Even. in those districts where opium is cultivated intensively there are villages where poppy is not currently grown, and at the villagelevel, a significant proportion of house'holds might not grow poppy cven in areas where the majority of households cultivate opium intensively.

Rumours of an impending ban on poppy cultivation by the Taliban may have had some influence on farmers decision to increase poppy cultivation in these areas this season. The shappest decline in opium poppy cultivation in 1996 to 1997 was reported in Oruzgan and Nangarhar where cultivation fell by 41 per cent and 7 per cent.

Afghanistan is one of the world's poorest nations. Over 80 per cent of the population is dependent on agriculture as a source of livelihood. The farming sector is also structurally weak, with poor matketing. small landholdings. an absence of formal credit facilities and a shortage of irrigation. Environmental degradation, low quality inputs and poor agronomic practices have led to extremely low production, resulting in food deficits of between 2 to 7 months. Moreover. 18 years of war has led to extensive damage to the nation's physical and administrative infrastructure with a concomitant loss in social. legal and economic services.

An estimated 200,000 farmers in Afghanistan cultivated approximately 58,000 hectares of opium poppy in 1997, producing an estimated 2.800 metric tonnes of dry opium. The total value of this production at farmgate prices at harvest time was an estimated US\$ 94.6 million, representing USS 473 per farmer. However. poorer households have been found to sell their entire opium crop 2.3 months of approximately 25 per cent from the prior to harvesting at $20-30$ per cent 1996 total of 2,248 metric tones. The less than trarvest price. The real gains are realised post harvest when prices may increase by as much as 100 per cent within two months.

The survey reports that a total area of 58.416 bectares (ha) under opium poppy cultivation in Afghanistan during the 1996/97 growing season. In total 13 provinces of the 32 provinces in Afghanistan were found to cultivate opium poppy. Hilmand $(29.400 \mathrm{ha})$ and Nangarhar (14.567 ha) together accounted for 75 per cent of the area under opium poppy cultivation. To a lesser extent, opium poppy cultivation was reported in Oruzgan (4.587 ha) Qandahar (4.521 ha). Badakhshan (2.902 ha), Nimroz (642 ha). Farah (568 ha), and Zabul (154 ha). In the provinces of Kunar and Jawzjan. respectively, less than 1 ha of opium poppy cultivation was found.

New areas where poppy was cultivated in 1997 included Heart (38 ha) Baghlan (328 ha) and two new districts in Balkh (178 ha). Reports also revesls that opium poppy cultivation was being undertaken in the provinces of Jawzjan, Sari Pul, Kunduz. Takhar. Paktika and Paktia. Whilst in Mordyan district of Jawzjan province. two small poppy fields totalling less than 1 ha were found, in the other five provinces significant amounts of cannabis were found but no evidence of poppy cuitivation.

Compared to the results of the 1996 survey, opium poppy cultivation in Afghanistan showed no significan change remaining at approximately 58,400 hectares, which is a margina (2.8\%) increase of the area escimated for 1996. Increases of 43 per cent and 18 per cent were reported in Qandaha and Hilmand respectively, the highes provincial increase of 1996 to 1997. While the area decreased in Oruzgan and Nangarbar by 41 per ceni and 6.9 per cent respectively.

The provinces currently under the control of the Taliban provide 96.4 per cent of Afghanistan's total opium production. In 1997 an estimated 2,800 metric tones of opium was produced in Afghanistan. This figure would suggest an increase in opium production main reason for this increase is the increase in yield in most provinces, but specifically in Hilmand province. This yield increase in Hilmand (34.3 \%) combined with the largest area under cultivation in this province $(29,400$ ha increased by $18 \%$ from 1996) is the most important single factor contributing to this year's production increase. Whilc the opium production decreased in Oruzgan and Nangarhar by 76.9 metric tones $(20.8$ per cent) and 45.7 metric tones (6.7 per cent) respectively.

Opium yields from $22.8 \mathrm{~kg} / \mathrm{ha}$ in Badakhshan to $64.0 \mathrm{~kg} / \mathrm{ha}$ in Oruzgan. The average national opium yield in 1997 was $48 \mathrm{~kg} / \mathrm{ha}$. The estimated vicld has at the provincial level in-

creased throughout the opium growing provinces cxcepl for Nangartiar where it has remained the same, and Nimroz and Zabul provinces, where it bas decreased.

The increase in yields ranges from 12.3 per cent in Badakhshan to 46.8 per cent in Balkh. The national level increase in production is caused most significantly by Hilmand province with an area increase of 18 per cent to 29.400 ha combined with an increase in yield of 34.3 per cent.

It is certainly clear that the motivations and factors that influence household opium cultivation differ actoss socio-economic and spatial groups, paricularly in Afghanistan where the prevalence of landlessness has led to a livelihood strategies of landiord and sharecropper.

It is important to recognise that the number of the provinces found to be cultivating opium poppy has increased since the inception of the surveys in 1994.

Moreover, it is apparent that an increasing number of farmers have the expertise to increase their opium yields. using irrigation and fertilizer to increase the production of higher yielding varieties of opium poppy: Consequently, an increase in the number of provinces growing poppy and in the amount of opium produced remains a constant threat in the current economic and political environment in Afghanistan. symbiotic relationship between the

\section{Exports of $A$}

KARACHI (NNI) : The exports of Afghari-design handmade carpets from Rs 3 billion in the 11 monttis of 1997.98 .

In 1996-97 the expoits of Afghan-style carpets, known as. "Peshawar Collection" was in the range of 2.25 billion rupees which posts an increase of 750 million during this finincial year because of increasing demand of this variety all over thee world, says a research report of Wool \& Carpet Review magazine

Seeing increasing demand of Afghansiyle carpets almost all the major manufac turers-tumed-exporters have started manufacturing these carpets in Pakistan.

Previously they wcre totally dependen on the Afghanis manufacturers as far as the export of "Peshalvar Collection" was concerned.

Now Afghan carpets exports comprise

\section{fghan carpet}

30 per cent of the total exports of carpets from. Pakistan of which 20 per cent are being knitted in Pakistan by the major mantfacturers. The world wide Pakistani-made Afghan carpets include $\because$ Peshawari Karghahi, Kazakh, Harez; Serapi, Hitchlu. Turkoman, Sehra, Beshiri, Feclpa, Khal, Mohammadi. Bluchi and Kfkazi.

These carpets are being demanded by American and European importers in large quantitics because of their charming and new-look modified designs which reflect the historical scenes, tribal looks and appear a totally new product.

Afghan carpets had not been unknown to Western consumers. The reason whey there is such an increased demand for Afghan carpets is that these are not traditional Afghan goods. They are new products developed by the mutual combination of wiestern imporers and Pakistani manufacturers 


\section{Taliban also stop}

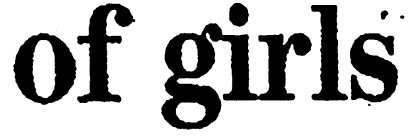

private KABLL: The Taliban religious army on Tuesday shut down more than quiety educating thousands of girls, in defiance of the Talibar's ban on education for girls.

The Taliban's Religious Affairs Minister Haji Khulimuddin announced the closures at a news conference in the beleaguered capital and warned that anyone who defied the ban would be punished.

Until Tuesday the Taliban had al. lowed the schools to operate, but without officially recognising them. Il was not immediately clear what caused the clamp down.

A survey conducted in January by several international aid groups showed that at least 107 so-called informal schools were operating in Kabul, providing education to more than 6,500 children, half of whom were girls.

When the Taliban religious army swept into Kabul in September, 1996, thes shut down girls schools saying the curriculum was against the tenets of Islam. Schools for boys have since re-opened and the Taliban have allowed girls, eight years old and under, to study, but on!y the Quran. After eight years old the girls have to leave school.

Khulimuddin told reporters that the Taliban had discovered several 14 -and -15 -year -old girls receiving education in private homes. "These schools weren't just for children. They also included 14 and 15 year old girls," he said. "These schools were operating against the principles of Islamic law.": The Taliban announced to shut down vocational training programmes for girls as well. This effectively shuts down dozens of programmes, like carpet weaving and sewing projects, that had been quietly running to give young girls a skill and earn money.
This rule will seriously affect all community-based programmes for girls and women," said one interna tional aid worker, who asked not to be identified.

The Taliban's religious affairs minister also accused foreign aid workers associated with these home schools with propagating anti-Taliban propaganda.

The Taliban's Islamic law bans women from working and girls from attending schools. But it also bans music, most forms of light entertainment. It requires men to grow beards, wear a head covering and attend the mosque.

Khulimuddin said that school operators will have to apply for a license from the ministry of education before they will be allowed to operate. "Right now we have no control over these schools," he said adding that "if they get permission then we can control them."-AP

KABUL: In their first double amputation Taliban surgeons publicly chopped off the right hand and left foot of a man convicted of highway robbery, witnesses said Saturday.

Four surgeons wearing medical uniforms and blue masks carried out the 20-ininite operation Friday at a thinly atterided local football stadium here after anaesthetising the convict Bashir Ahmad, witnesses said.

Bashir, said to be from Kapisa province northeast of Kabul, was convicted of snatching 17 million Afghanis (500 dollars) from three travellers at gunpoint recently

ATliban soldier showed the sen ered limbs to the people watching the amputation, while a military he: licopter hovered over the stadium where Taliban soldiers outnumbered spectators.

In the past five months at least five convicted thieves have had their right hands cut off in public in the Afghan capital. - AFP
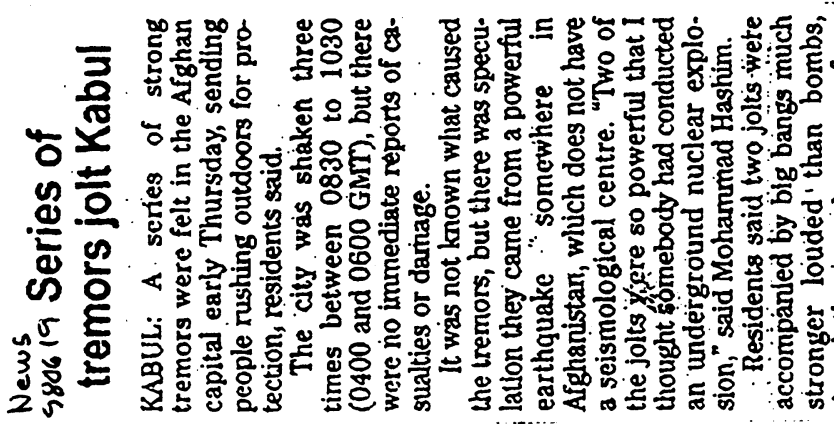

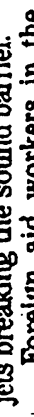

政

\section{Taliban curbs on community}

\section{programmes slammed}

News 980

KABLL: Western aid workers SaturAfghanistan's Taliban rulers of dozens of private schools and vocational centres for women in Kabul

They said the curbs put hurdles in the way of the humanitarian work of international non-governmental organisations (NGOs).

"It is a matter of deep concem," said Warren Buttery, head of the Agency Coordinating Body for Afghan Rellef (ACBAR).

He told reporters the restrictions affected community-based activities including health projects.

"It is extremely demoralizing. We are trying to work here in Kabul to provide aid, but we have massive hurdles put in our way," he said.

The policy followed by various
Taliban organs is very "inconsistent", the ACBAR official comptained, noting that permission obtained in the past from different ministries for women's work was cancelled.

The Talibari last.week said they. shut down unofficial schools for girls and vocational centers for women becalise they contravened Islamic Sharla law and were used for propaganda against the Islamic militia.

The NGOs have decided to "cohesively".. deal with this problem which, if not solved, would have long-term affects on health care here, Warren Buttery said.

Around half of Kabul's one million residents depend on aid provided by the western NGOs, the United Nations and the International Committee of the Red Cross.-AFP.

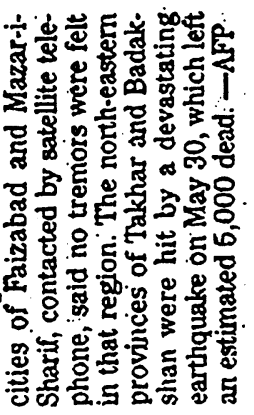

\section{UN resents closure of girls schools in Kabul \\ News 980618 \\ The Taliban made laws ban girls} By Amwar lqbal

ISLAMABAD: The United Nations Wednesday sought an emergency meeting with Afgharistan's Taliban militia over its decision to close Kabul's home-based schools for girls.

On Tuesday the Taliban officials in Kabul shut down more than 100 private schools, many of them educating girls. The closures will have a devastating impact on the welfare of many of the city's neediest people - particularty women and children," said a statement issued by the office of the UN Coordinator for Afghanistan in is lamabad.

The Taliban also closed scores of vocational training programmes, run by international aid groups, for girls and young women.

The Taliban's decision "violates the letter and spirit of the memorandum of understanding signed by senior Tajiban and UN officials on May 13, " says the statement.

On Tuesday the Taliban-tun Kabul radio said they closed these institutions becaise they were running outside the Afghan law and against the religious' beliefs of the Afghan Muslims. above eight from attending schools and even these young girls can only receive religious instructions. The Kabul radio said the banned schools were imparting education to older girls. These were all private schools run by women teachers laid off their jobs by the Taliban after the militia seized Kabul in 1996.

For nearly one year the Taliban allowed the schools to operate without officially recognising them.

UN officials say that there were at least 107 home schools in Kabul, teaching 6,500 students, mainly girls.

The UN reminded the Taliban that while signing the May 13 agreement, the militia promised to discuss proposals for providing education and health care for women and girls with the world body.

The agreement also proposed es. tablishing a joint committee to discuss these problems. The UN coordinator for Afghanistan and the Taliban minister of planning were to co-chair this committee.

But so far the committee has never met "despite requests from the UN to arrange a date, time and agenda," the statement said. 


\section{The shambles of Pakistan's Fp 980621 Afghan policy}

\section{Ahmad Rashid on the Taliban in Fundamentalism Reborn? - a book edited by William Plaley}

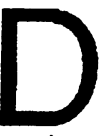
uring 1995 the isI continued to debate the issue of greater sup port for the Taliban. The debate centered around those largely covert operations on the ground, who wanted greaier support for the Taliban, and othe officers who were involved in longer term intelligence gathering and strategic plan ning. who wishod to keeo Pakistan's sup port to the minimum so as not to worsen tensions with central Asia and Iran.

The Pustitun grid in the amy high command eventually played a major roie in determining the military and ISI's decision to give greater support to the Taliban. Both the army chief General Abdul Waheed and the head of military inteiligence lieutenant General Ali Kuif Khan were Pushtuns as were all operational ISI field officers involved withe Taliban. The military appear to have decided by the summer of 1995 that the Taliban were the only possible alternative for Pakistan's own strategic interests in Afghanistan, especially as President Rabbani appeared to be getting too close to Pakistan's rivals-Russia, Iran and india. Another major factor was the ISI's reiuctance to nust Rabbanis commander Ahmad shan Massoud. who had a running battle with isi since the 1980s.

When the Taliban launched their second attack on Herat. the ISI weighed in with a limited, amount of military support. This inciuded croviding ammunition for large calibre machine-cuns and artillery shells, of which ite Taliban were short: extending their miitary wireless network: and helping the fledgllng Taliban air force, which doubled in size after the capture of Herat. But the ISI's ability to provide sustained military support was severely hampered by serious finencial and logistical restraints and a continuing debate within the ISI and betweer: the army and the ISI as to be benefits of long-term support to the Taliban.

the ISI also helped the Taliban by providing them with hundreds of ex-Atghan army cfficers and technicians who had sought shelter in Pakistan atter 1892. Many of these officers were linked to general Shahnawaz Tania, the former second in command of President Najibullah's armed forces. who led an abortive coup attempt againsi him in March 1990. Tania's coup was backed by Gulbuddin Hekmatyar and the IS! but its failure forced Tania and his men to flee to Pakistan where they were given refuge. Tanai belonged to the Khalq faction of the people's Democratic party of Afghanistan. Khalq was predominantly pust:tun and many of its officers were ardent Pushtun nationalist. These officers saw the Taliban as a possible vehicle for a Pushtun resurgence in Afghanistan and thus were willing to join up with the studerits, oven though they had little else in common with them. By the time the Taliban captured Kabul, their entire air force and a captured Kabul, their entire air force and a
large section of their armour and heavy artillen were being manned by former Khalqis. By then Hekmatyar had fallen out with Tanai and in a bitter rebuttal of his for. mer ally. Hekmatyar claimed that over 1,600 Khalqis were now working for the Taliban.
The foreign offlice is out

In Islamabad the involvement of severa ministries, corporations, provincial governmenis and the ISI effectivoly sideiined the Pakistan foreign ministry, which has less and iess 10 do with policy formulation towa:ds the Taliban. The competition within the government only further fragmented Pakisian's decision -making on Afgr anistan. The foreign ministry's in effectiveness reduced Pakistan:s ability to courter the hostile criticism from neighbouring ccuntries of islamabad's supcort for the Talitan. After the capture of Heat by the Talitan. Iran Russia and the cerier Asian republics became openly hostile to Pakistan. And after Kabul fell to the Taliban in 1996 all the regional states again made it clear to Pakistan now they opposed the Taliban's expansionist aims.

The ISI played a leading role in helping the Taliban's capture of Jalalabad and Kabul, by first helping subvert the jalalabad Shura and offering its member sanctuary in Pakisian and them allowing the Taliban to reiniorce their assault on Kabul by fresh troops drawn from Afghan. retugee camps on the border. Pakistani diplomats and ISI officials arrived in Kabul promising all -out support to the Taliban and the jamiat-iUlema-i-Islam (JUI) sent a delegation to help the Taliban write a new Afghan constituticn.

The Indian bogey

The iSl had became deeply concerned tha: an unholy alliance had sirung up between the regional states that would soon include India. But efforts to defuse the tension. such as the secret visit to Moscow in November by ISI Chief Lieutenant-General Naseem Rana and the prime minister's sper. cial Envoy ljlal Zaidi's visits to Iran and cen tral Asia, did little to defuse regional tensions. The more Pakistan demonstrated its suppor to the Taliban, the greater the anger and frustration amongst the regioral states.

BY May 1997. when the Talibar launched their abortive bid to take over Mazar-e. Sharit, the military and the ISI had calculated that a recognised Taliban government which controlled the entire counin; would be easier to deal with than a Tainan movement. Moreover the ISI estimated that all the regional states would then have to deal with the Taliban reality and these states would look to Islamabad to demonstrate leverage over the Taliban and imrove their own relation ship with them. it was a gamble that seriously misfired when the Taliban were pushed back from Mazar-e-Shanif after were pushed back from Mazar-e-Shat uffering thousands of causalities.

For many experts in and out of government. especially for Pakistan's frustrated diplomatic corps it was another classic example of Pakistan's overreaching foreign policy aims and ambitions, which were set in the Zia ora when the country cloud at least claim lavish support form the USA< China and Saudi Arabia. But in post Cold war era Pakistan had noither the resources, nor the domestic economic and political stability io sustain such an ambitious foreion policy. Yet the fact remains that with the constant in fighting and over lap on Atghan poicy within the Pakistani establishment and the lack of any serious attempt to create a high-level decision-making body that could make and implement policy. Pakistan's strategy towards the Taliban was characterised as much by drift as by determination. Islamabad's policy was as much driven by corruption, infighting and inefficiency as it was a concerted attempt to push forward a Pushtun agenda in Afghanistan

Taliban tail wags Islamabad dog

And the Taliban had become masters at using these differences within the Pakistani establishment to their advantage, extracting the maximum benefits from Pakistan without giving any political concession in return. thus instead of using its clout with the Taliban to exert leverage on them on key political and social issues. Pakisian appeared to fritter away its authority and respect amongst many Afghans a respect that had been built up over two decades of support for the Afghan Mujahideen and the Afghan nation.

The Taliban movement has extremely serious political implications for Pakistan. which the military and the political efite the country first ignored and by began to grasp after the battle fro Mazar-e-Sharif. The after the battle fro Mazar-e-Sharif. The
Taliban's close links with Pakistani society, their uncompromising stance on their version of Islamic values and the fact they the sion of Islamic values and the fact they the represent a new form of islamic radicalism of Pakisiani madrassa students. Give them far more clout inside Pakistan than other Afghan Mujahideen groups. For many Pakistanis the Taliban are an inspiration.

Moreover, after the balte for'Mazar, the Taliban had virtually won over all those more traditional islamic parties in Pakistan such as the Jamaat-e-Islami, who had at first viewed them with suspicion. As. Nawaz Sharif's government slipoed into inenia six months after being voted into power in February 1997, most major Islamic parties publicly declared that they had lost taith in partiamentary politios and aimed to mobilise a mass movement for an Islamic revolution by the end of the year. Any such movement will almost certainly be ioined by the thou sands of Pakistani madrassa students who have fought alongside the Taliban in Afghanistan. Armed, trained and motivated. these students would be a formidable force for any state apparatus to encounter.

With Pakistan's civil state machinery eaten away by corruption and ineffective ness and growing pubiic disillusionment with the political system. the law and order agencies would be unable to cope with an Islamic movement which wold be violem and self sacrificing. Almost immediately. such a movement would come up against the army. But the middle and lower echelons of the army's officer corps are themselves now full of fervent fundamentalist officers. many of them having graduated from a madrassa siyle education rathe than the public schools of the ruling olite. In any future prolonged confrontation with Koran-waving Istamic youths, the army's more secular high cormand would be hard pressed to order their troops to open fire. The threat of an Islamic revolution in Pakistan had never been greater.
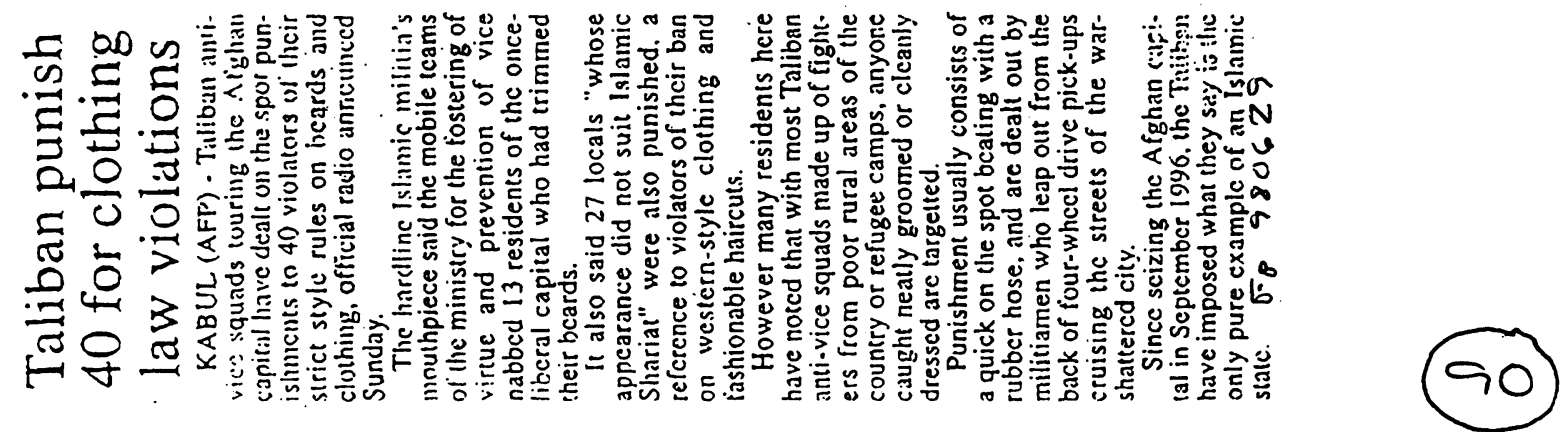
10 The Frontier l'ost' Sunday. June 21. 1998

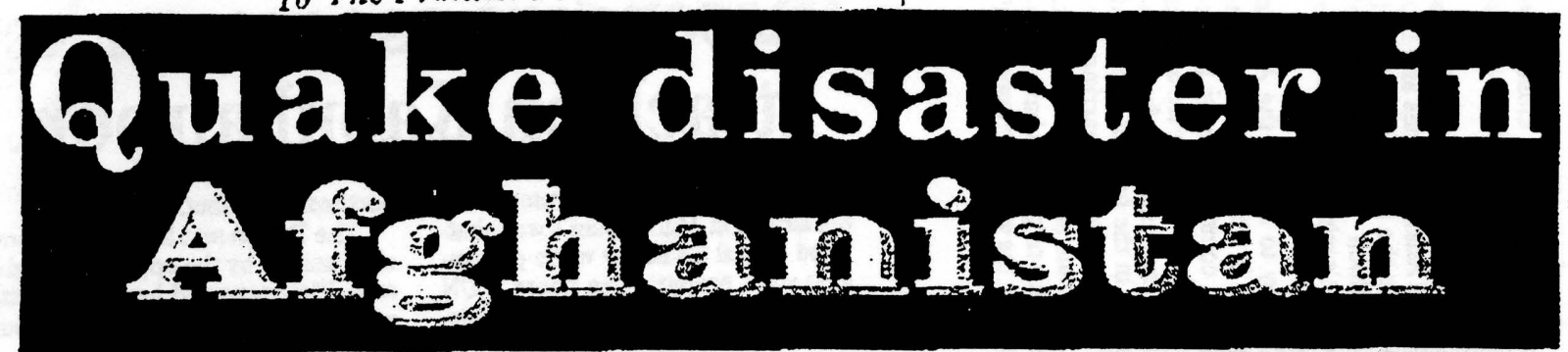

\section{By Carla Power}

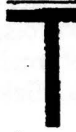

aid workers knew . a rithquake had killed is many as 5.000 people and wreaked havoc on 95 villages in orinern Afghanistan. Thousanes of survivors needed help-arid the international rescuers ceulcn"t do a damn thing about it They nad plenty of good will on -and last week nations from the Netterlands to Iran donated morey and provisions. They had lleets of experienced workers with satellite phone. stretchers and medical supplies. They h.a.s $1000-700$ tons of were sitirg on the old Russianbuilt a!rstro in Badakhashan. But they didn thave decent woather. Rain anc hal poured down on the airstip. keeping planes. and helicocters from making it to the disaster area and back. "It's basicals $\geq$ probiem of logistics. not of money: said

Eventivally, the rains eased: ast Szivrday the United Nations lew tnrse planeloads of food and ients to the earthquake zone. Oomer supplies made their way in by helicopter and donkey carava- Thai was at least some comfor io those who live in the devasiated region of Shahr-edevasialed region of Shahr-eBozoro. which olters a gorgeous vista of green hills and fiere mountains. Shepherds and farm-
ers bur: their mud homes into the hiltsides, saving the precious valley soll for their flocks, wheat fields and purpie and white opium roppies. When the massive quixe struck at 10.52 a m measusing 7.1 on the Richte? scale, sntire communities tumbled dewn like so many rocks in a lancslide. Most victims were wome: and children, crushed while men worked in the fields.

Duing breaks in the wealther. rescie thoppers had to touch down where they could One Red Crcss team landed atop a mourtan. then hiked 15 kilome tres $\propto$ ivn to the remains of a vit lage. idagencies found villages last ireek that had never apoez:ed on any Western map. Some of them are reachable only zy dint paths wide enough for a sinkey or horse - not a irusk with wheat. tarps and modicine. Shere was a lot of work to do, and. at least in the immodiate sermath little with which to do it Fuel is precious in the regicn, fetching $\$ 10$ a litre in the ' amiz: from Pakistan, helicopte ope:a:cons were severely limit-
Bd. "We have asked all the world's countries to intensify their co-operation and support." said the locai governor. Syed Mohammad Amin Tariq

The quake offered a bleak diversion to Afghanistan's unending civil war. Tloops of the northern warlord Burhanuddin Rabbani, which control the quake zcre. loitered around the airstrip and roared around town in jeeps. Rabbani's enemies in the Taliban, the fierce islamists who control Kabul and most of the rest of the country, stayed on the sidelines "we do not intend to send relief goods," the Taliban information minister. Mulla Ami Khan Muttaqi, announced. "we should first defend." Rabbani's forces said they were confident the Taliban would at least not interfere. "There are no Talibs nere," Tariq told a female Western journalist. "If there were. you couldr:t talk to me.

The latest killer quake was Afghanistan's second of the year. The first, which hit the town of Rustaq during winter snowstorms in February, measured 6.3 on the Richter scale and killed nearly 4,000 . The tall, turbaned men who guarded the wheat vegetable oit and plastic sheeting at the northem airstrip last week were still speaking in hustied tons of the February

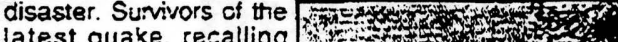

Fetruary's iiller aftershocks, refused to go near any structures that were still standing. Lașt week most were living in tents of carfits and biankets; many pecple hadn't eaten for deys and were too frightened to search in the rubble for food. When an aftersincck raised a cloud of dust at one village, peopie fell to their knees in praver.

Many of thie wounded ended up in the Faizabad Hospital. a dusty 60-bed facitity. Sc:eaming children were ushed to the operating room, and griz zled men sa: glassy-eyed ai the bedsides of their women relatives Abdul Khaliq tencierty readjusted Whalla tencarty readjusted hail over the head of his niece. Firoza. He pointed out the scart ho had lised io bandage her head wound. Firoza, who had never been to a doctor bofore. was sem:conscious, moaning softly. In the operating room, surgeon wo es and ciacked ibias and femurs, tsing plaster of paris and solints. Some women patients covered their faces with

head scarves; others stared blankly at visitors. Of course. even those without physical iniuries were deeply wounded. "I want to go back to my family and see my relatives and my son," said 35-ysar-old Miradjuddin. Her other son, 8-yeat-old Najad. was killed under a collapsing wall. Count it as one more small loss in a nation that can produce tragedy on any imaginable scale.

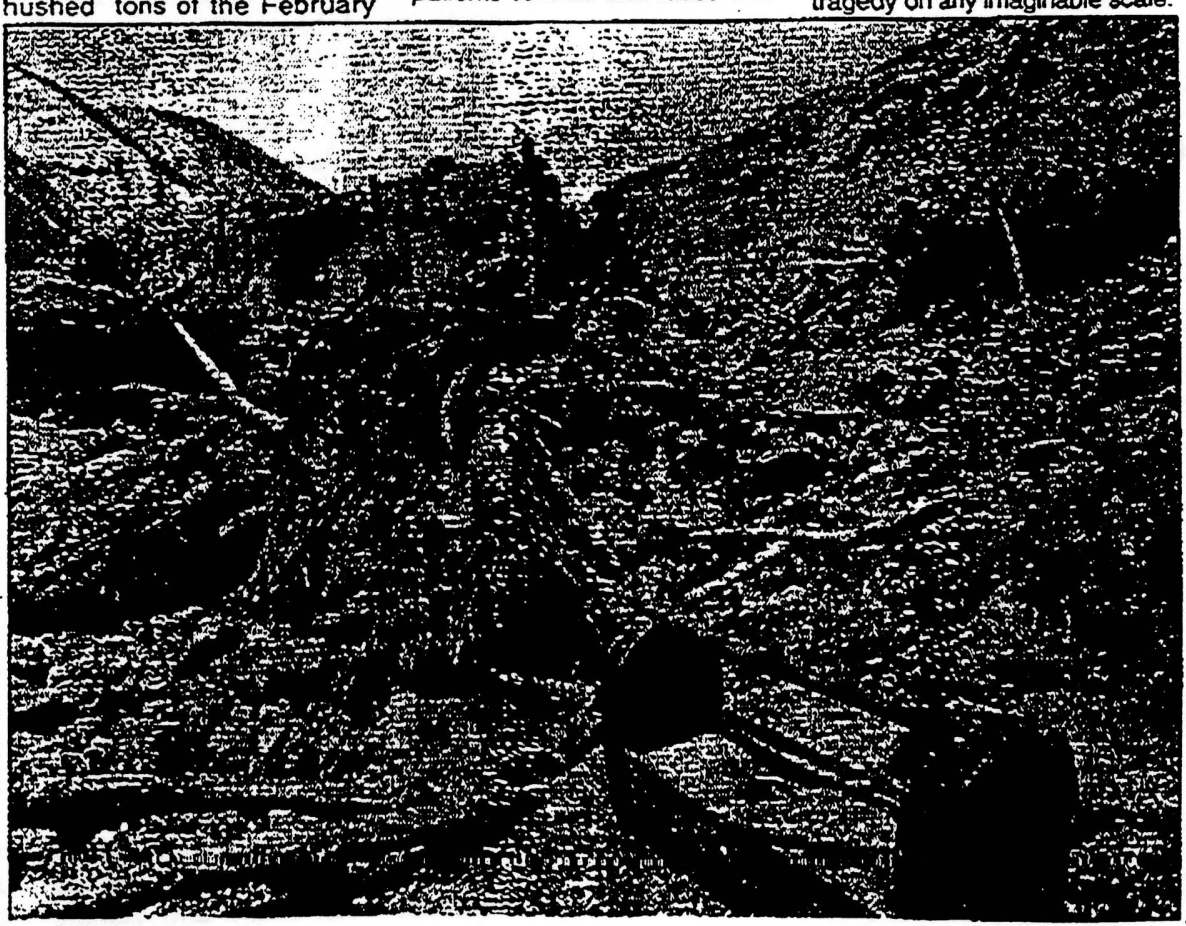

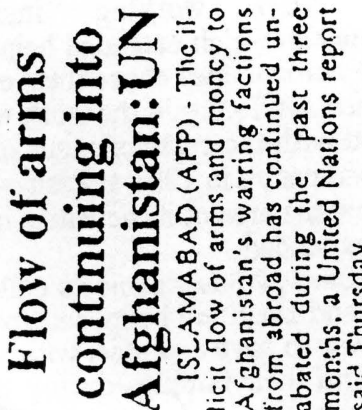

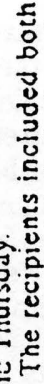
200

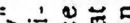

\begin{abstract}
$\dot{0}$
\end{abstract}

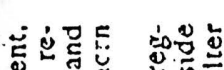

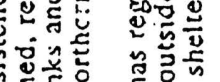

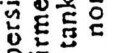

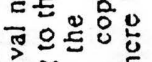

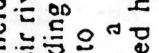

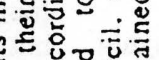

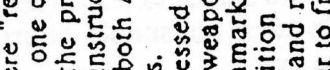

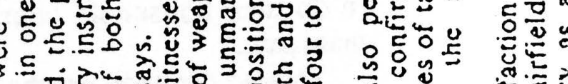

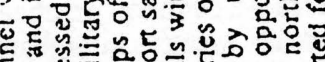

$x$ v

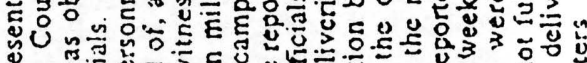

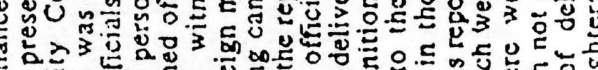

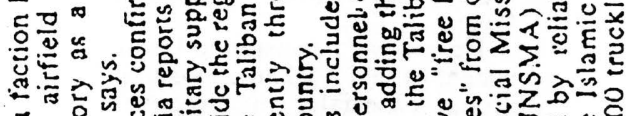

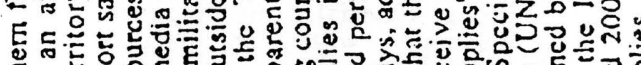

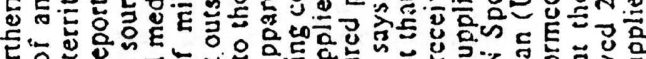

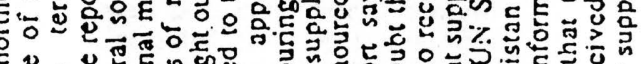

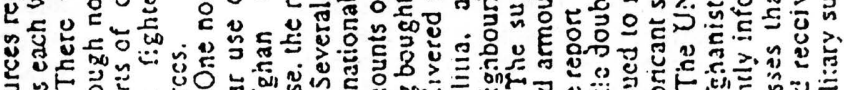




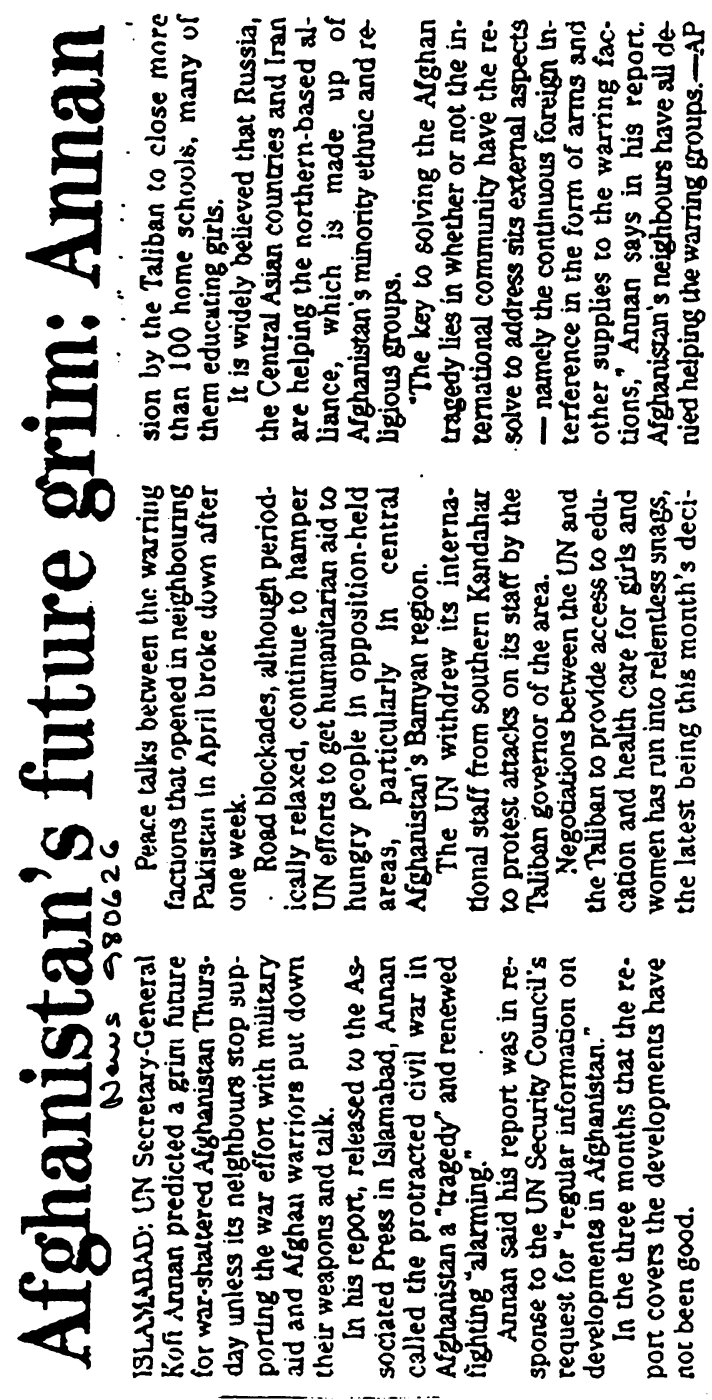

\section{POSt Fricay, June 26, 1998 \\ Fl Afghan rivals mull anti-Taliban \\ strategy \\ ISLAMABAD (NNI) -} Leaders of Afghanistan's major opposition groups are engaged in extensive consultations to chalk out joint strategy against the Taliban militia. Atghan sources said here on Thursday.

Former Afghan Defence

Minister Ahmed Shah Masood and Chicf of Hizb-i-Islami Gulbaddin Hekmatyar have held a series of mectings in the northem city of Mazar-i-Sharif and discussed matters rclating to launch joint offensive against Taliban in different provinces.

Chief of Itchad-i-Islami Abdur Rab Rasool Sayyaf, who has kept himself away from the TalibanNorthern Alliance's conflict for several years. has now ioined hands with the anti-Taliban forces. Afighan sources say Hekmatyar. Massod, Sayyat and General Dostam have agrced in suppore each others forces in difterent areas against the Taliban forces.

Hekmaryar's decision to throw weight behind Aighan opposition group. especially his frequent meetiags with commander Masood, is being viewed as a sig. nificant change in Aighanistan's situation. It is believed that the opposition forces mighe launch offensive against Taliban forces in : Badghees. Kunar, Laghman. Sarobi and north of Kabul.

\section{Passengers escape rocket attack on Kabul airport}

\begin{abstract}
KABLZ: Three rockets slammed into the airport in Afghanistan's war-shatrered capical Thursday while passengers were preparing to board a UN plane parked on the tarmac, witnesses said.
\end{abstract}

There were no reports of injuries in the first arack on the aiport in two weeks.

One rocket landed 100 yards (metres) from the civilian termiral, where people were gathered for the UN fight :o neighbouring Pakisian, UN officials said on condicion of anorymity.

The other two rcckets landed on the western edge of the aipor coinpound where milizary aircraft sre located, they said. People on the roud leading to the aimport scurried for cover. Shops quickly closed and dozens of people sought sheiter.

The rockets reportedly care from corth of the capital, where opposition soldiers are fighting Taliban troops. The attack followed heavy fighting in the Tagab area Wednesday, 35 miles northeast of Kabul.

The Takban said it repulsed a pow. erfil assauit by the opposition in that area. They reported heavy casualties on the opposition side, but that could not be confirmed.

The Taliban, which has imposed a strict form of Isiandc rule in the 85 per cent of Afghanisean it controls, is batting an alliance of several smaller groups on three separate battlefields, all north of the cita

Opposition leaders contacted by sateilite telephone aiso reported heavy fighting in northern Kunduz province on the barder with Tapijistan and controlled by the Taliban.

Shorty before dawn on Thursday, the opposition launched a two pronged attack at Bangi and Aala-a $\mathrm{Zal}$ in Kuncuz province, said Samsulhaq Arinastar, a spokesman for the ant-Taliban alliance.

Both sides hesvily pounded each other's positions with artillery and shells,'githough Firiasfar' did not have ary cosulty fogres.-AP

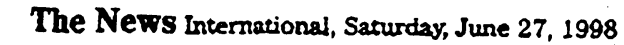 NGO paints grim picture of drug abuse in Afghanistan \\ By Ayesha Shaheen \\ lated area.}

PESHAWAR: Drug abuse in parts of northern Afghanistan has reached alarming proportions where 14,000 opium users have so far been reported at the three detoxification centres in Badakhshan province during the last one year.

This was stated by Qasim Zamani. director Nejat, a drug treatment and rehabilitation project of Orphan Refugees and Aid International while talking to The. News on the occasion of international day against drug abuse here on Friday. Zamani painted a grim picture of drug abuse in Afghanistan and said that in Zebak, Wakhan and Eshkashim, the border districts of Badakhshan, almost 60 to 70 per cent population consumes opium.

"It has become a family drug for them and in many cases the entire family becomes addict and the habit is practised from generation to generation," he added. He said usually an elder woman of the family places opium on burning coal and all the members both male and female gather around to consume the drug. Infants from the time of their birth. are made addicts. Mothers - give opium to infants to make them asleep to do their household chores," $\mathrm{Za}$. mani said.

This is a common practice among the carpet weavers in Afghanistan as well as in the refugee camps in Pak. istan where women have to work to make both ends meet. He said poppy was gromn in Muslim-dominated areas in the north but the stuff was mostly consumed in Ismaili popu-
According to a survey of the Nejat opium abuse was common almost in 20 per cent of the Ismailis and 10 percent of the Uzebak and Turkeman population.

Explaining various factors for drug addiction in the snow-bound parts of Afghanistan, member management board of directors Nejat, Jehanzeb Khan said, "it is one way of keeping themselves warm during harsh winters." He said that unemployment and non-availability of medical facilities in the border areas of the war shattered country were also one of the causes of drug abuse.

Zamani was, however, hopeful that the number of addicts was bound to decrease because Nejat was extending treatment to the whole of the addicted family instead of individuals. "By doing so they can motivate each other to give up use of drug and help in the rehabilitation process as well," informed Jehanzeb Khan.

While addressing the audience, Dr Toni Grosshauser, executive director Central Asia ORA said he was proud to announce that this was the only NGO working inside Afghanistan which extended help to all the communities above their ethnic lines. Dr. Toni said the work was started with the establishment of a four-bed centre in 1991 at Peshawar but now the area of its activities has been expanded.

He said two new projects called Huira and Dosti are being set up in Peshawar to have a contact with addicts and their families during the pre-treatment and reintegration phase of the programme. 


\section{Taliban to open women's vocational schools shortly News 980626} ISLAHIABAD: An executive member of the Afghan Women Association based in Germany, Shakira Nadi, who paid a visit to Kabul last week has said she held eallos with the Thiban who have assured her that girls rocatlonal insedtutions and other female schools will be opened shortly.

In an interview with Voice of Anerica (VQA), Stakira Nad said "the propaganda being done by foreign agencies about. Afghanistin, compelled her to visit $K a b u l$ and to see for herself the prevalent situation in Afghanistan." She said, "I saw there that female doctors and nurses are still worloing in women hospitals and ciries and the former lady ofi. cials who are presently sitting in Afghanistan are being psid manthly salivies regulariy."
Though the condition of women in the country is not good, but not so worse as depicted by loreign inedia", she remarived.

I held in-depth discusdons with the officials of the Ministry of Dducation and Training, in-charge of Anr Bll Marour directorate in Kabul and Secretary Public Heaith Mulla Stankrai and discussed with them matters concerning female educaton and women rights. To some er. tent I was convinced", she added.

Accorting to the report, one thing which was important that Tal. iban assired her that they will soon open 5 female schools, 22 vocational schools for women and nursing courses. They had also presented this plan to the United Nations, the report maintained.-APP

\section{The Nation . MONOAY. JUNE 29.1298.}

KABUL (AFP) - A woman and two youing boys were among four killed early. Sunday when a barrage of 10 heavy rockets slammed into Talibanheld. Kabul from frontlines north of the city.

The woman was walking along cirrying a bag and was hit in the neck by shrapnel, and the young boy was playing.' said Mohammad Yusiuf, a resident of a cluster of mud houses near the city's ctivilian-military airport.

Another young boy; also playing as he climbed a fruit tree; died on the way. to hospital, locals reported.

Hospital staff said one civilian died in hospital who had been admitted there with serious injuries $i$ while two suffering from light wiundis wörc dis-

charged after treatmont tack.

Two earlier Unifed Nations and In ternational Committce of the Red Cross (ICRC) nights had flown in and out of the triport early. Sunday, and were clcar of the area by the time the rockets hit:

Allithe residents and Taliban troops in the area, contacted: said they had counted a total of 10 rockets in the period between 10 am and $j 1: 30$ am period between 10 am and
(0530 GMT 10.0700 GMT).

\section{EU urges Taliban to stop poppy cultivation}

KABLL: A European Union mission expressing concern over growing export of drugs to Europe called Sunday for effective measures by the Taliban authorities to stop opium production in areas under their control.

The delegation of EU diplomats based in Islamabad complained that much of the opium grown in the Taliban-held two-thirds of Afghanistan ends up in Europe.

The mission led by British High Commissioner to Pakistan, David Dain, includes Dutch ambassador Joop Walkate, Austrian ambassador Waiter Howadt and the European Commission ambassador, Kurt Juul.

They arrived in Kabul on Saturday and were met by the Deputy Chairman of the Taliban Ruling Council Mulla Abdul Kabir and senior foreign ministry officials. "I raised the very important matter of drugs and opium production in Afghanistan during these meetings," Dain said.

He said the Taliban officials were receptive to his ideas but they cited economic problems in immediately abolishing poppy cultivation in the

In the city center the shockwaves earred by the 10 blasts believed to be charged affaires carrying France's : from either. Soviet-made Orogan or Yvarged affaires to Afghanistan. Jean- BM-21 rockets _wcre also clearly felt. Yves Berthiault, and senior Red Cross: : Residents said three had hit areas staff was cancelled following the at- country:

Neins 980622

Sources say 80 per cent of drugs seized in Europe originated from war ravaged Afghanistan where poppies grown in Taliban territory and areas controlled by the opposition Northern Alliance. Dain said the mission will visit northern Sheberghan town for similar talks with leaders of the anti-Taliban alliance. He said the visit was also aimed at persuading the warring Afghan sides to resume the peace process deadlocked since talks in Islamabad in April.

"Our wish is to see the talks resumed," he said stressing the visit was to assert a more active involvement of the EU in the United Nations sponsored peace endeavours in the country where thousands of people have died in years of civil war.

Dain, whose country is current EU president, said he also discussed with Taliban authorities the issues of human rights and women's rights, particularly education for Afghan girls. It was important for the Euro pean public opinion that somethine should be seen to change in this re spect; he said without giving de tails. - AFP

\section{Taliban order doctors not to treat unaccompanied women}

\section{News 580626 Widows most seriously affected}

KABCL: Doctors working in Taliban-held Afghanistan were ordered Thursday to deny treatment to women not accompanied by a close male relative, state-run Radio Shariat announced.

The department of regulation and inspection of the public health ministry announces to all doctors and medical personnel not to examine and treat women without their legal Mahram present," Radio Shariat sald.

The ruling is the latest in a long serles of tough measures aimed at reforming public health structures, in which the puritanical Muslim militia has attempted to minimise coneact between men and women. it is aiso likely to pose serious problems for the Alghan capital's estimated 30,000 widows, many of whom have no male relatives to accompany them.

All public hospitals have alreacty been tightly segregated and are subject to regular inspections by religious police squads from the ministry for the fostering of virtue and prevention of vice.

It also comes amid a crisis of foreign ald agency medical projects in the Afghan capital, many of which have been suspended following militia threats to locally recruited fernale stafi.

The miltia antl-vice ministry last month banned women from working for foreign aid groups unless. they can show identity cards signied by the millitia.

So far no cards have been ts sued. Asghan ferthale staft hisve also been barred from workding outstde approved health structures, shutting down a number of home-visis midwife and widow's health schemes.

The ruiling is a further challenge to 3 memorandum of understanding between the United Nations and the Taliban, signed last month amid a storm of critlcism in which the UN was aceused of ignoring universal principles of gender rights.

The UN took the controversial step of accepting that female access to health in the Taliban-held two thirds of Afghanistan will need to be gractual.

The world body also recognised that even a gradual increase in fe male access to health prould be "challenging" due to "economic difficuities and cultural traditions. AFP 